\title{
CIVIL-KATONAI KAPCSOLATOK ÉS A HADERÖ DEMOKRATIKUS KONTROLLJA A FÜGGETLEN SZLOVÉNIÁBAN ÉS HORVÁTORSZÁGBAN (1991-2011)
}

DOKTORI ÉRTEKEZÉS

Témavezető: Gallai Sándor, PhD

Harangozó Dániel

Budapest, 2018 
Harangozó Dániel

Civil-katonai kapcsolatok és a haderő demokratikus kontrollja a független Szlovéniában és Horvátországban (1991-2011) 
Politikatudományi Intézet

Témavezető:

Gallai Sándor, $\mathrm{PhD}$

(C) Harangozó Dániel 


\author{
Budapesti Corvinus Egyetem \\ Politikatudományi Doktori Iskola
}

Civil-katonai kapcsolatok és a haderő demokratikus kontrollja a független Szlovéniában és

Horvátországban (1991-2011)

Doktori értekezés

Harangozó Dániel

Budapest, 2018 


\section{Tartalomjegyzék}

1. Bevezetés ....................................................................................................................................... 4

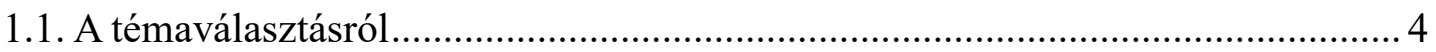

1.2. A dolgozat kutatási kérdései és a vizsgált magyarázó tényezők ........................ 6

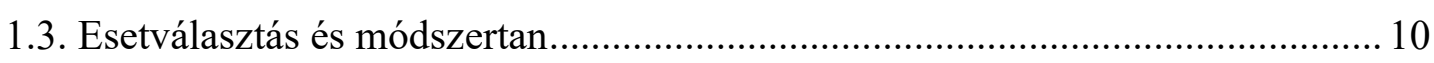

1.4. A dolgozat felépítése ................................................................................ 11

2. Civil-katonai kapesolatok az elmélet tükrében .................................................. 13

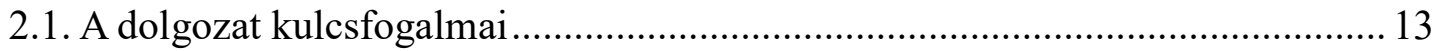

2.2. Civil-katonai kapcsolatok az elmélet tükrében: bevezető gondolatok ................ 18

2.3. A civil-katonai kapcsolatok klasszikus elméletei .............................................. 19

2.3.1. Samuel P. Huntington: „professzionalizmus” és „objektív civil kontroll” ...... 19

2.3.2. Morris Janowitz és a ,,szociológiai” megközelítés.......................................... 24

2.3.3. Samuel E. Finer: A hadsereg politikai beavatkozásának problémája............... 27

2.4. A civil-katonai kapcsolatok kortárs elméletei .................................................. 33

3. Civil-katonai kapcsolatok a szovjet típusú pártállami rendszerekben ............49

3.1. A civil-katonai kapcsolatok általános jellemzői a pártállami rendszerekben...... 49

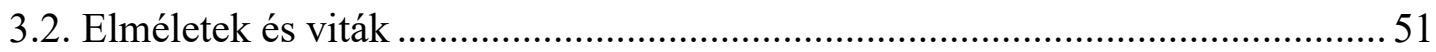

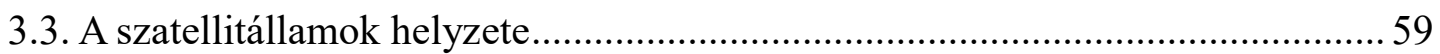

4. Civil-katonai kapcsolatok a titói Jugoszláviában (1945-1991)........................ 61

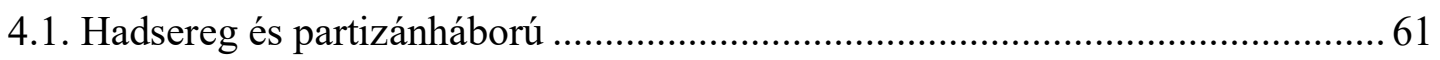

4.2. A Jugoszláv Néphadsereg és a jugoszláv rendszer eredete (1945-1961) ............ 64

4.3. Professzionalizáció és érdekcsoport-politika (1961-1971) .................................66

4.4. Az 1971-es válság és a hadsereg "politikai intézményesítése" (1971-1980) ...... 69

4.5. A Tito utáni időszak (1980-1987) .................................................................... 73

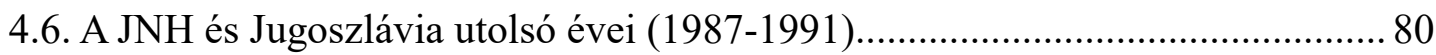

5. A fegyveres erők szerepe a posztkommunista átmenetben..............................98

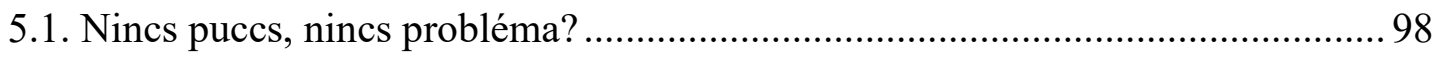

5.2. A fegyveres erők és a pártállami rendszerek felbomlása .................................. 99

5.3. Az átmenet politikai kihívásai a védelmi szférában....................................... 101

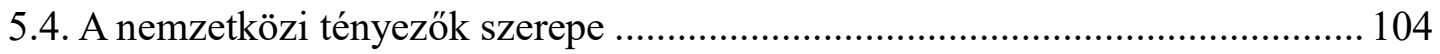

5.5. Fegyveres erők a posztkommunista átmenetben: összegző gondolatok ........... 109 
6. Szlovénia: „Jugoszláviából Európába”?

6.1. A szlovéniai rendszerváltás és az önálló szlovén haderő létrejötte (1990-91) .. 111

6.2. Államépítés és biztonságpolitikai „útkeresés” (1991-1994) ............................ 119

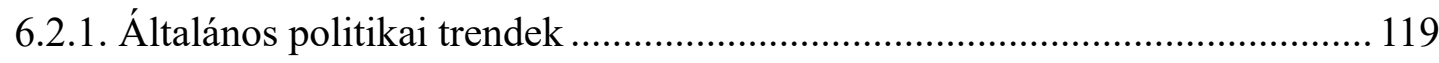

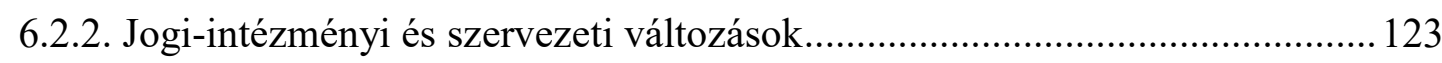

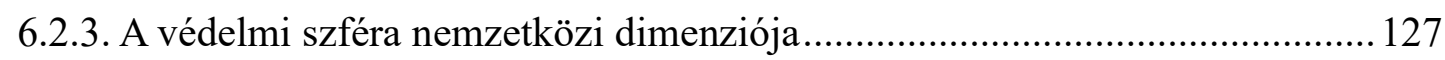

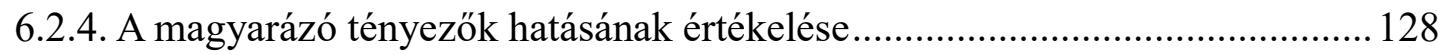

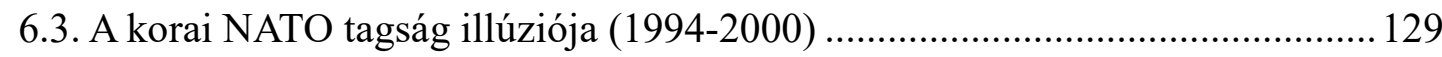

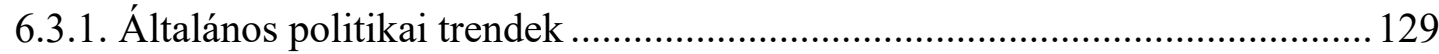

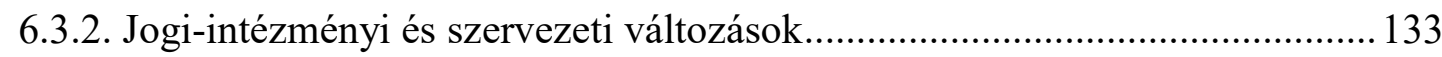

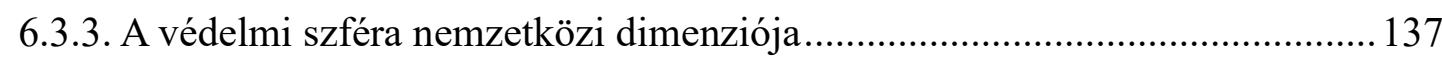

6.3.4. A magyarázó tényezők hatásának értékelése................................................. 140

6.4. "Szakértői kormányzás" a védelempolitikában és NATO- csatlakozás (2000-

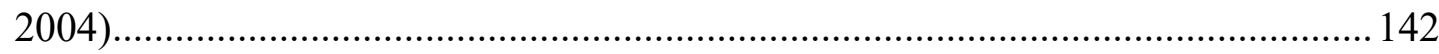

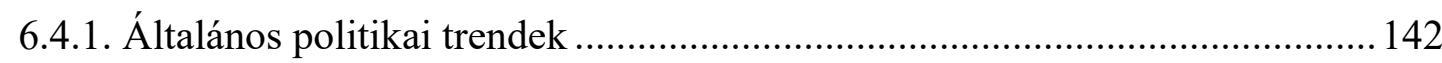

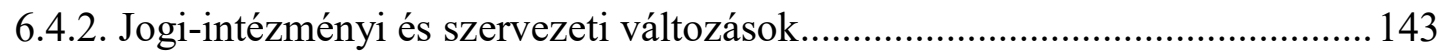

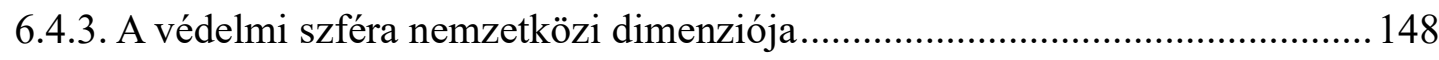

6.4.4. A magyarázó tényezők hatásának értékelése................................................. 151

6.5. Szlovénia a NATO-tagság első éveiben (2004-2011) ...................................... 153

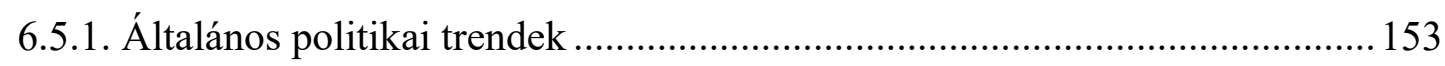

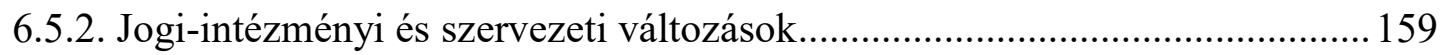

6.5.3. A védelmi szféra nemzetközi dimenziója................................................... 162

6.5.4. A magyarázó tényezők hatásának értékelése ................................................ 165

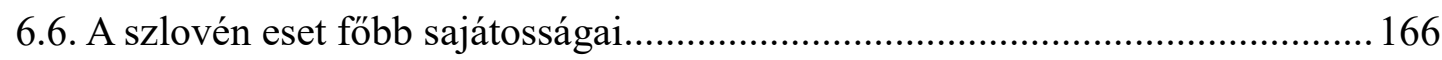

7. Horvátország: Demokrácia - ütközetben eltünt? ...........................................172

7.1. A horvátországi rendszerváltás és az önálló horvát hadsereg létrejötte ............. 172

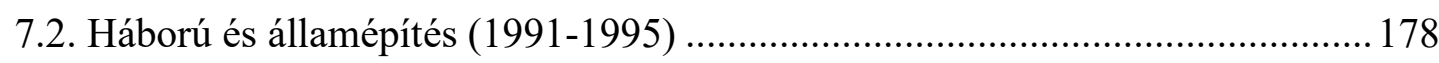

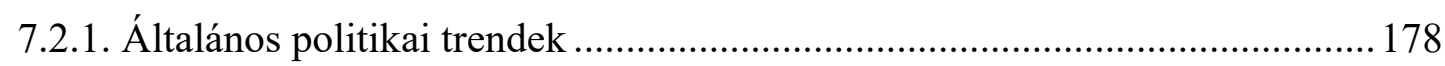

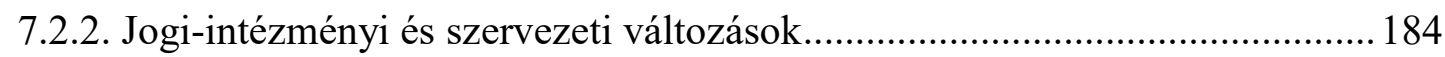

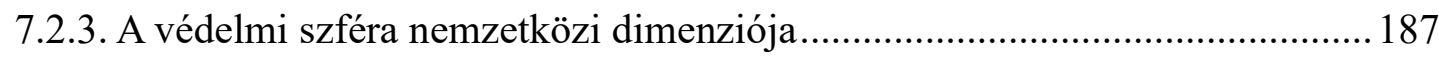

7.2.4. A magyarázó tényezők hatásának értékelése .............................................. 189

7.3. Fegyveres erők és autoriter hatalomgyakorlás (1995-1999) ............................ 192

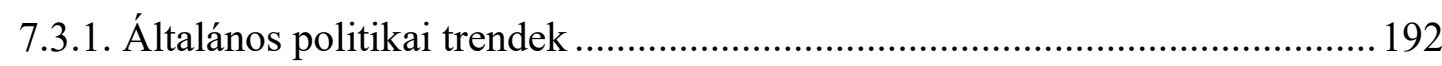


7.3.2. Jogi-intézményi és szervezeti változások

7.3.3. A védelmi szféra nemzetközi dimenziója.

7.3.4. A magyarázó tényezők hatásának értékelése............................................. 200

7.4. A civil-katonai kapcsolatok demokratizálása Tudjman után (2000-2003) ........ 202

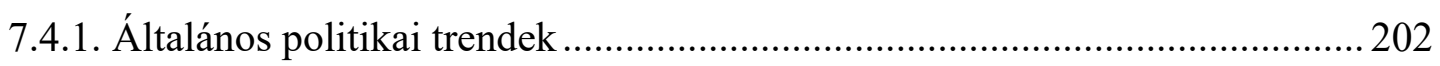

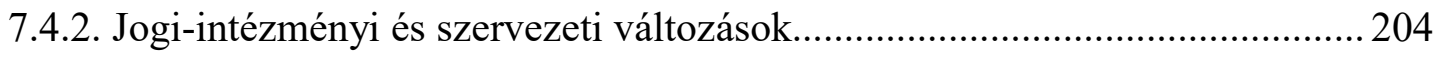

7.4.3. A védelmi szféra nemzetközi dimenziója.................................................. 211

7.4.4. A magyarázó tényezők hatásának értékelése............................................. 215

7.5. Civil-katonai kapcsolatok és euroatlanti integráció a „reform-HDZ” kormányzat

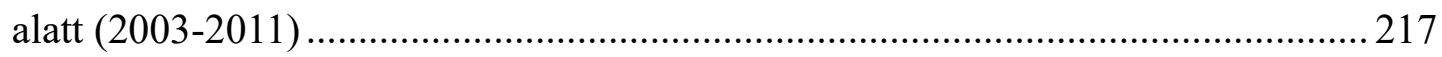

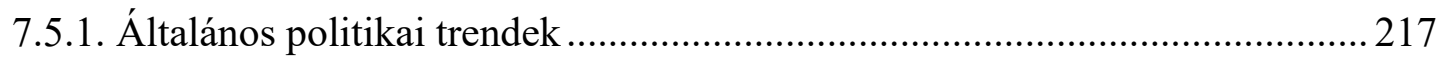

7.5.2. Jogi-intézményi és szervezeti változások.................................................. 220

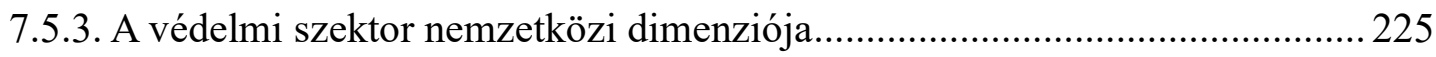

7.5.4. A magyarázó tényezők hatásának értékelése............................................. 230

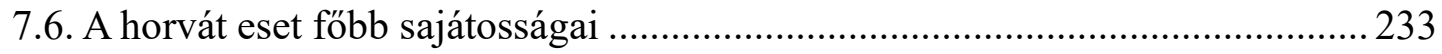

8. Összegzés és következtetések........................................................................ 240

8.1. A szlovén és horvát eset hasonlóságai és különbségei ...................................2240

8.2. A legfontosabb kutatási eredmények összegzése ............................................ 245

I. függelék: A kutatás során készített interjúk listája ...................................... 248

Irodalomjegyzék ..........................................................................................249 


\section{$\underline{\text { 1. Bevezetés }}$}

\subsection{A témaválasztásról}

A hadsereg feletti politikai ellenőrzés a politika világának egyik legrégebbi problémája, a "ki örzi az örzőket?” kérdése azonban a modern korban is releváns és aktuális. A fegyveres erők és a politika viszonya fontos szerepet játszott a XX. század második felében lezajlott demokratikus átalakulások, így a dél-európai és a latin-amerikai átmenetek során is (Agüero 1995, 3-6). Azonban míg az említett két régióban a hadsereg megkerülhetetlen szereplő volt a demokráciába történő átmenet folyamatában, addig a közép- és kelet-európai pártállami rendszerek felbomlása során a fegyveres erők szerepe passzívnak minősíthető (Barany 1993, 155-157). A dél-európai és latin-amerikai autoriter rendszerektől eltérően a pártállami rendszerekben a hadsereg nem volt önálló politikai szereplő, valamint ezen rezsimek fenntartása (és az ehhez szükséges belső represszió) szempontjából is korlátozott szerep hárult rájuk (Barany 1993, 150-153, Perlmutter és LeoGrande 1982, 780).

Ez ugyanakkor nem jelenti azt, hogy a demokratikus rendszer kiépítése e régióban ne járt volna sajátos kihívásokkal a hadsereg és a politika viszonya terén. A pártállami rendszerekben, noha civil kontroll alatt állt a hadsereg, ez a kontroll nem volt demokratikus: a hadsereg feladata a párt hatalmának védelme volt, melyet a fegyveres erőkben az állampárt intézményes jelenléte is kifejezett (Barany 1993, 1011). Mint Bárány D. Zoltán megállapította, míg a katonai uralom után demokratizálódó rendszereknél a fö kihívás a „politika demilitarizálása”, a pártállami rendszert hátrahagyó országok esetében az átalakulás fó feladata a „hadsereg depolitizálása” volt (Barany 2012, 222). A posztkommunista átalakuló országok mindegyikében jelentkező kihívások az újonnan létrejövő államokban - így a jugoszláv utódállamokban is - kiegészültek az államépítés és ezen keresztül a hadseregépítés problémáival is (Barany 2012, 225-226).

Doktori értekezésemben két jugoszláv utódállam, Szlovénia és Horvátország esetében vizsgálom a haderő feletti demokratikus politikai kontroll kiépítését, illetve a civil-katonai kapcsolatok alakulását független államiságuk első 20 éve során. ${ }^{1}$

\footnotetext{
${ }^{1}$ A dolgozat kutatási előzményét képezik a szerző korábbi, a civil-katonai kapcsolatok és a horvát euroatlanti integráció témájában folytatott kutatásai, valamint szakmai együttmüködése a Ljubljanai Egyetem Társadalomtudományi Karán működő Védelmi Kutatások Központjával (ORC).
} 
A dolgozat fogalmi kerete az államépítés egyik összetevője, a hadseregépítés folyamata, és ennek összefüggése az előbbi, általam vizsgált két fö kérdéssel. A dolgozat célja továbbá azon magyarázó tényezők értékelése, amelyek a civil-katonai kapcsolatokra, valamint a haderő demokratikus kontrolljára hatást gyakoroltak az elemzést tárgyát képező időszak során. A dolgozat által vizsgált időbeli periódust a két ország független állami létének első húsz évében határoztam meg, melynek záró éve, 2011, egyben választási év is volt mind Szlovéniában, mind pedig Horvátországban. A függetlenség elnyerését megelőző eseményekre több helyütt röviden utalok, amennyiben ezek a téma szempontjából relevánsak. A dolgozat alkalmazásában "fegyveres erők" illetve "hadsereg" alatt a reguláris haderőt értem, a paramilitáris szervezetekre, fegyveres csoportokra a vizsgálat nem terjed ki. Szintén nem vizsgálom az állami erőszak-monopólium gyakorlásával megbízott más szervezeteket, így a rendőrséget, határőrséget, illetve a nemzetbiztonsági szolgálatokat sem. Jelen értekezésnek továbbá nem célja a délszláv háborúk, ezen belül a horvátországi és szlovéniai konfliktus részletes eseménytörténetének ismertetése sem, a két országban zajló fegyveres cselekményekre csak röviden, és csak abban az esetben utalok, amennyiben az a téma szempontjából releváns.

A dolgozat egyszerre használja a politikatudományi, a hadtudományi és a nemzetközi kapcsolatok területéről származó megközelítéseket a téma vizsgálatában, összhangban a civil-katonai kapcsolatok, mint kutatási terület interdiszciplináris jellegével (Olmeda 2013, 62-63). Az értekezés újdonságát képezi, hogy a civilkatonai kapcsolatok és a haderő demokratikus kontrolljának kérdéseit összehasonlító keretben, illetve több magyarázó tényező bevonásával vizsgálja. A külső tényezők esetében a vizsgálatom nem korlátozódik a nemzetközi szervezetek befolyására, hanem figyelembe veszi a fegyveres konfliktus és a biztonsági fenyegetés-percepciók hatását is. A nemzetközi szakirodalomban relatíve kevés összehasonlító elemzés készül a civil-katonai kapcsolatok témájában (Olmeda 2013, 68), a hazai szakirodalomban pedig általánosságban kevés figyelmet kapnak mind a civil-katonai kapcsolatok és a haderő demokratikus irányítása, mind pedig a szomszédos jugoszláv utódállamok katonai, védelmi kérdései. A dolgozat szakpolitikai (policy) relevanciáját az adja, hogy a két vizsgált állam az euroatlanti integráció és a haderőátalakítás terén szerzett tapasztalatai a posztjugoszláv térség más államai által is hasznosíthatóak. 


\subsection{A dolgozat kutatási kérdései és a vizsgált magyarázó tényezők}

A kutatás megtervezése során a vizsgált országokkal kapcsolatban négy kutatási kérdést vetettem fel:

1./ Hogyan befolyásolta a jugoszláv történelmi-politikai örökség a hadseregépítést, mint az államépítés egy konkrét területét?

2./ Hogyan hatott a civil-katonai kapcsolatokra, valamint a haderő demokratikus kontrolljára a két vizsgált országban lezajlott fegyveres konfliktusok eltérő időtartama és intenzitása?

3./ Hogyan befolyásolta a civil-katonai kapcsolatok alakulását és a haderő demokratikus kontrolljának kiépítését a politikai rezsimek 1990-es években eltérő jellege (azaz a demokrácia-deficit különböző mértéke)?

4./ Hogyan hatott a civil-katonai kapcsolatokra és a védelmi szektor reformjára az euroatlanti integráció eltérő perspektívája a két ország esetében?

Építve a fenti kutatási kérdésekre, a vonatkozó szakirodalom áttekintése nyomán négy magyarázó tényezőt tartok relevánsnak.

1./ A történelmi örökség szerepe: a korábbi történelmi tapasztalatok (vagy azok általánosan elterjedt percepciója az adott országban) jelentős hatást gyakorolhatnak a biztonsági és védelmi terület politikai és szakpolitikai folyamataira és ezen keresztül a civil-katonai kapcsolatok kérdésére is. Szerepet játszhatnak az önálló állami tradíciók (meglétük vagy hiányuk), az adott nép vagy nemzet korábbi katonai tradíciói vagy éppen a fegyveres erőkkel kapcsolatos korábbi társadalmi attitüdök (Vankovska és Wiberg 2003, 39-40). Cottey és munkatársai $(2005,11)$, Bárány D. Zoltán (1997, 21-22), Daniel N. Nelson (2002b, 427-428), Edmunds, Forster, és Cottey $(2003,249)$ és Szabó János $(2005,64)$ szerint a fegyveres erők szerepét a posztkommunista átmenetben és konszolidációban befolyásolhatja a kommunista ${ }^{2}$ és prekommunista időszak történelmi tapasztalata is. Szlovénia és Horvátország esetében - a korábbi önálló államiság irrelevanciája (é. hiánya, illetve rövidsége) miatt - elsődlegesen a jugoszláv történelmi-politikai örökség szerepét vizsgálom.

\footnotetext{
${ }^{2}$ A következő fejezetekben az egyszerűség kedvéért a nyugati szakirodalommal összhangban álló „kommunizmus” kifejezést fogom használni a Szovjetunióban, annak szatellitállamaiban, valamint az egykori Jugoszláviában 1989-91 előtti évtizdekben létezett politikai, gazdasági és társadalmi berendezkedés leírására. Jelen értekezésben ez a terminus szinonimaként tekintendő a magyar nyelvü szakirodalomban elterjedtebb „szocializmus” illetve ,államszocializmus” kifejezéssel.
} 
E tekintetben különösen a titói éra civil-katonai kapcsolatai, valamint az 1968 utáni jugoszláv katonai doktrína, az ún. össznépi védelem érdemelnek figyelmet.

2./ A fegyveres konfliktus és a fenyegetettség-percepciók hatása: a fegyveres konfliktus és a fegyveres erők civil kontrollja közötti összefüggés vizsgálatára a szakirodalomban klasszikus példák is megtalálhatóak. Harold Lasswell (1941) szerint akkor gyengül a fegyveres erők feletti civil kontroll, ha az állam jelentős külső fenyegetésnek van kitéve. Ez az úgynevezett „kaszárnyaállam” hipotézise. Stanislav Andreski (1954) ezzel ellentétben azon az állásponton van, hogy a külső fenyegetés hiánya, és a hadsereg ebből következő „tétlensége” vezet a civil kontroll meggyengüléséhez (Desch 1996, 12-13 és Desch 1999, 1-2). Michael C. Desch strukturális realista modellje a külső és belső fenyegetéseket, illetve azok civil kontrollra gyakorolt hatását elkülönítve kezeli (Desch 1999, 11-13).

3./ A belső politikai folyamatok hatása: a haderő demokratikus kontrollja és a demokratikus politikai berendezkedés megléte szükségképpen feltételezik egymást, mivel a demokratikus berendezkedés müködéséhez szükséges az állami eröszakmonopólium gyakorlásával megbízott szervezetek demokratikus kontrollja is (Vankovska és Wiberg 2003, 3-4, Cottey, Edmunds és Forster 2002c, 262-263). Ugyanakkor még abban az esetben is, ha a demokratikus kontroll intézményi és politikai feltételei biztosítottak, problémát jelenthet a fegyveres erők ,átpolitizálása”, azaz politikusok általi, pártpolitikai vitákba történő bevonása. Ez a jelenség eredhet a politikusok, így például az államfő és a kormány közötti hatásköri vitákból vagy nézeteltérésekből, vagy a politikai vezetök azon törekvéséböl, hogy a katonai vezetést saját „politikai hátországuk” részévé tegyék (Huntington 1996, 11, Born et al 2006b, 244-246, 253, Bland 1995). Ezen tényező esetében vizsgáltam a politikai berendezkedés és a hatalomgyakorlás demokratikus vagy autoriter jellegét, valamint azt, hogy tapasztalható volt-e a biztonsági és védelmi kérdések ,átpolitizálódása”, azaz váltak e ezen kérdések jelentős politikai-ideológiai nézeteltérések, viták tárgyává.

4./ A nemzetközi szereplök és szervezetek szerepe a vizsgált folyamatokban többféleképpen is értelmezhető. A kondicionalitás politikáját a taggá válás folyamatában mind az Európai Unió, mind pedig a NATO alkalmazta, különösen az ún. prekondicionalitás formájában. Ebben az esetben az érintett államnak megadott feltételeket kell teljesítenie annak érdekében, hogy a szóban forgó szervezet (EU vagy NATO) tagjává válhasson (Edmunds 2003b, 139-140, Simunovic 2015, 176- 
180). Ellentétben az Európai Unióval, melynek csatlakozási követelményei részletesen kidolgozottak, és az egyes bővítési körök során esetenként változtak és kiegészültek (a szlovén és horvát EU-csatlakozás összehasonlító elemzését lásd pl. Bojinovic-Fenko és Urlic 2015), a NATO által támasztott feltételek inkább általános jellegűek (lásd NATO 1995), noha az 1999 utáni bővítési körök során ezeket is több tekintetben pontosították (Edmunds 2003, 6-7, 53-54, Simunovic 2015, 176-177,179180, Melnykovska és Schweickert 2010, 7). A közvetlen vagy direkt kondicionalitás a prekondicionalitástól annyiban különbözik, hogy a feltételek meghatározói szankciót vagy következményt helyeznek kilátásba arra az esetre, ha a feltételeket nem teljesítik (Edmunds 2007, 42-43). A két vizsgált ország közül a nemzetközi közösség csak Horvátország esetében alkalmazta a kondicionalitás ezen formáját, a volt Jugoszlávia területén elkövetett bünöket vizsgáló hágai törvényszékkel (ICTY) való együttmüködés kikényszerítése érdekében (Edmunds 2003, 61-63, Edmunds 2007, 43).

A nemzetközi kapcsolatok elméletének szociál-konstruktivista irányzatát képviselö Alexandra Gheciu (2005, 2005b) szerint a nemzetközi biztonság szervezetek, mindenekelőtt a NATO, a posztkommunista régióban nemzetközi szocializációs funkciót is elláttak a konkrét politikai feltételesség alkalmazásán túlmenően.

Kutatásom keretében a NATO és esetenként az Európai Unió befolyását illetően azt igyekeztem feltárni, hogy e két szervezet mennyire volt képes hatást gyakorolni a katonai-védelmi szférán belüli döntéshozatalra, illetve szakpolitika-formálásra, különösen a témám szempontjából releváns területen. Vélelmezhető relevanciájuk miatt két esetben (a jugoszláv utódállamokat érintő ENSZ-fegyverembargó és Horvátország kétoldalú védelmi együttmüködési kapcsolatai az 1990-es években) a fenti két szervezeten kívüli nemzetközi szereplők hatását is vizsgáltam.

A magyarázó tényezők hatását egy négyfokú skálán értékeltem mindkét ország és valamennyi periódus esetében. Ennek során azt vettem figyelembe, hogy az adott tényező az adott perióduson belül a civil-katonai kapcsolatok főbb jellegzetességei szempontjából mennyire gyakorolt hatást.

- A hatás ,elhanyagolható”, ha a tényező a vizsgált periódusban nem fejtett ki hatást, vagy a hatása a téma szempontjából irreleváns volt.

- A hatást „,kimutathatónak” tekintem, ha a tényező gyakorolt hatást az általam vizsgált folyamatokra, de ez nem volt jelentős. 
- Ha a tényező jelentősen befolyásolta az általam vizsgált folyamatokat, de nem ez volt a vizsgált periódusban az elsődleges magyarázó tényező, akkor a hatást „érdeminek” minősítem.

- Végezetül, a hatás „meghatározó”, ha az adott periódusban a vizsgált folyamatok az adott tényezőhöz igazodtak, vagy elsődlegesen az adott tényező által magyarázhatók.

Mindkét vizsgált ország esetében az elemzés megkönnyítése érdekében a dolgozat tárgyát képező húsz éves időszakot négy többéves periódusra bontottam. A periódushatárokat részben a vizsgálat időbeli kezdő és végpontja (1991 és 2011), részben pedig választási évek, a téma szempontjából jelentősebb belpolitikai események, a vizsgált országokat érintő konfliktusok kezdete és lezárása (így a horvátországi háború vége 1995-ben), illetve a NATO-csatlakozás időpontja alkotják.

Az országtanulmányokon belüli egyes periódusok tartalmi és szerkezeti felépítésének kialakításakor támaszkodtam Timothy Edmunds (2007, 27-28) korábbi, SzerbiaMontenegró és Horvátország tárgyában végzett összehasonlító elemzésére, ahol a szerző a védelmi reformok elemzésekor a politikai, a szervezeti és a nemzetközi szintet különítette el.

$\mathrm{Az}$ „általános politikai trendek” címü alfejezetben azt vizsgálom, hogy melyek voltak az adott időszak föbb szakpolitikai problémái, voltak-e az időszakban a védelmi szférát érintő jelentősebb politikai viták vagy botrányok, valamint, hogy mekkora volt a szakpolitikai folytonosság az időszakon belül.

A „jogi-intézményi, és szervezeti változások” címü alfejezetben arra keresem a választ, hogy hogyan alakultak a terület szempontjából releváns jogi-intézményi keretek, milyen volt az adott időszakban az általános védelmi koncepció, valamint, hogy milyen lépések történnek a haderő reformja terén és mi motiválta azokat.

Végezetül a „védelmi szféra nemzetközi dimenziója” című alfejezet fő kérdései arra irányulnak, hogy az adott időszakban milyen mértékü volt a hadsereg nemzetközi szerepvállalása - elsődlegesen béketámogató müveletek révén -, jelen volt-e és ha igen, mennyire volt sikeres a kormányzat euroatlanti integrációra irányuló ambíciója, illetve, hogy milyen befolyást gyakoroltak a nemzetközi szervezetek (elsődlegesen a NATO és az Európai Unió) a védelmi politika-formálásra. 


\subsection{Esetválasztás és módszertan}

A disszertáció által vizsgált két ország számos közös jellemzővel rendelkezik, mely indokolhatja, miért e két államot választottam az országtanulmányok tárgyául. 1./ Méretüket, lakosságszámukat és a nemzetközi rendszerben elfoglalt szerepüket tekintve (Keohane 1969, Rickli 2008) mind a két állam ún. kisállamnak tekinthető.

2./ Szlovénia és Horvátország Jugoszlávia felbomlását megelőzően a jugoszláv állam két gazdaságilag legfejlettebb tagköztársasága volt (noha a szlovén egy före jutó GDP jelentősen meghaladta a horvátot), és a politikai rendszerváltás során hasonló célokat (függetlenedés, euroatlanti integráció) tüztek ki.

3./ Mindkét állam új államnak tekinthető. Horvátországnak igen csekély független állami tradíciói voltak, míg Szlovénia esetében ezek teljességgel hiányoztak. A többi állami intézményhez hasonlóan a fegyveres erőket is újonnan kellett a két államnak kiépítenie.

4./ Eltérően például Szlovákiától, mind Szlovénia mind pedig Horvátország függetlenné válását fegyveres konfliktus kísérte, mely azonban eltérő időtartamú és intenzitású volt. Emiatt a formálódó szlovén és horvát hadsereg egyfajta “nemzetépítő" szerepet is játszott (Edmunds 2006, 1073-1074).

5./ A jugoszláv történelmi örökség több szempontból is hatást gyakorolt a két ország további fejlödésére a katonai és védelmi szféra területén is. Egyfelöl a közös történelmi tapasztalat mind a későbbi szlovén mind pedig a horvát katonai, stratégiai kultúrában éreztette hatását, ugyanakkor a Jugoszláv Néphadsereg mindkét 1991 előtti tagköztársaságban (Szlovéniában már az 1980-as évek során, Horvátországban pedig legkésőbb 1990-91-ben) fokozatosan elvesztette legitimitását és a szövetségi haderővel való szembenállás a függetlenségi mozgalom egyik "katalizátorává" is vált (Bebler 1993, Malesic és Jelusic 2005).

A dolgozat módszertani szempontból két célkitüzéssel rendelkezik. Egyfelöl, fel kívánom tárni a civil-katonai kapcsolatok fö tendenciáinak alakulását, illetve a haderő feletti demokratikus kontroll kiépítését a két vizsgált országban. Ebben a tekintetben a kutatás idiografikus vagy ateoretikus jellegü (Lijphart 1971). Másodsorban, vizsgálni kívánom a kutatásba bevont négy magyarázó tényező hatását a civil-katonai kapcsolatok, illetve a haderő feletti demokratikus kontroll területén. Ily módon tehát a kutatás magyarázattal is kíván szolgálni e területek politikaiszakpolitikai folyamatainak mozgatórugóit illetően. 
Kutatásom a kvalitatív, összehasonlító esettanulmányok közé sorolható, melynek fö módszereként a strukturált, fókuszált összehasonlítást (George és Bennett 2005, 6773), és a folyamat-elemzést (process tracing) (Beach és Pedersen 2013) használom.

A dolgozatot megalapozó kutatás során feltártam a téma angol és magyar nyelvü szakirodalmát, valamint külföldi kutatóként beszerezhető szlovén és horvát nyelvü forrásokat $^{3}$ is bevontam a vizsgálatba. A másodlagos forrásokat a téma szempontjából releváns jogszabályok, egyéb jogi aktusok (rendeletek, utasítások), illetve minisztériumi dokumentumok (mint például éves jelentések) feldolgozásával egészítettem ki. Az irodalomkutatás mellett több interjút készítettem biztonság- és védelempolitikai szakértőkkel, valamint Szlovénia két korábbi honvédelmi miniszterével is. A kutatás során készített interjúk listáját az I. függelék tartalmazza.

\subsection{A dolgozat felépítése}

A bevezető fejezetet követően, melyben a dolgozat témaválasztása mellett annak módszertani kérdéseit is tárgyalom, az értekezés második fejezetében előbb meghatározom a dolgozat kulcsfogalmait, majd bemutatom azon klasszikus és kortárs elméleteket, melyek a civil-katonai kapcsolatok magyarázatára irányulnak. Mint látni fogjuk, a civil-katonai kapcsolatokkal foglalkozó elméletek többsége a fejlett demokráciák politikai, társadalmi viszonyait vette és veszi alapul. Emiatt szükségesnek tartottam külön bemutatni a civil-katonai kapcsolatok sajátos elméleti problémáit a pártállami rendszerekben, valamint ezen terület sajátos kihívásait a posztkommunista átmenet során. A harmadik fejezetben előbb a szovjet típusú pártállami rendszerek civil-katonai kapcsolataira vonatkozó elméleti magyarázatokat vizsgálom meg, majd a negyedik fejezetben részletesen bemutatom a jugoszláv modell sajátosságait a civil-katonai kapcsolatok szempontjából. A jugoszláv modell részletesebb vizsgálatát nem csupán a szovjettől való különbözősége miatt tartom indokoltnak, hanem azért is, mert a jugoszláv örökség több ponton jelentős hatást gyakorolt az önálló szlovén és horvát hadseregre és a tágabb védelmi szférára is. Végezetül, az ötödik fejezetben a posztkommunista átmenet fó kihívásait tekintem át a vizsgált területen.

\footnotetext{
${ }^{3}$ A kutatásomat befolyásolta, hogy a „stratégiai közösség”, azaz a biztonsági, védelmi kérdésekkel foglalkozó kutatók, szakértők köre Horvátországban szükebb, mint Szlovéniában. Lásd pl. Domjancic 2015, 170-171, Tatalovic 2010, 18-19.
} 
Noha időben túlmutat a szüken vett demokratikus átmenet időszakán, ebben a fejezetben tárgyalom röviden a nemzetközi szervezetek (főként a NATO) hatását a civil-katonai kapcsolatokra és a haderő demokratikus kontrolljának kialakítására a régió országaiban.

A vizsgálódásaim tárgyát képező két országról szóló esettanulmányok azonos felépítést követnek. Mindkét ország esetében előbb vizsgálom a független haderő létrejöttének körülményeit, az adott országban lezajló rendszerváltozással összefüggésben (jellemzően 1990 és 1991 év során), melyet a fentebb bevezetett periodizáció szerinti, azonos szerkezetü alfejezetek követnek. Mindkét országtanulmányt az adott országra vonatkozó megállapításokat összegző rövid konklúzió zárja. Az értekezés utolsó fejezetében összegzem a kutatás főbb következtetéseit, és a két országra vonatkozó összehasonlító elemzés eredményeit. 


\section{$\underline{\text { 2. Civil-katonai kapcsolatok az elmélet tükrében }}$}

\subsection{A dolgozat kulcsfogalmai}

A civil-katonai kapcsolatokra vonatkozó elméleti magyarázatok, modellek áttekintése előtt szükségesnek tartom röviden megvizsgálni a dolgozat kulcsfogalmait, a civil-katonai kapcsolatokat, illetve a haderő civil és demokratikus kontrollját, valamint a Peter D. Feaver $(2006,77)$ által "civil-katonai ellentétként" azonosított jelenséget.

A "civil" és a "katonai" szféra, mint a civil-katonai kapcsolatok két "résztvevője" tekintetében a szakirodalomban számos definíció létezik (Lásd pl. Bland 2001, 532, Nelson 2002, 160-163). Lényeges megemlíteni, hogy jelen esetben a "civil", "civil szféra" kifejezést eltérően használom, mint a politikatudományban általában, tehát nem az államtól elkülönült "civil társadalmat" értem alatta, hanem alapvetően "nem katonai"-ként határozható meg e fogalom jelentése. A dolgozatban a „civil” szféra fogalmát általában a politikai vezetésre korlátozom, azonban az esettanulmányok elkészítése során, amennyiben releváns, alkalmanként a politikai vezetésen kívüli társadalmi csoportokat, szervezeteket (az akadémiai szférát, médiát, érdekképviseleteket stb.) is bevonom az elemzésbe. A „hadsereg” fogalmát szintén leszükítő értelemben használom: vizsgálatomat a reguláris hadseregre korlátozom, valamint a politikai vezetéssel általában kapcsolatba kerülő katonai vezetést és fötiszti kart állítom a vizsgálat középpontjába. Nem vizsgálom tehát az állami erőszak-monopólium gyakorlására feljogosított más fegyveres szervezeteket (rendőrség, határőrség, csendőrség stb.), valamint az Edmunds (2007) által a „biztonsági szektor” részeként azonosított titkosszolgálatokat sem. A reguláris hadsereg fogalmát a két esettanulmány elkészítése során a vizsgált országok vonatkozó jogszabályai alapján fogom lehatárolni. Ez a definíció közel áll Nelson (2002, 161) "szük", vagy "leszükítő" fogalomértelmezéséhez.

A fentebb kifejtett gondolatmenetet folytatva, a civil-katonai kapcsolatok fogalma attól a pillanattól kezdve válik értelmezhetővé, hogy az adott társadalomban egymástól elhatárolható „civil” és „katonai” szféra létezik. Ekkortól beszélhetünk a Feaver (1996) által „civil-katonai ellentétként” azonosított jelenségről is. A problematika lényege viszonylag egyszerü: a társadalmi munkamegosztás kialakulása folytán szükség volt egy intézményre, mely a politikai közösség számára 
szükséges biztonsági, védelmi feladatokat látja el, de az állami erőszak-monopólium (vagy egy részének) rá ruházását követően joggal merül fel a kérdés, hogy miként biztosítható, hogy az erre feljogosítottak ne éljenek vissza ezekkel az eszközökkel (Feaver 1996, 150-152). Más szavakkal: a politikai közösség és annak vezetői hogyan tudják élvezni a specializációból fakadó előnyöket, s egyúttal minimalizálni a delegálásból fakadó hátrányokat (Feaver 1998, 408-409). A fenti problematikából alapvetően egy további részprobléma származtatható: a hadseregnek elég erősnek (kellöen felszereltnek, jól szervezettnek) kell lennie ahhoz, hogy védelmi feladatait elláthassa, ugyanakkor a felállításával és a fenntartásával kapcsolatos anyagi terhek nem jelenthetnek aránytalanul nagy terhet a politikai közösségre, a müködése pedig nem fenyegetheti a politikai közösséget. A hadsereg általi védelem (protection by the military) és a hadseregtöl való védelem (protection from the military) tehát szükségképpen valamiféle ellentétben áll egymással, mivel az egyikre irányuló törekvés általában némiképp a másikra irányuló törekvéseket gyengíti (Feaver, 1996, 152-154). Az előzőekben felvázolt problémakör abban az esetben is jelentkezik, ha egy államban a politikai hatalmat a hadsereg tagjai gyakorolják. Demokratikus társadalmakban, ahol a hatalomgyakorlás demokratikus felhatalmazás (választások) útján történik, a politikai vezetés és a hadsereg közötti kapcsolat kettős delegálási problémaként értelmezhető. Nem csupán a politikai vezetés delegálja az állam védelmi feladatait a fegyveres erőkhöz, a választópolgárok is felhatalmazzák a politikusokat a hatalom és benne az állami erőszak-monopólium gyakorlására (Feaver 1996, 153-154). Ebből pedig az következik, hogy noha a katonai vezetés általában szakmailag megalapozottabb döntést lenne képes hozni egy adott honvédelmi kérdésről, csak a politikai vezetés rendelkezik (az állampolgári felhatalmazás révén) elegendő legitimitással ahhoz, hogy a társadalmi prioritások és a társadalom által tolerálható terhek és költségek figyelembe vételével döntsön. Ez akkor is igaz, ha a civil vezetők döntése szakmailag helytelen, más szóval: a civileknek joguk van tévedni (Feaver 1996, 153-154). Hasonló gondolatmenetet követ Burk $(2002,2006)$ is, aki a civil-katonai kapcsolatok négy alapvető problémáját azonosította. Az első a „pretoriánus probléma”, azaz a hadsereg politikai beavatkozásának lehetősége. Ez tekinthető a legklasszikusabb és potenciálisan a legveszélyesebb problémának, azonban napjaink viszonyai között, legalábbis a demokratikus berendezkedésü államokban kevésbé releváns, ugyanis egy katonai államcsíny valószínüsége igencsak alacsony (Burk 2006, 118). 
A második probléma a „rend és fegyelem” fenntartásának problémája a fegyveres erők szervezetében: a megoldandó feladat tehát az, hogy „a fegyveres, fegyelmezett testület úgy viselkedjék, hogy védje az államot, anélkül, hogy - fegyelmezetlenség, szerencsétlenség, vagy a veszedelmek eltúlzása révén - ártana az államnak vagy polgárainak" (Burk 2006, 119). A harmadik, gyakran elhanyagolt probléma a hadsereg védelme a politikai vezetés túlkapásaitól, azaz az olyan politikusoktól, akik „netán pártérdekből, és a saját hatalmuk erősítésére használnák a fegyveres erő fölötti hatáskörüket” (Burk 2006, 119). Más szóval, itt a „civil kontroll kontrolljáról”, a haderőt ellenőrző kormány elszámoltathatóságáról és felelősségéről van szó. Végezetül a negyedik, az ún. „szakértői” vagy „információs” probléma, amit Huntington (1957) a „szakértő és a miniszter (politikus) viszonyaként” fogalmaz meg. Lényegében a probléma gyökere egy információs aszimmetria helyzet, mely a katonai vezetés és a politikusok között áll fent. Azaz: hogyan ellenőrizhetik hatékonyan a fegyveres erőket a civil politikusok, ha ehhez általában nem rendelkeznek kellő szaktudással, és a területtel kapcsolatos releváns információk forrása többnyire éppen az ellenőrzés tárgya, a katonai szféra? Mint Burk rámutat, a négy probléma egymással szorosan összefügg, a civil-katonai kapcsolatok egyik aspektusát sem lehet a többiek nélkül kezelni (Burk 2006, p. 118119).

Áttekintve a „civil-katonai ellentét” lényegét, és a civil-katonai kapcsolatok fogalmi meghatározására rátérve, e fogalom két értelmezése különíthető el. (Nelson 2002, 161). A fogalom „szükebb” értelmezése szerint, melyet a szakterület klasszikus szerzői, így Huntington (1957) és Janowitz (1960) is használnak, civil-katonai kapcsolatok alatt a katonai vezetés, illetve a politikai vezetés közötti kapcsolatokat értjük. A fogalomnak létezik azonban egy tágabb értelmezése is (lásd pl. Born et al 2006, 4-5, illetve Cottey, Edmunds és Forster 2002b, 6), ebben a civil-katonai kapcsolatok a hadsereg, mint társadalmi intézmény, és a tágabb társadalom közötti viszonyként határozható meg. Barany $(2012,25)$ a civil-katonai kapcsolatokat egy „háromszögnek” tekinti, melynek három „oldala” az állam, az államtól elkülöníthető "társadalom" és maga a hadsereg. Vankovska és Wiberg $(2003,1)$ a civil-katonai kapcsolatokat az állampolgárok, a hadsereg és a politikai elitek közötti kapcsolatok dinamikus rendszereként értelmezik.

Végezetül, szükségesnek tartom az általam a következőkben használni kívánt civilkatonai kapcsolatok fogalmától elhatárolni az egymáshoz némiképp hasonlatos civil- 
katonai együttmüködés (civil-military cooperation, CIMIC), civil-katonai koordináció (civil-military coordination, $\mathrm{CMCO}$ ), valamint civil-katonai műveletek (civil-military operations, CMO) fogalmakat.

Az Amerikai Egyesült Államok hadserege által használt civil-katonai műveletek (CMO) fogalma olyan katonai müveleteket jelent, ahol a katonai erők és a civil lakosság közötti interakcióra kerül sor a müvelet végrehajtásának megkönnyítése és a müveleti célok elérése érdekében (U.S. Department of the Army 2006, 1-1).

A NATO meghatározása szerint a civil-katonai együttmüködés (CIMIC), olyan, a művelet támogatását célzó együttmüködés és koordináció, mely a NATO illetékes parancsnoka és különböző civil szereplők, így a helyi lakosság és kormányzati szervek, illetve más nemzeti, nemzetközi vagy nem kormányzati ügynökségek és szervezetek között zajlik (NATO 2013, 2-1).

Az ENSZ békefenntartó müveletei során is alkalmazott civil-katonai koordináció (CMCO) a müvelet katonai komponense és a helyi civil lakosság, illetve humanitárius vagy nemzetközi fejlesztési szervezetek közötti információcsere, megállapodás vagy koordináció annak érdekében, hogy segítsék a müvelet végrehajtását (UN DPKO 2002, 2-3).

Mindhárom fogalom közös eleme, hogy egyfelől a két fél közötti kapcsolat vagy interakció egy katonai müvelet kontextusában fogalmazódik meg, másfelől pedig, ellentétben a civil-katonai kapcsolatokkal, ez esetben nem a fegyveres erők politikai vagy társadalmi kontrolljáról van szó, hanem a katonaság együttműködéséről nem katonai (civil) szereplőkkel a müvelet végrehajtása érdekében.

Jelen doktori értekezésben a korábbiakban elmondottakkal összhangban a civilkatonai kapcsolatok fogalmának „szükebb” értelmezésével fogok dolgozni.

James Burk fentebb említett gondolatai már részben érintették a civil és demokratikus kontroll kérdését is, mely ezen doktori értekezés másik kulcsfogalma. Egyfelől lényeges megállapítani, hogy a civil-katonai kapcsolat vizsgálható egy társadalmi és egy intézményes kontroll-problémaként is. A már említett Huntington és Janowitz - különböző módon és hangsúlyokkal - a társadalmi vagy „belső” kontroll kérdését helyezték vizsgálódásuk középpontjába. Egy politikatudományi nézőpontú elemzés számára azonban az intézményes vagy „külső” kontroll módjai és dinamikája a relevánsabbak. Jelen disszertáció - részben Feaver nyomán - szintén a kontroll, illetve a civil-katonai kapcsolat eme dimenziójára koncentrál (Feaver, 1996, 166-167). 
A kontroll tekintetében további különbséget kell tenni a fegyveres erők "civil" és "demokratikus" kontrollja között is. A haderő demokratikus kontrollja a demokratikus államokban a civil-katonai kapcsolatok egyik fő meghatározó eleme. Cottey és szerzőtársai $(2002 b, 6)$ a haderő demokratikus kontrollját úgy definiálják, mint a fegyveres erők politikai kontrollja a legitim, demokratikusan megválasztott közhatalmi szervek által. Érdemes ugyanakkor megjegyezni, hogy a modern demokráciákban a társadalom szerepe is fokozatosan növekszik a haderő demokratikus kontrolljában, a közvélemény, a média, a tudományos közösség és különböző nem kormányzati szervezetek révén (Barany 2012, 25-26). Noha a demokratikus kontroll szükségképpen civil kontroll, a civil kontroll nem minden formája tekinthető demokratikusnak. A kelet-közép-európai régió korábbi pártállami rendszereiben a haderő felett alapvetően civil ellenőrzés érvényesült, ez azonban az állampárt politikai ellenőrzése volt, melyet alátámasztott az állampárt intézményes jelenléte a fegyveres erőkben (pártalapszervezetek, politikai tisztek), a tisztikar jelentős részének vagy egészének párttagsága, a katonai elit egyes tagjainak a párt vezető grémiumaiban (például a Központi Bizottság), való jelenléte, valamint a katonák felé irányuló intenzív politikai-ideológiai indoktrináció is (Gow 1992, 2829). A haderő feletti kontroll jellege ez esetben a demokratikus átmenet során felmerülő kihívásokat is befolyásolta: a civil kontroll két formája közötti átmenetre került sor, a kommunista (egypárti) civil kontrollról a demokratikus civil kontrollra (Cottey et al 2002b, 3-4). Ez különbözött például a katonai rendszerek utáni demokratikus átmenetektől, ahol a haderö feletti civil ellenőrzés megteremtésére is szükség volt. Összefoglalva fentebb elmondottakat, a jelen alfejezetben bevezetett három fogalom egymáshoz való viszonyát az 1. ábra illusztrálja.

\section{1. ábra: A dolgozat három kulcsfogalma}

Civil-katonai kapcsolatok

\begin{tabular}{l}
\hline A haderő civil kontrollja \\
$\begin{array}{l}\text { A haderő demokratikus } \\
\text { kontrollja }\end{array}$ \\
\hline
\end{tabular}

Forrás: saját szerkesztés 


\subsection{Civil-katonai kapcsolatok az elmélet tükrében: bevezető gondolatok}

A civil-katonai kapcsolatok fontosabb elméleteinek tárgyalása előtt szükségesnek tartom néhány, ezen aldiszciplínát illető általános megállapítás megtételét.

Eltérően például a nemzetközi politika vagy az összehasonlító politikatudomány bizonyos területeitől, a civil-katonai kapcsolatok vizsgálata az elmúlt évtizedekben nélkülözte a nagy hatású elméleti vitákat. Ennek oka részben a területet érintő elméletalkotás hiánya, vagy korlátozott volta (Burk 2002, 7-8, Bruneau és Matei 2013). A diszciplína sokáig nem tudott túllépni annak klasszikusa, Samuel Huntington A katona és az állam (1957, 1994) címü müvében megalkotott paradigmán, noha ennek korlátait már a kortársak is felismerték (lásd alább, ill. Bruneau és Matei 2013). Problémát jelentett továbbá az elméletek alapvetően deskriptív jellege, a komparatív elemzésre való alkalmasságuk, valamint empirikus tesztelhetőségük korlátozottsága (Bland 1999, 233, Bruneau és Matei 2013). Az elméletek fogalomkészlete esetenként túl szükre szabott, a probléma fontos aspektusait mellözi (pl. csak a hadsereg politikai beavatkozására, azaz a katonai puccsok kérdéskörére koncentrál), vagy túlzottan ország- illetve kultúraspecifikus (Schiff 1995, Bland 1999, 8). További probléma a szakterülethez kapcsolódó tudományos tevékenység „ciklikus” jellege: az ötvenes-hatvanas évek „hőskorát” követően a civil-katonai kapcsolatok problémaköre újból csak a demokratikus átmenet „harmadik hulláma”, a posztszocialista átalakulási folyamat, valamint a hidegháború utáni időszak kapcsán került előtérbe (Bland, 1999, 8, Feaver, 1999, 212-213, Edmunds 2013, 48-49). Alapvetően az elméletalkotásnak ezen a területen két fő kérdésre kell választ találnia: az egyik a „miért”, a másik a „hogyan” kérdése. A „miért” kérdése azon magyarázó tényezőkre irányul, amelyek befolyásolják a civil-katonai kapcsolatok egyes mintáinak kialakulását, és szükebben véve, azt, hogy melyek azok a tényezők melyek a demokratikus civil-katonai kapcsolatok kialakítását és fenntartását elősegítik. Míg a „hogyan” kérdés arra vonatkozik, hogy milyen politikai vagy intézményes technikák segítségével biztosítható a haderő civil és demokratikus kontrollja. (ld. még Joó és Martinusz 1998, 10-15). A civil-katonai kapcsolatok klasszikus elméletei közül a két korai és legnagyobb hatású szerző, Samuel P. Huntington (1957, 1994) és Morris Janowitz (1960, 1971), valamint Samuel E. Finer $(1962,1976)$ munkáját tárgyalom. 
Az újabb keletü elméleti magyarázatok közül részben gyakorlati szempontok alapján, részben a disszertáció szempontjából történő alkalmazhatóságot szem előtt tartva választottam ki azokat, amelyeket jelen fejezetben vizsgálni fogok.

\subsection{A civil-katonai kapcsolatok klasszikus elméletei}

\subsubsection{Samuel P. Huntington: „professzionalizmus” és ,objektiv civil kontroll”}

Huntington „A katona és az állam” (1994) című művében a tisztikart állítja a vizsgálat középpontjába. Noha elemzése nem kifejezetten a civil kontroll, vagy a civil-katonai kapcsolatok témakörével foglalkozik, a müben erre vonatkozóan is számos elméleti megállapítás szerepel. A mü alapvetően történeti szemléletü és terjedelmének jelentős részében a professzionális tisztikar fejlődését, valamint a hadsereg és a társadalom közötti kapcsolatok alakulását vizsgálja az Egyesült Államokban ${ }^{4}$. Az elméleti felvetések, valamint az ebből levezetett szakpolitikai javaslatok a mü csak néhány fejezetét teszik ki.

Huntington fó elemzési kategóriái a hivatásos katonai etika (professional military ethics), valamint a professzionalizmus. A „professzionális” jelzőt a katonaságot illetően eltérően használja annak napjainkban használatos értelmezésétől: itt a professzionális hadsereget nem a sorozott hadsereg ellenpontjaként, hanem definícióját kifejezetten a hivatásos tisztikarra szűkítve egy olyan társadalmi csoportként definiálja, melyet sajátos szakmai és társadalmi értékek jellemeznek. Ennek a „különleges típusú elhivatottságnak” a fö jellemzői a szaktudás, a felelősségtudat és a testületi szellem (esprit de corps) (Huntington 1994, 13-14). A professzionalizmus kialakulását a szerző alapvetően történelmi kontextusban szemléli. A kialakulásának főbb tényezői szerinte a tisztikarba való bejutás és az előléptetés meritokratikus jellege (ellentétben pl. az arisztokrata származással vagy a rendfokozat megvásárolhatóságával), a szervezett katonai oktatás és képzés, a modern vezérkarok megjelenése, valamint a testületi szellem kialakítása. (Huntington i.m., 42-53). A „katonai etikát” egy olyan, térben és időben állandó világnézetként definiálja, mely a hivatás „folyamatos és objektív betöltése” nyomán alakul ki vagy erösödik meg a tisztikarban (Huntington i.m., 64-67).

\footnotetext{
${ }^{4}$ A könyv 17 fejezetéből 11 foglalkozik az USA-val
} 
A katonai etika azonban a professzionalizmus fogalmához is szorosan kapcsolódik. Mint a szerző megállapítja: „Bármely adott tisztikar csak olyan mértékben ragaszkodik ehhez az erkölcshöz, amennyiben az professzionális” (Huntington i.m., 66). A katonai etika főbb jellemzői Huntington szerint az antropológiai pesszimizmus, a nemzetközi kapcsolatok realista szemlélete, a nemzetállam elsőbbségébe, valamint az azt érő fenyegetettség állandóságába vetett hit. A katona, így Huntington, favorizálja a katonai erő növelését, azonban nem „militarista” a szó azon értelmében, hogy háborút kívánna: készül a háborúra, de nem akarja annak kirobbantását (Huntington i.m., 72-73). A civil és a katonai szféra viszonyára térve, a szerző megfogalmazása szerint a katona háromszorosan felelős az államnak. A képviseleti funkciójában a katona a katonai biztonság követelményeit képviseli az államgépezetben. A tanácsadói funkció lényege az állami vezetés tájékoztatása katonai kérdésekben, például egyes politikai opciók katonai megvalósíthatósága tárgyában. A katona azonban nem mondhat értékítéletet a felett, hogy melyik opció ,jó” vagy „rossz”.

Végezetül a végrehajtó funkció keretében a katona feladata a katonai biztonságra vonatkozó állami döntések megvalósítása, akkor is ha azokat katonai szempontból nem tartja racionálisnak (Huntington i.m., 75). Hogyan valósul meg, hogyan valósulhat meg a szerző értelmezésében a haderő civil kontrollja? Huntington szerint egyfajta zéró összegü játékról beszélhetünk a civil és a katonai szféra közötti kapcsolatokban, más szóval: „feltehetően a civil ellenörzés olyan mértékben valósul meg, amilyen mértékben csökkentik a katonai csoportok hatalmát" (Huntington i.m., 85). A civil ellenőrzésnek két formája lehetséges: a szubjektív civil kontroll, egy vagy több civil (nem katonai) csoport érdekeinek, szempontjainak figyelembe vételére irányul. Ez esetben tehát a hadsereget „civilesítik”, azaz a civilek képére formálják. Ezzel szemben az objektív civil kontroll tiszteletben tartja az autonóm katonai szférát: ekkor a hadsereget „militarizálják”, azaz katonai ügyekben elismerik különállását, sajátos belső viszonyait. A hadsereget ekkor politikailag gyengítik anélkül, hogy katonailag gyengítenék (Huntington i.m., 86-88). A korábban bevezetett professzionalizmus fogalma és az objektív civil kontroll koncepciója között is szoros kapcsolat van Huntington szerint. „Egy jól képzett hivatásos tisztikar készen áll bármely olyan nem katonai csoport kívánságainak teljesítésére, amely törvényes hatalomra tesz szert az államban" - jelenti ki a szerző (Hungtington i.m., 88). Azt azonban nem részletezi, hogy pusztán a tisztikar professzionalizmusa miért 
feltételezi törvényszerúen annak a törvényes hatalommal szembeni parancskövetö magatartását. A katonai professzionalizmus és az objektív civil kontroll mértéke a szerző szerint a társadalom egyes „strukturális” jellemzőitől, valamint az adott korszakban domináns politikai-társadalmi ideológiától függ. A strukturális tényezők között említhető a politikai és a katonai vezetés egységessége vagy széttagoltsága, és egymáshoz viszonyított hatásköre, valamint a katonai befolyás mértéke a katonai szférán kívül. Ez utóbbi négy indikátorral mérhető: a katonai elit rekrutációja és személyes kapcsolatrendszere, azon erőforrások mennyisége, amelyek felett ezen elit diszponálhat, a katonai vezetés hierarchikus pozíciója, valamint az általuk élvezett népszerüség és presztízs (Huntington i.m., 89-92).

Megvizsgálva négy, a XX. században jelentős szerepet játszott ideológiai irányzatot (liberalizmus, konzervativizmus, fasizmus, marxizmus) Huntington arra a következtetésre jut, hogy a konzervativizmus ${ }^{5}$ kivételével ezek nehezen egyeztethetők össze a hivatásos katonai etikával (Huntington i.m., 93-96). A szerző ismételten leszögezi, hogy míg a „civil gondolkodás” számos változata és irányzata létezik, ,a katonai etika konkrét, állandó és általános érvényü” (Huntington i.m., p. 92.). Az objektív civil kontroll megvalósulása a katonai hatalom és a társadalomban éppen domináns ideológia közötti megfelelő egyensúly létrejöttétől függ. A legtöbb társadalomban a ez az egyensúly dinamikusan változik, mely függ az egyes társadalmi csoportok közötti hatalmi viszonyoktól, a biztonsági fenyegetésektől, és a közvélemény vagy a domináns ideológia változásaitól (Huntington i.m., 96-97). Könyve megjelenésének időszakára, az ötvenes évek végi Egyesült Államokra vonatkoztatva a szerző azt a végkövetkeztetést fogalmazza meg, hogy ellentét feszül az amerikai liberalizmus és a katonai biztonság követelményei között. A folyamatos hidegháborús fenyegetettség körülményei között ahhoz, hogy a katonai professzionalizmust és az objektív civil kontrollt meg lehessen őrizni, Huntington szükségesnek látta a hadsereg számára „barátibb”, „konzervatív realista” ideológiai klíma felé való eltolódást (Huntington i.m., 445-446).

Mint az egyik legelső és később nagy hatásúnak bizonyult elméletet, Huntington felfogását az elmúlt évtizedekben számos szerző kritizálta. A huntingtoni elmélet nagy hatásához hozzájárult, hogy ,értő fülekre talált” az amerikai hivatásos katonatiszti kar körében, és az elmélet hosszabb ideje részét képezi az amerikai

${ }^{5}$ Lényeges ugyanakkor megjegyezni, hogy „konzervativizmus” alatt a szerző a Burke nevéhez köthető angolszász klasszikus konzervativizmust érti. 
katonai felsőoktatás tananyagának, valamint azon képzési programoknak is, melyeket az Egyesült Államok az átalakuló országok fegyveres ereje, illetve azok személyzete számára szervezett. (Bruneau 2013, 13-14, Feaver 2003, 7).

A legtöbb bírálat a civil és katonai szféra szigorú elkülönítésének huntingtoni tézisére, valamint a „professzionalizmus” koncepciójára irányult. A kritikák további forrása volt a „professzionalizmus” és a civil kontroll mértéke közötti, fordított arányossági kapcsolat feltételezése is (Burk 2002, p. 13, Feaver 1999, p. 235.). Mint Finer (1962, 1976) és később Stepan (1971), illetve Abrahamsson (1972) is rámutattak, attól, hogy egy hadsereg „professzionális”, még korántsem biztos, hogy tartózkodik a politikai beavatkozástól. Bruneau szerint pedig a „professzionalizmus” fogalma a „kultúra” fogalmához hasonlóan nehezen definiálható, valamint Feaverhez hasonlóan a szerző úgy érvel, hogy a huntingtoni gondolatmenet, ami a hadsereg politikai passzivitását (beavatkozásának hiányát) a „professzionalizmushoz” köti, tautologikus. A hadsereg, így Huntington, azért engedelmeskedik a civil hatalomnak, mert professzionális. Az azonban nem kerül meghatározásra, hogy hogyan és milyen módon vezet a „professzionalizmus” a stabil civil kontrollhoz (Bruneau 2013, 16, Feaver 2003, 18, Feaver 2006, 100).

Különösképpen az átalakuló országok kontextusában kell megemlíteni, hogy az érintett országok védelmi vitáiban a „professzionális”, „professzionalizáció” kifejezések két értelemben szerepeltek. A két fogalom első értelmezése hasonló a Huntington által kifejtetthez. A térségben a „professzionális hadsereg” kifejezés azonban gyakrabban az önkéntes haderőre való áttérésre vonatkozott, mely különösen a NATO-csatlakozási folyamatban részt vevő államok számára vált célkitűzéssé (Cottey et al 2005, 9). Marjan Malešič és szerzőtársai (Malesic et al 2015, 12) ennek nyomán megkülönbözetik a strukturális és a funkcionális professzionalizációt: strukturális vagy szervezeti professzionalizáció alatt a sorozottról a hivatásos hadseregre való átállást értik, míg a funkcionális professzionalizáció a fegyveres erők működésében a magasabb szakmai standardok bevezetését, elsajátítását jelenti. Ebben a tekintetben tehát Hungtington professzionalizmus-fogalma a funkcionális professzionalizmushoz áll közelebb.

Többen (Feaver 1996, Burk 2002) bírálták Huntington azon végkövetkeztetését, hogy az Egyesült Államoknak egy konzervatív realizmus felé kell fordulnia, ha a hidegháborús kihívásra sikeresen akar válaszolni. Ez a jóslat történelmi távlatban nézve nem, vagy csak részben igazolódott be: a szerző által kívánatosnak tartott, 
"konzervatív realistának" nevezett politikai környezet talán csak Ronald Reagan (1980-1988) elnökségét jellemezte, ennek ellenére a vietnami háború időszakát kivéve, a hidegháború alatt végig magas maradt a hadsereg társadalmi támogatottsága, és az ország „győztesen” került ki a hidegháborús szembenállásból. Mint Burk megjegyzi, a Szovjetunió paradox módon, noha egy autokratikus, militarizált társadalom volt és saját erőforrásai arányosan jóval nagyobb részét fordította a védelemre, részben ennek következményeként is a szovjet társadalmigazdasági berendezkedés megbukott, és az ország „elvesztette” a hidegháborút (Burk 2002, 13).

Mint korábban említettem, a huntingtoni modell elsődlegesen a társadalmi és nem pedig az intézményi kontroll-mechanizmusokra koncentrál: számára a stabil civilkatonai kapcsolatok eszköze a professzionalizmus. A szerző csak érintőlegesen foglalkozik az eredményesség (effectiveness) fogalmával, mint a civil-katonai kapcsolatok egyik lehetséges összetevőjével (Feaver 1996, 166-167, Feaver 1999, 211, Bruneau 2013, 17-18). A huntingtoni professzionalizmus-koncepciót több ponton bírálta Sam Sarkesian (1981) is. A professzionalizmus véleménye szerint nem értelmezhető térben és időben állandó, absztrakt kategóriaként, hanem csak azon társadalmi, politikai rendszer keretei között, ahol az adott hadsereg és az adott katonai vezetés müködik. Emellett a történelmi realitásoknak nem felel meg a civil és katonai szféra szigorú elkülönítése és a vegytisztán „apolitikus” tisztikar-kép sem. Ezzel szemben a szerző amellett érvel, hogy tényként kell elfogadni a katonai vezetés „politikai szereplő” mivoltát annyiban, hogy a demokratikus politizálás keretei között (leginkább informális csatornákon, pl. lobbi-tevékenység útján) törekszik egyes intézményi érdekeit érvényesíteni. Ez természetesen nem jelentheti a hadsereg pártpolitikai szerepvállalását. Ennek nyomán Sarkesian egy megújított professzionalizmus-koncepciót javasol, amelyet a „felvilágosult támogatás” (enlightened advocacy) névvel illet (Sarkesian 1981, 284-285, 291-294). Több szerző szerint (Burk 2002, Schiff 1995, Bland 2006) a huntingtoni elmélet túlzottan „etnocentrikus”, másképp fogalmazva Amerika-centrikus, azaz az Egyesült Államok történelmi, társadalmi hátterére és intézményes berendezkedésére szabott. Véleményem szerint további problémát jelent, hogy a huntingtoni modell nemcsak jelentős szerepet tulajdonít az ideológiáknak, de a „liberalizmus”, „konzervativizmus” és hasonló fogalmakat egyfelől „ideáltipikus”, másfelől pedig tartalmában állandó kategóriaként értelmezi. Ezen fogalmak jelentése és tartalma 
azonban térben és időben nagy változatosságot mutat, mely még inkább megnehezíti a huntingtoni modell komparatív elemzésekre való alkalmazhatóságát. Problémát jelent továbbá, hogy mint említésre került, Huntington szerint a „katonai etika” időben és térben állandó, noha mint például Bruneau is rámutatott, ez még amerikai viszonylatban sem jelenthető ki (Bruneau 2013, 16-17).

Herspring (1999) és Albright (1980) az elmélet kommunista rendszerekre, illetve a kommunista államok civil-katonai kapcsolataira való alkalmazhatóságát kérdőjelezte meg, különösen azt a feltételezést, hogy a kommunista hadseregekben szükségszerűen a „szubjektív kontroll” érvényesül. Huntington, a később bemutatandó Janowitzhoz hasonlóan, a biztonság katonai és államcentrikus felfogására építette elméletét. Ez a biztonságfogalom -és az állami szuverenitásátalakulása, a transznacionális fenyegetések előtérbe kerülése és nemzetközi katonai műveletek általánossá válása miatt egyre kevésbé tartható. A huntingtoni paradigma a hadsereg olyan, a tradicionális honvédelmi feladatkörtől eltérő szerepei tekintetében sem jelent iránymutatást, mint például a terrorizmus elleni harc, és a konfliktusok utáni újjáépítésben (post-conflict reconstruction) való részvétel, melyek a hidegháború utáni évtizedekben egyre inkább előtérbe kerültek (Burk 2002, 14, Nelson 2002).

Összegezve, alapvetően a már említett Thomas C. Bruneau értékelésével értek egyet: Huntington elmélete figyelemre méltó, mint normatív politikai elmélet, és mint bizonyos, a civil-katonai kapcsolatokhoz kötődő kulcsfogalmak korai konceptualizációs kísérlete, azonban csak korlátozottan tekinthető komparatív elemzésre alkalmas elméleti modellnek (Bruneau 2013, 19).

\subsubsection{Morris Janowitz és a ,, szociológiai” megközelités}

Az ún. katonaszociológiai iskola egyik megalapítójának számító Morris Janowitz Huntingtonhoz hasonlóan a hivatásos katonát állította vizsgálódása középpontjába, azonban némileg eltérő szemléletmóddal. A szerző itt ismertetésre kerülő műve alapvetően szociológiai jellegü (ezt tükrözi a könyv címe is: The professional soldier - A social and political portrait), azonban egyes következtetései a civil-katonai kapcsolatok, valamint a haderő civil kontrollja szempontjából is relevánsak (Janowitz 1960, 1971). Janowitz müvének alaptézise, hogy az atomfegyverekre épülő elrettentés, a hidegháború nemzetközi rendje és a haditechnika rohamos 
fejlődése körülményei között az I. és II. világháborúhoz hasonló „totális háború” fogalma érvényét vesztette. Ez pedig nem csak a katonai hivatást fogja fokozatosan átalakítani, hanem lényeges következményekkel bír a katonaság és a politika viszonya, más szóval a civil-katonai kapcsolatok számára is (Burk 2002, 11).

A hadsereg jellemző trendje a fokozódó „menedzserizálódás”, a klasszikus „hősi” katonai vezető szerep mellett mind inkább megerősödik a menedzser és a technikai specialista szerepe. Mindezen folyamatok, a katonatiszti állomány társadalmi összetételének heterogénebbé és társadalmilag reprezentatívabbá válása mellett oda vezetnek, hogy részben elmosódnak a katonai és a civil szféra közötti határvonalak, a hadsereg „civilesedése” (civilianisation) megy végbe (Janowitz 1971, 264-267).

Az erő alkalmazását illetően a szerző szerint ellentét feszül az „abszolutista” és a „pragmatikus” felfogású tisztek álláspontja között. Előbbiek közelebb állnak a totális háború - Janowitz szerint immár idejétmúlt - logikájához, és a „győzelem” hagyományos felfogásához, míg utóbbiak hajlamosak elfogadni a limitált erőszakalkalmazás szükségességét a megváltozott körülmények között (Janowitz 1971, 264267).

A janowitzi „,ideális” hadseregkép elsősorban a demokrácia klasszikus republikánus (civic republican) demokráciafelfogásából táplálkozik, mely szerint a demokrácia életképességének egyik feltétele a közéletben való állampolgári részvétel, melybe az állam védelmében való közremüködés is beletartozik. Janowitz tehát a „katonaállampolgár" (citizen soldier) koncepcióját javasolja annak biztosítására, hogy a civil-katonai kapcsolatokban érvényre jussanak a demokratikus értékek (Burk 2002, 10-12). Ugyanakkor a szerző azt is felismerte, hogy ez csak a „totális háború” körülményei között, az olyan rendkívüli esetekben lehetséges, mint a második világháború. A tömeges mobilizáció hiányában az állampolgári erények elterjesztését egy katonai komponenst is tartalmazó közösségi szolgálati rendszer révén látta biztosíthatónak. A valóságban azonban politikai és társadalmi támogatottság híján ezen elképzelés megvalósításának nem volt realitása (Burk 2002, 13-14.).

Érdemes megjegyezni, hogy noha a könyv még az amerikai általános hadkötelezettség eltörlését (1973) megelőzően íródott, a sorkatonasággal kapcsolatos társadalmi attitüdök tekintetben viszont az Egyesült Államok esete nem tér el a sorozást később megszüntető európai országok tapasztalataitól. Igen figyelemreméltóak a szerző által a haderő jövőbeli önképéről írottak, amely szerint a hadseregnek a jövőben egyfajta „rendvédelmi” vagy „csendőri” koncepciót 
(constabulary concept) kell magáévá tennie: ,a haderő szervezete rendvédelmi erővé válik, ha folyamatosan harckészültségben tartják, minimális erőbevetés mellett kötelezi el magát, és győzelem helyett kedvező nemzetközi kapcsolatokra törekszik". Noha mint Janowitz hangsúlyozza, a „rendfenntartás” csak nemzetközi kontextusban értendő (Janowitz 1971, 418, Feaver 2006, 101). Milyen következtetések vonhatóak le a janowitzi elméletből a haderő civil kontrolljával kapcsolatban? Mint Feaver kifejti, noha a szerző meglátása a haderő jövőjével kapcsolatban ,jóslatértékünek bizonyult, ám arra nézve nemigen kínál alternatívát, hogy a civil szféra miként biztosítsa az ellenőrzést intézményi szinten, vagyis miként oldja meg az állam a civil kontrollt”. Janowitz a civil kontroll lehetséges eszközeinek igen rövid, majdhogynem címszavas felsorolására szorítkozik müvében, mely némileg ellentétben áll a katonatiszti hivatás azon aprólékos szociológiai elemzésével, melyre a The professional soldier vállalkozott (Feaver 2006, pp. 101-103). Mint Feaver rámutat, a civil kontroll egyik sarokköve Janowitz számára a „hivatásosok etikája” (professional ethics), mely alapjában véve kevéssé tér el Huntington professzionalizmus-fogalmától. A haderő feletti civil kontroll intézményi aspektusa Janowitz munkájából is jó részt hiányzik, a civil kontroll kérdéséhez inkább a társadalmi kontroll irányából közelít: a hadsereg és a társadalom szorosabb integrációja itt a társadalmi kontroll egyik eszköze. (Feaver 2006, pp. 103-104) Janowitz helyesen ismerte fel, hogy a civil és a katonai szféra egymástól nem elválasztott, modellje annyiban közelebb áll a valósághoz, hogy kitér a katonai vezetés, mint sajátos ágazati lobbicsoport tevékenységére, és az Egyesült Államok példáján bemutatja, a katonatiszti réteg hogyan próbálja érdekeit a demokratikus politikai döntéshozatal intézményrendszerében érvényre juttatni. (Janowitz 1971, 363-369, Burk 2002, 14-16, Feaver 2006, 101-102). Noha a hidegháborús szembenállás kellős közepén, 1960-ban megjelent munka jóslatai annyiban profetikusnak bizonyultak, hogy a haderők már a hidegháború időszakában, de különösen az azt követő időszakban a limitált háború és a „rendvédelmi” vagy „csendőri” koncepció felé mozdultak el, a nemzetközi környezetre vonatkozó egyéb megállapításai kevésbé állták ki az idő próbáját. Mint Burk megjegyzi, Janowitz, Huntingtonhoz hasonlóan a totális állami szuverenitás és az államközpontú nemzetközi kapcsolatok koncepciójából indult ki, és a civil-katonai kapcsolatok világára is mindketten ezt alkalmazták. Napjainkban, az átértékelődő állami szuverenitás, valamint a nemzetközi katonai műveletek körülményei között ez a 
nemzetközi kapcsolatokra vonatkozó hungtingtoni-janowitzi elöfeltevés jóval kevésbé tartható (Burk 2002, 14, 21-23). Végezetül mind Huntington mind pedig Janowitz (előbbi explicit, utóbbi implicit módon) a professzionalizmus, valamint a hadsereg civil kontroll alá rendelhetősége között oksági kapcsolatot feltételez, mely feltevést a korábbi és a kortárs szakirodalom egyaránt részletekbe menően bírált (lásd pl. Feaver 1999, 235-236).

\subsubsection{Samuel E. Finer: A hadsereg politikai beavatkozásának problémája}

A civil-katonai kapcsolatok klasszikus elméletei között harmadikként a brit Samuel E. Finer munkáját elemzem. Finer az először 1962-ben megjelent The Man On Horseback címü könyvében a hadsereg politikai beavatkozásának problémáját vizsgálja. A szerző alaptézise abban összegezhető, hogy nincs okunk feltételezni, hogy a hadsereg civil kontrollja valahogyan "természetes". Ahelyett, hogy azt kérdezzük, miért avatkozik be a hadsereg a politikába, lehetséges, hogy azt a kérdést kellene feltennünk, hogy miért nem teszi (Finer 1975, 6). Mint ahogy Finer találóan megjegyzi: "Első ránézésre nyomasztónak tünik a hadsereg politikai fölénye a civil (politikai) intézményekkel szemben. A hadsereg riválisainál sokkal jobb szervezeti háttérrel bír. Mindemellett, fegyverekkel is rendelkezik." (Finer i.m., 4)

A modern hadseregek erős belső kohézióval bíró, hierarchikus intézmények, kifejlett csoportöntudat és testületi szellem jellemzi tagjaikat, valamint a katonai hivatáshoz közkeletủen társított ún. "katonai erények" (úgymint bátorság, hazafiasság, hősiesség) számos korban és számos társadalomban jelentős elfogadottságnak örvendenek. Ezen tulajdonságok elviekben a hadsereget, mint potenciális politikai szereplőt segítenék. (Finer i.m., 5-9)

A fegyveres erők azonban két politikai gyengeséggel is rendelkeznek: egyfelől a gyakorlati képtelenség arra, hogy egyedül irányítsanak egy komplex társadalmat, valamint a legitimitás, azaz a hatalom gyakorlására való társadalmi és morális felhatalmazás hiánya (Finer i.m., 10-14). A hadseregek ugyanakkor a valóságban korántsem monolitikus intézmények, választóvonalak vannak az egyes fegyvernemek, vagy a tisztikar, illetve annak egyes generációi és a legénységi állomány között. Előfordulhat, hogy egyéb, a társadalomban meglévő törésvonalak így vallási vagy felekezeti, ideológiai, társadalmi osztály alapú ellentétek - is "átvivődnek" a fegyveres erőkre. Első ránézésre paradox módon, minél 
megosztottabb a fenti szempontok mentén egy hadsereg, annál nagyobb az államcsíny valószínüsége. Ugyanakkor egy sikeres puccsot elkövető katonai csoport annál nehezebben tudja a hatalmát megtartani, minél megosztottabb a hadsereg és maga a társadalom (Finer i.m., 225-228). A katonai beavatkozás szempontjából a szélesebb társadalmi és politikai környezet körülményei is szerepet játszanak. Ezek közül a politikai intézmények és hatalomgyakorlási formák erősségére és legitimitására Finer a „politikai kultúra” kifejezést vezette be. Ebben a tekintetben a kifejezés értelmezése eltér a mainstream politikatudományban használatostól (lásd Almond és Verba 1963). Egy olyan országban, ahol a politikai intézmények széles körben elfogadottak, a hatalomváltás módszerei kidolgozottak és mindenki tiszteletben tartja azokat, valamint a civil társadalom és a politikai közvélemény erős, a katonaságnak igen kis tere van a politikai intervencióra (Finer i.m., 18-19).

A hadsereg politikai beavatkozásának valószínűsége tehát függ egyfelől a társadalmi, politikai körülményektől, ahol az adott hadsereg müködik ("politikai kultúra"), másfelől a fegyveres erők hajlandóságától. A hajlandóság egyik összetevője racionális jellegü, ez az indíték, a másik pszichológiai jellegü, a "hangulat" (mood) (Finer i.m., p. 20).

Az indítékok részletes vizsgálata előtt a szerző azt a kérdést teszi fel, hogy a hadsereg professzionalizmusa valóban védelmet jelent e politikai beavatkozásuk ellen, mint azt korábban Huntington állította. A történelem számos esetet ismer amikor "professzionálisnak" tekintett hadseregek jelentős politikai szerepet játszottak (a császári és a weimari Németország, a két világháború közötti Japán), valamint létezhetnek olyan helyzetek amikor konkrétan a professzionalizmus egy bizonyos felfogása vezethet a politikai beavatkozáshoz (Finer i.m., 21-22). Előfordulhat, hogy fegyveres erők professzionalizmusának és politikafüggetlenségének eszméje olyan formát ölt, amikor a katonák úgy gondolják, ők "az államot" szolgálják és nem az éppen hatalmon lévő kormányzatot. Egy másik esetben a fegyveres erők egyfajta végső szaktekintélynek tekinthetik magukat a hadsereg ügyeit illetően, melyet megkísérelhetnek a politikában is érvényesíteni. Finer tehát arra a következtetésre jut, hogy a professzionalizálódás önmagában nem tud gátat vetni a hadsereg politikai beavatkozásának, ehhez szükség van arra is, hogy elfogadják a fegyveres erők feletti civil felsőbbség (civilian supremacy over the military) eszméjét. Ez utóbbit a szerző akként definiálja, hogy mind formálisan mind ténylegesen a kormány főbb intézkedéseiről és programjairól az ország politikailag felelős civil vezetőinek kell 
dönteniük (Finer i.m., 20-24).

A tulajdonképpeni indítékok a szerző nyomán két fő csoportba oszthatók: a nemzeti érdek a hadsereg általi sajátos interpretációja és a különböző csoport- vagy részérdekek nyílt vagy burkolt képviselete. Az első esetben a katonaság önmagát a nemzeti érdek, illetve a nemzeti függetlenség és szuverenitás egyedüli igazi letéteményesének tekinti, vagy úgy gondolja, hogy az ő küldetésük az általuk kívánatosnak tartott értékek vagy eszmék érvényre juttatása a társadalomban. Az, hogy mit tekintenek katonák "nemzeti érdeknek", országtól és történelmi kortól függően változhat, a nemzeti érdekről alkotott katonai koncepció viszont szinte mindig kapcsolódik valamennyire a hadsereg testületi- vagy csoportérdekeihez (Finer i.m., 30-34).

Sokszor azonban a nemzeti érdekre hivatkozás csak egy álca, ami a politikába beavatkozó katonaság által képviselt részérdekeket próbálja elfedni. Ezek alapvetően négy nagyobb csoportba sorolhatók. Az első a társadalmi osztály- vagy csoportérdek, mely a katonai beavatkozást önmagában ritkán magyarázza. Jelentősebb magyarázó erővel bír a második, a regionális, etnikai vagy vallási-felekezeti hovatartozás. (Finer i.m., 35-38, 228-230) A harmadik és negyedik ide tartozó indíték, a testületi érdek és az egyéni érdek egymástól nem mindig választható el élesen. Noha testületi érdekeit valamilyen formában a világ majd minden hadserege igyekszik képviselni, előfordulhat, hogy a katonaság úgy tekinti, bármely a hadsereget érintő kérdésben csak ök jogosultak döntést hozni, vagy más szakpolitikai területeken, így a gazdaság és a külpolitika terén is a hadseregnek kedvező döntéseket kívánnak érvényre juttatni (Finer i.m., 41-48, 49-51). Lényeges azonban megemlíteni, hogy a beavatkozás ritkán vezethető vissza egyetlen indítékra, általában indítékok egy bizonyos kombinációjáról beszélhetünk (Finer i.m., 52). Az indíték mellett a hajlandóság másik összetevője pszichológiai jellegü, amit Finer "hangulatnak" nevez. Ennek a szerző szerint mindig részét képezi egy erős csoportöntudat, mely a katonaság civilektől elkülönült identitásából táplálkozik. Ez a konkrét mozgatórugó lehet valamilyen sérelem (például egy megalázó katonai vereség) a civilekre történő indulat-kivetítés (projekció), vagy pedig a hadsereg kollektív felsőbbrendűségi tudata (Finer i.m. 54-55, 63).

A racionális és emocionális tényezők által befolyásolt hajlandóság mellett azonban szükség van olyan helyzetekre amikor a hadsereg katonai beavatkozására a siker reményében kerülhet sor, ezt Finer a lehetőségként azonosítja. A katonai beavatkozás 
számára legjobb esélyekkel kecsegtető helyzetek olyanok, amikor a civil hatalom belső vagy külső körülmények miatt a hadseregre utalt, valamint egyszerre tapasztalható a hadsereg relatív népszerüsége és a civil kormányzat relatív népszerütlensége vagy diszkreditálódása (Finer i.m., 64-71).

Az indítékok és a lehetőségek figyelembe vételével négy eset lehetséges:

1./ van hajlandóság és van lehetőség: nagy eséllyel sor kerül beavatkozásra

2./ nincs hajlandóság és nincs lehetőség: nem kerül sor beavatkozásra

3./ van hajlandóság és nincs lehetőség: sikertelen puccskísérlet vagy katonai lázadás

4./ nincs hajlandóság de van lehetőség: nagy eséllyel ekkor sem kerül sor beavatkozásra

Az utolsó esetben a beavatkozás nem feltétlenül azért marad el, mert a hadsereg teljes mértékben elfogadja a civilek politikai felsőbbségét: az is lehetséges, hogy a katonák úgy gondolják, "még nem jött el az ideje" a politikai beavatkozásnak (Finer i.m., 74-75).

A külső fenyegetések, háborúk gyakran megjósolhatatlanok, érvel a szerző, viszont a fentebb említett belső válsághelyzetek előfordulása is függ attól, hogy mennyire erősek és elfogadottak a civil (nem katonai) hatalomgyakorlás intézményei, mennyire kiépültek az intézményes érdekcsoportok (társadalmi szervezetek, egyházak, szakszervezetek, ipari kamarák, civil szervezetek, pártok), és mennyire müködőképesek az érdekegyeztetés és a konfliktusok megoldásának békés módjai (Finer i.m., 78-79).

Más szóval, minél nagyobb a társadalom kötődése a civil hatalomgyakorláshoz, annál kisebb az esélye, hogy a katonák meg fognak próbálkozni a hatalom átvételével, illetve, hogy ez a kísérlet sikeres lesz. Ezt Finer a "politikai kultúra szintjének" nevezi (Finer i.m., 75-76). A szerző szerint tehát az országok besorolhatók a "politikai kultúra" jelen értelmezése szerinti kategóriákba, ami részben meghatározza a fegyveres erők politikai mozgásterét (Finer i.m., 18-19). A szerző gondolatmenete szerint nem csak az függ a politikai kultúra szintjétől, hogy sor kerül e katonai beavatkozásra, hanem az is, hogy ez milyen formában történik (Finer i.m., 75-76, 78-79). Mindezen szempontok figyelembe vétele alapján Finer érett, fejlett, alacsony és minimális szintű politikai kultúrával rendelkező országokat különít el. (Finer i.m., 78-79) Az államok elhelyezkedése a politikai kultúra skáláján nem állandó, esetenként rövid idő alatt is változhat. A változás oka lehet a politikai részvétel kereteinek tágulása, vagy a modern értelemben vett politikai közvélemény 
növekedése, vagy ennek nagyobb mobilizálhatósága, amely például az írástudás szintjétől, az iparosodástól, vagy az urbanizáció mértékétől is függ (Finer i.m., 124). A katonai államcsíny csak egy lehetséges módja a hadsereg politikai beavatkozásának, melynek a szerző négy fő típusát azonosítja. Az első a befolyás alkalmazása: ekkor a katonaság képviselői érzelmi vagy racionális érvekkel próbálnak hatni a politikusokra a saját céljaik elérése érdekében. Ez a forma majd minden országban létezik, legitim és a civil kontroll eszméjével teljes mértékben konzisztensnek tekinthető. A második szint a nyomásgyakorlás vagy súlyosabb esetben zsarolás: ekkor a hadsereg már valamilyen szankciót is kilátásba helyez, ha az igényeit nem teljesítik. A beavatkozás ezen formája már a legtöbb esetben ellentétes a civil kontroll koncepciójával, ugyanakkor ennek megítélése nem mindig egyértelmü. Ebben a két formában a hadsereg közvetlen politikai szerepvállalásával még nem találkozunk, ellentétben a beavatkozás harmadik és negyedik szintjével, amelyeket Finer a civil kormányzat elmozdításának (displacement) vagy felváltásának (supplantment) nevezi. Az elmozdítás esetében a katonák a hatalmon lévő kormányzatot erővel vagy azzal való fenyegetés útján eltávolítják és egy másikat ültetnek a helyére. Ekkor a civil kormányzás megmarad. A negyedik, a felváltás a klasszikus katonai hatalomátvétel esete amikor a hadsereg megdönti a fennálló kormányt és magához ragadja a hatalmat, a civil kormányzást megszüntetik (Finer i.m., 76-77, 137-139). Fontos eleme egy puccs sikerének, hogy szervezői minél gyorsabban és minél kisebb véráldozat árán tudják a céljukat elérni. Ehhez az kell, hogy a politikusok és más társadalmi erők ne tanúsítsanak ellenállást és a hadsereg nem puccsista része se forduljon a lázadók ellen. Ha ez nem teljesül, a civilek és a hadsereg "lojális" része le tudja verni az államcsíny-kísérletet. Legrosszabb esetben a puccsisták nem tudják a hatalmat megragadni, a lojális erők viszont ahhoz elég erősek, hogy ellenálljanak, de ahhoz túl gyengék, hogy legyőzzék a puccsistákat. Ilyenkor polgárháborúba torkollik az államcsíny-kísérlet: ez történt 1936-ban Spanyolországban (Finer i.m., 146-147).

Vizsgáljuk meg ezt követően a katonaság politikai beavatkozásának egyik lehetséges eredményét, a katonai rendszereket. Finer definíciója szerint a katonai rendszer olyan politikai berendezkedés, ahol a hatalmat a hadsereg gyakorolja, vagy annak gyakorlása döntően az ő utasításukra és akaratuk szerint történik (Finer i.m., 149). Finer alapján direkt (közvetlen), indirekt (közvetett) vagy duális (kettős) jellegü katonai rezsimeket lehet megkülönböztetni. Közvetlen katonai hatalomgyakorlás 
esetén a kormány tagjai vagy a fegyveres erők soraiból kerülnek ki, vagy egy teljességgel a katonaság által irányított civil "bábkormányról" beszélünk. Ha a hatalomgyakorlás indirekt, a kormány alapvetően civilekből áll és civil jellegü, de a politikaformálás vagy döntéshozatal valamely, vagy minden területére (akár időszakosan akár folyamatosan) a hadseregnek döntő befolyása van. Duális jellegü rendszer esetén a -többnyire a katonák közül kikerülő- vezető uralmának fenntartása érdekében egyszerre támaszkodik a hadseregre és egy attól független, de meghatározó nem katonai társadalmi csoportra (Finer i.m., 149-151, 157-158). A katonai rendszer formája hasonlóképpen a „politikai kultúra” szintjéhez az idő során külső és belső tényezők hatására rövid idő alatt is változhat: indirekt hatalomgyakorlás helyett a hadsereg közvetlenül magához ragadhatja a hatalmat, vagy egy nyílt katonai diktatúra teret engedhet a -névleges- civil kormányzásnak (Finer i.m., 167-168).

Finer szerint a civil hatalomgyakorlás stabilitásában szerepet játszik az is, hogy az adott állam mekkora múltra tekinthet vissza és milyen módon jött létre. Ha véres polgárháború vagy gerillaháború vezetett az állam létrejöttéhez, ez kevéssé segíti elő a civil kontroll hagyományainak a megszilárdulását. Ily módon egy újonnan létrejött állam, ahol a politikai legitimitás vitatott, a hadseregen kívüli szervezett társadalmi csoportok gyengék vagy hiányoznak, és a nemzeti függetlenség kivívására fegyveres konfliktus következtében került sor, különösen sérülékeny lesz a hadsereg politikai beavatkozásával szemben. Finer szerint ez az egyik magyarázata annak, hogy a katonai puccsok különösen gyakoriak a második világháború után létrejött ún. fejlődő országokban (Finer i.m., 204-210).

Finer munkájának fö érdeme annak kimutatása, hogy nem magától értetődő a hadsereg civileknek való alárendelődése, ennek tartós fennmaradásához számos tényezőre van szükség. Ugyanakkor az elmélet egyik jelentős fogyatékossága, hogy túlzott mértékben a civil-katonai kapcsolatok válságának legsúlyosabb és leglátványosabb esetére, a katonai hatalomátvételre koncentrál. Noha a „politikai kultúra szintjeinek” bevezetésével a szerző kísérletet tesz annak magyarázatára is, hogy a stabil demokráciákban miért nem, vagy csak igen ritkán kerül sor a hadsereg politikai beavatkozására, a fineri elmélet alapvetően az ún. fejlődő országokra koncentrál, melyben a katonai hatalomátvételek a leggyakoribbak (voltak). Ebből következően az elmélet korlátozottan alkalmas a posztkommunista átmenet körülményeinek vizsgálatára. 


\subsection{A civil-katonai kapcsolatok kortárs elméletei}

A civil-katonai kapcsolatok kortárs elméletei több konkrét kérdésre vagy problémára keresték a választ. Az egyik azon jelenség, melyet Szabó János (1998, 18) a klasszikus elméletek hidegháború utáni időszakban történő „elfáradásának” nevezett: azaz a jelentősen megváltozott történelmi, társadalmi környezetben, és a hadseregek felépítésének, valamint küldetésének átalakulása miatt a korábbi elméletek csak korlátozottan alkalmasak a civil-katonai kapcsolatok dinamikáinak vizsgálatára. A hadseregek változó feladatai és küldetései összefüggenek az alkalmazott biztonságfogalom kitágulásával, az új típusú fenyegetések előtérbe kerülésével is. Az új elméletek egy része a klasszikus elméletek Amerika-centrikusságát, vagy a civilkatonai konfliktus legsúlyosabb problémáira (katonai puccsok) korlátozottságát kívánta meghaladni, illetve a komparatív elemzésre való alkalmazhatóságot tartotta szem elött.

A Douglas L. Bland által kidolgozott megosztott felelösség elmélete fö gondolata, hogy a hadsereg feletti vezetés és irányítás felelőssége a civil és katonai szereplők között megoszlik. A felelősség megosztásának módja és formája a szerző szerint egy rezsimként értelmezhető -itt Bland a nemzetközi kapcsolatokból is ismert rezsimelméletet (Krasner 1983) hívja segítségül-, melynek „paraméterei” az idő folyamán és a külső és belső körülmények alakulásával dinamikusan változnak (Bland 1999, 9-10). A megosztott felelősség elmélete két előfeltevésre épül: az első szerint a civil-katonai problematika felmerüléséhez egymástól elkülönült civil és katonai szférákra van szükség. A második feltevés szerint a civil kontroll dinamikus folyamat, amelynek formája és jellege a külső és belső körülmények -személyiségek, ideológiák, fenyegetés-percepciók, háborúk és válságok- alakulásával folyamatosan változik (Bland 1999, 10). Az elmélet a realitásokhoz kíván alkalmazkodni, hogy midőn a kontroll szerepköre egyértelműen a politikai vezetés kezében van, a valóságban a (civil) politikusok nem nélkülözhetik a katonai vezetés szakértelmét, valamint a katonai elit az általuk vezetett szervezet jellegéből eredően jelentős „negatív hatalommal” bír, azaz hatékonyan képesek bizonyos őket érintő szakpolitikai döntések végrehajtását késleltetni vagy szabotálni (Bland 1999, 10-11). Felmerül a kérdés, hogy miként érvényesül a megosztott felelősség a fegyveres erők civil ellenőrzésében, azaz hogyan osztozik eme felelősségben a katonaság a politikai vezetőkkel. Bland szerint a gyakorlat azt mutatja, hogy a tisztikar történelmi 
korszakokon és politikai rendszereken átívelő módon mindig is szerepet játszott a fegyveres erők ellenőrzésében, s nincs ez másként azon politikai rendszerek esetében sem, amelyek a haderő demokratikus kontrolljára épülnek. Ennek bizonyos esetei viszonylag egyértelmüek, ide tartozik például a katonai vezetők azon feladata, hogy megfelelő rendet és fegyelmet tartsanak a hadseregen belül. Ha a hadsereg vezetői értékként kezelik a civil kontrollt, a hadseregen belül fel fognak lépni ennek védelmében, például fellépnek az olyan tisztek ellen, akik a civil hatalom megdöntésére készülnek (Bland 2006, 120-121).

Van azonban az éremnek egy másik oldala is: a demokratikus rendszerekben a hadsereget a pártok és egyes politikusok politikai beavatkozásától is védeni kell. Ennek egyik eszköze a parancsnoki lánc, mely megakadályozza, hogy a politikusok közvetlenül parancsokat adhassanak egyes tiszteknek vagy egységeknek. Végezetül, a katonai vezetők a már említett „,információs probléma” kontrollálásában is szerepet játszanak: a civil politikusok rászorulnak a tisztek szakmai tanácsaira, ugyanakkor a tisztek hosszú távú, intézményes érdekei is azt kívánják, hogy megbízható partnerek legyenek a politikai vezetés szemében (Bland 1999, 13-15). Bland következtetése szerint tehát a megosztott felelősség minden civil-katonai kapcsolatban jelen van, de ennek mértéke, valamint az „osztozás” jellege időben és térben nagy változatosságot mutathat, és egy adott államban is változhat az idő múlásával. A rezsimelmélet bevezetése a civil-katonai kapcsolatok vizsgálatába olyan hasznos elemzési keretet alkothat, mely lehetővé teszi e változások követését, valamint a változásokat magyarázó tényezők vizsgálatát (Bland 1999, 16-17, Bland 2006, 120-121). Ebben a megközelítésben két esetben alakulhatnak ki „stabil” civil-katonai kapcsolatok: az egyik a civil politikusok által létrehozott és a katonák által is elfogadott, tiszteletben tartott erős rezsimek, melyek biztosítják az autonómia egy adott mértékét és ennek kölcsönösen tolerálható korlátait. A másik eset a katonák által létrehozott erös rezsim esete, azaz a katonai uralom lenne, amely természetesen nem jelent civil kontrollt (Bland 1999, 17).

A rezsimelmélet és a kölcsönös felelősségi elmélet kombinációja a szerző szerint a civil-katonai kapcsolatok dinamikáinak megértésére is lehetőséget kínál. Ideális esetben egy, mind a két szereplö (civilek és katonák) által kölcsönösen elfogadott és tiszteletben tartott szabályrendszer keretei között „lejátszódó” interakciók sorozatáról beszélhetünk.

Demokratikus rendszerekben Bland szerint a két fél között az eljárási és 
döntéshozatali, tehát technikai kérdésekben alakulhat ki nézetkülönbség, míg az alapelveket és normákat egyik fél sem kérdőjelezi meg (Bland 1999, 17-18). A civilkatonai interakciók rendszerének leírásában Bland támaszkodik a már említett Sam C. Sarkesian (1981) elméleti munkáira. A civil és katonai vezetés közötti kapcsolat Sarkesian szerint szimbiotikus és aszimmetrikus jellegü. Szimbiotikus, mert sokszor a „kölcsönös egymásra utaltság” fogalmával jellemezhető és aszimmetrikus, mert a katonaságra jelentős szerep hárul a demokratikus állam védelmében, viszont a civil vezetéssel fenntartott kapcsolatokat meghatározó ,játékszabályokat” a civil vezetés alakítja ki (Sarkesian 1981, pp. 291-293). Bland felteszi azt a kérdést, hogyan vagy milyen mértékig beszélhetünk „civil kontrollról”, amikor ennek müködése vagy megvalósulása esetenként csak a hadsereg együttmüködésével lehetséges? A szerző válasza szerint a megoldás kulcsa a „civil kontroll” új konceptualizálása, mely a katonaság társadalmilag elfogadott célok felé irányításában jelölhető meg (Bland 1999, pp. 18-19). A megfelelő és hatékony civil kontrollt biztosító rezsim kiépítése mellett azonban az elszámoltathatóság megfelelö mechanizmusaira is szükség van annak érdekében, hogy ténylegesen arról lehessen beszélni. Ily módon tehát a civil kontroll immár nem csupán a puccsok hiányát, vagy azok megtörténtét kizáró intézményi és normatív feltételek meglétét jelenti, hanem a közös felelősség gyakorlásának kereteit lefektető, hatékonyan müködtethető és érvényesíthető rezsimet is. Míg a katonai vezetés elszámoltathatósága a politikai elit feladata, a politikusok elszámoltatását demokratikus társadalmakban a választók, a média és a civil társadalom biztosítja (Bland 1999, 20). Bland - a rezsimelmélet egyik úttöröje, Stephen Krasner definícióját alapul véve - a civil-katonai kapcsolatokat szabályozó rezsimeket olyan alapelvek, normák szabályok és döntéshozatali eljárások összességeként definiálja, melyek a szereplők magatartását és várakozásait alakítják. (Krasner 1983, 1, Bland 2001, 526). Mint a szerző találóan megfogalmazza, míg az intézményrendszer és a döntéshozatali formák a civil kontroll „hardvere”, az alapelvek, normák és szabályok azon „szoftvernek” tekinthetők, melyekre szintén szükség van a civil kontroll rendszerének sikeres müködtetéséhez (Bland 2001, 525526).

Bland elméletének egyik fő megállapítása, hogy a civil-katonai kapcsolatok egyszerre vetnek fel információs és kontroll problémát, valamint, hogy aszimmetriahelyzettel jellemezhetőek. Lényeges megemlíteni, hogy a szerző egymástól elkülönült, de nem szigorúan elhatárolt civil és katonai szféra fogalommal dolgozik, 
mely megítélésem szerint jobban tükrözi a valóságot, mint akár Huntington szigorú elhatárolása, akár Schiff (lásd alább) „fúziós” elképzelése. A rezsimelmélet felhasználása kifejezetten innovatívnak tekinthető, mely alkalmas lehet az időbeli változások követésére, valamint a helyi sajátosságok bevonására. Szintén értékelendő az elmélet azon ambíciója, hogy (kísérletet téve a korábbi elméletek Amerikacentrikusságának kiküszöbölésére), bármely országban, valamint a politikai berendezkedéstől függetlenül alkalmazható legyen.

A közgazdaságtudományból származó megbízó-ügynök modellt elsőként Avant (1998) és Feaver $(1998,2003)$ alkalmazta a civil-katonai kapcsolatok témakörére. Mindkét szerző számára a politikusok és a katonai vezetők viszonyában meglévő információs aszimmetria helyzet, valamint a hatáskörök delegálásának problémája áll a vizsgálat középpontjában. A megbízó-ügynök kapcsolatot ebben az esetben olyan, a civil vezetők és a katonai vezetők közötti kapcsolatként definiálhatjuk, mely hierarchikus jellegü, és hatáskör-átruházást (delegálás) foglal magában. Mivel a katonai hivatás speciális szakismereteket követel meg, és ezen ismeretek leginkább a katonaság (közelebbről a tisztikar) birtokában vannak, a politikusok által szükségszerűen a hatáskörök és a feladatok delegálására van szükség. A delegálás alkalmával viszont szükségszerüen felmerül a kontroll és a morális kockázat problémája is. A kérdés tehát az, hogy a hatáskörök milyen mértékü delegálása, valamint a felügyelet milyen mértéke felel meg leginkább a megbízók (a civil politikai vezetés) céljainak. Tehát más szavakkal: noha a civilek számára a delegálás előnye, hogy a hadsereg operatív irányítását szakértő kezekbe helyezheti, de a hátrány az a dilemma, hogy vajon a katonai vezető a civilek érdekeit fogja képviselni vagy a saját érdekeit akarja majd előre mozdítani (Feaver 1998, 408-409, Sowers 2005, 388-389)? Feaver szerint ezen komplex viszonyrendszert játékelméleti megközelítésben lenne legcélszerübb szemlélni. Egy ilyen modell feltárja a civilek és a katonák közötti kapcsolat „mikroalapjait” (microfoundations), melyet az exogén tényezőkre épülő modellek (mint például Huntingtoné és Janowitzé) nem vettek kellően figyelembe (Feaver 1998, 408). Feaver alapmodellje egy kétszereplős játékot feltételez, ahol a civil és a katonai szereplők is „,egységesek”. A modell tehát feltételezi a hatáskörök katonákhoz delegálását, azonban az egyik változót az ezen delegálási viszony feletti civil ellenőrzés mértéke jelenti. A nagyobb mértékü ellenőrzés szükségszerüen költségekkel jár: ezek részben anyagiak, részben politikai 
jellegủek (Feaver 1998, 407-409). A katonák a civilek döntésére válaszul vagy engedelmeskednek (work), vagy pedig kibújnak (shirk) a civilek által adott utasítás alól. Lényeges ezen a ponton a használt fogalmak definiálása: Feaver szerint engedelmeskedésnek azt tekintjük, ha a katonák teljesítik, amire a civilek őket utasították, és az utasítást úgy és olyan módon teljesítik, hogy az a civilek hadsereg feletti elsődlegességét (civilian superiority) ne vonja kétségbe. Ezzel ellentétben, „kibújásról” vagy „kitérésről” akkor beszélünk, ha a katonák az utasítást nem teljesítik, vagy azt olyan módon teljesítik, hogy az a civilek elsődlegességét gyengíti, vagy kétségbe vonja (Feaver 1998, 409-410). Mitől függ a hadsereg döntése? Feaver úgy érvel, hogy alapvetően két tényező játszik ebben szerepet: az, hogy mekkora a különbség a civil és a katonai vezetés preferenciái között, és hogy a katonák megítélése szerint mekkora az esélye a „kibújás” esetén - a civilek részéről bekövetkező szankciónak. Egyfelől nem biztos, hogy a „kibújást” a civilek mindig felismerek, valamint másfelől a felismert „kibújás” nem jár automatikusan szankcióval (Feaver 1998, 409-410). A két szereplö lehetséges döntései (civilek: ellenőriz, nem ellenőriz, katonák: engedelmeskedés, „kibújás”) alapján a szerző modelljében összesen négy lehetséges kimenet szerepel. Az egyes kimenetekhez formális-matematikai feltételek írhatók fel, azonban ezek a játékelméleti értelemben egyenértékü egyensúlyi feltételek szakpolitikai értelemben nem egyenértékűek. Egyes egyensúlyi helyzetek a civil és katonai szféra közötti konszenzusos, mások pedig konfliktusos helyzetet feltételeznek (Feaver 1998, 414-415). Az elözőekben felvázolt paraméterek értékét a szerző szerint általában nehéz pontosan meghatározni, azonban közelítő vagy „durva” becslések adhatók rá. Feaver szerint a civilek általi ellenőrzés költségei, illetve az általuk alkalmazott szankciók valószínüsége határozható meg a legkönnyebben (Feaver 1998, 415-416, 419). Az ellenőrzés számszerüsíthető anyagi költségei mellett a politikai költségek az adott társadalom és politikai elit fenyegetés-percepcióitól is függenek. Ha a fenyegetés erösebb, a politikai vezetők számára „megéri” a beható ellenőrzés mellett dönteni, hisz politikai tőke kovácsolható ebből a döntésből. A szankció valószínűsége tulajdonképpen a civil és katonai szféra egymáshoz viszonyított politikai erejének függvénye. Így függhet például attól, hogy a kormányzaton belül milyen erős a védelmi miniszter politikai pozíciója, vagy a „kibújást” elkövető katonai vezető a közvéleményben mennyire népszerü (Feaver 1998, 415-419). Deborah Avant a megbízó-ügynök elemzési keretet kiterjesztve arra a következtetésre jut, hogy azon 
politikai rendszerek esetében, amelyek a hatalmi ágak határozott vagy éles szétválasztására épülnek (pl. az USA), megosztott megbízó (divided principal) helyzettel állunk szemben, ellentétben a hatalmi ágak kevésbé határozott szétválasztására épülő politikai rendszerek (pl. Nagy-Britannia) egységes megbízójával (unitary principal). A katonai szereplő szempontjából a megkülönböztetés annyiban releváns, hogy előbbi esetben jobb lehetőségek kínálkoznak számára a saját szempontjai érvényesítésére, mint utóbbiban. Ez utóbbi esetben, ha az egyes hatalmi ágak (például az elnök és a törvényhozás) között nézetkülönbségek vannak, a katonai vezetőknek lehetőségük van a politikusok egyik vagy másik csoportja mellett állást foglalni (Avant 1998, 383, Avant 1994, idézi Sowers 2005, 405-406).

Thomas S. Sowers (2005) ezt a gondolatmenetet fejleszti tovább és alkalmazza egy, a jelenkori fegyveres erők szempontjából igen releváns probléma, a nemzetközi és koalíciós müveletek feletti civil felügyelet és irányítás elemzésére. Az ilyen helyzeteket az különbözteti meg a „hagyományos” civil-katonai viszonyoktól, hogy a katonai erők felügyelete és irányítása általában több civil szereplő között oszlik meg (a szerző esettanulmányként a KFOR-t vizsgálja), valamint, hogy a katonák nem állami politikai szereplőkkel (nemzetközi szervezetek) is megbízó-ügynök viszonyban állnak. Sowers három ponton finomítja a feaveri modellt: egyrészt bevezeti a több megbízó-egy ügynök helyzeteket, másfelől figyelembe veszi az egyes nemzeti civil-katonai kapcsolatok hatását az ügynökök reakcióira. Emellett felveti az egymásba ágyazott megbízó-ügynök kapcsolatok lehetőségét, azaz a modell alkalmazhatóságát a civil és a katonai szférán belüli alárendeltségi és döntéshozatali viszonyokra. (Sowers 2005, 385-391). A megbízó ellenőrzésre vonatkozó döntése, valamint az ügynök reakciója alapján a szerző négyféle helyzetet vázol fel: „meghatározott” (specified), és a „beleértett” (implied), típusú kapcsolatok esetén az ügynök együttmüködik a megbízóval, ezzel szemben a „dacoló” (defied) valamint az „elutasító” (denied) kapcsolatokat az jellemzi, hogy az ügynökök törekszenek a megbízói utasítás vagy ellenőrzés alóli „kibújásra” (Sowers 2005, 400-403). Sowers mint említettem, Feaver modelljét fejlesztette tovább a több megbízó-egy ügynök helyzetek bevonásával, ugyanakkor két kritikát is megfogalmazott az eredeti modellel szemben. A nemzeti civil-katonai sajátosságok hatásának elemzésével arra kívánt rámutatni, hogy noha a megbízó-ügynök elmélet jó eszközt kínál a civilkatonai kapcsolatok komplex elemzésére, ennek minden részlete nem írható le a 
Feaver által javasolt institucionalista keretek között (Sowers 2005, 403-404). A szerző bírálta Feaver azon implicit feltételezését is, mely szerint a Sowers által beleértettként azonosított civil-katonai viszonyt tartotta ideálisnak. Ez utóbbi nagy vonalakban megfelelne Huntington fentebb már ismertetett „objektív civil kontroll” fogalmának. Mint Sowers kifejti, a nemzeti sajátosságok hatásának bevonása azt is segít megmagyarázni, hogy a „beleértett” kapcsolati típus ideálisnak feltételezése korántsem általános (Sowers 2005, 403-404).

Bland (2006) fő ellenvetése a megbízó-ügynök elmélettel kapcsolatban, hogy az alapvetően a végrehajtó hatalom ügynökének tekinti a hadsereget, de a tisztek adott körülmények között olyan szakembereknek tartják magukat, akik bizonyos jogköröket (főleg a belső parancsnoklás) saját jogon gyakorolhatnak. Emiatt Bland álláspontja szerint lehetséges, hogy a megbízó-ügynök elmélet csak különleges körülmények között alkalmazható a civil-katonai kapcsolatokra (Bland 2006, 120). José A. Olmeda a megbízó-ügynök modellel kapcsolatban azt a fó problémát emeli ki, hogy a civil és katonai szereplök nem mindig racionális választás alapján döntenek, illetve nem csak racionális tényezők játszanak szerepet döntésükben. A minden kétséget kizáróan jelen lévő normatív tényezőket ebben a modellben nem könnyü tehát mérni és meghatározni. A mérési problémák ugyanakkor a Feaver által kidolgozott indikátorok esetében is felmerülnek: ezek operacionalizálása esetenként igencsak nehézkes, valamint Olmeda szerint a modell elörejelzéseit az empirikus eredmények nem mindig támasztják alá. Maga Feaver is felhívta a figyelmet arra a tényre, hogy modellje a több-megbízó és több-ügynök szituációkban sokkal nehezebben múködik (Olmeda 2013, 65-66). Mint Olmeda megjegyzi, a demokráciának a katonai szféra engedelmessége szükséges, de nem elégséges feltétele, más szóval „a demokrácia többet igényel a civil-katonai kapcsolatoktól, mint pusztán engedelmességet” (Olmeda, 2013, 66).

Desch $(1999,8-9)$ álláspontja szerint a megbízó-ügynök modell túlzottan kötődik az Egyesült Államok politikai berendezkedéséhez, így nem biztos, hogy megbízhatóan alkalmazható más esetekre. Emellett, korlátozott magyarázó ereje miatt inkább tekinthető egy elemzési keretnek, mint egy átfogó elméleti modellnek.

Thomas C. Bruneau és Florina C. Matei (2013) a közpolitika-elemzésben is alkalmazott eredményesség és hatékonyság kérdésének bevonását javasolja a civilkatonai kapcsolatok vizsgálatába. Az általuk javasolt új modellben a kontroll 
aspektus mellett a biztonsági erők eredményességének, valamint az erőforrások hatékony felhasználásának kérdését is bevonták az elemzésükbe. A szerzők érvelése szerint a fejlett demokráciákban a kontroll vizsgálata önmagában nem elegendő a civil-katonai kapcsolatok kielégítő elméleti modelljének megalkotásához, ehhez a kérdés más dimenzióit is vizsgálni kell. (Bruneau 2013, 18-19). A korábbi elméletek fogyatékosságai e gondolatmenet alapján nem merülnek ki a kontroll aspektusára korlátozottságban: korlátozottan vagy egyáltalán nem veszik figyelembe a reguláris hadseregen kívüli biztonsági szervezeteket (rendőrség, titkosszolgálat), valamint a fegyveres erőknek az elmúlt évtizedekben előtérbe kerülő, a tradicionális területvédelmi vagy honvédelmi funkciótól eltérő szerepeit (Bruneau 2013b, 23-26). Ilyen értelemben tehát Bruneau és Matei fogalomhasználata közel áll Edmunds (2007) „biztonsági szektor” koncepciójához. Az elmélet nem veti el a „klasszikus” kontroll jelentőségét, amely különösen nagy az újonnan demokratizálódó országokban, ahol korábban például katonai rendszer volt uralmon, vagy, mint a volt Szovjetunióban és egykori szatellit államaiban, ahol a reguláris hadseregtől eltérő biztonsági szervezetek (pl. rendőrség, munkásőrség, titkosszolgálat) is tevékenyen részt vettek az autoriter politikai berendezkedés fenntartásában (Matei 2013, 30).

A civil kontroll fogalmát a két szerző három további dimenzióra bontja: az intézményi kontroll, illetve a felügyelet és elszámoltathatóság eszközei, valamint a demokratikus kontrollt elősegítő szakmai normák jelenléte a fegyveres erőknél. Az intézményi kontroll eszközeit olyan klasszikus intézményi megoldások alkotják, mint a civil vezetésü védelmi minisztérium, a politikai vezetés monopóliuma a védelmi kiadások meghatározásában vagy a fegyveres erő alkalmazásában. Azonban emellett szükséges a politikusok által meghatározott szakpolitikai irányvonal megvalósításának figyelemmel kísérése is, amit jól működő demokráciákban a politikai vezetés mellett a civil és a tudományos szféra, valamint a média és a közvélemény is ellát. Végezetül a demokratikus kontrollt elősegítő szakmai normák elterjesztése a szakpolitikusok által kialakított, ezt szolgáló toborzási, képzési és kiképzési rendszerek útján történhet (Matei 2013, 30-32).

A demokratikus civil-katonai kapcsolatok lényeges eleme, hogy a hadsereg és a tágabban értelmezett biztonsági szektor szereplői mennyire „eredményesen” látják el feladatukat. Mivel az eredményesség -különösen pedig a fegyveres szervezetek honvédelmitől eltérő feladatai esetében - nehezen mérhető, ennek érdekében a szerzők három, jobban körülhatárolható szempontot javasolnak. Az első a feladat 
eredményes ellátásához szükséges stratégiák és doktrínák jelenléte, a második az ezt elősegítő intézményrendszer, a harmadik pedig az ehhez kapcsolódó források: mind anyagi, mind pedig humán erőforrások, valamint politikai támogatás (Matei 2013, 31-33). A biztonsági szektor szereplőinek nem kellően eredményes működése a civil kontroll érvényesülését is korlátozhatja, valamint a biztonsági erők legitimitását is befolyásolhatja a társadalom szemében (Matei 2013, 31-33). A szerzők helyesen ismerik fel, hogy noha a területvédelem a fegyveres szervezetek által jelenleg a legritkábban ellátott funkció, a tervezés során mégis ez szerepel a legnagyobb hangsúllyal. Ez azonban esetenként ürügyként is értelmezhető a politika és a közvélemény részéről annak érdekében, hogy a fenyegetés csekély voltára hivatkozva csökkentsék a biztonsági szektorra fordított forrásokat, amely viszont a többi, a gyakorlatban jelentősebb feladat eredményes ellátását is nehezíti (Matei 2013, 33).

A Bruneau és Matei által kialakított elméleti keret erősségei közé sorolható a használt biztonságfogalom kellően tág jellege, a biztonsági szervezetek tevékenységében és müködésmódjában a 21. században egyre inkább előtérbe kerülő új elemek (transznacionális fenyegetések, intézmények közötti szorosabb együttmüködés, hadviseléstől eltérő új feladatok) hangsúlyos figyelembe vétele. Szintén az elmélet javára írható az empirikus, esettanulmányokon való tesztelést megkönnyítő szempontrendszer kidolgozása. Az elmélet hiányosságaként jelölhető meg (bár ez jelen disszertáció szempontjából nem releváns), hogy nehézkesen alkalmazható a civil-katonai kapcsolatok elemzésére nem demokratikus államokban, valamint, hogy a hatékonysági dimenzió operacionalizálása nem történt meg megfelelően (ezt azonban maguk a szerzők is elismerik, ld. Bruneau 2013c, 39-47). Emellett megítélésünk szerint a két szerző nem határozta meg világosan azon oksági tényezőket sem, melyek a kontroll, eredményesség és hatékonyság mértékét befolyásolják.

Eltérően a főként intézményi alapú magyarázatoktól, a Rebecca L. Schiff (1995, 2009) által kidolgozott egyetértési vagy konkordancia-elmélet a kultúra, valamint a normák szerepére épít. Schiff megkérdőjelezi, hogy a civil és katonai szférák minden esetben határozottan elkülönültek, és azon az állásponton van, hogy a civil-katonai kapcsolatok különféle mintái (így az elkülönülés mértéke) a hadsereg, a politikai elit és a tágabban vett „társadalom” közötti megegyezés eredménye (Schiff 1995, 7-8). A 
szerző szerint az eddig elméleteknek az a fő problémája, hogy azokat túlzottan az Egyesült Államok intézményrendszerét, történelmi, társadalmi hátterét figyelembe véve alakították ki, hogy azt feltételezik, hogy a civil és a katonai szférák minden esetben elkülönültek, valamint, hogy az intézményi aspektus mellett teljesen elhanyagolják a kulturális vonatkozásokat. Az általa javasolt konkordancia-elmélet viszont az intézményi és kulturális aspektusok integrálása révén relevánsabb magyarázatot nyújthat különböző intézményes és történelmi, társadalmi körülmények között a civil-katonai kapcsolatok müködésére, valamint a civil kontroll feltételeire. Az elmélet gondolatmenete szerint amennyiben a fent említett három szereplő sikeres megegyezésre jut négy kulcsfontosságú kérdésröl, az hozzájárul a civil kontroll megszilárdításához, és jelentősen csökkenti a hadsereg politikai beavatkozásának lehetőségét (Schiff 1995, 8-11).

A figyelembe veendő négy kérdés Schiff szerint a tisztikar társadalmi összetétele, a védelem- és katonapolitikai döntéshozatal módja (különös tekintettel a védelmi költségvetés meghatározásának folyamatára), a toborzás módja (sorozott vagy önkéntes), valamint az ún. „katonai stílus” - azaz az adott hadsereg sajátosságai. Ily módon tehát, érvel Schiff, a konkordancia-elmélet a párbeszédre, a megegyezésre és a közösen kialakított értékekre épül, egy ilyen megegyezés létrejötte esetén pedig jelentősen csökken a hadsereg politikai beavatkozásának lehetősége. Továbbá, ez az elméleti keret alkalmas arra, hogy különböző történelmi, társadalmi körülmények, valamint intézményrendszer mellett is magyarázatot adjon arra a kérdésre, hogy hogyan biztosítható a szilárd civil kontroll a fegyveres erők felett (Schiff 1995, 12 16).

A konkordancia-elmélettel kapcsolatos korai kritikák egyike, hogy a Schiff által bevezetett „konkordancia” fogalom alapvetően nem különbözik Huntington „szubjektív kontroll” és „civil-katonai fúzió” fogalmaitól (Wells 1996). Feaver (2006, 106-107) pedig arra mutat rá, hogy tulajdonképpen Schiff sem vitatja a civil és katonai szféra legalább elméletileg elkülönített voltát, amit az is mutat, hogy a katonaságot, a politikai vezetést és a társadalmat különálló csoportként kezeli. Mint Feaver kifejti, noha a gyakorlati konvergencia igenis megvalósul a két szféra között, legalábbis elméleti-analitikus értelemben szükség van elkülönítésükre. Egyes szerzők szerint eltúlzott a hadsereg társadalmi reprezentativitásának jelentősége is: empirikus vizsgálatok alapján sem a Huntington által előre jelzett negatív, sem a más szerzők által várt pozitív hatások nem származtak a hadsereg társadalmilag reprezentatívabbá 
tételéböl. Azaz, ha egy hadsereg társadalmilag reprezentatívabb, ettől valószínüleg nem lesz kevésbé hatékony, de nem lesz a politikai beavatkozásra sem kevésbé hajlamos (Avant 1998, 382). Avant $(1998,382)$ arra hívta fel a figyelmet, hogy a konkordancia-elmélet már csak azért sem alkalmas a stabil civil kontroll feltételeinek meghatározására, mert a hadsereg nem fog beavatkozni a politikába, ha preferenciái e nélkül is mindig érvényre jutnak.

A megbízó-ügynök elméletből ismeretes a megbízó-ügynök viszony megfordulásának (agency reversal) jelensége, melynek lényege, hogy az általa birtokolt információ és szaktudás révén az ügynök képes lehet arra, hogy megszerezze az ellenőrzést az adott ügy felett, és hogy saját preferenciáit juttassa érvényre. Így a megbízó preferenciái tulajdonképpen az ügynök preferenciáit fogják tükrözni. A konkordancia-elmélet, így Avant, nem alkalmas arra, hogy kimutassa ezt a jelenséget. A konkordancia-elmélet érdemei között említhető, hogy megpróbál túllépni a „professzionalizmus” huntingtoni fogalmán, és felismeri, hogy egyes korábbi elméletek túlzottan az Egyesült Államok viszonyaira szabottak, s ezért más országok vizsgálatára korlátozottan alkalmasak. A fentebb említett kritikákon túl viszont problematikus az intézményi aspektus „elmosódása”, „háttérbe szorulása”. A kulturális, történelmi háttér fontosságához ugyan kétség sem fér, azonban a civil kontroll szempontjából szükséges feltételezni, hogy léteznie kell egy olyan intézményi szerkezetnek, melyet alapvetően a civilek alakítottak ki. Mint a rezsimalapú megosztott felelősségi elmélet példája mutatja, ez önmagában nem zárja ki azt a felvetést, hogy a civilek által kialakított struktúrák sikeres müködéséhez a katonai vezetés együttmüködésére is szükség van (Bland 1999, 13-15, 16-17).

A Michael C. Desch (1996, 1999) nevével fémjelzett modell a nemzetközi kapcsolatok elméletének strukturális realista irányzatához köthető. Fő jellegzetessége a külső körülmények hangsúlyos figyelembe vétele a civil-katonai kapcsolatokban. Az elmélet két alapkategóriája a strukturális fenyegetés-környezet (structural threat environment), valamint két egymáshoz kapcsolódó fogalom, a katonai doktrina és a hadsereg elsődleges küldetése vagy missziója. A misszió vagy küldetés két szempont szerint osztályozható: a szerző megkülönböztet külső vagy belső, illetve katonai vagy nem katonai (például rendfenntartás) jellegü missziókat. A doktrínát, melyet alapvetően a politikai vezetés határoz meg, röviden úgy jellemzi Desch, hogy ez a "szoftver" ami a hadsereg "hardverén" fut. (Desch 1996, 13-14) 
A doktrína azt határozza meg, hogy milyen katonai erőforrásokat hol és hogyan kell a fegyveres erőknek felhasználni. (Desch 1999, 17) A strukturális fenyegetéskörnyezet azt fejezi ki, hogy az adott időszakban milyen irányú (belső vagy külső) valamint milyen szintü (alacsony vagy magas) fenyegetések érik az adott államot. Az elemzés szempontjából az államot Desch három szereplöre bontja: a kormányzat, a fegyveres erők és a "társadalom".

Az elmélet alapgondolata szerint a legtöbb esetben a fenyegetés-környezet határozza meg elsődlegesen a civil-katonai kapcsolatokat. Az ilyen helyzeteket a szerző strukturálisan meghatározott (determinált) helyzeteknek nevezi. A strukturálisan nem determinált helyzetekben a strukturális jellegű változók (a fenyegetés-környezet) nem adnak kellő magyarázatot, ekkor egyéb tényezőket is be kell vonni az elemzésbe, ezek egyike lehet a katonai doktrína, illetve a hadsereg domináns küldetése vagy missziója (Desch 1999, 6-7, 11-13). A fenyegetés-környezet több területen befolyásolja az állam magatartását: a politikai vezetés jellege, a katonai intézmények jellege és természete, az állami intézmények kohéziója, a civil kontroll módszere, valamint a civil és katonai világnézet és szemléletmód közötti hasonlóságok és különbségek (Desch 1999, 12-13). Desch azonban ezek nagy részét közbülső változóknak tekinti, a civil kontroll mértéke, mint függő változó meghatározásában, független változóként pedig mint említettem, a strukturális fenyegetés-környezet vonja be a vizsgálatba.

Hogyan definiáljuk a civil kontroll mértékét? A szerző felhívja a figyelmet a "nincs puccs nincs problémának" (no coup no problem) nevezett gondolkodás fogyatékosságaira, azaz amikor a civil kontroll mértékét vagy a civil-katonai kapcsolatok "harmonikus" voltát kizárólag a katonai hatalomátvétel -vagy annak kísérlete- előfordulásában vagy hiányában határozzuk meg. A civil-katonai problematika lényegét (Huntingtonhoz hasonlóan) a szakértő és a politikus viszonyában látja, és ennek nyomán a müködő vagy szilárd civil kontrollt akként definiálja, hogy amikor a civil és katonai vezetők preferenciái különböznek, az előbbiek álláspontja érvényesül (Desch 1999, 3-4, 11). Míg a külső fenyegetések hatása viszonylag egyértelmü, a belső fenyegetések esetében egy további distinkciót tart szükségesnek aszerint, hogy azok a hadsereget mennyiben érintik. Ha az adott belső fenyegetés a hadsereg ellen nem irányul, akkor ez nincs hatással a civil kontrollra. A hadsereget érő „fenyegetések” a biztonsági fenyegetéseken túlmenően lehetnek olyan hatások is, amelyek például a hadsereg belső szervezeti kohézióját 
vagy egyenesen intézményes létét érintik (Desch 1998, 392). Természetesen a fenyegetések egy része szubjektív, azaz hatásuk attól is függ, hogy a szereplők hogyan értelmezik azokat, illetve milyen fontosságot tulajdonítanak nekik. A katonai doktrínák ennek megítélésében is szerepet játszanak (Desch 1999, 12-13). Desch épít a Huntington által bevezetett objektív és szubjektív civil kontroll fogalomra is, ugyanakkor megítélése szerint Huntington nem részletezi kellően, mitől függ az, hogy a civil vezetés egy adott helyzetben objektív vagy szubjektív civil kontrollt alkalmaz e, valamint a nemzetközi környezet hatását sem tisztázza pontosan. A szerző szerint a civil-katonai kapcsolatok eddigi elméletei viszonylag keveset foglalkoztak a külső környezet szerepével. A külső tényezők és a civil-katonai kapcsolatokra vonatkozó két klasszikus feltevés Harold Lasswell és Stanislav Andreski nevéhez füződik. Lasswell szerint akkor gyengül a fegyveres erők feletti civil kontroll, ha az állam jelentős külső fenyegetésnek van kitéve. Ez az úgynevezett "kaszárnyaállam" hipotézise. Andreski ezzel ellentétben azon az állásponton van, hogy a külső fenyegetés hiánya, és a hadsereg ebből következő "tétlensége" vezet a civil kontroll meggyengüléséhez (Desch 1996, 12-13 és Desch 1999, 1-2).

Magas külső és alacsony belső fenyegetettség esetén a szerző szerint a legkedvezőbbek a szilárd civil kontroll lehetőségei. Ekkor valószínübb a katonai ügyek vitelére alkalmas civil vezetők jelenléte a kormányzatban, a társadalom és a politikai intézmények kohéziója erős ("rally the flag" effektus), valamint ugyanez mondható el a hadseregröl, amely várhatóan külső orientációt vesz fel. A civil politikusok objektív civil kontroll eszközöket alkalmaznak, és várhatóan egymással összeegyeztethető a civil és a katonai felfogás a nemzetközi kapcsolatokról és a katonai erő alkalmazásáról. Ily módon tehát a szerző cáfolja Lasswell "kaszárnyaállam" hipotézisét. Esettanulmányokon tesztelve fenti feltevéseit, Desch demokratikus (USA) valamint nem demokratikus (Szovjetunió) példát is talált a hidegháború időszakából, melyek megerősítik azokat (Desch 1999, 13-14, 115-116). Az alacsony külső és magas belső fenyegetettség a leginkább kedvezőtlen helyzet a szilárd civil kontroll szempontjából. Ebben az esetben fennáll a hadsereg a civil vezetők általi "átpolitizálásának" veszélye, valamint az elsődlegesen belülről érkező fenyegetések is felerősítik a hadsereg politikai beavatkozásának kockázatát. Mindezt súlyosbíthatja, ha az érvényes katonai doktrína is elsősorban "belső" orientációjú, azaz például a rendfenntartó feladatokat helyezi előtérbe. A történelmi példák elsősorban a hidegháború alatti Latin-Amerikából- ugyanakkor arra utalnak, hogy 
hatalomra kerülés után megrendülhet a hadsereg belső kohéziója: ilyen helyzetben a katonai rendszer fennmaradására különösen nagy fenyegetést jelent, ha egy háborút is meg kell vívnia. Ebből a szempontból tanulságos példát kínál az argentin katonai rezsim összeomlása a Falkland-háborúban elszenvedett vereség következtében (Desch 1996, 18-19, Desch 1999, 14-15, 119-120).

A strukturális elmélet csak korlátozottan alkalmas a civil kontroll szintjének előrejelzésére az olyan helyzetekben, amikor a külső és a belső fenyegetettség mértéke egyaránt magas vagy egyaránt alacsony. Alacsony külső és belső fenyegetettség esetén a szerző szerint csak alacsony szintü civil-katonai konfliktus várható, ami inkább koordinációs problémákat nem pedig engedetlenséget jelent. Ha mind a külső, mind pedig a belső fenyegetettség magas, Desch előrejelzése szerint, a külső fenyegetés miatt a katonaság belső kohéziója várhatóan erős lesz, ezért noha várhatóak civil-katonai konfliktusok, de jóval kevesebb, mint az alacsony külső és magas belső fenyegetettség körülményei között (Desch 1999, 15-17).

Ezen, strukturálisan nem meghatározott esetekben egyéb tényezőket is figyelembe kell venni a civil kontroll erősségének megítélésében, ezek egyike a doktrína, a másik pedig a hadsereg küldetése vagy missziója. Egy dominánsan külső misszió esetén a szerző szerint a civil kontroll szilárdabb lesz, mint abban az esetben, ha a hadsereg fő feladata a belső fenyegetések elhárítása (Desch 1996, 13-14, Desch 1998, 390-395). A biztonsági tanulmányok szakirodalmában jelentős figyelmet kapott a katonai doktrínák külső következményeinek vizsgálata, de a szerző szerint eddig nem vizsgálták megfelelően azt a kérdést, hogy egy adott államon belül milyen következményei lehetnek az állam által elfogadott katonai doktrínának. A doktrína alapvetően három csatornán keresztül tud hatást gyakorolni a civil-katonai kapcsolatokra. Egyfelől, döntően befolyásolja a katonai szervezetek belső struktúráját. Másodsorban, hatással van a fegyveres erők belső szervezeti kultúrájára és identitására is, mely abból a szempontból jelentős, hogy kialakult-e, és ha igen, mennyire erős a civil kontrollnak való alárendelődés hagyománya a katonaságon belül. Harmadrészt pedig, a doktrína befolyásolja a katonai vezetők szemléletmódját a nemzetközi kapcsolatokról és ezen belül az erő alkalmazásáról. Desch Huntingtonra hivatkozva a civil és a katonai vezetők világképe közötti különbségekben látja a civil-katonai "súrlódások" egyik lehetséges forrását. (Desch 1999, 17-19, Desch 1998, 395-396) A modell főbb feltevéseit az 1. számú táblázat összegzi. 
1. táblázat: Michael C. Desch strukturális realista modelljének főbb feltevései

\begin{tabular}{|c|c|c|c|c|c|c|c|}
\hline $\begin{array}{l}\text { Külső } \\
\text { fenyegetés }\end{array}$ & $\begin{array}{l}\text { Belső } \\
\text { fenyegetés }\end{array}$ & $\begin{array}{l}\text { A hadsereg } \\
\text { orientációja }\end{array}$ & $\begin{array}{l}\text { A civilek } \\
\text { belső } \\
\text { kohéziója }\end{array}$ & $\begin{array}{l}\text { A } \\
\text { hadsereg } \\
\text { belső } \\
\text { kohéziója } \\
\end{array}$ & $\begin{array}{l}\text { A civil } \\
\text { kontroll } \\
\text { várható } \\
\text { formája } \\
\end{array}$ & $\begin{array}{l}\text { A civil kontroll } \\
\text { várható szintje }\end{array}$ & $\begin{array}{l}\text { Jellemző } \\
\text { történelmi } \\
\text { példák }\end{array}$ \\
\hline Magas & Alacsony & Külső & egységes & egységes & objektív & Erös & $\begin{array}{l}\text { USA és } \\
\text { Szovjetunió a } \\
\text { hidegháború } \\
\text { alatt }\end{array}$ \\
\hline Alacsony & Magas & Belső & megosztott & egységes & szubjektív & Gyenge & $\begin{array}{l}\text { Argentína a } \\
\text { hatvanas- } \\
\text { hetvenes } \\
\text { években }\end{array}$ \\
\hline Magas & Magas & $\begin{array}{l}\text { nem } \\
\text { meghatározott }\end{array}$ & megosztott & egységes & $\begin{array}{l}\text { nem } \\
\text { meghatározott }\end{array}$ & Közepes & $\begin{array}{l}\text { Németország } \\
\text { 1914-1918, } \\
\text { Franciaország } \\
1954-1962 \\
\end{array}$ \\
\hline Alacsony & Alacsony & $\begin{array}{l}\text { nem } \\
\text { meghatározott }\end{array}$ & megosztott & megosztott & $\begin{array}{l}\text { nem } \\
\text { meghatározott }\end{array}$ & $\begin{array}{l}\text { Erős (de } \\
\text { gyengébb mint } \\
\text { az első esetben) }\end{array}$ & $\begin{array}{l}\text { USA a } \\
\text { kilencvenes } \\
\text { években } \\
\end{array}$ \\
\hline
\end{tabular}

Forrás: saját szerkesztés Michael M. Desch: Civilian Control of the Military, the Changing Security Environment. Johns Hopkins University Press, Baltimore, 1999, 16-20, 116. old. alapján

A szerző szerint az "ideális" civil-katonai kapcsolatok kialakulását, valamint a szilárd civil kontrollt több tényező is segítheti. Az egyik, ha a hadsereg elsődleges küldetése külső és "tradicionális" katonai jellegü. A belbiztonsági feladatok, valamint a terrorelhárítás elvonják a hangsúlyt a tradicionális katonai feladatokról és a civil kontroll szempontjából sem ideálisak. Ugyanakkor érdemes megjegyezni, hogy a szerző szerint ez nem vonatkozik a fegyveres erők katasztrófavédelmi célú bevetésére. A doktrína akkor megfelelő, ha egyszerre felel meg a nemzetközi helyzet kihívásainak és támogatja a szilárd civil kontroll fenntartását. Desch szerint az újonnan demokratizálódó országokban ezt segítheti a haderő nemzetközi béketámogató müveletekre történő felkészítése és ezekben való aktív részvétele. Más államok és nemzetközi szervezetek is játszhatnak pozitív szerepet a civil és demokratikus kontroll tradícióinak megteremtésében, azonban ez a befolyást a szerző limitáltnak tekinti (Desch 1996, 25-26, Desch 1999, 120-122).

A Desch által kidolgozott strukturális realista elmélet legföbb erőssége, hogy figyelembe veszi a külső hatásokat a civil-katonai kapcsolatok, valamint a haderő feletti civil kontroll vizsgálatában. Teljes mértékben helytállónak tartom azt a gondolatot, hogy a külső és belső fenyegetettség döntő befolyást gyakorol a civilkatonai kapcsolatok területén is, azonban megítélésem szerint a vizsgálandó külső tényezők nem szűkíthetők le a fenyegetésekre. 
Maga Desch is említi a szocializációt, mint azon csatornák egyikét, amelyen keresztül a állam magatartását a külső környezet befolyásolhatja, ugyanakkor ennek bővebb kifejtése nem jelenik meg részletesen a modellben. Az egyszerüségre törekvés ugyanakkor helyenként túlzott leegyszerüsítésekhez vezetett, így álláspontom szerint nem tekinthető egységes, monolitikus aktornak sem a hadsereg, sem pedig a „kormányzat” és a „társadalom”. Maga a modell is számol azzal, hogy a hadsereg egyes esetekben „megosztott”, míg más esetekben „egységes” lesz. Mindemellett az elmúlt másfél évtized konfliktusai, így például a felkelők elleni hadviselés (counter-insurgency) Irak és Afganisztán kapcsán tapasztalható újabb felértékelődése fényében nem tartom praktikusnak a hadsereg feladatainak szigorú szétválasztását „katonai” és „,nem katonai” aspektusokra. Ezen túlmenően például a közelmúlt terrorellenes tevékenységében több esetben sor került a fegyveres erők belföldi (rendfenntartó célú) szerepvállalására is, mely a haderő demokratikus kontrollja terén szilárd hagyományokkal bíró államok (például Belgium és Franciaország) esetében nem befolyásolta negatívan a civil-katonai kapcsolatokat. 


\section{Civil-katonai kapcsolatok a szovjet típusú pártállami rendszerekben}

\subsection{A civil-katonai kapcsolatok általános jellemzői a pártállami rendszerekben}

Az előző fejezetekben bemutatott elméletek elsődlegesen a demokratikus berendezkedésű országokra vonatkoznak. A következőkben arra teszek kísérletet, hogy bemutassam azokat a föbb elméleti magyarázatokat, melyek a kommunista rendszerek esetében születtek a civil-katonai kapcsolatok, illetve a fegyveres erök politikai szerepének vizsgálatára. Jelen fejezetben előbb röviden áttekintem a kommunista berendezkedésű országok azon sajátos jellemzőit, melyek a civil-katonai kapcsolatok szempontjából relevánsak, majd megvizsgálom az ebben a témában született fontosabb elméleti magyarázatokat. A témával foglalkozó szakirodalom legnagyobb részt a Szovjetunió esetével foglalkozik, Moszkva kelet-közép európai szatellitjei, valamint a többi kommunista állam (így például Jugoszlávia, Kína, Vietnam) jóval kevesebb figyelmet kaptak (Barany 1993, 7). A 4. fejezetben fogok részletesebben foglalkozni a civil-katonai kapcsolatokkal, valamint a hadsereg politikai szerepével az egykori Jugoszláviában, mely, mint látni fogjuk, mind a szovjet modelltől, mind pedig Moszkva közép-kelet-európai szatellitjeinek helyzetétől több tekintetben alapvetően különbözött.

A kommunista rendszereken belüli civil-katonai kapcsolatok egyik fö - de részben csak látszólagos - paradoxona, hogy noha ezen államok hadseregei nemcsak, hogy átpolitizáltak voltak, de különböző módon és mértékben, ezen államok politikai életében is részt vettek, ugyanakkor a kommunista rendszerek fennállása alatt nem került sor "teljesen konszolidálódott" kommunista berendezkedésű országban sikeres katonai hatalomátvételre (Perlmutter és LeoGrande 1982, 778).

A vonatkozó elméleti magyarázatok áttekintése előtt fel kell tenni azt a kérdést, hogy melyek a kommunista berendezkedésü országok a vizsgálat téma szempontjából egyedi jellegzetességei. Perlmutter és LeoGrande $(1982,780)$ alapján a civil-katonai kapcsolatok hagyományos elméletei két olyan feltételezéssel élnek, melyek a kommunista társadalmak esetében nem relevánsak: egyfelől, hogy világosan elkülöníthetők a civil és a katonai elitek, másfelől pedig, hogy a civil vagy a katonai elit, illetve esetleg mindkettő, magáénak vallja az apolitikus hadsereg alapelvét. Az állampártnak alkotmányos szinten is rögzített társadalmi vezető szerepe miatt az ilyen államokban a párt a szuverén, a fent említett társadalmi vezető szerepét a 
párton kívüli társadalmi szervezetek és intézmények (tömegszervezetek, az állami bürokrácia és a fegyveres erők) irányítása útján fejti ki. A hadsereg és a párt közötti kapcsolat az ilyen államokban esetenként konfliktusos. mivel a katonaság az egyetlen intézmény a kommunista rendszerekben, amely képes lenne erőszakkal megdönteni a párt hatalmát. A párt folyamatosan aggódott az ún. „,bonapartizmus” lehetősége miatt és különböző eszközöket keresett a hadsereg ellenőrzés alatt tartására. Ennek lehetséges formái a tisztogatásoktól, koncepciós perektől (a szovjet katonai elit lefejezése Sztálin alatt a 30-as évek végén) a katonai vezetés pártba való kooptálásáig, illetve különböző privilégiumok nyújtásáig terjedt (Barany 1993, 10). A valóságban a párt hegemóniájának mértéke attól függ, milyen hatékonyan tudja irányítani a párton kívüli szervezeteket és intézményeket. Perlmutter és LeoGrande szerint ennek egyik legfontosabb eszköze a „kettős szerepü” elitek kialakítása. Annak következményeként, hogy a pártelit és a párton kívüli intézmények elitje jelentős mértékben egybeesik, az elitkonfliktusok, legalábbis a rendszer felső szintjein, párton belüli konfliktusok formáját öltik (Perlmutter és LeoGrande 1982, 779). A szerzők szerint a kommunista rendszerekben a politika „vasháromszögének” elemei a párt, az államapparátus és a hadsereg, melyek a pártnak való politikai alárendeltség és a korlátozott intézményes autonómia komplex rendszerében kötődnek egymáshoz (Perlmutter és LeoGrande 1982, 778-779). Kolkowicz (1982, 122, 1982b, 233) és Barany (1993, 11-12) szerint az ilyen rendszerek lényeges jellemzője még a hatalmi utódlás intézményesített módjának hiánya: a kommunista rendszerekben sem a tradíció (mint például a dinasztikus utódlás esetében) vagy a jogi-alkotmányos előírások (mint a szabad választások esetében) nem szabályozza a hatalomban való utódlás kérdését. A kettős szerepű elitek kialakításán túlmenően a pártirányítást intézményes struktúrák is biztosították, a Központi Bizottság részeként müködő Politikai Főosztály, illetve a politikai tisztek rendszere révén. A pártkontroll részét képezte a titkosszolgálat aktív jelenléte is a fegyverek erők különböző szintjein (Barany 1993, 10-11).

Végezetül, a kommunista rendszerekben a hadsereg fó feladatai közé tartozott a klasszikus területvédelem mellett a rezsimvédelmi funkció is. Mivel a kommunista rendszerek mindegyike erőszakos úton került hatalomra, ezért azok társadalmi legitimitása legalábbis kérdéses volt. Ezért a hadsereg a rezsim fenntartásában is fontos szerepe játszott (Barany 1993, 6-7). Lényeges emellett megjegyezni, hogy ugyan a marxista-leninista ideológiában és a kommunista államok propagandájában 
is jelentős szerepet kapott az antimilitarizmus - egyebek mellett ezen államok békeszerető voltának és a fegyveres konfliktusok kapitalista, imperialista mozgatórugóinak hangoztatása által - az állampárt saját éthoszát, értékeit, stílusát, retorikáját és rituáléit nagy mértékben áthatotta a katonai jelleg (lásd pl. Kolkowicz 1982, 129 és Barany 1993, 8-9).

\subsection{EIméletek és viták}

A civil-katonai kapcsolatok úttörő szerzői - Samuel Huntington (1957) és Morris Janowitz (1964) - csak érintőlegesen foglalkoztak a kommunista államok civilkatonai kapcsolataival, valamint látásmódjukat az ún. totalitárius paradigma befolyásolta. Ez alapján mind a pártot mind pedig a hadsereget egységes, monolitikus szereplőnek tekintették, valamint a hadsereg egyirányú, pártnak való totális alárendelödését tételezték. Huntington szerint a párt fö eszköze a hadsereg kontrolljára az ideológiai indoktrináció illetve az annak soraiba történő „,penetráció”, a politikai tisztek rendszere és más hasonló technikák révén. Az ilyen államokban a civil-katonai kapcsolatokat tényleges vagy látens válság jellemzi, mivel a pártirányítás igénye konfliktusba kerül a tisztikar szakmai autonómiára irányuló igényével (Huntington 1957, idézi Herspring 1999, 561-562). A totalitárius modellt, illetve az erre épülő, Eric Nordlinger (1977) nevéhez köthető ún. penetrációs modellt a szakirodalomban számos bírálat érte. Általánosságban az állapítható meg, hogy ezen modell feltételezései történetileg csak a Szovjetunióban és ott is csak a sztálini időszak esetében igazolhatók. Barany $(1993,13)$ arra hívja fel a figyelmet, hogy a modell túlzottan merev, nem alkalmas a Szovjetunió fennállása során a civil-katonai kapcsolatok terén bekövetkezett változások magyarázatára és alacsony magyarázó erővel bír a kelet-közép európai szovjet szatellitállamok, valamint a Szovjetunión kívüli kommunista államok (Kína, Vietnam, Jugoszlávia) esetében is.

Roman Kolkowicz a szovjet hadsereget a pártállam keretei között létezö egyfajta sajátos érdekcsoportként azonosította, melynek prioritásai (így például a katonai és hadiipari kiadások magas szinten tartása) esetenként ellentétbe kerülnek a pártelit vagy a pártelit egyes csoportjai által képviselt prioritásokkal (Kolkowicz 1978, 22-23 és 1982, 115). 
A sztálini idők alárendeltsége után a hruscsovi és különösen a brezsnyevi időszakban tágult a hadsereg intézményes mozgástere. Ennek a szerző szerint számos oka jelölhető meg. Ide sorolhatjuk a Szovjetunió növekvő külpolitikai ambícióit (fokozódó szerepvállalás az ún. "harmadik világbeli" országokban a hatvanas évek közepétől), a pártvezetés "megkövülését", azt a tényt, hogy a hatalmi utódlás rendszerének megoldatlansága miatt a belső utódlása harcokban szerepet játszhat a fegyveres erők támogatása, valamint, hogy a szovjet hadsereg volt az egyetlen valódi "szövetségi" intézmény, mely így egyfajta "nemzetépítő" szerepet is játszott (Kolkowicz 1978, 12-13 és 1982, 116-117). Ezen felül megemlítendő még, hogy a hadviselés modernizációjával (például a stratégiai nukleáris fegyverek megjelenése) felértékelődött a speciális katonai szakértelem szerepe is. A hadsereg szerepe a Szovjetunióban tehát a szerző szerint három szakaszra osztható: a sztálini időszak alárendelődésével szemben a Hruscsov-érát a "növekvő interdependencia" és a "kooptálás" jellemezte, majd a brezsnyevi periódusban a "kifejlett interdependencia" körülményei között a "kölcsönös alkalmazkodás" határozta meg a párt és a hadsereg viszonyát (Kolkowicz 1982b, 244-246). Így tehát egyfajta „inter-penetráció” alakult ki a párt és a hadsereg között, a pártirányítás primátusának megmaradása mellett a szovjet hadsereg limitált, viszonylagos autonómiával rendelkezett számos, a rendszer számára kulcsfontosságú feladat ellátásában. Ide tartozott a szovjet kül- és geopolitikai célkitüzések megvalósítása a fejlődő országokban (szovjet katonai szakértők, tanácsadók révén), a kelet-közép-európai szovjet birodalom stabilitásának szavatolása (a Varsói Szerződés katonai szervezetén keresztül), valamint a belső társadalmi "olvasztótégely" szerepkör ellátása is (Kolkowicz 1982, 126-127). Ennek a modellnek részét képezi a pártelit és a katonai elit közötti látens konfliktus feltételezése, Kolkowicz szerint ez megjelenik az állampárt a hadsereg kontrolljára alkalmazott eszközökben is (Barany 1993, 13).

William E. Odom (1978) "intézményi egyezőség" (institutional congruence) modellje a pártelit és a katonai elit közötti "átfogó konszenzus" gondolatára épül. A szerző elveti, hogy a párt és a hadsereg közötti határok a szovjet modell esetében potenciális politikai törésvonalnak felelnek meg, valamint, hogy a hadsereg pártirányítása és a katonai hatékonyság mértéke mindig fordítottan arányos egymással. A Kolkowicz által feltételezett látens konfliktussal szemben Odom szerint, noha léteznek véleménykülönbségek a párt és a katonai vezetés között, egy "széles körü pragmatikus konszenzus" tapasztalható közöttük az államot érintő főbb 
politikai-társadalmi kérdések tekintetében. A konszenzust elősegíti, hogy a párt és a hadsereg "intézményi éthosza" alapvetően semmiben nem különbözik egymástól (Odom 1978, 27, 32-34). A szerző azon a véleményen van, hogy a szovjet hadsereg politikai szerepét inkább a bürokratikus szervezetekre vonatkozó elméletek keretei között kellene magyarázni (Odom 1978, 38-39). Alapvetően tehát a hadsereg a párt igazgatási szervének tekintendő, nem pedig egy attól politikailag különálló, azzal versengő intézménynek. Noha személyes klikkek és ezek szövetségei, mint minden bürokratikus szervezetben, a szovjet hadseregben is léteznek, Odom szerint ezek nem tekinthetők érdekcsoportnak a szó abban értelmében ahogy azt Kolkowicz használja (Odom 1978, 41-44). Ezzel szemben mind a politikai vezetés mind pedig a katonai elit érdekelt a szovjet rendszer fennmaradásában, így például a magas katonai költségvetés nem a katonai vezetésnek tett engedményként fogható fel, hanem a civil pártelit azon felismeréseként, hogy ez a szovjet állam és a szovjet "birodalom" egyben tartásának egyik szükséges eszközét alkotja (Odom 1978, 48-49). A szerző egy, a Szovjetunió felbomlása után megjelent későbbi munkájában Gorbacsov színre lépését, és biztonság- valamint katonapolitikai döntéseit is a fenti keretek között elemzi (Odom 1998, 388-404).

A Timothy Colton nevéhez füződő elképzelés alapgondolata a politikai részvétel. A szerző amellett érvel, hogy a részvétel fogalmának középpontba állítása rugalmas elemzési keretet eredményez: vizsgálható egyének, csoportok vagy az egész intézmény (a hadsereg) politikai részvétele, valamint az intézmények közötti (crossinstitutional) kapcsolatok akár egyéni akár kollektív szinten (Colton 1978, 63). A részvétel esetén vizsgálható annak terjedelme és annak eszköze: az első esetben a hadsereg belső müködésével kapcsolatos kérdésektől a rendszerszintü politikai kérdésekig terjedő skáláról beszélhetünk. A beavatkozás eszközei esetében pedig négy kategória különíthető el: a törvényileg szabályozott hatáskörök gyakorlása, tanácsadás, a politikai alkufolyamatban való részvétel, végül pedig erő alkalmazása. Így a belső katonai kérdésekben törvényileg szabályozott módon történő fellépéstől a rendszerszintü társadalmi-politikai ügyek erő alkalmazásával történő kezeléséig (katonai diktatúra) a modell a részvétel 16 különböző típusát különböztetheti meg. A brezsnyevi Szovjetunióra alkalmazva modelljét Colton arra a következtetésre jut, hogy a hadsereg politikai részvétele döntően a törvényileg elöírt hatáskörök gyakorlásán keresztül történik. 
A legtágabb, rendszerszintü ügyekkel kapcsolatos részvétel szinte kizárólag a Központi Bizottság, valamint a Politikai Bizottság katonai elithez tartozó tagjaira korlátozódik, a törvényi hatáskör gyakorlása, illetve informális tanácsadás révén (Colton 1978, 66-68). A katonaság politikai részvételének relatíve alacsony szintjére vonatkozóan a szerző azt a magyarázatot adja, hogy mivel a párt politikája nagy vonalakban megfelelt a katonai vezetés preferenciáinak, ezért annak nem áll érdekében az intenzívebb részvétel. Colton azonban nyitva hagyja azt a lehetőséget, hogy a hadsereg szándékainak változása esetén a részvétel a jövőben intenzívebbé váljon. Mindezt azzal magyarázza, hogy a párt által alkalmazott politikai ellenőrző eszközök korántsem müködnek akkora hatékonysággal, mint azt sokan feltételezik (Colton 1978, 71-72). Colton egy lényeges megállapítsa, hogy a kooptálás mindkét irányban érvényesül: nemcsak a hadseregből a pártba, hanem ellenkező irányban is. Ezzel magyarázza az írásában fontos szerepet kapott intézményközi kapcsolatok, "szövetségek" létezését.

Barany (1993, 15-17) szerint a három szerző egyike sem kínál általánosan alkalmazható magyarázatot a kommunista rendszerek civil-katonai kapcsolataira. Kolkowicz érdekcsoport-modellje túlzottan statikus, így nem tudja "követni" a civilkatonai kapcsolatok változásait a Szovjetunió történetének eltérő korszakaiban. A modell nem alkalmas például arra, hogy magyarázatot adjon a hadsereg alárendelt helyzetére a sztálini időszak alatt. Odom konszenzus-alapú elmélete nem veszi figyelembe a pártvezetés és a katonai elit közötti nézetkülönbségeket, valamint a szovjet katonai-ipari komplexum növekvő befolyását. Odom emellett nem tartja valósnak a pártelit az ún. "bonapartizmustól" való félelmét sem, noha Barany szerint a párt igenis tudatában volt annak, hogy a hadsereg a pártállam egyetlen szereplője, amely képes lenne a rendszer megdöntésére, és ezért fordított különösen nagy figyelmet a hadsereg politikai kontrolljára. Colton elmélete, noha részletesen vizsgálja a hadsereg politikai részvételének lehetséges útjait és eszközeit, nem magyarázza annak mozgatórugóit. Az alacsony szintü katonai politikai részvétel feltételezése emellett nem magyarázza a katonai vezetés (így Zsukov marsall és köre) szerepét a Sztálin halála utáni utódlási konfliktusokban, valamint a hadseregvezetés egy részének közremüködését a sikertelen 1991-es Janajev-puccsban. Barany azon az állásponton van, hogy a Kolkowicz-féle "érdekcsoport" modell leginkább a Szovjetunió létezésének utolsó, 1989-91 közötti időszakában alkalmas a hadsereg politikai szerepének magyarázatára. 
Mindemellett a három elmélet nem, vagy csak korlátozottan alkalmas a Szovjetunión kívüli kommunista államok vizsgálatára, és egyáltalán nem alkalmazható Moszkva közép-kelet-európai szatellitjeire. Barany szerint ez utóbbiak esetében a párt és a hadsereg közötti viszony inkább magyarázható az érintett államok feletti szovjet dominanciával, illetve a szovjet-orosztól gyökeresen különböző történelmi és kulturális jellemzőivel (Barany 1993, 15-17).

Perlmutter és LeoGrande (1982) szerint mind Odom, mind pedig Colton és Kolkowicz csak a párt-hadsereg viszony egy aspektusát vizsgálja, a szerzők szerint viszont a kapcsolatnak három szintje van: az ideológiai szint, a politika mikroszintje (az elitek összetétele), valamint a politika rendszerszintje (a bürokratikus szervezetek egymással való kapcsolata). Az ideológiai szinten a hadseregnek a párt alá rendelése alkotmányosan rögzített és a gyakorlatban is érvényesül. Noha a kommunista hadseregek szándékosan politikai jellegüek, igen ritka, hogy "ideológia-fejlesztő" vagy más hasonló "aktív" ideológiai szerepet játszanának. A fegyveres erők ideológiai szerepe leginkább válsághelyzetekben jelentkezhet: a szerzők szerint ennek jellemző példája a lengyel hadiállapot, ahol a lengyel állampárt teljes politikai hitelvesztése miatt - a nemzeti identitás egyik képviselőjének tekintett - lengyel hadsereg viszonylagos legitimitását kihasználva igyekeztek a rendszer túlélését biztosítani.

A politika mikroszintjén a katonai elitek a pártállam leginkább integrált elitcsoportját képezik, a kettős szerepü elitek léte és a pártirányítás primátusa mellett a hadsereg limitált intézményes autonómiát élvez. Ennek a mértéke államonként és időszakonként változik, aminek alapján a két szerző a civil-katonai kapcsolatok három típusát különíti el: a "koalíciós", a "szimbiotikus" és a "fúziós" kapcsolatot. (Perlmutter és LeoGrande 1982, 781-782)

A koalíciós civil-katonai kapcsolatok esetében a párt és a hadsereg között kölcsönös érdekeken alapuló szövetség jön létre. A két szerző szerint a Szovjetunió a késő brezsnyevi időszakban ezzel a modellel jellemezhető. A katonaság ebben az időszakban jelentősebbé vált, mint bürokratikus szervezet, de nem vált önálló politikai szereplővé. Kolkowiczal ellentétben a két szerző azt gondolja, hogy nincs fundamentális ellentmondás a professzionális hadsereg elképzelése és a politikai ellenőrzés között, valamint Kolkowicz azon megállapítását is vitatják, hogy a párt és a hadsereg közötti látens konfliktus a kapcsolat fö problémája. 
A szovjet hadsereget és annak elitjét a két szerző olyan szervezetnek látja, amely nem helyezkedik szembe a pártállam gondolatával, még ha a pártvezetés minden tagjával nem is mindig ért egyet (Perlmutter és LeoGrande 1982, 782-784).

A második, szimbiotikus típus Perlmutter és LeoGrande szerint az olyan államokra jellemző, ahol a kommunista rendszer kiépítése gerillaháború útján és azt követően történt. Jugoszlávia, és Vietnam mellett Kína e típus legfontosabb képviselője. A szimbiotikus kapcsolat a koalíciósnál jóval szorosabb kölcsönös függöséget feltételez. További különbség, hogy az összefonódás alacsonyabb szinteken is jelen van, míg a koalíciós típus esetében csak az elit szintjén érzékelhető. Kínában a kommunista párt történetének sajátos kezdeti szakasza, valamint a polgárháborús örökség miatt is alakulhatott úgy, hogy a 60-as, 70-es években a kínai hadsereg többször is politikai döntőbíró szerepet játszhatott. A pártállam intézményesülésével és az egykori gerillahadsereg állandó hadsereggé válása nyomán a viszony elmozdulhat a koalíciós típusba. Minden kommunista rendszerre, de különösen a szimbiotikus típusba sorolhatókra tartja igaznak Perlmutter és LeoGrande azt a megállapítást, hogy a relatív stabilitás periódusai a hadsereg alacsony szintű politikai jelenlétével függenek össze, míg válságok esetén a fegyveres erők jelentősebb politikai szerepet játszhatnak (Perlmutter és LeoGrande 1982, 784-785).

A harmadik, "fúziós" típust a szerzők Kubára alkalmazzák. A fúziós típus az előző, szimbiotikus kapcsolattól abban különbözik, hogy a gerillaháborús győzelem megelőzi az állampárt megalakítását, így bizonyos ideig a hadsereg az állampárt funkcióját is ellátja. Kubában csak Fidel Castro hatalomátvétele után 6 évvel, 1965ben került sor a Kubai Kommunista Párt megalakítására (pedig forradalmának marxista-leninista jellegét a kubai vezető már 1961-ben deklarálta), a párt intézményesülése pedig egészen a 70-es évek elejéig eltartott. A "klasszikus" pártállam kubai kiépülése után az ország kikerült a "fúziós" típusból, érvel Perlmutter és LeoGrande (Perlmutter és LeoGrande 1982, 785-786).

Vizsgáljuk most azt a kérdést, hogy a civil-katonai interakció milyen sajátos formái jelentkeznek a kommunista rendszerekben a két szerző szerint. Ennek alapvetően három aspektusa érdemel figyelmet: a haderő civil kontrollja, az olyan szakpolitikai kérdések, amelyekben a hadsereg érdekelve van, valamint a rendszerszintü politikaitársadalmi kérdések. A haderő civil kontrollját elsődlegesen - hasonlóképpen a nem kommunista államokhoz - az biztosítja, hogy a hadsereg elfogadja a civil vezetés felsőbbségét. 
A kommunista rendszerekben ez a párt társadalmi vezető szerepének elfogadását is jelenti. A hadsereg ideológiai kontrollja mellett annak funkcionális kontrollja is megvalósul: ennek eszközei a hadseregben jelenlévő politikai ellenőrzési, felügyeleti szervek (politikai főosztály, politikai tisztek rendszere), a nomenklatúra, a katonaság ideológiai indoktrinációja, valamint a katonai elit kooptálása a párt vezető testületeibe. Szintén ide sorolható a hadseregnek ellensúlyt képező párhuzamos eröszakszervezetek jelenléte is (Perlmutter és LeoGrande 1982, 786-788). A hadsereg limitált autonómiával és lehetőségekkel rendelkezik az őt is érintő szakpolitikai kérdésekben saját érdekei és szempontjai képviseletére, ez azonban nem jelenti azt, hogy pluralizálódás történne a kommunista rendszereken belül. A hadsereg, mint funkcionális elit kizárólag a párt csatornáin keresztül zajló alkufolyamatban képviselheti érdekeit (Perlmutter és LeoGrande 1982, 787-788).

Perlmutter és LeoGrande szerint, ami igazán megkülönbözteti a kommunista hadseregeket a nem kommunista államokban müködőktől, az a fegyveres erők rendszerszintü válságok, krízisek esetén játszott szerepe. A hadsereg átpolitizálása, politikai alárendelése, illetve a kettős szerepű elitek kialakítása a párt primátusának megőrzése érdekében történik. Ez azonban azzal a következménnyel is jár, hogy bevonja a hadsereget, illetve annak elitjét a párton belüli konfliktusokba. Ez azonban nem tekinthető a szó eredeti értelmében vett katonai beavatkozásnak: a fegyveres erők nem azzal a céllal avatkoznak a konfliktusba, hogy a párt hegemóniáját felváltsák a hadsereg hegemóniájával. hanem hogy támogassák a párt valamely vetélkedő frakcióját. Ilyen esetekben a hadsereg továbbra is a párt által irányított - a szerzők az "egyenruhás párt" kifejezést használják -, mindössze a pártegység időleges - megbomlásáról beszélhetünk. (Perlmutter és LeoGrande 1982, 787-788)

Érdemes megemlíteni, hogy William E. Odom is tulajdonképpen az "egyenruhás párt" fogalom keretei között elemzi az 1991-es szovjetunióbeli puccskísérletet, és arra hívja fel a figyelmet, hogy a történtek (a katonai vezetés egyik része a pártvezetés egy csoportjával szövetkezve kísérletet tesz a pártfőtitkár eltávolítására) lényegüket tekintve nem különböznek a korábbi hasonló epizódoktól (így például Hruscsov leváltása) (Odom 1998, 341-346).

Perlmutter (1982) szintén a pártállami civil-katonai kapcsolatok sajátos jellegére hívja fel a figyelmet. A párt és a fegyveres erők elitjének integráltságán túlmenően a kommunista rendszerekben a hadsereget a párt igazgatási és végrehajtó szervének (administrative arm) tekinthetjük. (Perlmutter 1982, 325) 
A szerző megkülönbözeti az egyszemélyi vezető irányította rendszereket (például a sztálini Szovjetunió vagy a Mao-i Kína) ahol a vezető személye jelenti az integráló eröt az egyaránt "heroikus szereppel felruházott" párt és hadsereg között. Az olyan helyzetekben, ahol nincs egyértelmű egyszemélyi vezető (például a Szovjetunió Brezsnyev idején vagy Jugoszlávia a Tito utáni korszakban) a párt és a hadsereg kapcsolata komplexebb. Perlmutter úgy érvel, hogy a hadsereg intézményesített politikai részvétele, illetve az elitek integráltsága a rendszert stabilizáló tényezőnek tekinthetö (Perlmutter 1982, 322-324).

Samuel E. Finer a Szovjetunióról írva szintén arra mutat rá, hogy a szovjet hadsereg nem tudja megkerülni vagy leváltani a pártállam intézményrendszerét, érdekeit csak a pártállami csatornákon keresztül képes érvényesíteni. A hatalomban való utódlás intézményesített rendjének hiánya miatt az utódlás rendszerint belső pártharcok eredményeképpen alakul ki. Perlmutter és LeoGrande írásához hasonlóan Finer is arra utal, hogy a katonaság szerepe és mozgástere a párton belüli válságok (frakcióharcok vagy utódlási konfliktusok) esetén nő meg. Erre jellemző példa a Sztálin halála utáni időszak, amikor Hruscsov két alkalommal is (Malenkov 1953-as és az ún. "pártellenes csoport" 1957-es eltávolítása) a katonai elit támogatásával tudott párton belüli ellenfelein felülkerekedni. (Finer 1976, 91, 95-97)

Dale E. Herspring (1999) a hidegháború után nyilvánosságra került adatokat is felhasználva szintén amellett érvelt, hogy a totalitárius modell feltételezéseit a történelmi események nem igazolták. A modell keretei között nem lehetett értelmezni a szovjetunióbeli civil-katonai kapcsolatok átalakulását, aminek következtében a viszony szorosabb jellegűvé vált. Herspring bírálta Huntington - és Kolkowicz feltételezését a párt és a katonaság közötti látens konfliktusról, arra utalva, hogy ez csak a szovjet pártállam kezdeti periódusában állt fenn. A szerző leegyszerüsítőnek tartotta azt a tézist is, hogy a pártirányítás és a katonai hatékonyság szükségképpen ellentétben áll egymással. A Szovjetunió létezésének utolsó évtizedeire a hadsereg viszonylagos autonómiát élvezetett a katonai döntéshozatalban, noha a kulcsfontosságú döntések - így például az afganisztáni hadmüvelet - meghozatalára mindig a pártban került sor (Herspring 1999, 557-558, 561-562). Ezzel párhuzamosan a pártirányítás müködése is módosulásokon ment keresztül. Herspring szerint a párt- és katonai elit szimbiotikus jellegét mutatja az is, hogy az 1990-es 28. SZKP kongresszuson keményvonalas álláspontot elfoglalók közül sokan a tiszti és fötiszti karból kerültek ki. (Herspring 1999, 567-568). 
A szerző egykori szovjet és NDK tisztek körében végzett kutatása nyomán megállapítja, hogy ezen hadseregek tisztikara "átpolitizált" volt abban az értelemben, hogy tagjai jellemzően elfogadták a fennálló rendszer legitimitását és ideológiájának alapvető téziseit. Mindez azonban nem jelenti sem azt, hogy minden esetben rendíthetetlen meggyőződéssel vallották volna a kommunista ideológiát, sem pedig azt, hogy esetenként ne kifogásolták volna a párt bizonyos intézkedéseit. A szerző szerint a huntingtoni modell alapvetően az észak-amerikai és nyugat-európai hadseregek tapasztalatai alapján született, és emiatt csak igen korlátozottan alkalmas a kommunista államok civil-katonai kapcsolatinak vizsgálatára (Herspring 1999, 569-573).

\subsection{A szatellitállamok helyzete}

Végezetül érdemes röviden megvizsgálni a kelet-közép-európai szovjet szatellitállamok helyzetét. Mint Bárány D. Zoltán megállapítja, a nyilvánvaló hasonlóságok (a hadsereg pártellenőrzése és átpolitizáltsága, párhuzamos fegyveres testületek létezése, a társadalom militarizálása) mellett alapvető különbségek is jellemzik ezt az országcsoportot a Szovjetunióhoz képest (Barany 1993, 17-18). Ezekben az államokban a kommunista rendszer kiépítésére a Szovjetunió által vagy annak közremüködésével került sor. A "korlátozott szuverenitás" volt nemzetközi kapcsolataik meghatározó eleme, a szocialista blokk modus operandi-jával szembehelyezkedő államoknak Moszkva - akár katonai - szankciójával kellett szembenézniük. A katonapolitikai és stratégiai kérdésekről nem az adott államok pártközpontjaiban, hanem Moszkvában vagy Varsói Szerződés szintjén született döntés, a katonai doktrínák és fenyegetés-percepciók is szovjet szempontok alapján kerültek meghatározásra. Szovjet minták alapján, valamint szovjet szakértők, tanácsadók közremüködésével szervezték meg a térségben magukat a kommunista hadseregeket is.

A további fő különbség Bárány szerint abban keresendő, hogy míg a szovjet rendszer végső garantálója a szovjet hadsereg volt, a kelet-közép-európai állampárti rendszerek esetében ezt a szerepet nem a saját hadseregük töltötte be. Így ezen államokban a civil-katonai kapcsolatokat leginkább a helyi hadsereg - helyi KP szovjet hadsereg - szovjet KP „négyszögben” lehet értelmezni (Barany 1993, 12, 17 19). 
Részben ezzel is magyarázható, hogy a nem szovjet VSZ tagállamok esetében a hadsereg politikai szerepe jóval alacsonyabb volt, mint akár a Szovjetunióban, akár más kommunista államokban (Kína, Jugoszlávia, Vietnam). Ez alól Lengyelország képez részleges kivételt. Itt is jellemző volt azonban a katonai és pártelit integrációja, valamint, hogy a katonai elit lojalitását privilégiumok nyújtásával kívánták megerősíteni, viszont a katonai elit magas szintü pártszervekben való jelenléte kevésbé volt kiterjedt (Barany 1993, 19-20, 147-148).

Válsághelyzetek során a katonaság lojalitása kérdéses volt, mint azt több ország és több történelmi példa is mutatja. Bárány D. Zoltán (1993, 60-65) szerint például az 1956-os magyarországi forradalom idején a katonai vezetést „zavarodottság” (1993, 65) és „bénultság” (1993, 60) jellemezte, és a hadsereg szerepe a forradalom alatt alapvetően passzív volt. Más esetekben viszont maga a politikai vezetés nem kívánta a hadsereget belbiztonsági célokra alkalmazni mivel, az említett lojalitási kétségek mellett, attól is tartottak, hogy az tovább csökkentené a hadsereg társadalmi legitimitását. A hadsereget a társadalom a legtöbb térségbeli országban a kommunista párthoz hasonlóan Moszkva képviselöjének tekintette: ez is magyarázhatta a katonaság relatíve alacsony legitimitását és társadalmi presztízsét. Lengyelország itt is részben kivételt képezett (Barany 1993, 150-153). Mindezen tényezők (továbbá a kommunista rendszer politikai kudarca, valamint a mélyülő gazdasági válság) hozzájárulhattak ahhoz, hogy egyik kelet-közép-európai államban sem tett kísérletet a katonai elit a demokratikus átalakulás megakadályozására. A katonai vezetés a legtöbb régiós országban passzív szemlélője volt a kommunista rendszerek bukásának, valamint a demokratikus rendszerváltásnak, Bulgáriában és Romániában pedig a reformkommunista erők támogatójaként lépett fel. Bulgáriában Dobri Dzsurov tábornok, honvédelmi miniszter, a Politikai Bizottság befolyásos tagjaként tevékeny részese volt a Todor Zsivkov BKP-fötitkár eltávolítására irányuló "palotaforradalomnak". Romániában az 1989. decemberi események során a katonai vezetés többsége Ceausescu ellen fordult, amely végleg megpecsételte a román diktátor és rendszere sorsát (Barany 1993, 155-157). 


\section{Civil-katonai kapcsolatok a titói Jugoszláviában (1945-1991)}

\subsection{Hadsereg és partizánháború}

A következőkben a kommunista rendszereken belüli civil-katonai kapcsolatok egy speciális példájaként a jugoszláv esetet vizsgálom meg, mely mind a Szovjetunió, mind pedig a kelet-közép-európai szovjet szatellitállamok gyakorlatától jelentősen különbözött. A jugoszláv eset vizsgálatát azért is tartom fontosnak, mert a jugoszláv "történelmi örökség" az esettanulmányok tárgyát képező két ország civil-katonai kapcsolataira is hatást gyakorolt, különösen függetlenségük kezdeti időszakában. E fejezetben a szlovéniai és horvátországi eseményeket csak röviden szerepeltetem, azok bővebb tárgyalása az adott országot érintő esettanulmányban található.

Jugoszlávia 1945 és 1991 közötti területi beosztását a 2. ábra illusztrálja.

\section{2. ábra: Jugoszlávia területi beosztása 1945 és 1991 között}

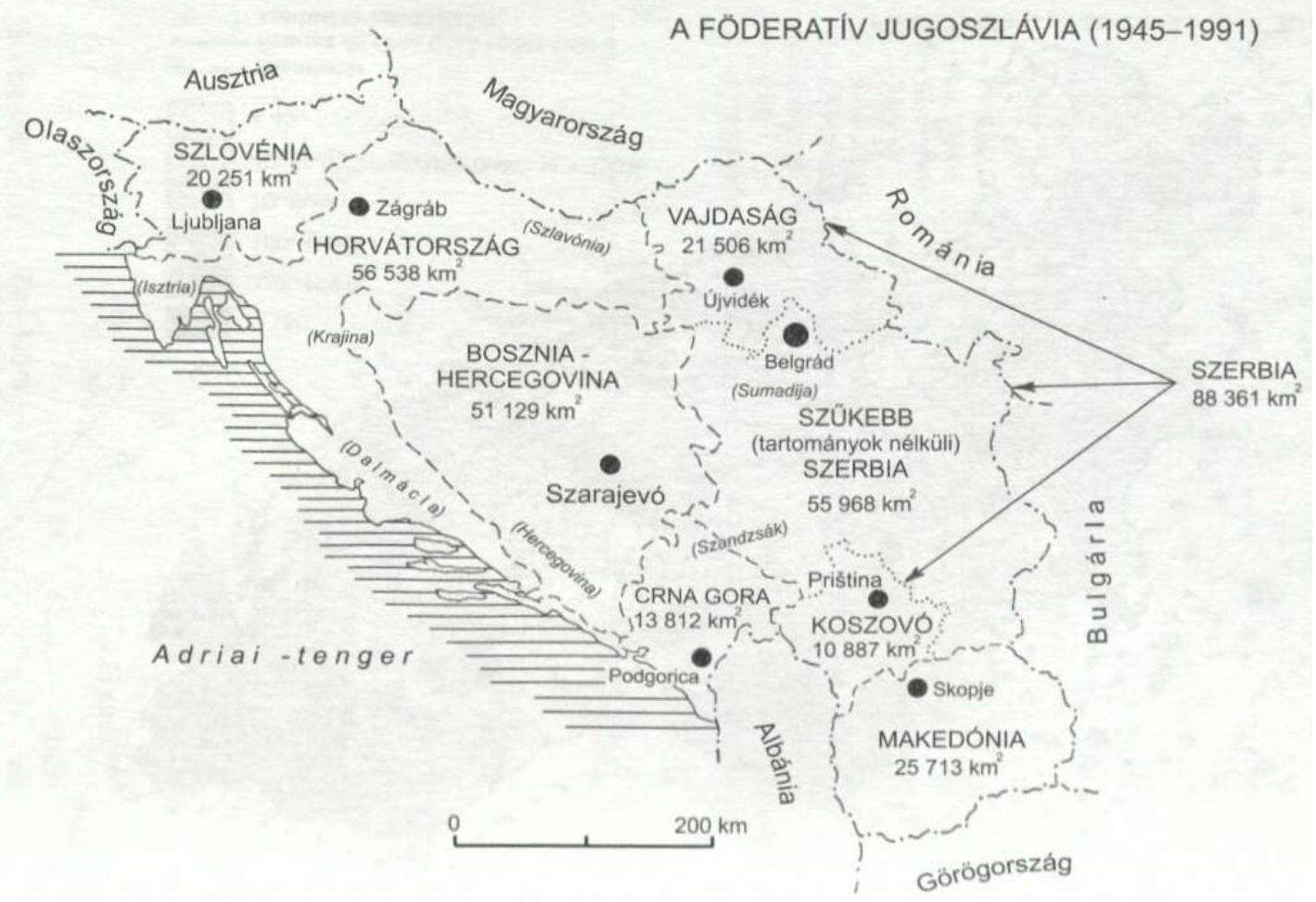

Forrás: Juhász József: Volt egyszer egy Jugoszlávia. AULA: Budapest, 372. old. 
E helyütt nincs mód a fegyveres erők jugoszláviai, illetve szerbiai politikaitársadalmi szerepét történelmi perspektívában vizsgálni, ugyanakkor mindenképp megjegyzendő, hogy a hadsereg a kommunista időszakot megelőzően is több esetben kulcsszerepet játszott (a királyi) Jugoszlávia, illetve Szerbia politikai életében. Ennek illusztrálására elegendő két példát említeni: 1903-ban a tisztikar közremüködésével került sor arra a "palotaforradalomra" melynek során a hatalmon lévő Obrenović dinasztia uralkodóját, I. Sándort meggyilkolták és a Karađorđević-család egyik tagja került az ország trónjára (Finer 1962, 55-56). Hasonlóképpen, 1941 márciusában a légierő egyik tábornoka, Dušan Simović vezette puccs távolította el hivatalából Dragiša Cvetković miniszterelnök kormányát, mert az aláírta Jugoszlávia csatlakozását a tengelyhatalmak által alkotott háromhatalmi egyezményhez. Ez az államcsíny néhány nappal később végül az ország német megszállásához vezetett (Gow 1992, 6). Ezzel ellentétben a mai Szlovénia és Horvátország 1918-ig a Habsburg birodalom, majd az Osztrák-Magyar Monarchia részeként a civil-katonai kapcsolatok terén is eltérö történelmi tapasztalatokkal rendelkezett: itt a fegyveres erők politikai beavatkozására egyáltalán nem volt példa. (Bővebben lásd Juhász 1999, 5-20, és Remington 1978, 251-253)

A titói Jugoszlávia civil-katonai kapcsolatai nem érthetőek meg a rendszer partizánháborús eredete nélkül sem. A gerilla- vagy partizántevékenység ugyanakkor nem a második világháború során jelent meg a térségben, ennek a balkáni régióban komoly történelmi hagyományai vannak. A Tito vezette partizánokkal rivalizáló konzervatív-nacionalista ellenállási mozgalom, a csetnikek elnevezése éppenséggel a törökök ellen harcoló szabadcsapatokat is jelölő "četa" szóból származik (Roberts 1987, 20). A partizántevékenység Jugoszlávia területén 1941 nyarától bontakozott ki és a konfliktus során a "regularizálódás" irányába haladó Tito vezette katonai erők melyek 1942-től felvették a Népi Felszabadító Hadsereg elnevezést, a fővárost, Belgrádot kivéve önállóan szabadították fel az országot a tengelyhatalmak uralma alól (Sudetic 1992, 42). Az ellenállás döntően "hazai" jellege, és a szovjet hadsereg minimális jugoszláviai szerepe - Moszkva nem is állomásoztatott haderőt Jugoszláviában 1945-ben - nem csak szimbolikus okokból, és legitimációs bázisként volt fontos a rendszer számára, hanem konkrét politikai jelentőséggel is bírt az 1948as Tito-Sztálin szakítás alkalmával (Gow 1992, 39). Tito - taktikai okokból - a konfliktus kezdeti szakaszában inkább a partizánmozgalom felszabadító, mintsem kommunista jellegét hangsúlyozta: a Népi Felszabadító Háború, mint ahogy a 
későbbi hivatalos történetírás nevezte ezt a konfliktust, egyszerre tüzte ki célul a tengelyhatalmak kiüzését az országból, illetve a Jugoszláviát alkotó nemzetiségek közötti egyenlőség ígéretét (Roberts 1986, 130-131). Ez utóbbit fejezte ki később a rendszer retorikájában a "testvériség-egység" (bratsvo i jedintsvo) doktrínája (Gow 1992, 22). De, mint Remington is megjegyzi, nem téveszthetjük szem elől azt sem, hogy az országban a megszállók elleni harccal párhuzamosan polgárháború is zajlott. A horvátországi, illetve boszniai szerbség például a tengelybarát horvát usztasák népirtó tevékenysége hatására is csatlakozott jelentős számban a partizánmozgalomhoz. (Remington 1997, 63-64) A partizánmozgalom pedig, noha kétségtelenül multietnikus mozgalom volt, soraiban a horvátok és szlovének alulreprezentáltak, a szerbek és montenegróiak pedig felülreprezentáltak voltak (Gow 1992, 34-35). Ez a tendencia, mint látni fogjuk, a későbbi Jugoszláv Néphadseregre is jellemző volt. A partizánháborús időszakban a párt és a hadsereg kapcsolatát a fúzió jellemezte, nemcsak a legfelsőbb politikai és katonai vezető szerepét töltötte be Tito egy személyben, hanem a Népi Felszabadító Hadsereg parancsnoksága, illetve a Jugoszláv Kommunista Párt PB-jének személyi összetétele is megegyezett. Mint Gow rámutat, a hadsereg, pontosabban a sikeres partizánharc legitimálta a Jugoszláv Kommunista Pártot, mint politikai szereplőt, majd később pedig a JKP legitimálta a hadsereg politikai szerepét (Gow 1992, 29-32). Mindez pedig azt is jelentette, hogy a pártvezetésen belül évtizedeken át az ún. "1941-es kör", azaz a párthoz a partizánharc elején vagy azt megelőzően csatlakozott, és háborús tapasztalatokkal is bíró vezetők, élveztek kiemelt szerepet. A katonai elitben a partizánmúlt sokkal tovább játszott meghatározó szerepet, mint a "civil" párt és állami vezetésben. Érdemes megemlíteni, hogy a partizánháború résztvevői körült került ki a párt tagságának nagy része is a kezdeti időszakban: az ún. "első harcosok" (prvoborci), azaz a partizánmozgalomban annak kezdetétől részt vevő veteránok egészen a hatvanas évekig a háború utáni politikai és társadalmi élet alsóbb szintjein is preferált elbánásban részesültek, hasonlóképpen a pártelitben az "1941-es kör" által játszott vezető szerephez (Remington 1997, 63).

Jugoszlávia 1945 utáni története, némi leegyszerüsítéssel egymást követő centralizációs és decentralizációs hullámokként írható le. Lényeges ugyanakkor megjegyezni, hogy a decentralizáció a hadsereget csak igen kis mértékben érintette, annak képviselői pedig amikor lehetőségük volt erre, a centralizáció és az összállami egység mellett szálltak síkra (Cohen 1995, 27). Elemzési szempontból az 1945 és 
1991 közötti időszakot 5 periódusra bontottam: az 1941/1945 és a 60-as évek eleje közötti, a hatvanas évekbeli, az 1971-es válságtól Tito haláláig (1980) terjedő, valamint a Tito utáni éra első 7 évét felölelő (1980-1987) periódust különítettem el. Végezetül pedig bővebben tárgyalom a jugoszláv állam létezésének utolsó időszakát, melynek kezdete Juhász (1999, 190-191) és saját álláspontom szerint is Milosevics színre lépésével (1986-87) datálható.

\subsection{A Jugoszláv Néphadsereg és a jugoszláv rendszer eredete (1945-1961)}

A második világháború utáni években mind az államot, mind pedig a hadsereget szovjet minta alapján szervezték át: az alapvetően regionális alapú, az adott régióból származó tisztek által irányított és az adott etnikum által használt vezényleti nyelvű hadsereget centralizált, központilag irányított és szerbhorvát ${ }^{6}$ vezényleti nyelvü haderővé alakították, ekkor még Jugoszláv Hadsereg elnevezés alatt. ${ }^{7}$ Szovjet csapatok nem állomásoztak Jugoszlávia területén de az 1945-48 közötti időszakban felszerelés és fegyverzet terén az ország erősen függött a Szovjetuniótól. A hadseregben jelentős szerepet játszottak a szovjet katonai tanácsadók, melyek tevékenysége, néhány évvel később az egyik okát képezte a Tito-Sztálin szakításnak. A fegyveres erőkben a pártirányítás szovjet típusú intézményes struktúráit alakították ki: a Politikai Főosztály mellett megtartották a partizánháborús időszakban létrejött komisszár-rendszert is, emellett a legénységi és tiszti állomány "politikai megbízhatóságát" a politikai rendőrség kiterjedt jelenléte révén is kívánták biztosítani. Ez utóbbi kezdetben a Népvédelmi Osztály (OZN), majd az Állambiztonsági Hivatal (UDBA) elnevezést viselte, és a szovjet KGB-hez, valamint elődszervezeteihez hasonlóan a kommunista párt irányítása alatt állt (Johnson 1982, 183, Milivojevic 1992, 204-207). Jelen fejezetben terjedelmi okok miatt nincs mód a Tito-Sztálin szakítás előzményeivel és lefolyásával részletesen foglalkozni. Mindenképp megjegyzendő azonban, hogy a szakítás okai között több katonai, katonapolitikai kérdés is szerepelt. Roberts (1986, 143-145) szerint ezen katonai és katonapolitikai nézetkülönbségek alapvetően három fő területre terjedtek ki.

\footnotetext{
${ }^{6}$ A szerbhorvát a hadsereg hivatalos vezényleti nyelve volt a rendszer fennállása alatt, ugyanakkor az egyes tagköztársaságok nyelvei -köztársasági szinten- hivatalos státuszt élveztek. A hadseregen kívül szövetségi szinten azonban egyetlen nyelv sem volt hivatalos nyelvként megjelölve. Lásd Blum 2002, 41-42, 69-80.

${ }^{7}$ A haderő már a Tito-Sztálin szakítást követően, 1951-ben kapta az 1992-ig használt Jugoszláv Néphadsereg [JNH] elnevezést.
} 
A Szovjetunióból történő fegyverszállítások kapcsán Jugoszlávia sérelmezte, hogy a szovjetek leginkább elavult vagy rossz minőségü fegyvereket és hadianyagot szállítottak, mégpedig aránytalanul magas árakon. A jugoszláv katonai és politikai vezetés a hadsereg háború utáni felépítését illetően egy Moszkvától katonailag független és doktrínáiban részben a második világháborús tapasztalatokat is felhasználó haderőt képzelt el. Ezzel szemben Moszkva a Jugoszláv Hadsereg szovjet mintára és szovjet irányítás alatti átszervezését szorgalmazta. A harmadik vitapont ennek kapcsán a Jugoszláviába küldött szovjet katonai tanácsadók szerepére irányult: Belgrád túl szélesnek tartotta jogköreiket és hogy számos esetben nem tanácsadó, hanem "irányító" szerepet játszanak (Roberts 1986, 143-145). Több szerző azon az állásponton van, hogy a rendszer a partizánháborús győzelem által teremtett belső legitimitása mellett az állambiztonsági apparátus és a hadseregvezetés Tito-hoz való lojalitása is kulcsszerepet játszott abban, hogy Jugoszlávia eredményesen tudott szembe fordulni Moszkvával (Roberts 1986, 151, Remington 1978b, 183-184). A szovjet fenyegetés a 40-es évek végén, az 50-es évek elején "mesterséges nemzeti egységet" (Remington 1978b, 186 és Remington 1997, 62-63) teremtett, emellett a katonai kiadások, illetve a hadsereg létszámának drasztikus növeléséhez is vezetett. Remington szerint a hadsereg ideológiai és funkcionális identitását a szakítás inkább megerősítette, szemben a párttal, melynek új ideológiai vezérelvre volt szüksége a sztálinizmussal való szembefordulást követően. Ezt a Jugoszláv Kommunista Párt (1952-től Jugoszláv Kommunisták Szövetsége, JKSZ) az először a 6 . pártkongresszuson meghirdetett "önigazgató szocializmus" doktrínájában vélte megtalálni. (Remington 1978, 256-258) Eme önigazgató szocialista modell kialakulása a hadsereg pártirányítására is hatással volt: 1949-ben leépítették, majd 1953-ban teljesen megszüntették a komisszár-rendszert, a Politikai Főosztályt jelentősen csökkentett hatáskörökkel szervezték újjá, a hadsereg pártszervezetének vezető tisztségeit pedig a tisztikar tagjaival töltötték fel. Mindez tovább növelte a hadsereg politikai autonómiáját. A Jugoszláv Néphadsereg legitimációs szerepe mellett tehát, - különösen a 60-as évek elejéig - privilegizált gazdasági pozíciót élvezett a jugoszláv rendszeren belül, azonban ez nem fordítódott le a tisztikar vagy a katonai vezetés aktív politikai szerepére vagy akárcsak "láthatóságára". Ezzel egy időben a hadsereg és a társadalom egymástól relatíve elszigetelt volt, a kettő közötti fó érintkezési pontot a sorkatonaság rendszere jelentette. (Johnson 1982, 184-187) 


\subsection{Professzionalizáció és érdekcsoport-politika (1961-1971)}

A hatvanas évekre tehető a jugoszláv rendszer történetének legátfogóbb reformsorozata is, mely a gazdaságpolitika, a politikai rendszer mellett a fegyveres erőkre is kiterjedt. A jugoszláv gazdaságirányítási rendszer átalakítása az 1961-es és 1965-ös reformcsomagok nyomán megnövelte a tagköztársaságok gazdasági önállóságát és ezáltal jobban felszínre kerültek a jugoszláv föderáció egyes alkotóelemei közötti gazdasági fejlettségbeli különbségek. A gazdaságilag fejlettebb tagköztársaságok a decentralizáció továbbvitelét, míg a kevésbé fejlettek a föderáción belüli gazdasági újraelosztás fenntartását szorgalmazták. A tagköztársasági hatáskörök komolyabb erösítését, valamint a gazdaságban a piaci mechanizmusok erősítését ellenző csoport egyik vezéralakja Aleksandar Ranković, az állambiztonság (UDBA) nagy hatalmú vezetője volt (Juhász 1999, 140-141). Mivel a hatvanas évek elején javult a jugoszláv-szovjet viszony is, a JNH-elitnek tehát ebben az időszakban azzal a lehetőséggel kellett szembenéznie, hogy az általuk irányított intézmény a korábbi gazdaságilag privilegizált helyzet után a korlátozott gazdasági erőforrásokért versengő egyik érdekcsoporttá válik (Remington 1978b, 185-186, Johnson 1982, 184-185).

A "keményvonalas" és "reformer" erők közötti szembenállásban igen fontos fordulópont volt Ranković 1966 júliusi eltávolítása. Ironikus módon a második világháborús múlttal is bíró Ranković, aki ugyanezen évig a Veteránszövetség elnöki tisztségét is betöltötte, a katonapolitika területén ellenezte a haderő decentralizálását és az irreguláris vagy "partizán" hadviselés elemeinek a védelmi rendszerbe való beépítését (ld. pl. Roberts 1986, 157). Eltávolítása ugyanakkor a politikai közélet liberalizálódásához is hozzájárult: a Szövetségi Parlament 1966 decemberi ülésén első alkalommal folytattak vitát a katonai költségvetésről, ahol a védelmi szféra területén történő kiadáscsökkentés eddig tabunak számító kérdésköre is terítékre került (Roberts 1986, 157-158). A Ranković-ügy az állambiztonság soraiban is nagyarányú tisztogatásokhoz vezetett, magát az intézményt pedig radikálisan átszervezték (Juhász 1999, 144). Az állambiztonsági szolgálat decentralizálásával együtt pedig a katonai hírszerzés (KOS) jutott annak irányításában meghatározó szerephez. Mindezt az is jól mutatta, hogy az UDBA- utódszervezet SDB (Állambiztonsági Szolgálat) első vezetője, Ivan Mišković, a JNH vezérezredese a KOS éléről érkezett a szervezethez. 
A "civil" állambiztonság ettől számítható hadsereg általi irányítása és felügyelete, mely a jugoszláv rendszer megszünéséig fennmaradt, a kommunista világban példa nélküli jelenség volt (Juhász 1999, 144, Milivojevic 1992, 211-213). Az 1966-os eseményeket követően a párt csúcsvezetése a hadsereget illetően meghirdette a "nyitás a társadalom felé" politikáját. Ez az elképzelés arra irányult, hogy oldja a fegyveres erők "társadalmi izolációját" és megakadályozza, hogy a hadsereg a jövőben bármikor a folyamatban lévő társadalmi reformokat elszabotálni vagy megállítani kívánó társadalmi-politikai erővé válhasson. Ennek keretében a JNHvezetés célként hirdette meg a tisztikar etnikailag reprezentatívabbá tételét (Johnson 1982, 187-188). A Szovjetunió 1968 augusztusi csehszlovákiai beavatkozása újjáélesztette a szovjet biztonsági fenyegetést, melynek következtében - felgyorsítva a néhány éve már folyamatban lévő ez irányú előkészületeket - a jugoszláv vezetés egy új típusú védelmi rendszer és doktrína bevezetéséről döntött (Johnson 1982, 184185, Roberts 1986, 161-164). Az ún. össznépi védelem (szerbül és horvátul opstenarodna odbrana, szlovénul vseljudska obramba vagy splošna ljudska obramba) rendszerében a Jugoszláv Néphadsereg mellett minden tagköztársaságban létrehozták a Területvédelmi Erőket (TO). A területvédelem maga is többszintű volt, reguláris jellegü, könnyüpáncélos képességekkel is felszerelt köztársasági szintű és helyi, milícia-típusú egységek alkották. A területvédelem finanszírozása részben tagköztársasági szinten történt, és a rendszer eredeti változatában parancsnokságuk kívül esett a JNH parancsnoki láncán és békeidőben a tagköztársasági és tartományi vezetésnek tartozott felelösséggel (Johnson 1982, 185). A rendszer fő célja az volt, hogy egy túlerőben lévő ellenfél támadása esetén a reguláris haderő alkalmazása, a gerillaharc és a szervezett civil (állampolgári) ellenállás kombinációja útján az ellenfél számára vállalhatatlanul magassá tegyék az ország megszállásának katonai, politikai és gazdasági "költségét" (Johnson 1971).

Az akkori svájci modelltől eltérően a Területvédelem és a JNH az össznépi védelem rendszerében "mellérendelt" szerepet játszott. Korlátozott támadás esetén a hadseregnek képesnek kellett lennie önállóan visszaverni azt, az ország elleni átfogó invázió esetén pedig lelassítani az ellenfél elörenyomulását annyira, hogy az általános ellenállás megszervezésére elegendő idő álljon rendelkezésre. Hivatalosan az országnak "bármelyik irányból" érkező fenyegetésekre fel kellett készülnie, a gyakorlatban 1968 után a katonai tervezők a támadást elsődlegesen a Szovjetuniótól várták. 
A fentebb említett "átfogó invázió" forgatókönyvében például egy páncélos és légi szállítású erők tömeges bevetésével végrehajtott meglepetésszerü támadást feltételeztek, amely a Szovjetunió vonatkozó képességeit és doktrínáját tükrözte (Johnson 1982, 185-186). Jelen fejezetben terjedelmi okok miatt nincs lehetőség az össznépi védelem doktrína kialakulásának és bevezetése körülményeinek részletes vizsgálatára (bővebben lásd Johnson 1971 és Roberts 1986, 156-171). Mindenképpen megjegyzendő azonban, hogy bevezetése mögött több, egymástól különböző érdek vagy megfontolás is megtalálható volt. Szerepet játszott a partizánháborús örökség, a modern hadviselés azon jellemzője, hogy a front és a hátország esetenként "összemosódik", az akkor zajló vietnami háború egyes tapasztalatai, valamint annak felismerése, hogy a 60-as évek végén Jugoszláviában gazdasági és politikai okok miatt nem lenne megvalósítható a negyvenes-ötvenes évek nagyszabású újrafegyverkezése az újjáéledő szovjet fenyegetésre válaszul (Roberts 1986, 159160, Johnson 1971, 2-3). Az össznépi védelem doktrínájának volt egy, az 1971-es horvátországi események (lásd alább) után eltűnő vagy háttérbe szoruló aspektusa is. Néhány köztársaság, közöttük elsődlegesen a horvátok az össznépi védelem rendszerében a haderő decentralizálásának és ezáltal a szerb katonaierőszakszervezeti dominancia korlátozásának eszközét látták. Így tehát számukra az össznépi védelem és a tagköztársaságok erőteljesebb szuverenitásának gondolata összekapcsolódott. Savka Dabčević-Kučar, a Horvát Kommunista Szövetség 1971ben eltávolított elnöke volt ennek az értelmezésnek a legfontosabb képviselője (Roberts 1986, 157-158). Az érintett tagköztársaságok a JNH-t illetően például azt kívánták elérni, hogy a sorkatonák a saját köztársaságukban tölthessék a katonai szolgálatukat, valamint, hogy az illető egységek vezényleti nyelv az adott köztársaság nyelve legyen és ne a szerbhorvát (Dean 1982, 87).

Az össznépi védelem doktrína meghirdetése és a Területvédelmi Erők felállítása azt is jelentette, hogy a JNH egy "funkcionális riválist" kapott. Noha a katonai vezetés elfogadta az új doktrínát, az 1969 és 1990 közötti időszakban - a színfalak mögötti lobbizás, vagy az erre irányuló civil szándékok támogatása útján - arra törekedett, hogy visszaállítsa a JNH domináns vagy "monopol" helyzetét a honvédelem területén. (Remington 1997, 65-66, 72-73)

Mint fentebb említettem, a 60-as évek második felében, a korlátozott politikai liberalizáció körülményei között felélénkült a jugoszláviai közélet, ennek keretében a köztársasági partikularizmusok, valamint a nemzeti törekvések is szabadabb teret 
kaptak. Horvátország és kisebb mértékben Szlovénia már korábban is sérelmezte a Jugoszlávián belüli gazdasági újraelosztás mértékét, ezért a hatvanas évek decentralizáló reformjainak fö szorgalmazói közé tartoztak. A további gazdasági reformokra vonatkozó horvát törekvések elsősorban a devizabevétel feletti tagköztársasági rendelkezésre irányultak, a gazdasági igények azonban összekapcsolódtak bizonyos nemzeti-nemzetiségi törekvésekkel, így például a horvát nyelv helyzetével is (Juhász 1999, 150-152). A „horvát tavasz” nevet viselő reformmozgalom azonban 1971 közepére-végére túllépett a horvát KSZ keretein és egyes értelmiségi, valamint diákcsoportok kifejezetten radikális követeléseket (például önálló horvát haderő, vagy a Szovjetunión belül Ukrajna és Belorusszia példájához hasonlóan önálló horvát ENSZ-tagság) fogalmaztak meg (Juhász 1999, 151-152). Ezek a radikális követelések már elfogadhatatlanok voltak Tito számára is és a jugoszláv államfő a "horvát tavasz" mozgalommal szembeni fellépésre szánta el magát. A bekövetkező "konzervatív ${ }^{8}$ fordulat" vagy recentralizációs hullám a hadsereg társadalmi szerepét is jelentősen érintette (Milivojevic 1988, 21-22, Juhász 1999, 152-156).

\subsection{Az 1971-es válság és a hadsereg "politikai intézményesítése" (1971-1980)}

A "horvát tavasz" elleni fellépés kezdetét a szakirodalom a JKSZ szövetségi elnökségének 1971. december eleji üléséhez köti, ahol az akkor zajló horvátországi diáksztrájkokat "ellenforradalminak" minősítették, és elítélték a horvát KSZ-ben zajló "nemkívánatos folyamatokat". Tito ebben az időszakban elmondott több beszédében utalt arra is, hogy a hadsereg feladatai közé tartozik "a forradalom vívmányainak védelme" az ország határain belül is (Roberts 1986, 132-134, Juhász 1999, 151-152). 1971 decemberében és 1972-ben nagyszabású személycserékre került sor a Horvát Kommunista Szövetség vezetésében és a "normalizációs" politika kiterjedt a horvátországi értelmiségre, a felsőoktatási intézményekre és más társadalmi szervezetekre is ahol több ezer, a "horvát tavasz" mozgalomhoz köthető ember veszítette el pozícióját (Juhász 1999, 152-153). Noha az 1971-72-es politikai tisztogatások többségében Horvátországban zajlottak, a történtek nem szükíthetők le egy ideológiai köntösbe öltöztetett etnikai szembenállásra.

\footnotetext{
${ }^{8}$ A "konzervatív" szót itt a "keményvonalas" vagy "ortodox kommunista" értelemben használom.
} 
Mindez alátámasztható azzal a ténnyel is, hogy 1972-ben a személycserék kiterjedtek a technokrata-modernizációs "menedzserszocializmus" irányvonalát képviselő, Marko Nikezić által fémjelzett szerbiai párt- és állami vezetésre is (Juhász 1999, 154-155). Kérdéses, hogy az ekkor zajló eseményekben milyen szerepe volt a JNH vezetésének, különösen annak fényében, hogy ekkoriban számos küszöbön álló katonai puccsról szóló hír jelent meg a jugoszláv sajtóban. Több szerző azon az állásponton van, hogy nem felel meg a valóságnak az az értelmezés, amely szerint Tito a hadseregvezetés fenyegetése vagy zsarolása nyomán szánta el magát a "rendteremtésére". A katonai elit azonban kétségtelenül a válság kezdetétől egyértelmüen, nyilvánosan is állást foglalt a "horvát tavasz" mozgalom ellen. Ezen felül a tábornokok Titot is többször próbálták a "kemény fellépés" szükségességéröl meggyőzni és az általuk szolgáltatott, a horvát mozgalom radikális jellegét bizonyító információk minden bizonnyal szerepet játszottak abban, hogy a jugoszláv államfő cselekvésre szánta el magát (Remington 1978b, 190-193, Remington 1985, 57-58, Remington 1997, 65-66, Roberts 1986, 132-134).

James Gow (1992, 24-25) arra hívja fel a figyelmet, hogy a hadsereg társadalmi legitimitására is szükség volt ahhoz, hogy Tito sikerrel hajthassa végre a végső soron a jugoszláv állam felbomlásával is fenyegető horvát szuverenitási mozgalom elleni fellépést. A marsall egyik közeli munkatársa és "jobbkeze", Vladimir Bakarić ugyanakkor a válság tetőpontján egy német lapnak adott interjújában annak adott hangot, hogy a hadsereg politikai beavatkozása komoly veszélyeket is jelent, illetve, hogy az esetleges katonai hatalomátvétel akár polgárháborúhoz is vezethet. Ez azt jelzi, hogy a jugoszláv politikai csúcsvezetés legalább annyira tekintette a hadsereg politikai szerepvállalását lehetőségnek, mint fenyegetésnek (Milivojevic 1988, 22). Az 1971-es válság és az azt követő "normalizáció" kapcsán mindenképp szólnom kell a veteránok politikai szerepéről. A Veteránszövetség (hivatalos nevén a Népi Felszabadító Háború Veteránjainak Szövetsége) szövetségi és tagköztársasági szervezetei a válságot megelőzően és azt követően is következetesen ortodox kommunista álláspontot képviseltek, bírálva a horvát nemzeti mozgalmat, a "liberálisnak" tartott szerbiai pártvezetést, továbbá általánosságban a decentralizációs trendeket. Álláspontjuk azonban nem csupán ideológiai meggyőződésből fakadt. A veteránok 1945-től a 60-as évek közepéig a társadalom privilegizált csoportját képezték, azonban életkoruk vagy képzettségük elégtelen volta miatt a megváltozott körülmények között az állami-politikai vagy a gazdasági élet partvonalára szorultak, 
Ranković 1966-os eltávolítását követően pedig mint láttuk politikai "kijáró" és lobbipotenciáljuk is jelentősen csökkent. Mindezek miatt tehát a veteránokat az elveszett státusz és privilégiumok visszaszerzésének igénye is motiválhatta (Dean 1982, 90-91). Horvátországban mindemellett etnikai motivációk is szerepet játszhattak a veteránok álláspontjában, mivel történelmi okok miatt az itteni veteránok túlnyomó többsége a szerb etnikumból került ki (Remington 1978b, 189191). A veteránok a horvátországi politikai tisztogatásokat követően is az ortodox politikai pólust képviselték, egyebek mellett olyan általuk nem kívánatosnak tartott jelenségek ellen is felemelve hangjukat, mint a növekvő társadalmi rétegződés vagy a "deviáns mủvészeti irányzatok". Tito és a párt csúcsvezetése ambivalens álláspontot foglalt el a veteránokkal kapcsolatban: több esetben támaszkodtak a veteránok által megtestesített politikai csoportra, de ugyanakkor időről időre bírálták is "túlbuzgóságukat" (Dean 1982, 90-91). Lényeges ugyanakkor megjegyezni, hogy a veteránszövetség nem tekinthetö a JNH vagy a katonai elit "meghosszabbított karjának" hanem tagságának összetétele miatt saját jogon vett részt az ekkor zajló politikai vitákban (Johnson 1982, 190).

Azt a tényt, hogy a hadsereg pártszervezete sem volt mentes a Tito és munkatársai által "nemkívánatosnak" tartott eszméktől, a tagsági adatok is igazolják: 1971 októberében a nagy személycserék kezdete előtt a hadsereg KSZ-szervezete 80 ezer tagot számlált, mely néhány hónap alatt 66,500 före csökkent (Dean 1982, 92). Szintén megemlítendő a horvát származású Janko Bobetko tábornok esete, aki többször kiállt a hadsereg "önigazgató társadalomba való integrálása" és decentralizálása mellett, és akit a "horvát tavasz" mozgalom bukását követően eltávolítottak pozíciójából (Remington 1985, 71-72). Bobetko később, 1992-től a független Horvátország haderejének vezérkari fönöke lett. A "horvát tavasz" bukásának egyik következménye volt, hogy megkezdődött a Területvédelmi Erőknek a JNH parancsnoki szervezetébe való "betagolása": az 1974. évi honvédelmi törvény a JNH-t egy "egységes védelmi rendszer" fö elemeként határozta meg, és korlátozta a tagköztársaságok jogosítványait a területvédelem terén (Roberts 1986, 179-180). Dean szerint azonban nem lehet a területvédelmi erőket "centralizáló" változtatásokat úgy értelmezni, hogy azokat a hadsereg kényszerítette vagy "járta ki" magának. Ezek az intézkedések a "horvát tavasz" válság utáni recentralizációs hullám termékei voltak, és mint ilyen a párt-csúcsvezetés - és Tito - nevéhez voltak köthetőek, noha kétségtelen, hogy a hadsereg érdekeit is szolgálták (Dean 1982, 88). 
Az 1970-es évek elején a hadsereg JKSZ-szervezetét is átszervezték: 1974-től azt "önállósították", azaz közvetlenül a szövetségi párt alá rendelték, hasonlóan a tagköztársasági és tartományi JKSZ-"tagpártokhoz". Ily módon a párton belüli politikaformálás folyamatában a "hadsereg-párt" a tagköztársasági és tartományi "pártokkal" egyenlő szerephez jutott, amelyet az is mutatott, hogy a Központi Bizottságon belül a JNH pártszervezet azonos taglétszámmal (15) képviseltette magát, mint Koszovó és a Vajdaság autonóm tartományok (Dean 1982, 86, 92, Johnson 1982, 190-191).

Az évtized közepére tehető az ún. "politikai tábornokok" színre lépése is, azaz az a gyakorlat, hogy egyes, a honvédelemhez szorosan nem köthető állami vagy társadalmi vezető pozíciókat a JNH aktív vagy nyugalmazott állományú főtisztjei töltöttek be. A hetvenes évek második felében több-kevesebb ideig JNH-tábornok töltötte be a legföbb ügyész, a polgári légügyi hivatal vezetője, valamint a JAT állami légitársaság elnök-vezérigazgatói posztját. Anton Bebler adatai szerint ugyanebben az időszakban JNH-tisztek álltak olyan szervezetek élén is mint a Jugoszláv Autóklub vagy a Jugoszláv Sportrepülö Szövetség (Bebler 1993, 125).

A politikailag legjelentősebb azonban Franjo Herljević vezérezredes szövetségi belügyminiszterré való kinevezése volt, így 1974 és 1982 között, Herljević hivatali ideje alatt a JNH jelentős befolyást gyakorolhatott az Állambiztonsági Szolgálat (SDB) mellett a rendőrség, a határőrség, valamint a munkásőrség (munkásmilícia) felett is (Milivojevic 1988, 22).

A katonai elit tagjai jelentős számban képviseltették magukat olyan (bel)biztonsági tanácsadó és döntés-előkészítő testületekben is, mint a Honvédelmi Tanács vagy az Alkotmányos Rend Védelmének Tanácsa. Lényeges ugyanakkor megjegyezni, hogy Tito életében ő mondta ki a végső szót a stratégiai fontosságú kérdésekben, különösen a katonai és belbiztonsági szférán belül. A "politikai tábornokok" jelenléte a szüken vett katonai szférán kívül azonban nem vált trenddé, a fent említett vezetőket távozásukat követően általában civilek váltották. A katonai vezetés számára a politikai részvétel fő csatornája továbbra is a JKSZ maradt (Johnson 1982, 190-191, Remington 1985, 57-62, Milivojevic 1988, 20-25).

A hetvenes évek közepére tehát - a hadsereg legitimáló funkcióját is felhasználva sikerült az államot konszolidálni, mindez azonban a politikai demokratizációs folyamatok visszafordításával, a pártállam megszilárdításával vagy restaurációjával járt együtt. 
Noha az 1974-ben elfogadott alkotmány a korábbi horvát, szlovén és macedón nemzeti-tagköztársasági törekvések nagyobb részét teljesítette, pusztán a „decentralizált pártállam” intézményrendszerét teremtette meg. Mindez pedig könnyen lehetséges, hogy a demokratikus föderációvá alakulás (és így a jugoszláv állam hosszú távú fennmaradása) utolsó valós esélyének elszalasztását is jelentette. A tagköztársasági, és ezen keresztül részben az etnikai érdekek képviseletének a „decentralizált pártállam” keretei között történő legitimálása ugyanis később oda vezetett, hogy magával a pártállammal szembeni kritikák is „nemzeti köntösben” fogalmazódtak meg, mely a politikai konfliktusokat a köztársaságközi viták síkjára terelte, így aláásva az állam és a társadalom stabilitását (Juhász 1999, 155-156).

A JNH pártszervezete Tito halálakor a Jugoszláv Kommunista Szövetség legerősebb belső kohézióval bíró része volt, a katonai elit pedig egyenrangú részese annak a civil-katonai koalíciónak, amely az államfö halála után volt hivatott Jugoszlávia kormányzására. Összegzésképpen tehát azt állapíthatjuk meg, hogy a vizsgált időszakban más kelet- vagy közép-európai kommunista államokkal összehasonlítva a jugoszláv hadsereg és párt közötti intézményi határvonalak "elmosódottabbak" és "átjárhatóbbak" voltak. A civil-katonai kapcsolatok a rendszer jellege miatt pedig szélesebb körüek és komplexebbek, mint egy egyszerü pártelit-katonai elit viszony Fontos ugyanakkor megjegyezni, hogy a JNH-elitet a civil (párt)vezetés kooptálta a politikai döntéshozatal magas szintü testületeibe, nem pedig a katonai vezetés "erőltette rá magát" a párt csúcsvezetésére (Dean 1982, 85-86, Remington 1985, 5960). Johnson szerint a katonaság Tito halálakor politikai szereplö volt, de nem politikai "döntőbíró" (Johnson 1982, 194).

\subsection{A Tito utáni időszak (1980-1987)}

A Titót követő új állami és politikai vezetés számára két, az évtized egészét meghatározó válságfolyamat jelentett folyamatos kihívást. Az első fokozatosan mélyülő gazdasági válság volt, melynek kialakulásában Tito gazdasági inkompetenciája is szerepet játszott, és amely gyorsan sajátos dilemmahelyzettel szembesítette a politikai vezetőket. Nem lehetett ugyanis egy időben a néhai elnököt a Tito-mítosz propagálásával a rendszer egyik szimbolikus tartópillérévé tenni és "gazdasági bűnbaknak" kikiáltani (Remington 1985, 66-67, Gow 1992, 62-64). A második elhúzódó válságfolyamatot Koszovó kérdése jelentette. 
1981 márciusában és áprilisában véres zavargások robbantak ki a többségében albánok lakta autonóm tartományban, amelyet csak a hadsereg és a munkásmilícia bevetésével tudtak leverni. A halálos áldozatok számát nem hivatalos források több százra is tették. Belgrád hadiállapotot hirdetett ki a tartomány egész területére és a megmozdulások kiújulásának megakadályozása érdekében a későbbi években is jelentős számú katonai és belbiztonsági erőket kellett Koszovóban állomásoztatni. Azzal, hogy a (szerbiai és szövetségi) párt- és állami vezetés egy szerteágazó, politikai, gazdasági, szociális és demográfiai aspektusokat is magában foglaló problémakört kizárólag (bel)biztonsági kérdésként kezelt, nem csak a szerb-albán kapcsolatok további elmérgesedéséhez vezetett, hanem a tartós "rendteremtő" misszió jelentős költségekkel is járt, melyet a 80 -as évek szinte permanens gazdasági válságának körülményei között kellett az országnak előteremtenie (Vasic 1996, 121, Gow 1992, 64-70). A koszovói válság újabb érvet szolgáltatott a hadsereg azon vezetőinek is, akik már Tito elnökségének utolsó éveiben következetesen hangoztatták a védelmi kiadások növelésének szükségességét, egyebek mellett a Szovjetunió afganisztáni beavatkozására hivatkozva.

A jugoszláv államfő halálával rövid időn belül két, a hadsereget alapjaiban érintő változásra került sor. A föparancsnoki szerepkört a kollektív államelnökség vette át, melynek elnöki pozícióját rotációs alapon minden évben a testület másik tagja töltötte be. Az 1982-ben elfogadott honvédelmi törvény is kodifikálta azt a lehetőséget, hogy a honvédelem napi szintű irányítását a testület a szövetségi védelmi miniszterre ruházhatja. Az egyszemélyi föparancsnok "kiesése" a rendszerből nagy mértékben növelte a védelmi miniszter és a katonai vezetés mozgásterét, különösen, ami a védelem napi irányítását illeti (Remington 1985, 6162). A második változtatás az úgynevezett Területvédelmi Tanács 1980 májusi létrehozása volt, melyet a tagköztársasági és tartományi Területvédelmi Erők parancsnokai mellett a JNH vezetés egyes tagjai (például a vezérkari főnök vagy képviselője) valamint a védelmi minisztérium magas beosztású képviselői alkottak. A tanács létrehozásával gyakorlatilag befejeződött a Területvédelemnek a JNH vezetése alá történő intézményi-politikai "betagolása" (Remington 1985, 60-61, Milivojevic 1988, 34-37).

A katonai elit alapvetően támogatta a szövetségi kormány először 1982-ben megindított -később sikertelennek bizonyult- különböző gazdasági stabilizációs programjait, noha mindvégig hangoztatták, hogy az államháztartás rendbetétele nem 
jelentheti a katonai kiadások csökkentését (Stankovic 1984b, Remington 1985, 6669). Magas rangú katonai vezetők, közöttük Branko Mamula tengernagy, szövetségi védelmi miniszter, a 80-as évek első felében ugyanakkor mind gyakrabban bírálták a szövetségi állami és pártszerveket a gazdasági stabilizációs program következetlen végrehajtása, valamint a tagköztársasági párt- és állami vezetőket a helyenként fegyveres erőket is elérő erősödő nacionalista tendenciák tolerálása, illetve "a szük tagköztársasági részérdekek előtérbe helyezése" miatt. A katonai elit kritikáit részben az általános gazdasági-politikai-társadalmi válság kapcsán az ország védelmi képességének meggyengülése miatti aggodalom is motiválta. (Milivojevic 1988, 1516, 25-27, Stankovic 1983, Gow 1992, 70-72) A hadsereg jelentősen megnövekedett politikai "láthatóságával" összefüggésben pedig mind jugoszláviai mind pedig külföldi megfigyelök is több esetben vetették fel a hadsereg politikai beavatkozásának, a válság további elmélyülése esetén pedig a katonai hatalomátvétel lehetőségét (Lásd pl., Remington 1985, Milivojevic 1988).

A hadsereg politikai beavatkozásának kérdését azonban a 80-as évek elejének jugoszláv kontextusában kell értelmezni. Mint korábban említettem, a hadsereg politikai részvétele a jugoszláv pártállam rendszerében intézményesítve volt, egyebek mellett a hadsereg pártszervezetének viszonylag autonóm pozíciója és számukra garantált KB-tagi helyek révén.

A hadsereg "politikai beavatkozásának" alkotmány által megengedett mértéke Jugoszláviában mind a szovjet típusú kommunista rendszerekben, mind pedig a nyugati államokban megszokottnál jóval szélesebb volt (Gow 1992, 72-73). Ezt a berendezkedést pedig - számos ún. "harmadik világbeli" országtól eltérően - nem a katonai elit erőltette rá a civil politikusokra, hanem a 70-es évekbeli civil párt- és állami csúcsvezetés hozta létre. Így tehát "az alkotmányos rend védelme", ahogyan a hadsereg saját politikai misszióját megfogalmazta, magában foglalta a hadsereg abban rögzített politikai részvételének védelmét is. (Gow 1992, 72-73)

Ugyanakkor, mint James Gow rámutat, noha a hadsereg rendszeresen felemelte a szavát az általa nemkívánatosnak tartott politikai trendek ellen (például a nacionalizmus vagy a "tagállami részérdekek előtérbe helyezése az összjugoszláv célokkal szemben"), ennél többet alapvetően nemigen tehetett. Egyfelől, a korábbi válságperiódusokban (például a "horvát tavasz" idején) a katonai elit a "civil" politikai elit egyik befolyásos csoportjával - általában Tito és legközelebbi munkatársai - közösen fellépve tudták érdekeiket érvényesíteni, most pedig a JNH- 
vezetés csak egy volt az egymással vetélkedő politikai érdekcsoportok közül (Gow 1992, 74-75). Másfelöl, a 80-as évekre több okból megrendült a JNH korábban rendkívül erős belső legitimitása. Gow négy tényezőt sorol fel, amelyek ebben közrejátszottak: az összjugoszláv gondolat társadalmi elfogadottságának csökkenése, a partizánháború politikai legitimáló erejének megrendülése, a JNH (különösen annak tisztikara) etnikailag-társadalmilag nem kellően reprezentatív jellege, valamint a növekvő hadseregellenes érzelmek, föként Szlovéniában és a fiatalok körében (Gow 1992, 74-77). E helyütt a fenti tényezők közül kettőről kell bővebben szólnom: a tisztikar etnikai összetételének kérdéséről, valamint a fiatalok körében megerősödő hadseregellenes érzelmekről. A háború előtti jugoszláv királyi hadsereg tisztikara kevés kivétellel a szerb etnikumból tevődött ki, a tábornokok esetében pedig 165-ből 161 fö tartozott ehhez a nemzetiséghez. (Gow 1992, 115) A titói időszakban kísérletek történtek a tiszti és tábornoki állomány etnikailag reprezentatívabbá tételére, azonban különböző okok miatt (történelmi előzmények, a katonai pálya eltérő társadalmi presztízse az egyes tagköztársaságokban, a jól fizető alternatív munkalehetőségek körének szélesebb vagy szükebb volta stb.) a tisztikarban mindvégig többséget alkottak a szerb és montenegrói etnikum tagjai. A magukat "jugoszlávnak" vallók népszámlálási kategóriája a jugoszlávista eszmeiséggel azonosulók mellett elsősorban a vegyes házasságból származókat foglalta magában, de több szerző szerint (Bebler 1991, Gow 1991, 302) a "jugoszlávok" többsége etnikailag szerb volt. A szerb és montenegrói mellett a "jugoszláv" etnikai csoport tagjai is számarányukat messze meghaladó mértékben képviseltették magukat a JNH tisztikarában (lásd 3. és 4. táblázat) A szerbek és montenegróiak felülreprezentáltsága, valamint az egyéb nemzetiségek (közöttük a szlovénok és horvátok) alulreprezentáltsága azonban eltérő mértékű volt a katonai ranglétra különböző szintjein. Elemzési szempontból érdemes külön bontani a tisztikar egészét, a tábornoki kart, valamint a haderő legszükebb csúcsvezetését.

A föparancsnokság a JNH legszükebb csúcsvezetését ölelte fel, ide sorolhatók a szövetségi védelmi miniszter és helyettesei, a vezérkari főnök és helyettesei, a katonai körzetek parancsnokai, az államfö (1980-ig Tito, majd a kollektív államföi testület) katonai tanácsadói, valamint a JNH pártszervezetének vezetői, összesen kb. 30 fö. 
2. táblázat: A Jugoszláv Néphadsereg tisztikarának etnikai összetétele 1971-ben (\%)

\begin{tabular}{|l|c|c|c|c|}
\hline \multicolumn{1}{|c|}{ Nemzetiség } & Lakosság & Tisztikar & Tábornokok & Főparancsnokság \\
\hline Szerb & 41,7 & 60,5 & 46,0 & 33,0 \\
\hline Montenegrói & 3,0 & 8,0 & 19,0 & 8,3 \\
\hline Horvát & 23,0 & 14,0 & 19,0 & 38,0 \\
\hline Szlovén & 8,5 & 5,0 & 6,0 & 8,3 \\
\hline Macedón & 7,0 & 6,0 & 5,0 & 8,3 \\
\hline Bosnyák (Muszlim) & 6,5 & 3,5 & 4,0 & 4,1 \\
\hline Albán & 6,0 & 2,0 & 0,5 & 0,0 \\
\hline Egyéb & 4,3 & 1,0 & 0,5 & 0,0 \\
\hline
\end{tabular}

Forrás: Zdenko Antic: National Composition of the Yugoslav Army Leadership, Radio Free Europe Research, 1972. április 12., 3. oldal

\section{3. táblázat: A Jugoszláv Néphadsereg tisztikarának etnikai összetétele 1981-ben (\%)}

\begin{tabular}{|l|c|c|}
\hline \multicolumn{1}{|c|}{ Nemzetiség } & Lakosság & Tisztikar \\
\hline Szerb & 36,3 & 60,0 \\
\hline Montenegrói & 2,6 & 6,2 \\
\hline Horvát & 19,7 & 12,6 \\
\hline Szlovén & 7,8 & 2,8 \\
\hline Macedón & 6,0 & 6,3 \\
\hline Bosnyák (Muszlim) & 8,9 & 2,4 \\
\hline Albán & 7,7 & 0,6 \\
\hline Magyar & 1,9 & 0,7 \\
\hline Jugoszláv & 5,4 & 6,7 \\
\hline Egyéb & 3,7 & 1,6 \\
\hline
\end{tabular}

Forrás: Saját szerkesztés Anton Bebler: Political Pluralism and the Yugoslav Professional Military. In: J. Seroka and V. Pavlovic (ed.): The tragedy of Yugoslavia. The failure of democratic transformation. (M.E. Sharpe, Armonk, NY, 1993) 117. oldal és S.P. Ramet: Nationalism and federalism in Yugoslavia, 1962-1991 (Indiana University Press, Bloomington, 1992) 20. oldal alapján

\section{4. táblázat: A Jugoszláv Néphadsereg tisztikarának etnikai összetétele 1990/91-ben (\%)}

\begin{tabular}{|l|c|c|c|c|c|}
\hline Nemzetiség & $\begin{array}{c}\text { Lakosság } \\
(1991)\end{array}$ & $\begin{array}{c}\text { Tisztikar } \\
(1990)\end{array}$ & $\begin{array}{c}\text { Tábornokok } \\
(1991)\end{array}$ & $\begin{array}{c}\text { Ezredesek } \\
(1991)\end{array}$ & $\begin{array}{c}\text { Alezredesek } \\
(1991)\end{array}$ \\
\hline Szerb & 36,2 & 54,3 & 50,3 & 64,5 & 64,5 \\
\hline Montenegrói & 2,3 & 5,2 & 12,4 & 11,0 & 6,8 \\
\hline Jugoszláv & 3,0 & 9,6 & 4,6 & 5,3 & 7,0 \\
\hline Horvát & $\mathbf{1 9 , 7}$ & $\mathbf{1 2 , 5}$ & $\mathbf{1 4 , 4}$ & $\mathbf{9 , 4}$ & $\mathbf{9 , 3}$ \\
\hline Szlovén & $\mathbf{7 , 5}$ & $\mathbf{2 , 3}$ & $\mathbf{7 , 8}$ & $\mathbf{3 , 1}$ & $\mathbf{2 , 4}$ \\
\hline Macedón & 5,8 & 7,3 & 7,8 & 4,4 & 6,5 \\
\hline Bosnyák (Muszlim) & 10,0 & 5,3 & 2,0 & 1,2 & 1,8 \\
\hline Albán* & 9,3 & 1,5 & 0,7 & 0,2 & 0,2 \\
\hline Magyar & 1,6 & 1,0 & 0,0 & 0,3 & 0,2 \\
\hline Egyéb & 4,6 & 1,4 & 0,0 & 0,8 & 1,2 \\
\hline
\end{tabular}

*: Az albánokra vonatkozó népességi adat becslés, mivel többségük bojkottálta az 1991-es népszavazást.

Forrás: saját szerkesztés Juhász József: Volt egyszer egy Jugoszlávia (AULA, Budapest, 1999), 326. oldal, Lenard J. Cohen: Broken bonds. The dissolution of Yugoslavia (Boulder, Westview, 1995), 182. oldal, valamint James Gow: "Deconstructing Yugoslavia" In: Survival Vol. 33. No. 4. (1991), 302. oldal alapján 
Mint a 2. táblázaton látható, ezen a szük személyi körön belül a hetvenes évek elején a szerbek alulreprezentáltak, a horvátok pedig felülreprezentáltak voltak, a szlovénok és macedónok aránya nagyjából megfelelt a lakosságon belüli számarányuknak, míg a montenegróiak ugyan felülreprezentáltak voltak, de ennek mértéke kisebb volt, mint a tábornoki kar esetében (Antic 1972, 3-5). A montenegróiaknak a tábornoki karon belüli kiemelkedő aránya arra vezethető vissza, hogy a hetvenes években a tábornokok nagy része a partizánháború egykori résztvevői közül került ki, amelyben pedig a montenegróiak igen jelentős szerepet játszottak (Antic 1972, 4). A tisztikar egészét, valamint a tábornoki kart tekintve ugyanakkor egyértelműen megállapítható a jelentős szerb és montenegrói számbeli túlsúly. A 3. táblázat és 4. táblázat alapján, amely az 1981-re és 1990-91-re vonatkozó adatokat tartalmazza, a fent említett trendek alapvetően tartósnak tekinthetők. Sőt, ezen túlmenően a táblázatok és Gow (1992, 76-77) adatai alapján a 80-as években a katonatiszti pálya további "leértékelődése" volt tapasztalható a szlovénok és horvátok körében.

Összegzésként tehát megállapítható, hogy a katonai rendfokozati "piramis" csúcsa felé haladva nőtt a tisztikar etnikailag reprezentatív jellege, a nem szláv etnikumok különösen az albánok- általános alulreprezentáltsága mellett különösen a tábornoki alatti fötiszti karban (az alezredesek és ezredesek soraiban) találkozhatunk 60-70\%os szerb és montenegrói túlsúllyal (lásd 4. táblázat és Johnson 1982, 192). A montenegróiak és a "jugoszlávok" pedig általánosságban a katonai hierarchia minden szintjén a lakosságon belüli számarányukat messze meghaladó mértékben képviseltették magukat. A legfelsőbb pozíciók betöltőinek etnikai hovatartozását illetően ugyanakkor azt is lényeges megemlíteni, hogy 1967-től (amikortól a pozíciót mindvégig katonai karriert befutott tábornokok és nem tábornoki ranggal "felruházott" civil politikusok töltötték be) minden védelmi miniszter, valamint az 1945 utáni vezérkari főnökök túlnyomó többsége is a szerb etnikumból került ki. Ezen túlmenően kiemelendő, hogy a 80-as évek végére kialakult egy befolyásos, szerb nemzetiségü nyugalmazott tábornokokból álló személyi kör, így például Nikola Ljubičić és Branko Mamula (volt védelmi miniszterek), Stevan Mirković és Petar Gračanin (volt vezérkari főnökök), akik igen korán elkötelezték magukat Milosevics és az általa képviselt nagyszerb politikai program mellett (Gow 1992, 143). Mindez pedig "alátámasztotta" azt a szlovén és horvát percepciót, amely a JNH-t egyre inkább egy alapvetően szerb intézményként látta. (Gow 1992, 75-76). 
A haderő, illetve a tisztikar etnikailag nem reprezentatív jellege pedig annak politikai-társadalmi legitimitására is negatív hatással volt, a JNH és a szlovénok, illetve az albánok közötti táguló "pszicho-szociális szakadék" (Gow 1992, 110-111) pedig a hadsereg alapfunkciójának eredményes ellátását is megnehezítette (Gow, 1992, 106-111).

A hadseregellenes érzelmek szlovéniai kialakulásában szerepet játszott a tagállam földrajzi fekvése is: Jugoszlávia legnyugatibb tagköztársaságaként a viszonylag nyitott politikai rendszer körülményei között elöször a szlovén társadalom került kapcsolatba a nyugati társadalmi-kulturális trendekkel. A nyolcvanas évek második feléig - hasonlóan a nyugati társadalmakhoz - föként egy ifjúsági ellenkultúra képviselte a hadseregellenes nézeteket Szlovéniában, melynek a fő csatornája a Mladina címü hetilap, a Szocialista Ifjúsági Szövetség orgánuma volt. A JNH-val szembeni kritikák azonban már ekkor is többször túlléptek a hagyományos pacifista érvrendszeren. A hadsereg ifjúsági kritikusai bírálták annak túlzottan centralizált jellegét, a szerbhorvát vezényleti nyelv kizárólagos használatát, a sorkatonai szolgálat körülményeit, a jugoszláv hadiipar afrikai fegyverüzleteit, valamint a tisztikar soraiban uralkodó korrupciót. Követeléseik közé tartozott továbbá a lelkiismereti szolgálatmegtagadás és a polgári szolgálat lehetővé tétele is, mely tabunak számított a JNH-vezetés számára (Stankovic 1984, Gow 1992, 76-77). A katonai költségvetés kérdése azonban már az 1980-as évek első felében is többször vitára adott okot a tagállami vezetők -közöttük a szlovénok-, a szövetségi kormány és a védelmi minisztérium között. (Lásd pl. Stankovic 1982). Noha a JNH-vezetés egy ideig eredményesen lobbizott a katonai kiadások csökkentése ellen, a gazdasági válság a védelmi szférában is éreztette hatását: a fegyverzet- és felszerelésmodernizáció lelassult, egyes területeken leállt, az időszak során mindvégig magas (és növekvő) infláció pedig csökkentette a tisztek fizetésének vásárlóértékét, amely különösen az alacsonyabb rendfokozatúak esetében jelentett lényeges problémát (Gow 1992, 102-106).

A 80-as évek közepén a fokozódó köztársaságközi viták közepette a JNH volt a legerősebb kohéziójú "összjugoszláv" intézmény, de Jugoszlávia átfogó legitimációs válsága a hadsereget sem hagyta érintetlenül. A fentebb részletezett tényezők miatt a JNH politikai legitimitása megrendült, a mélyülő gazdasági válság és az erősödő nacionalista tendenciák pedig negatívan befolyásolták a védelmi képesség ellátásához köthető funkcionális legitimitását is. 
Nem sikerült továbbá a jugoszláv rendszer egyik alapvető belső ellentmondását sem feloldani: a decentralizált, "önigazgató" társadalom és politikai berendezkedés végső garantálója egy olyan intézmény (a JNH) volt, mely nem volt, és természetéből fakadóan nem is lehetett önigazgató (Gow 1992, 114-117, Remington 1985, 64). Ezen körülmények között lépett be Jugoszlávia létezésének utolsó éveibe.

\subsection{A JNH és Jugoszlávia utolsó évei (1987-1991)}

A jugoszláv állam létezésének utolsó néhány évét a tagköztársasági nacionalizmusok felerősödése, valamint az átfogó politikai-társadalmi válság megoldására születetett elképzelések közötti vita jellemezte. Eközben a Jugoszláv Néphadsereg vezetése számos olyan lépést tett, melyet, noha az a szándék motivált, hogy megörizzék, illetve helyreállítsák Jugoszlávia állami egységét, ezen lépések azonban az eredeti szándékokkal ellentétes hatással jártak. A JNH politikai szerepének vizsgálata előtt hasznosnak tartom röviden áttekinteni a 80-as évek végének politikai helyzetét és a föderáció reformjára született egymással vetélkedő elképzeléseket. Mint korábban említettem, a 80-as évek válsága mind a rendszer, mind pedig a hadsereg legitimációjának megrendüléséhez vezetett. A rendszer, ezen belül konkrétan a párt mélyülő legitimációs válsága két formát öltött. A "vertikális" legitimációs válság alapvetően azt jelentette, hogy az állampolgárok és a párt tagjai is egyre nagyobb mértékben vesztették el bizalmukat a JKSZ-ben, és annak a válság megoldására való képességében. A többi állampárti rendszert is jellemző "vertikális" mellett Jugoszláviában érzékelhető volt egy "horizontális" legitimációs válság is: a hat tagköztársaság és a két tartomány vezetése egyre kevésbé bízott egymásban és a szövetségi kormányzatban, és egyre inkább saját "tagállami" érdekeit igyekezett érvényesíteni, akár a szövetségi központ rovására is. (Cohen 1995, 47)

A 80-as évek második felében három különböző elképzelés formálódott ki a jugoszláv államot sújtó mély gazdasági és politikai válság megoldására, amelyek a szlovén KSZ, a Milosevics-féle szerb vezetés, valamint az Ante Marković vezette szövetségi kormány (SIV) nevéhez füződtek. (Cohen 1995, 51) A recentralizációt kitüző Milosevics-féle szerb stratégia alaptézise az volt, hogy az 1974-es alkotmány által megteremtett politikai rendszer nemcsak a föderáció működését ássa alá, hanem a szerb nemzet / nép érdekeit is súlyosan sérti az által, hogy Szerbián belül Koszovó és a Vajdaság széles körü tartományi autonómiát élvez. 
A politikai rendszer terén Milosevics célul tűzte ki a koszovói és vajdasági autonómia leépítését, összállami szinten pedig elmozdulást az "egy ember, egy szavazat" elve felé, amely az országban relatív többséget alkotó (viszont több tagköztársaságba és tartományba széttagolt) szerb etnikumot favorizálta volna. Noha a katonai elit egyes tagjai fenntartásokkal éltek Milosevics nacionalista retorikájával kapcsolatban, a JNH főtiszti karában sokan szimpatizáltak a nevéhez füződő recentralizációs stratégiával, a többpártrendszer bevezetését elkerülni igyekvő "pártok nélküli pluralizmus" gondolatával, valamint alapvetően a titói éra gazdasági berendezkedését megőrizni igyekvő, etatista gazdaságpolitikájával (Cohen 1995, 5156). A szlovén KSZ Milan Kučan nevével fémjelzett reformkommunista vezetése részben Milosevics programjára, részben pedig a tagállam sajátos helyzetére válaszul alakította ki saját koncepcióját. A szlovén elképzelés alapgondolata az volt, hogy Jugoszlávia két északnyugati köztársasága - Szlovénia és Horvátország népességarányához képest túlzott mértékben kell, hogy részt vállaljon a szövetségi állam kiadásaiból (különösen az elmaradott tagállamok és tartományok felzárkóztatására szolgáló alap befizetéseiből), valamint a Jugoszláv Néphadsereg fenntartásának költségeiből, különösen annak koszovói "rendfenntartó" missziója fényében. A hadseregellenes gondolatokat, mint említettem, kezdetben főleg egy diákokból és értelmiségiekből álló ellenkultúra képviselte, azonban az évtized végére a JNH-t kritizáló hangok a szlovén pártvezetésben is megjelentek (Gow 1992, 77$78)$.

A föderáció jövőjére vonatkozóan a szlovén elképzelés az "egy területi egység, egy szavazat" elvhez való közeledést tartotta kívánatosnak annak érdekében, hogy a szövetségi döntéshozatalban a kisebb tagállamokat ne lehessen egyszerüen "leszavazni". A Milosevics-vezetés szlovéniai kritikusai joggal mutathattak rá, hogy míg Belgrád szövetségi szinten a majorizációt egy előremutató, modern és demokratikus szervezőelvként igyekszik beállítani, minden erővel igyekszik ennek koszovói alkalmazását meggátolni. Szlovénia az "aszimmetrikus föderáció" elképzelését képviselte, amelynek keretében bizonyos kizárólagos szövetségi kompetenciák mellett minden tagállam maga dönthetné el a szövetségi központhoz füződő kapcsolatok szorosságát. Noha a ljubljanai vezetés eleinte nem támogatta a többpártrendszer elképzelését, kezdettől fogva a pluralizmus sokkal szélesebb körü alkalmazását szorgalmazták, mint szerbiai és montenegrói kollégáik. (Cohen 1995, $59-65)$ 
Az 1989 márciusától a szövetségi kormányt (SIV) vezető Ante Marković reformelképzelésének középpontjában a gazdasági piaci jellegü átalakítására tett lépések álltak. Felismerve mind a gazdasági helyzet súlyosságát, mind pedig a tagállamok gyökeresen eltérő álláspontját a politikai rendszer kívánatos átalakításával kapcsolatban, a szövetségi kormány számára 1989 folyamán a politikai kérdések viszonylag kevés figyelmet kaptak. A Marković-féle kormányzat számára tehát kulcsfontosságú volt Jugoszlávia, mint koherens gazdasági egység megőrzése, és az állam egyben tartására tett erőfeszítései miatt, legalábbis kezdetben, a hadsereg vezetésének támogatását is élvezte. A gazdasági reformlépések, különösen az 1989 végén több mint 1000\%-os infláció leszorítására tett kísérletek sikeressége miatt Marković és kormánya, legalábbis kezdetben bizonyos tagköztársaságokon és etnikumokon átívelő támogatottságot is élvezett (Juhász 1999, 215). A politizálás fő terének a tagköztársaságokba való áttevődése és az a tény, hogy azok eredményesen szabotálták el a szövetségi választások kiírását, megrendítette Marković politikai bázisát, és kevés sikerrel járt saját pártalapítási kísérlete is. Az 1990 júliusában megalakított Jugoszláv Reformerők Szövetsége a gazdasági reformok mellett a demokratikus föderáció kialakításának programjával lépett fel, a hátralévő tagköztársasági választásokat (boszniai, szerb, macedón, montenegrói) azonban a szlovénhoz és horváthoz hasonlóan a nemzeti-etnikai ügyek uralták, ezért "kevés babér termett" a Marković-féle párt számára (Juhász 1999, 210, Cohen 1995, 104). Ezen túlmenően 1990 végére a Jugoszláviát alkotó meghatározó köztársaságok vezetöi is ellentétbe kerültek Markoviccsal: mint Juhász József megállapítja, „Milosevics a reformert és a horvátot látta benne, Tudjman pedig a régi idők és a központ emberét. Gazdasági megfontolásokból fakadó, bizonyos központosító törekvései miatt megromlott a viszonya a szlovén vezetőkkel is, akik akkoriban már irtóztak mindentől, ami központi.” (Juhász 1999, 215). Jugoszlávista beállítottságuk ellenére nem alakult ki tartós partnerség Marković és a hadsereg vezetői között sem, mivel a JNH-elit tagjai gyanakvóan figyelték Marković nyugati kapcsolatait és reformer politikai beállítottságát. Juhász szerint a szövetségi kormányfő hibát követett el azzal is, hogy nem viszonyult kezdeményezőbben a nemzeti-államjogi kérdéskörhöz, hanem ignorálta azt, abban bízva, hogy a gazdasági válság enyhülésével ez a probléma „magától megoldódik” (Juhász 1999, 215, Cohen 1995, 102-104). 
Összességében tehát megállapítható, hogy a tisztikar és a katonai elit túlnyomórészt szerb származása ellenére sem volt szükségszerü a JNA-vezetés felsorakozása Milosevics és politikai programja mellett. Az ugyanakkor kezdettől fogva világos volt, hogy a központi hatalom további leépítésére, vagy a hadsereg egységének megbontására irányuló olyan javaslatokat, mint például a szlovén, a hadseregvezetés határozottan ellenezni fogja. A szövetségi kormány növekvő tehetetlensége, az állampárt felbomlását követően az alternatív „összjugoszláv” politikai opció hiánya, valamint a hadsereg intézményes túléléshez füződő érdekei miatt a JNH-Milosevics szövetség előbb vagy utóbbi elkerülhetetlenné vált. Ez a pillanat azonban csak 199091 fordulóján érkezett el (Remington 1997, 68-69).

Mint azt korábban láttuk, a JNH-vezetés és a szlovén társadalom közötti viszony már a nyolcvanas évek első felében konfliktusokkal terhelt volt. Ennek végső megromlásához azonban egy 1988-as büntetöügy vezetett. A Mladina címü hetilap 1987-ben és 1988-ban is számos, a JNH-t és annak vezetését élesen bíráló írást, vagy karikatúrát közölt. Különösen sok támadást kapott a hadsereg etiópiai fegyvereladásai (az afrikai országban ebben az időszakban éhínség zajlott), valamint a védelmi miniszter, Branko Mamula, a vádak szerint sorkatonák munkájával építtetett adriai-tengeri villája miatt. 1988. május 31-én viszont a katonai ügyészség letartóztatta Janez Janšát, a Mladina honvédelmi szakújságíróját valamint 3 társát, közöttük a JNH egy szlovén nemzetiségü tiszthelyettesét. A vádak központjában egy bizalmas katonai dokumentum kiszivárogtatása állt, mely egy feltételezett vészforgatókönyvet tartalmazott arra az esetre, ha Szlovénia területén (az 1981-es koszovói helyzethez hasonlóan) hadiállapotot kell kihirdetni. Annak a lehetősége, hogy a hadsereg vezetése terveket készíthet a reformer szlovén vezetés esetleges eltávolítására, érthetően széles körben váltott ki felháborodást Szlovéniában, a letartóztatások elleni tiltakozó megmozdulásokat pedig Milan Kučan, illetve a szlovén vezetés is támogatta. A katonai igazságszolgáltatási hatóságok azonban egy súlyos politikai következményekkel járó hibát is elkövettek: elrendelték, hogy az eljárásra a ljubljanai katonai bíróságon, de zárt ülésen és szerbhorvát nyelven kerüljön sor. Ez utóbbi döntés különösen sértő volt a szlovénok számára, és hozzájárult ahhoz, hogy a JNH-ellenesség végleg kilépjen az ifjúsági ellenkultúra keretei közül és a szélesebb társadalom mellett az elit szintjén is mainstream politikai üggyé váljon, mind a reformkommunista politikusok, mind pedig a formálódó ellenzék körében. 
Ezen túlmenően a tárgyaláson a szerbhorvát nyelv használatának erőltetése azt a régebb óta meglévő szlovéniai percepciót is megerősítette, mely a JNH-t egyértelműen Szerbiához és a szerbekhez társította (Gow, 1992, 78-88). A szlovén társadalom és a JNH közötti konfliktust tovább mélyítette a koszovói válság kiújulása 1989 tavaszán. Részben arra válaszul, hogy a Milosevics vezette szerb kormányzat 1989 márciusában alkotmánymódosítást fogadott el, mely névlegesre redukálta az albán többségü tartomány autonómiáját, ismételten véres zavargások robbantak ki Koszovóban, melyek leverésére a szerb belügyi erők mellett a JNH egységeit is bevetették (Gow 1992, 90, Cohen 1995, 107). Az újabb koszovói "rendteremtést" éles tiltakozást váltott ki Szlovéniában: a szlovén fôváros legnagyobb konferenciatermében több ezer fős, Koszovóval szolidaritást vállaló politikai rendezvényt szerveztek, ahol első alkalommal került sor a Kučan-féle vezetés és az ellenzéki politikusok közös nyilvános fellépésére. Néhány nap alatt ezen túlmenően 450 ezer fó (a szlovén lakosság majdnem $25 \%$-a!) írta alá a hadiállapot koszovói bevezetése ellen tiltakozó petíciót. A koszovói kérdéssel kapcsolatos szlovén felháborodást egyfelől motiválta egy gyors ütemben demokratizálódó társadalom "értékalapú" ellenérzése a rendőrállami módszerek ilyetén alkalmazása ellen, azonban jelen volt a "velünk is megtörténhet" kollektív érzése is, különösen, hogy az albán többségü tartományban a "rendteremtés" forgatókönyve kísértetiesen hasonló volt a Janša-per tárgyát képező dokumentumban szereplőhöz (Gow 1992, 90-91). Szlovénia és Horvátország tiltakozása szerepet játszott abban, hogy 1990 elején a szövetségi erőket teljes egészében szerbiai belügyi csapatok váltották fel Koszovóban. (Gow 1992, 127).

Az 1989-es év fő politikai kérdése a többpártrendszer bevezetése volt, amelyben a hadsereg eleinte egyértelmü elutasító álláspontot foglalt el. Egy 1989 őszi beszédében Stane Brovet altengernagy, védelmi miniszterhelyettes még úgy érvelt, hogy a formálódó új pártok egy része "nacionalista, antiszocialista, konföderalista vagy szeparatista" irányvonalat képvisel és ezért elfogadhatatlanok a JNH számára, emellett a többpártrendszer a hatalomért való versengést jelenti, ami nem segíti elő a válságból való kilábalást, hanem épp ellenkezőleg, az ország fennmaradását is veszélyezteti. Brovet és a hadsereg más prominensei több alkalommal hangsúlyozták, nem fogadják el, hogy a JNH egy "apolitikus hadsereggé válik" amely "az éppen hatalmon lévő pártot szolgálja". A kelet-európai kommunista rendszerek bukása és a legtöbb tagköztársasági pártvezető többpártrendszer iránti 
elköteleződése után azonban a JNH-csúcsvezetés álláspontja tarthatatlanná vált, néhány hónappal később egy magas beosztású katonatiszt már úgy nyilatkozott, a hadsereg "alkalmazkodik a társadalmi változásokhoz" és "nem áll az ország demokratikus fejlődésének útjába" (Cohen 1995, 87).

A hadsereg és a politikusok viszonyában gyökeresen új helyzetet teremtett a JKSZ 1990 januári 14. rendkívüli kongresszusa. A kongresszust a párt megújítása és jövőbeni irányvonalának kialakítása céljából hívták össze, azonban épp ellenkezőleg, az gyakorlatilag "beverte az utolsó szeget" az állampárt koporsójába. A hadsereg képviselői a kongresszuson egy olyan egységes föderáció mellett érveltek, melyben a JNH továbbra is politikai szerepet láthat el, és finanszírozása kellő szinten megoldott lesz. A katonai vezetés aggódott a JNH esetleges depolitizálása miatt, álláspontjuk szerint ez a JKSZ hadseregbeli szervezetének 75,000 tagja számára "a társadalmi és politikai életböl való kiközösítéssel" érne fel (Remington 1996, 161). Mivel a kongresszust az "egy ember, egy szavazat" elve alapján bonyolították le, a párt radikális reformját (például egymástól független tagköztársasági pártok szövetségévé alakítását) szorgalmazó szlovén javaslatokat a Milosevicset és szövetségeit képviselő küldöttek könnyen le tudták szavazni. Ennek hatására a szlovén delegáció kivonult a kongresszusról, példájukat Horvátország küldöttsége is követte (Cohen 1995, 84). A két delegáció kivonulását követően a Milosevics-féle blokk azt javasolta, hogy folytassák a kongresszust immáron Szlovénia és Horvátország részvétele nélkül, míg több tagköztársaság és a hadsereg KSZ-szervezete azon az állásponton volt, hogy Szlovénia és Horvátország távollétében a kongresszust el kell napolni (Remington 1997, 76, Cohen 1995, 84-85). Az ideiglenesnek szánt elnapolás véglegesnek bizonyult és 1990 első néhány hónapjában gyakorlatilag szétesett az állampárt. A JNH pártszervezetének vezetője, Petar Šimić tengernagy - aki Gow (1992, 119-120) adatai szerint közvetlenül a 14. kongresszus kudarcát követő napokban még megkísérelte meggyőzni a szlovén KSZ vezetöit döntésük felülvizsgálatáról Szlovénia mellett általában a kizárólag tagállami részérdekeket képviselő pártfunkcionáriusokat vádolta a kongresszus kudarcáért. "Az elmúlt 15 évben a szövetségi pártszervek megengedték a tagköztársasági és tartományi vezetőknek, hogy kialakítsák és megszilárdítsák szük részérdekeiket. A súlyos gazdasági válság körülményei között ezek a JKSZ-ben negatív politikai és ideológiai következményekhez vezettek" - fogalmazott Šimić a hadsereg KSZ-szervezetének ülésén (Remington 1997, 76, Gow 1991,119-120). 
A mélyen átpolitizált, párthoz kötődő hadsereg a JKSZ megszűnésével politikailag légüres térbe került. Míg korábban a honvédelmi szerepkörön túlmenően az "alkotmányos rend" (azaz a pártállam) védelme képezte a hadsereg politikai misszióját, az állampárt szétesésével a JNH egyik legitimációs bázisa is eltűnt. A radikálisan megváltozott bel- és külpolitikai (a hidegháború vége) helyzetben a katonai vezetés az állam egységét fenyegető tényezők (mint például a "nacionalizmus" és a "szeparatizmus") elleni fellépésben találta meg új létalapját. (Remington 1997, 67-69, 76, Cohen 1995, 183-184)

Ha az 1989-es évet és 1990 elejét a hadsereg vezetésében a többpártrendszer általános elutasítása határozta meg, 1990-ben számukra a fö fenyegetést a "belső ellenségként" jellemzett "szeparatista" erők - tehát a szlovén és horvát kormánypártok - jelentették (Cohen 1995, 183-184). A hadsereg kimondva, kimondatlanul új politikai missziójaként az állam egyben tartását és a belső kohézió fenntartását jelölte meg. A katonai elit és a tágabban értelmezett tisztikar egy kisebb része ugyan valószínűleg ténylegesen elkötelezett volt a szocializmus titóista modellje iránt, a többségük, különösen pedig a szerb származásúak számára a föderáció egyben tartása alapvető egzisztenciális kérdés is volt. Ezen felül a föderáció felbomlása, vagy egy laza konföderáció kialakítása azzal is fenyegetett, hogy a szerb etnikum széttagolódik az utódállamok között. Így tehát a tisztikart domináló szerbek számára az egzisztenciális- és csoportérdekek, valamint az etnikai szolidaritás összefonódott (Cohen 195, 183). Azzal, hogy a hadsereg a folyamatosan élesedő tagállamközi vitákban és az egyre inkább elmérgesedő politikai légkörben a "fennálló alkotmányos rend" védelmére szólított fel, akár szándékosan, akár akaratlanul állást foglalt a föderáció-konföderáció vitában az előbbi javára (Remington 1996, 163-164). Bebler (1991, 127) arra hívja fel a figyelmet, hogy a JNH kiállása a "szocializmus" és a centralizált föderáció mellett, teljesen diszkreditálta az intézményt a demokratizációt és a decentralizációt szorgalmazó tagállamokban.

Ebben a légkörben került sor 1990 áprilisában és májusában Jugoszlávia második világháború utáni első többpárti választására Szlovéniában és Horvátországban.

$\mathrm{Az}$ áprilisi szlovéniai voksoláson a főként mérsékelt jobboldali pártokból álló DEMOS (Szlovén Demokratikus Ellenzék) pártkoalíció győzedelmeskedett. Minden jelentősebb szlovéniai párt, de különösen a DEMOS, szorgalmazta a szlovén szuverenitás további erősítését, valamint az Európához való közeledést, ugyanakkor 
az egyoldalú elszakadást pártolók ekkor még a kisebbséget alkották.

Az új szlovén kormány kezdeményezte a szövetségi hadsereg teljes depolitizálását, a szlovén sorkatonák számára a katonai szolgálat szlovéniai letöltését, valamint a szlovén vezényleti nyelv mielőbbi bevezetését is az érintett egységeknél. (Cohen 1995, 118-119, Remington 1997, 68) Érdemes megjegyezni, hogy Veljko Kadijević szövetségi védelmi miniszter közvetlenül a választást megelőzően Ljubljanába látogatott, melyet mind az ellenzéki pártok mind pedig a reformkommunisták úgy értelmeztek, mint a hadsereg - sikertelen - kísérletét arra, hogy nyomást gyakoroljanak a köztársaságra és befolyásolják a választást (Cohen 1995, 89-92).

Horvátországban a szintén jobboldali, de a szlovén DEMOS-nál jóval markánsabban nacionalista orientációjú, Franjo Tudjman vezette HDZ (Horvát Demokratikus Közösség) nyerte a választást. Tudjman pártjának programja a Jugoszláviához való viszont illetően a konföderatív megoldást szorgalmazta, az általa javasolt laza államszövetségben egyebek mellett Horvátország nem vett volna részt a közös haderőben, valamint nem finanszírozná többé a Jugoszlávián belüli gazdaságilag elmaradott területek fejlesztését sem (Cohen 1995, 94-96). Az ellenzéki pártok szlovéniai és horvátországi hatalomra kerülésének lehetősége is motiválta a JNH azon lépését, hogy elrendelte a Szlovéniában és Horvátországban található Területvédelmi Erők fegyvereinek szövetségi fegyverraktárakba való átszállítását, hivatalosan "a lopáskárok megelőzése céljából". A müvelet Horvátországban gyakorlatilag teljes egészében lezajlott, az új szlovén kormányzat azonban sikeresen tudta, legalábbis részlegesen, elszabotálni a területvédelem lefegyverzésére irányuló lépést (Cohen 1995, 184). Nyílt szembenállásra azonban 1990 nyarán elöször Horvátországban került sor, ahol a HDZ választási győzelmét követően egyre inkább elmérgesedett a viszony az ún. krajinai szerbség és a HDZ-kormány között. A Tudjman vezette kormány hatalomra kerülése után meghirdette a rendvédelmi erők, az állami vállalatok, és a média "horvátosítását", amely számos esetben ugyan a szerb felülreprezentáció megszüntetését jelentette, ugyanakkor jelentős ellenszenvet váltott ki az érintettek körében. Tovább szította a horvátországi szerbek indulatait a Milosevics ellenőrzése alatt álló szerbiai média is. (Cohen 1995, 131). A krajinai szerbek képviselői egy autonómiáról szóló népszavazás megtartását hirdették meg, fegyveres csoportok pedig megkezdték a Knin környéki utak elbarikádozását annak érdekében, hogy a horvát hatóságok ne tudják a referendumot megakadályozni. Ez volt az ún. "rönkforradalom" (Juhász 1999 226-229, Cohen 1995, 133-135). 
A szerb irregulárisok és a horvát hatóságok közötti szembenállás kritikus pontra érkezett, amikor augusztus közepén a horvát belügyminisztérium helikoptereit a jugoszláv légierő MiG-jei fordították vissza Knin közelében. James Gow adatai alapján egy vizsgálat később azt állapította meg, hogy a vadászgépek felszállásáról a döntés alacsony szinten, az érintett légibázis parancsnoka által került sor, mely újabb bizonyítékként értékelhető arra nézve, hogy alacsonyabb szinteken a tisztikarban kezdettől fogva erősebb volt a nagyszerb politikai program iránti szimpátia (Gow 1992, 142). A MiG incidenstől eltekintve a JNH ekkor még nem támogatta a horvátországi szerb irregulárisok megmozdulását, ugyanakkor nem is tett semmit annak megakadályozására. A zágrábi kormányzat pedig ekkor még elsősorban jogi eszközökkel kívánta az ellentétet rendezni. A horvátországi incidensek, valamint a területvédelem lefegyverzésére irányuló JNH-döntés miatt 1990 végére különösen felerősödött Szlovéniában és Horvátországban a JNH-ellenes hangulat, melyet fokozott, hogy a szövetségi haderő -a szerbiai média támogatásával- aktív propagandahadjáratot folytatott az új ljubljanai és zágrábi kormányzat ellen (Cohen $1995,184)$.

A katonai elit és Milosevics nagyszerb blokkja közötti formálódó szövetség egyik jele volt a Kommunisták Szövetsége - Mozgalom Jugoszláviáért (SK-PJ) megalakítása 1990 novemberében, melyben számos aktív és nyugalmazott fötiszt mellett Milosevics felesége is szerepet vállalt. A párt egyik nyilatkozata szerint a később megrendezésre kerülő (azaz konkrétan a szerbiai és a montenegrói) tagállami választásokon, valamint egy esetleges szövetségi választásokon a "szocializmus" és a "föderalizmus" mellett kiálló pártokat fogják támogatni (Gow 1992, 140-141). Az SK-PJ ugyan nem indult az 1990 decemberi szerbiai parlamenti- és elnökválasztáson, azonban több katonai prominense, így Kadijević védelmi miniszter, közvetve vagy közvetlenül Milosevics támogatására szólítottak fel (Remington 1997, 69, Cohen 1995, 160, 187-188). Kadijević egy televíziós interjúban a szlovén és horvát fegyverbeszerzésekre utalva arról beszélt, hogy a szövetségi hadsereg nem nézheti tétlenül Jugoszlávia "libanonizálódását". A védelmi miniszter ugyanakkor arról nem szólt, hogy a krajinai szeparatisták mozgalma és 1990 végén már nyilvánvaló, külső (szerbiai) segítséggel folyamatban lévő fegyverkezésük milyen szerepet játszik az esetleges "libanonizációban". (Cohen 1995, 187, Gow 1992, 143)

A szövetségi kormányzat és államapparátus (például a szövetségi bírósági szervezet) fokozódó paralizálódása vagy tehetetlensége közepette 1990 és 1991 fordulóján a 
Jugoszláv Néphadsereg volt az egyetlen többé-kevésbé koherens és müködőképes szövetségi szervezet. A szövetségi hadsereg tisztikara azonban nem volt teljesen egységes: a fö törésvonal a titóista, a jugoszláv állam egysége mellett többé vagy kevésbé továbbra is a szocialista-kommunista eszmeiség mellett elkötelezett, illetve a nagyszerb nacionalista programmal azonosuló tisztek és tábornokok között húzódott. Utóbbi csoport értelemszerüen kizárólag szerbekből állt, viszont a titóisták soraiban számos nem szerb származású tiszt is megtalálható volt, mint például a már említett Stane Brovet (szlovén) vagy a szintén szlovén Konrad Kolšek tábornok, a JNH Szlovéniát is magába foglaló V. katonai körzetének parancsnoka az 1991-es háború idején. (Gow 1992, 140-144, Cohen 1995, 181-183, 188, Juhász 1999, 216-217, 233 234, 238-239).

Noha a kezdeti elutasítás után a hadsereg vezetése 1990-ben végül elfogadta a többpártrendszer bevezetését (Bebler 1993, 132), azonban egy 1991 elején kiszivárgott belső dokumentum rávilágított arra, a JNH-vezetés egy részének csupán felszínes és taktikai jellegü volt a politikai pluralizmus iránti korábbi elköteleződése. A hadsereg politikai részlege által készített "Aktuális összefoglaló a nemzetközi helyzetröl és a JNH sürgős feladatairól" címet viselő elemzés alaptétele az volt, hogy a kommunista rendszerek 1989-90-ben csak azon országokban buktak meg, ahol azt kívülről "importálták", míg a "szocializmust még nem győzték le" ott, ahol az belső mozgalom nyomán jutott hatalomra, így például Jugoszláviában és a Szovjetunióban (Vasic 1996, 124). Üdvözölve a Szovjetunió "egyre erőteljesebb erőfeszítéseit a szeparatizmus leküzdésére" (i.e. minden bizonnyal Gorbacsov végül kudarcba fulladt 1991 januári litvániai "rendteremtő" kísérletét), a dokumentum célul tüzte ki a JNH tisztjei számára annak elérését, hogy 1991 nyarára a Kommunisták Szövetsége Mozgalom Jugoszláviáért (SK-PJ) legyen "az ország legfontosabb politikai ereje" (Bebler 1993, 137). Tekintettel a SK-PJ tömegbázisának szinte teljes hiányára, valamint az előző évi választások eredményére, egyetérthetünk Bebler (1991, 139) megállapításával, hogy az "Aktuális összefoglaló" szerzői valószínűleg nem demokratikus úton kívánták volna ezt a célkitüzést elérni. Ugyanakkor, mint Vasic (1996, 124) megjegyzi, a tisztikar alacsonyabb szintjein igencsak csekély volt a lelkesedés a SK-PJ iránt.

A katonai vezetés és a szövetségi védelmi tárca még 1990 őszén készítette elő azt a rendeletet, amely a „törvényen kívüli fegyveres alakulatok” lefegyverzésére vonatkozott. 
Ezt azonban a Szövetségi Államelnökség csak 1991. január 9-én fogadta el, Horvátország és Szlovénia ellenszavazata mellett. A testület a hadsereg javaslatára úgy döntött, hogy elrendeli a JNH-hoz és a rendőrséghez nem tartozó fegyveres alakulatok lefegyverzését, és a JNH-t bízza meg a döntés végrehajtásával (Bebler 1991, 139). Annak ellenére, hogy a döntés formálisan a horvátországi szerb irregulárisokra is vonatkozott volna, elsődlegesen a formálódó horvát "tartalékos rendőri erők" és a tervezett nemzeti gárda lefegyverzésére irányult. Annak érdekében, hogy nyomást helyezzen a szlovén és horvát kormányra, a JNH vezetése elrendelte a két tagköztársaságban állomásozó szövetségi erők legmagasabb harckészültségbe helyezését. Mivel mind a horvát kormányzat, mind a JNH taktikai okokból ekkor még kerülni akarta a konfliktust, január végén kompromisszumos megoldás született: Horvátország ígéretet tett a tartalékos rendőri erők lefegyverzésére, míg a hadsereg visszavonta a harckészültségi parancsot. A valóságban a horvát erők lefegyverzésére nem került sor, a JNH pedig a propaganda területén folytatta Horvátország elleni "hadjáratát", a zágrábi vezetés fegyverbeszerzéseit (közöttük a Magyarországról vásárolt Kalasnyikov gépkarabélyokat) állítva negatív sajtókampányának középpontjába (Tanner 2001, 235, Silber és Little 1996, 158-159). Amikor azonban a szövetségi katonai ügyészség vádat emelt Martin Špegelj horvát védelmi miniszter ellen, a letartóztatási parancsnak nem tudtak érvényt szerezni (Cohen 1995, 189-191, Bebler 1991, 139140). Az 1991-es év tavaszán eközben több fegyveres összetűzésre került sor Horvátországban (Pakrac, Plitvice, Borovo Selo) amelyek általában a rendőrállomások hovatartozása felett robbantak ki a szerb fegyveresek és a horvát hatóságok között. A szövetségi hadsereg egységei elvben békefenntartóként érkeztek a helyszínre, hogy megakadályozza a szerb-horvát konfliktus elfajulását. Kezdetben a JNH tartotta magát ehhez a célkitűzéshez, azonban idővel vagy "védőernyőt vont" a szerb irregulárisok fölé, vagy maga is szerepet vállalt a konfliktusban a szerbek oldalán (Juhász 1999, 228, Bebler 1991, 142).

Az ország azonban több megfigyelő szerint a szerbiai politikai válság miatt került a legközelebb a katonai hatalomátvétel lehetőségéhez 1991 év márciusában. Milosevics autoriter vezetési stílusa, valamint a szerbiai média nyílt pártirányítása miatt az ellenzék tömegtüntetést hirdetett 1991. március 9-re, amit a hatóságok utóbb betiltottak. 
Miután a kivezényelt rendőri erők nem tudták a tüntető tömeget feloszlatni, az Államelnökség soros elnöke, a szerb Borisav Jović - Milosevics egy közeli munkatársa - beleegyezésével a szövetségi hadsereget rendelték ki a szerb főváros utcáira. Noha a katonaság és a tüntetők között nem került sor összecsapásokra, a szövetségi erők ilyetén "pártpolitikai" célú felhasználása nem csak Szlovéniában és Horvátországban, hanem a szerb ellenzékiek körében is nagy felháborodást keltett. Az a tény, hogy a következő nap visszarendelték az egységeket a laktanyáikba azt jelzi, hogy a fellépés utólag a katonai vezetés számára is kellemetlenné válhatott (Vasic 1995, 126). Ugyanakkor a JNH-föparancsnokság néhány nappal később egy közleményben azt állította, a szövetségi erők a jogszabályoknak megfelelően, a civil föparancsnok (az Államelnökség, és annak soros elnöke) utasítására cselekedtek (Bebler 1991, 142).

A belgrádi tömegtüntetést követően néhány nappal került sor az államelnökség rendkívüli ülésére március 12-én, 14-én, és 15-én, ahol a testület a Borisav Jović és a hadsereg vezetése által javasolt kényszerintézkedéseket tárgyalta. A javaslat szerint Szlovénia és Horvátország 48 órás ultimátumot kapna, hogy hajtsa végre a "törvénytelen" fegyveres csoportok lefegyverzéséről szóló január 9-i döntést, valamint, hogy Ljubljana egyfelől biztosítsa a Területvédelmi Erők feletti szövetségi kontrollt, valamint állítsa vissza a szlovén hadkötelezettek szövetségi hadseregbe való besorozását. Amennyiben a szlovén vagy a horvát kormányzat nem teljesítené az ultimátumban foglaltakat, rendkívüli állapot lépne érvénybe és a hadsereget hatalmaznák fel, hogy kényszerítse ki azt. A szerb-JNH javaslatot Szlovénia és Horvátország mellett Bosznia, Macedónia és Koszovó ellenszavazatával utasította el az Államelnökség, melynek hatására Jović, illetve a Vajdaság és Montenegró (Milosevics-párti) képviselője lemondott az abban viselt posztjáról (Cohen 1995, 203-206). A szerb elnök egy néhány nappal későbbi, önkormányzati vezetőknek tartott beszédében arra utalt, hogy szerinte a hadseregnek az államelnökségi felhatalmazás hiányában is fel kellene lépniük "az alkotmányos rend védelmében" és tagadta, hogy ez katonai államcsíny lenne (Cohen 1995, 202-203). Milosevics minden bizonnyal valóban abban reménykedett, hogy a szövetségi csúcsvezetés időleges - megbénulása a Szlovénia és Horvátország elleni fellépésre fogja ösztönözni a JNH-vezetést, azonban a vezérkar és a védelmi minisztérium március 19-én kiadott közleménye elutasította a hadsereg politikai szerepvállalásának lehetőségét. 
Mint Bebler megjegyzi, a közlemény azonban tartalmazott egy kitételt, miszerint "mivel a JSZSZK Államelnöksége nem fogadta el a JNH által javasolt intézkedéseket a törvénytelen milíciák lefegyverzésére vonatkozóan, a JNH nem tehetö felelössé illegális fegyveres szervezetek létrejöttéért Jugoszlávia bármely területén". Ez egyértelmü utalásként értékelhető arra nézve, hogy a JNH a jövőben is tolerálni fogja a szerb irreguláris erők tevékenységét. (Bebler 1991, 143, Cohen 1995, 205-206)

E helyütt érdemes bővebben foglalkozni azzal a kérdéssel, hogy miért nem került és álláspontom szerint miért nem kerülhetett sor katonai hatalomátvételre Jugoszláviában sem a nyolcvanas években, sem 1990-1991-ben.

Mint korábban említettem, már a nyolcvanas években több jugoszláviai és külföldi megfigyelő vetette fel a katonai hatalomátvételt mint az ország mélyülő politikai válságának egyik lehetséges következményét (lásd pl. Remington 1985, Milivojevic 1988). Az állampárt felbomlásáig, tehát 1990 januárjáig a JNH vezetői a JKSZ és az egypártrendszer keretein belül értelmezték szerepüket, ahol, mint láttuk, a "hadseregpárt” a JKSZ legnagyobb belső kohézióval bíró, legszervezettebb részét alkotta a nyolcvanas évekre. A hadsereg saját politikai missziója, "az alkotmányos rend védelme", egyben magában foglalta nemcsak az egypártrendszer, hanem katonaság a kommunista világban is igencsak széles körünek tekinthető intézményesített politikai szerepének védelmét is. A kommunista államokhoz hasonlóan ugyanakkor a JNH is mélyen átpolitizált, "ideokratikus" hadsereg volt, ahol a tisztikar politikai indoktrinációjának részét képezte a "bonapartizmus" mint "politikai főbűn" hangsúlyozása (Vasic 1996, 118). Noha, mint Remington (1985, 70) rámutat, a katonai hatalomátvétel esélye akkor nő meg amikor a "civil" politikai vezetés legitimitása kimerül, azonban annak sikeréhez szükséges, hogy a hadsereg az adott társadalom egésze, vagy legalábbis túlnyomó többsége számára legitimebb legyen, mint a hitelét vesztett civil vezetés. Ez pedig Jugoszláviában már a nyolcvanas években sem teljesült, mivel, a jugoszláv rendszer mélyülő válságával párhuzamosan a JNH legitimitása is megrendült, különösen az ország két északnyugati tagköztársaságában. A nyolcvanas évek végének egyes politikai eseményei (a koszovói hadiállapot 1989-es kihirdetése és a Janša-per) valamint a hadseregvezetés fokozódó elköteleződése a Milosevics-féle politikai program mellett pedig tovább fokozták a JNH hitelvesztését a szlovénok és horvátok körében. A legitimitásdeficiten túlmenően az esetleges puccs szervezőinek dolgát egyéb, gyakorlati tényezők is nehezítették volna, így például a tisztikar egy részének, valamint a 
sorkatonai állomány jelentős részének ilyen esetben legalábbis kérdéses lojalitása (Milivojevic 1988, 54-55), valamint, hogy a katonai vezetésnek tudomása volt a gazdasági válság súlyosságáról, és ennek megoldására a tábornokok sem rendelkeztek "csodafegyverrel” (Remington 1985, 69).

A katonai beavatkozás hiányát támasztja alá az is, ha a nyolcvanas évek eseményeit a Perlmutter és LeoGrande $(1982,787)$ által bevezetett "egyenruhás párt” fogalom segítségével értelmezzük. A köztársaságközi viták elmélyülése és a JKSZ fragmentálódása, a nyolc egymással rivalizáló tagköztársasági és tartományi politikai gépezetté alakulása megítélésem szerint nem tette lehetővé egy "lengyel forgatókönyv" megvalósulását. A katonai hatalomátvétel további nehézségei közé sorolhatjuk a fegyveres ellenállás, vagy akár polgárháború lehetőségét Szlovéniában és Horvátországban, valamint a puccs kedvezőtlen nemzetközi következményeit közötte az esetleges politikai és gazdasági szankciókat -, különösen a lengyel hadiállapot nemzetközi visszhangját alapul véve (Milivojevic 1988, 43, 53). Az állampárt 1990 januári összeomlásával a hadsereg politikailag légüres térbe került és a pártállam de facto megszünésével megrendült az intézményesített politikai pozíciója, illetve az “alkotmányos rend védelmének” hivatkozási alapja. A pártállami rendszer szétesésével így az esetleges katonai beavatkozás politikai célja sem lett volna egyértelmü (Vasic 1996, 125).

Megváltozott ugyanakkor a nemzetközi környezet is. A hidegháború befejeződésével, a kommunista rendszerek 1989-90-es bukása, és a közép-európai rendszerváltások után a nagyhatalmak 1990-91-ben akkor sem fogadták volna el egy demokratikusan megválasztott kormány (a horvát) katonai puccs útján a hatalomból való eltávolítását, ha ennek meghirdetett célja egybevág a nemzetközi közösség 1991 nyaráig képviselt irányvonalával (a jugoszláv állam egyben tartása). Kadijević és köre ugyanakkor kapcsolatot tartott Jazov szovjet védelmi miniszterrel, aki az 1991. augusztusi moszkvai Janajev-puccs szervezői közé tartozott. (Érdekes egybeesés, hogy a jugoszláv tárcavezető épp a rendkívüli állapotról szóló államelnökségi vita alatt, március 13-án látogatott Moszkvába, hogy megbeszéléseket folytasson szovjet kollégájával.) (Meier 1999, 160, Vasic 1996, 126-127, Juhász 1999, 238).

A moszkvai puccs 1991 augusztusi bukása és a szovjetunióbeli „keményvonalas” erők politikai veresége nyomán viszont végleg lekerült az a lehetőség is a napirendről, hogy egy esetleges jugoszláv katonai puccs vezetői szovjet-orosz politikai támogatást kapjanak. 
Az esetleges belső konfliktus lehetősége, valamint a puccsista rendszer várható gazdasági-politikai izolációja tehát pont a JNH-vezetés politikai céljainak (a jugoszláv állam egyben tartása és a folyamatosan mélyülő politikai és gazdasági válság kezelése) elérését nehezítette volna meg vagy tette volna lehetetlenné. Megítélésem szerint az esetleges puccs "kontraproduktív" jellege volt - számos egyéb mellett - az a legfontosabb kockázati tényezö, amely eltántorította a katonai vezetőket a hatalomátvétel megfontolásától. Éppen ezért nem tartom reálisnak Milos Vasic már 1996-ben született felvetését, hogy megfelelő politikai akarat esetén a JNH eltávolíthatta volna a hatalomból Tudjman és Milosevics kormányzatát, így “megmentve” a jugoszláv államot (Vasic 1996, 137).

Összegzésként tehát megállapítható, hogy noha az objektív feltételek (mélyülő politikai és gazdasági válság, a civil politikai vezetés gyorsuló hitel- és legitimitásvesztése) alapvetően jelen voltak (lásd például Remington 1985, 69-70), az etnikai heterogenitás, a JNH legitimitás-vesztése az ország több területén, valamint a változó külső környezet (különösen 1989/90-et követően) oda vezetett, hogy kihasználatlan és kihasználhatatlan maradt a hadsereg "politikai beavatkozási potenciálja".

Noha március végére elhárult mind a fegyveres konfliktus, mind pedig a hadsereg politikai beavatkozásának veszélye, Jović katonai beavatkozására irányuló felhívása még inkább megerősítette Zágráb és Ljubljana bizalmatlanságát a szövetségi intézményekkel szemben, valamint még inkább arra ösztönözte őket, hogy mielőbb akár egyoldalúan is - elhagyják a szövetségi struktúrákat (Cohen 1995, 206-207).

A mélyülő válság újabb hulláma május 15-én érkezett el azzal, hogy az Államelnökség Milosevics-párti tagjai leszavazták a horvát Stjepan Mesić beiktatását a testület soros elnöki posztjára, noha az előzőleg megállapított rotációs rend szerint ő következett volna. Az elnökségben kialakuló patthelyzet újra megbénította a kollektív államfői intézmény müködését. Ugyanakkor van igazság Viktor Meier azon megállapításában is, hogy a szövetségi politikai struktúrák fokozatos szétesése miatt a későbbi eseményekre könnyen lehet, hogy akkor is csekély befolyást gyakorolt volna a testület, ha a nagyszerb blokk tagjai nem szabotálják el Mesić hivatalba lépését (Meier 1999, 155-156).

Erre az időszakra már a nemzetközi közösség aggodalmát is kiváltotta a jugoszláviai válság elmélyülése, a nagyhatalmak (USA, Szovjetunió, és az Európai Közösség államai) ekkor az állam egyben tartását tartották a legfontosabb célkitűzésnek 
(Juhász 1999, 188). Ezt az üzenetet fogalmazta meg Belgrádban Jacques Santer, az EK Miniszterek Tanácsa soros elnöke és Jacques Delors az Európai Bizottság elnöke is, akik az EK bőkezű pénzügyi támogatását helyezték kilátásba arra az esetre, ha a föderáció válságára sikerül politikai megoldást találni. Azonban, mint Gow megjegyzi, azáltal, hogy síkra szállt az egységes állam megtartása mellett és elvetette a konföderáció lehetőségét, az Európai Közösség akaratlanul is megnehezítette a kompromisszum elérését. Milosevics és a hadsereg vezetői immáron azzal érvelhettek, hogy Európa is az általuk favorizált megoldás, azaz a föderatív, egységes állam mellett áll. (Gow 1992, 137, Cohen 1995, 218-220)

Néhány nappal a szlovéniai háború kitörése előtt, 1991. június 21-22-én került sor James Baker amerikai külügyminiszter jugoszláviai látogatására, aki mind a szövetségi, mind pedig a köztársasági vezetőkkel tárgyalásokat folytatott. Baker felhívta a tagköztársaságokat az egyoldalú lépésektől való tartózkodásra, nyilvánvalóvá tette, hogy az Egyesült Államok nem fogja elismerni Szlovénia és Horvátország esetleges elszakadását, ugyanakkor hangsúlyozta a békés rendezés szükségességét. Kérdéses, hogy Belgrád és a JNH-vezetés "zöld utat kapott-e" Bakertől a hadsereg későbbi szlovéniai bevetésére. Cohen szerint ez csak úgy történhetett, hogy a tábornokok nem vették figyelembe a békés rendezésre vonatkozó figyelmeztetését, vagy hogy a külügyminiszter a színfalak mögött illetve implicit módon adta beleegyezését, "amennyiben az feltétlenül szükségessé válik".

A kérdéses periódusban az utóbbi értelmezést képviselte Janez Janša szlovén védelmi miniszter, aki szerint a Baker-misszió látogatását megelőző időszakban a JNHvezetésnek nem volt olyan szándéka, hogy erővel is Jugoszlávián belül próbálja tartani Szlovéniát (Cohen 1995, 220-224).

Warren Zimmermann, az USA utolsó Jugoszláviába akkreditált nagykövete azonban visszaemlékezéseiben azt állítja, az amerikai külügyminiszter kifejezetten nyomást gyakorolt Marković szövetségi kormányföre annak érdekében, hogy ne támogassa a szlovéniai helyzet semmiféle katonai megoldását. A volt nagykövet azon a véleményen van, hogy ugyan Baker nem adott „,zöld utat” a JNH-nak és a szövetségi kormánynak a beavatkozásra, tény, hogy konkrét következményeket - például szankciókat vagy akár nyugati katonai fellépést - sem helyezett kilátásba, ha egy ilyen akcióra sor kerülne (Zimmermann 1999, 134-135, 137). 
Figyelmen kívül hagyva Washington, Moszkva és az EK figyelmeztetését, Szlovénia és Horvátország június 25-én kikiáltotta függetlenségét, Szlovénia pedig átvette a jugoszláv külső határ szlovéniai szakaszának ellenőrzését is. A függetlenség kikiáltását követően 24 órán belül a JNH egységei megkezdték a határállomások feletti ellenőrzés visszaszerzésére irányuló katonai műveleteket. A hadsereg vezetése a szövetségi kormány június 13 és június 26 közötti döntéseire hivatkozott, emiatt a szlovén vezetés elsősorban Ante Marković kormányfőt hibáztatta a konfliktus kitöréséért. Marković később azzal védekezett, hogy a hadsereg túllépte az általa adott felhatalmazás kereteit, majd egyenesen azt állította, hogy a JNH vezetői kihagyták a döntéshozatalból. (Cohen 1995, 221-222, Remington 1997, 71,77)

A szlovéniai hadmüvelet volt a jugoszlávista politikusok és katonai vezetők utolsó kísérlete az állam egyben tartására, mely kellő politikai támogatás híján kudarcot vallott. A határ-visszaszerző akció kudarca után a JNH-vezetés egy része ugyan fontolgatott egy átfogó hadjáratot Szlovénia elfoglalására és a ljubljanai kormány leváltására, erre politikai támogatást sem a többi tagköztársaságtól, sem a Milosevics-féle nagyszerb blokktól nem kapott, a bizonytalan kimenetelü puccsista fellépést pedig nem kívánta vállalni. A fegyveres konfliktus kitörése után a nemzetközi közösség is a helyzet békés rendezésére szólított fel (Juhász 1999, 235236). A szövetségi kormány és a katonai vezetés egy politikailag korlátozott célkitűzésekkel bíró és korlátozott katonai erőt képviselő kontingenst mozgósított Szlovéniában (a JNH és a szövetségi belügyminisztérium a köztársaságban állomásozó egységeit), mely politikailag, katonailag és média-szempontból jól szervezett össznépi ellenállással találta szemben magát (Juhász 1999, 236). Ironikus módon a szlovén vezetés gyakorlatilag pontról pontra az "össznépi védelem" forgatókönyvét valósította meg a szövetségi erökkel szemben, csak az "önigazgató szocializmus" helyett saját politikai programja védelmében. Remington $(1997,71)$ szerint a szlovéniai "rendteremtés" kudarca jelentősen megrendítette a hadsereg "kollektív önbecsülését" és hozzájárult a tisztikar radikalizációjához, ezzel párhuzamosan felgyorsult a nem szerb, vagy a Milosevics által fémjelzett nagyszerb programmal nem azonosuló tisztek kiválása vagy eltávolítása is. Szlovénia "elvesztése" és az 1991 augusztusi moszkvai Janajev-puccs bukása pedig végleg leszámolt a JNH-vezetésen belüli, Jugoszlávia és a szocializmus eredeti formájában való megőrzésére vonatkozó reményekkel is (Juhász 1999, 238). 
Az 1991 nyári és őszi horvátországi harcokban a JNH (illetve annak megmaradt, gyors ütemben "elszerbesedő" tiszti és szinte teljesen szerb sorkatonai állománya) már a Milosevics-féle nagyszerb politikai platform támogatójaként vett részt. Az új elképzelés szerint a jugoszláv hadseregnek immár csak azon területeket kell megvédenie, amelyek "Jugoszláviában akarnak maradni", ami a boszniai függetlenség 1992 márciusi kikiáltása előtti időszakban a horvátországi szerbséget jelentette (Juhász 1999, 238-239). Mivel a horvátországi harcokban 1991 szeptemberétől jelentős szerepet kapott a JNH-laktanyák horvát erők általi blokádja, a konfliktus "Horvátország és a JNH egymás elleni háborúja" is volt egyben. Erre az időpontra a megmaradt szövetségi erők a korábbi saját maguk által deklarált, az ország egyben tartását kikényszerítő missziójukból tulajdonképpen a "polgárháború katalizátorává" váltak. (Remington 1996, 165-166)

Jelen fejezetnek nem feladata annak vizsgálata, hogy milyen esetben nyílt volna lehetőség a jugoszláv állam valamilyen formában történő megőrzésére. Kijelenthető ugyanakkor, hogy noha a JNH-elit magatartását eredetileg az állam egyben tartásának szándéka motiválta, cselekedetei épp ezzel ellentétes hatással jártak. A szocialista föderáció titói modellje melletti (és a többpártrendszer elleni) kiállás 1988-1989-ben, valamint a katonai elit fokozódó elköteleződése a milosevicsi nagyszerb ideológia mellett 1990-91-ben hozzájárultak ahhoz, hogy 1992-re mind Jugoszlávia ${ }^{9}$, mind pedig a Jugoszláv Néphadsereg történelemmé vált (Harangozó $2015,603)$.

\footnotetext{
${ }^{9}$ Az ún. kis-Jugoszlávia (Jugoszláv Szövetségi Köztársaság) 1992 áprilisában jött létre Szerbia és
} Montenegró részvételével és 2003-ig állt fenn. Lásd pl. Juhász 1999, 255, Edmunds 2007, 98-99 


\section{A fegyveres erők szerepe a posztkommunista átmenetben}

\subsection{Nincs puccs, nincs probléma?}

A demokratizáció ún. „harmadik hullámának” (Huntington 1991) részét képezte az állampárti rendszerek felbomlása Kelet-Közép-Európában és a volt Szovjetunió területén. Tekintettel ezen rendszerek fentebb is említett, sokszor militarisztikus jellegére (lásd pl. Barany 1993, 8-9, Cottey, Edmunds, Forster 2005, 1-2), joggal merül fel a kérdés, hogy milyen szerepet játszottak a fegyveres erők a posztkommunista átmenetben, és mik voltak az átalakuló országok sajátos politikai kihívásai ezen a területen. Terjedelmi okok miatt jelen fejezetben nem tudok kitérni olyan, a vizsgált téma szempontjából jelentős kérdésekre, mint a hadsereg társadalmi legitimitásának változásai (Edmunds, Forster, Cottey, 2003, 238-245), vagy a gazdasági átalakulás hatása a fegyveres erőkre és a civil-katonai kapcsolatokra (lásd pl. Szabó 2005, 73-76). Szintén nincs lehetőségem e helyütt Oroszország, valamint a Baltikumon kívüli szovjet utódállamok részletesebb tárgyalására, melyek ezen a téren a balti, közép-európai, és a posztjugoszláv országcsoporttól eltérő fejlődési utat jártak be.

Mivel demokratizáció és a civil-katonai kapcsolatok közötti összefüggést vizsgáló elméleti szakirodalom többségében a katonai diktatúrák felbomlása után demokratizálódó országok viszonyait vette alapul, ez is közrejátszott abban, hogy a posztkommunista átmenet kezdetén az ezzel foglalkozó szerzők egy részének figyelme a hadsereg politikai beavatkozásának kérdésére irányult, és a civil-katonai kapcsolatok vizsgálatát leszükítették a haderő feletti civil kontroll problémájára (a jelenség leírását és kritikáját lásd pl. Herspring 1992). Ezt a megközelítést nevezte David Betz (Betz et al. 2001, 149) „,nincs puccs nincs probléma” jelenségnek.

Cottey és szerzőtársai (2002, 31-32) úgy érvelnek, hogy a civil-katonai kapcsolatok ilyen megközelítése túlzottan leszükíti a vizsgálandó problémát, és a demokratikus civil-katonai kapcsolatok létrehozása érdekében szükséges reformok „első és második generációját" különböztetik meg. Ebben a megközelítésben az első generáció a haderő demokratikus kontrolljának jogi-intézményes kiépítését jelenti, a második generáció pedig annak effektív müködtetését, beleértve a parlamenti kontrollt, valamint a szakmai közvélemény és a civil társadalom a katonai és védelmi kérdésekkel kapcsolatos vitákba való bevonását. 


\subsection{A fegyveres erők és a pártállami rendszerek felbomlása}

A posztkommunista átmenet a civil-katonai kapcsolatok és a fegyveres erők átalakítása terén jelentkező politikai kihívásainak bővebb tárgyalása előtt érdemes röviden megvizsgálni az átmenet alapvető jellemzőit ebből a szempontból. Mindenek előtt, mint korábban említettem, a kommunista rendszerekben a fegyveres erők politikailag alárendelt szerepet játszottak. Ez azonban a rendszer jellege miatt nem jelentette azt, hogy a kommunista hadseregek apolitikusak lettek volna. Mint Barany (2012, 222) rámutat, a posztkommunista átmenet fó feladata, a hadsereg depolitizálása, míg a katonai rendszerek összeomlása után lezajló demokratikus átalakulásokban a legfontosabb kihívás a politika demilitarizálása. Más szóval, ez esetben nem a hadsereget kell kivonni a politikából, hanem a „politikát kell kivonni” a hadseregböl (Barany 2012, 240). Az a tény, hogy az állampárti rendszerekben a fegyveres erők civil (párt)kontroll alatt álltak, az átmenet során előnyt jelenthetett (a katonai rendszerekkel összehasonlítva) a civil kontroll megteremtése szempontjából, ugyanakkor sajátos kihívásokat jelentett a demokratikus civil kontroll szempontjából. Egyfelől, a jogi elő́rások a pártállami rendszerekben sokszor csak formálisak voltak, a végső szót a párt mondta ki. Másfelől, a fegyveres erők feletti civil kontroll ezen rendszerekben egyetlen politikai szereplö, az állampárt gyakorolta, ellentétben a demokratikus rendszerek gyakorlatával, ahol a fegyveres erők feletti kontroll általában megoszlik a törvényhozó és végrehajtó hatalom között (Barany 2012, 215216).

Lényeges megemlíteni, hogy az alapvető hasonlóságok mellett a térség országai között a kommunista korszakban, különösen annak utolsó évtizedében jelentős különbségek voltak, melyek esetenként a fegyveres erők az átmenetben játszott szerepét is befolyásolták.

Barany (2012, 214-215) lényeges megkülönböztető tényezők között említi, hogy az adott állam külpolitikailag és katonailag önálló (Jugoszlávia) vagy a Szovjetunió által irányított (a Varsói Szerződés tagállamai) volt e, milyen jellegű volt a kommunista egypártrendszer utolsó szakasza (reformkommunista vagy „keményvonalas”), illetve tárgyalásos és fokozatos módon, vagy hirtelen került e sor a pártállami rendszer felszámolására. Daniel N. Nelson (2002b, 430-431) az adott államnak és fegyveres erejének a korábbi Varsói Szerződés rendszerében játszott szerepére hívta fel a figyelmet. 
Szabó János (2005, 64-65), részben Anton Bebler (1994, 144) nyomán a reformkommunista és keményvonalas („konzervatív”) államok mellett az egyszemélyi vezetésű és az „oligarchikus”, illetve a szilárd és az „erőtlen” civil kontroll által jellemezhető állampárti rezsimeket különbözteti meg.

A kommunista rendszerek jellege és a fegyveres erők ezekben elfoglalt szerepe miatt a posztkommunista átmenetekben a fegyveres erők nem játszottak döntő szerepet. Az átmenetet civil (reformkommunista és formálódó ellenzéki) elitek vezényelték le, a fegyveres erőknek a korábban már említett néhány kivételtől (Románia, Bulgária) eltekintve, még a kommunista rendszerek bukásában sem volt tevékeny szerepe.

Ez élesen különbözik egyebek mellett a 70-es évekbeli spanyol és portugál demokratikus átalakulástól, ahol az előbbiben a haderő, mint a Franco-rendszer egyik támasza, megkerülhetetlen szerepet játszott az átmenetben, a portugál esetben pedig maga a fegyveres erők egyik szárnya (a baloldali Fegyveres Erők Mozgalma) döntötte meg Salazar rendszerét. (Érdemes ugyanakkor megjegyezni, hogy a Fegyveres Erők Mozgalma kezdetben nem volt egyértelmüen demokráciapárti) (Agüero 1995, 3-6).

Végezetül vizsgáljuk meg azt a kérdést, hogy - a Szovjetunió kivételével - miért nem került sor katonai puccsra vagy puccskísérletre a kommunista államokban az állampárti rendszer bukásának megakadályozása érdekében. A pártállami fegyveres erők korlátozott politikai autonómiája, a korábban említett csekély társadalmi legitimitás, és a civil (párt)kontroll több évtizedes hagyományai mellett Barany (2012, 218, 240) és Danopoulos $(1995,169)$ néhány további magyarázatot is felvet. A kommunista államok hadseregei illetőleg katonai establishmentje ugyanazon problémák által szenvedett, mint az adott társadalmak: hiányzott az a belső fegyelem, szervezettség, illetve politikai cselekvőképesség, mely a harmadik világbeli országok katonai elitjét jellemezte a 60-as években. Ezen túlmenően, az állampárti rendszerek gazdasági és politikai problémái olyan mélyrehatók és súlyosak voltak, hogy a katonai elit sem rendelkezett a civilektől eltérő megoldási javaslatokkal ezek kezelésére (Huntington 1996, 7). A régióban (a balkáni országokat leszámítva) hiányzott a katonaság politikai szerepvállalásának történeti hagyománya, valamint a nemzetközi környezet a 90-es évek elején minden szempontból a demokratizációt ösztönözte. Végezetül, a politikai elit és a közvélemény mellett maga a tisztikar is meg volt győződve a demokratikus berendezkedésre való áttérés szükségességéről (Danopoulos 1995, 169). 
A szovjetunióbeli 1991. augusztusi puccskísérlettel kapcsolatban egyfelől kiemelendő, hogy néhány katonai vezető, köztük Dmitrij Jazov védelmi miniszter nem egyedül, hanem a párt keményvonalas politikusaival együtt tett kísérletet a hatalom átvételére, másfelől pedig a hadseregen belüli egység hiánya az államcsínykísérlet kudarcában is közre játszott: a Moszkva környékén állomásozó katonai egységek parancsnokai a puccs ellen foglaltak állást (Barany 2012, 218, Odom 1998, 341-346). A szovjetunióbeli - és az előző fejezetben említett jugoszláviai eseményekkel ellentétben a korábbi szovjet szatellitállamokban, mint bemutattam, kísérletet sem tett a katonai elit a demokratikus átalakulás megakadályozására. (Barany 1992, 8, Barany 1993, 155-157).

\subsection{Az átmenet politikai kihívásai a védelmi szférában}

Az átmenet során jelentkező politikai és intézményi kihívásokat három csoportba oszthatjuk: az elsőbe sorolható a depolitizálás és a tisztikar politikai lojalitásának kérdése, a másodikba a védelmi minisztériumok „civilesítése” mely összefügg a kellő szaktudással rendelkező civil szakemberek körének „kiépítésével”, illetve a harmadikba a demokratikus civil kontroll jogi-intézményes rendszerének kialakítása és müködtetése. A föderációk bomlása után létrejövő új államok esetén a fent említettek kiegészíthetőek az államépítés kihívásaival (Barany 2012, 224-225, Bebler 1994, 144-146) Constantine P. Danopoulos (1999, 2) az átalakulás három fő feladataként a depolitizációt a demokratizációt és a professzionalizációt jelöli meg. Donnelly (1996, 3) a demokratikus kontroll megteremtését, a civil-katonai kapcsolatok újjászervezését és a védelmi reformok sikeres végrehajtását tekinti a három fö kihívásnak. Andrew Cottey és szerzőtársai (2002) az átmenet során felmerülő problémákat első és második generációs intézkedésekre osztják. Az első generáció részét képezik a haderő demokratikus kontrollját szolgáló jogi és intézményi struktúrák felépítése, míg a második generációba tartoznak azon intézkedések, amelyek a védelempolitika effektív demokratikus kontrollját biztosítják. A szerzők a védelmi politikaformálásra és végrehajtásra vonatkozó képességeket, a védelmi szféra effektív parlamenti felügyeletét, illetve a civil társadalom a védelmi ügyekkel kapcsolatos vitákba való bevonását sorolják az utóbbi csoportba. (Cottey et al. 2002, 40-41) 
Az átmenet kezdeti szakaszába tartozó intézkedések közül a legfontosabb a korábbi állampárt és a hadsereg közötti intézményes kapcsolatok megszüntetése volt. Ez magában foglalta a fegyveres erőknél müködő pártszervezetek feloszlatását, és általánosságban a politikai pártok tevékenységének megtiltását a fegyveres erőkön belül, a Politikai Főosztály megszüntetését, valamint a politikai tisztek elbocsátását vagy átképzését. Ezen túlmenően a legtöbb átalakuló ország szigorú korlátozásokat vezetett be a fegyveres erők aktív állományú tagjainak politikai tevékenységére vonatkozóan, mely általában kizárta a választott tisztség viselését és számos esetben a politikai párttagságot is. (Bebler 1994, 144-145, Cottey et al. 2002, 40-41, Barany 2012, 224) Az új alkotmányok a fegyveres erők föparancsnoki jogkörét általában az államföhöz telepítették, azonban az államelnök és a kormány közötti hatásköri megoszlás országonként változott. Kevés kivétellel a civil honvédelmi miniszter intézményét az átalakuló országok a rendszerváltás kezdetén bevezették, a Szovjetunió utódállamait leszámítva ez alól csak Románia képezett kivételt, ahol 1994-ig egy aktív állományú tábornok töltötte be ezt a tisztséget. (Bebler 1994, 147, Barany 2012, 230)

A posztkommunista régióban mindössze öt állam volt - Albánia, Bulgária, Lengyelország, Magyarország, és Románia - melynek területe nem változott az átalakulás során. A föderális államok (Jugoszlávia, Csehszlovákia, Szovjetunió) felbomlása következtében számos államban a haderő általános depolitizálásának problémája kiegészült az államutódlás, és az államépítés védelmi szférát érintő kérdéseivel. (Barany 2012, 225-226)

A föderációk felbomlása által nem érintett államokban is jellemző volt, amit Anton Bebler (1994, 147) a védelmi és katonai kérdések „nemzeti emancipációjának” nevezett. Az állami függetlenség elnyerése vagy visszaállítása, illetve a fegyveres erők feletti szovjet felügyelet (és a Varsói Szerződés) megszűntével ezen államok katonai téren megjelenő önállósága nem csak csupán a stratégiai tervezés és doktrína-alkotás terén, hanem a külsőségekben is jelentkezett.

A szovjet minták helyett visszaállításra (teljesen újonnan létrejött államok esetén kialakításra) kerültek a nemzeti jellegü egyenruhák, elnevezések és egyéb szimbólumok is (Bebler 1994, 147). Az átalakuló társadalmakban a katonai téren is jelentkezett az a dilemma, hogy a széles körü személycserékre vonatkozó szándék ellenére számos esetben képzettségük miatt szükséges volt olyan katonai vezetőket megtartani, akik korábban az állampárti rendszerhez voltak lojálisak. 
További problémát jelentett a Varsói Szerződés korábbi tagállamaiban a fötiszti kar Moszkvához füződő kapcsolatainak „megszakítása”, különösen Bulgária esetében, melynek fegyveres ereje különösen szoros szálakkal kötődött a Szovjetunióhoz (Barany 2012, 225). Érdemes ugyanakkor azt is megjegyezni, hogy a katonaság lojalitása a kommunista rendszerhez és az állampárthoz több esetben csak „felszínes” volt, illetve csak egy legfelső vezetésre korlátozódott (lásd pl. Cottey, Edmunds, Forster 2002c, 254).

Vizsgáljuk meg most azon problémaköröket, melyeket Cottey és szerzőtársai „második generációs” problémáknak neveznek, azaz az effektív védelempolitikaformálás és végrehajtás, az effektív parlamenti felügyelet, valamint a civil társadalom bevonásának kérdését. (Cottey et al 2002, 40-41) Az effektív védelempolitikaformálás és végrehajtás terén a szerzők szerint a fö problémák között a szakpolitikai apparátus „civilesítésének” nehézségeit, illetve a képességek és a reális anyagi lehetőségek közötti összhangra épülő védelmi tervezés kialakítását jelölik meg. Az állampárti rendszerekben a védelmi-katonai kérdések a hadsereg „privilégiumának” számítottak, az ezzel a témával foglalkozó képzett szakértők és hivatalnokok is a fegyveres erők soraiból kerültek ki (Donnelly 1996, 12). Mindez jelentősen megnehezítette a védelmi minisztériumok „civilesítését” az átalakuló országokban, és kezdetben gyakran nyugalmazott vagy tartalékos állományú katonatisztek kerültek civil köztisztviselői pozíciókba. (Barany 2012, 231, Cottey et al. 2002, 42). A képzett szakemberek hiányán túlmenően problémát jelentett a kormányváltáskor jelentkező politikai fluktuáció, valamint, hogy a közszféra alacsony fizetései megnehezítették a tehetséges hivatalnokok megtartását és növelték a korrupció kockázatát (Cottey et al. 2002, 43). A nem egyértelmü jogi vagy alkotmányos előírások, vagy az új államok létrejöttét kísérő ,,jogi vákuum” helyzet, illetőleg az átmenet korai szakaszát jellemző éles belpolitikai ellentétek több esetben vezettek a fegyveres erők feletti felügyelettel kapcsolatos vitákhoz. Az államfö felügyeleti jogköreivel kapcsolatos vitákra került sor például Lengyelországban 1994-ben, illetve Szlovéniában 1993-1994 között. Ezek a viták sokszor a katonai vezetés újbóli „átpolitizálódásához” is vezettek (Cottey et al. 2002, 37, Barany 2012, 232, Cottey, Edmunds, Forster 2002b, 12, Szabó 2005, 71). Az új alkotmányok és törvények a fegyveres erők parlamenti kontrolljának, közöttük ennek fontos elemét képző költségvetési kontroll intézményes kereteit is rögzítették, az effektív parlamenti kontroll gyakorlása azonban számos területen korlátokba ütközött. 
Ezek között a megfelelő erőforrások hiányát (képzett szakértők, tanácsadók alacsony száma, anyagi korlátok), a parlamenti szakbizottságokban tevékenykedő képviselők gyenge informáltságát, és azt a tényt említhetjük, hogy az átmenet első szakaszában a törvényhozók alacsony prioritásként kezelték a védelmi és katonai kérdéseket (Cottey et al 2002, 45-46).

A kommunista rendszerek időszakában az egykori keleti blokk legtöbb államában teljesen hiányzott a védelmi szférával foglalkozó, nem kormányzati szereplők köre. Ez a civil társadalom általános hiányán túlmenően, a védelmi ügyek katonai monopóliumával, és az erre a területre a kommunista rendszerekben általánosan jellemző „titoktartási” kultúrával is magyarázható (Cottey et al., 2002, 46-48, Cottey, Edmunds, Forster 2002c, 259, Vankovska és Wiberg 2003, 23). Ez alól az egykori Jugoszlávia képezett kivételt, ahol a 70-es években kezdték meg a biztonsági és védelmi kérdések - az akkori frazeológia szerint az „össznépi védelem” - oktatását és kutatását öt polgári felsőoktatási intézményben (Barany 2012, 236).

Végezetül röviden szólnom kell a professzionalizáció kérdéséröl. A professzionalizáció klasszikus felfogása a szakmai standardok, a katonai funkciók hatékony ellátásához szükséges müködési modellek bevezetése vagy átvétele.

A térségben a „professzionális hadsereg” kifejezés azonban gyakrabban az önkéntes haderőre való áttérésre vonatkozott, mely különösen a NATO-csatlakozási folyamatban részt vevő államok számára vált célkitűzéssé (Cottey et al 2005, 9). Az átalakuló országok védelmi reformról szóló vitáiban a fogalom mindkét értelmezése is jelen volt. Marjan Malešič és szerzőtársai (Malesic et al 2015, 12) ennek nyomán megkülönbözetik a strukturális és a funkcionális professzionalizációt: strukturális vagy szervezeti professzionalizáció alatt a sorozottról a hivatásos hadseregre való átállást értik, míg a funkcionális professzionalizáció a fegyveres erők müködésében a magasabb szakmai standardok bevezetését, elsajátítását jelenti.

\subsection{A nemzetközi tényezők szerepe}

Az posztkommunista átmenet eltérő nemzetközi környezetben ment végbe, mint a 70-es években a dél-európai országok vagy a 80 -as évekbeli latin-amerikai államok demokratizálódása. A 70-es és a 80-as években az érintett országok demokratikus átalakulására a hidegháborús nemzetközi rendszer keretében került sor, még akkor is, ha Spanyolország, Portugália és Görögország számára az európai integrációba való 
bekapcsolódás lehetősége a demokratikus átalakulást ösztönző tényező volt. (Agüero 1995, 4, 33-34) A kommunista egypártrendszerek megszünése egybeesett a hidegháborús szembenállás megszünésével, valamint az érintett országok gazdasági és politikai válsághelyzete miatt sokkal „sürgetőbb” volt, mint a fokozatosan végbemenő dél-európai átalakulások (Agüero 1995, 4). A Varsói Szerződés egykori európai tagállamai viszonylag korán az euroatlanti integrációt nyilvánították legfontosabb külpolitikai célkitüzésüknek, és mivel a hidegháború lezárulását követően az észak-atlanti szövetség számára még hangsúlyosabbá váltak a demokratikus értékek (Bebler 2004), a NATO-csatlakozás folyamata tevékeny szerepet játszott a demokratikus civil-katonai kapcsolatok kialakításában. A szövetség első, erre is irányuló együttműködési programja az 1994-ben elindított Partnerség a Békéért (PfP) volt (Barany 2012, 237). Érdemes megjegyezni, hogy a balti államok -illetve részben Lengyelország- kivételével az átalakuló országok politikai elitje nem annyira a létező katonai fenyegetésekkel szembeni „biztosítéknak”, hanem a demokratikus nyugati államok „klubjához” való csatlakozásnak tekintette a NATO-ba való belépést, a tagság jelentősége sokkal inkább politikai (kisebb részben gazdasági), mintsem katonai volt (Barany 2012, 239, Szabó 2005, 69). A NATO-csatlakozási folyamat a demokratikus civil-katonai kapcsolatok megteremtése szempontjából is „katalizátor” szerepet játszott, mivel a gyakorlatban a NATO-tagság egyik feltétele volt a haderő feletti demokratikus kontroll rendszerének kialakítása (Born et al 2006, 6-7). Annak érdekében, hogy elősegítségek a haderő demokratikus kormányzásának kiépítését, a kilencvenes években jelentős „tudástranszferre” is sor került a nyugati államok és az átalakuló országok között, részben kétoldalú, részben multilaterális (NATO) keretek között. Ennek egyik formáját képezte az érintett országok tisztjeinek nyugati katonai felsőoktatási intézményekben történő továbbképzése (Szabó 2005, 78)

Noha időben túlmutat a demokratikus rendszerváltás szüken vett időszakán, e helyütt tartom indokoltnak röviden megvizsgálni néhány elméleti magyarázatot, melyek a nemzetközi szervezetek (elsődlegesen a NATO) az átalakuló országok katonai és védelmi szakpolitikai folyamataira gyakorolt hatását kísérelték meg értelmezni.

Melnykovska és Schweickert (2010) szerint a NATO alapvetően kétféle csatornán keresztül gyakorolhat hatást a posztkommunista államok biztonság- és védelempolitikai folyamataira: a kondicionalitás és a szocializáció révén.

A szocializáció során, intézményi- és normatranszferre kerül sor a NATO illetve az 
érintett kormányok és hadseregek közötti, kapcsolati vagy kapcsolódási (linkage) mechanizmusok által (Melnykovska és Schweikert 2010, 3).

Mint azt a bevezetőben említettem, a kondicionalitás kétféle típusát különíthetjük el: a prekondicionalitást illetve a közvetlen vagy direkt kondicionalitást. A NATO különböző együttmüködési programjai, így például a Partnerség a Békéért (PfP), illetve a NATO-bővítés folyamata során a prekondicionalitást alkalmazta, míg a direkt kondicionalitás a közép-európai régióban kevésbé volt jellemző. Néhány nyugat-balkáni állam esetében (így például Szerbia-Montenegró vagy Horvátország) a nemzetközi közösség a kondicionalitás utóbbi fajtáját alkalmazta a hágai Jugoszlávia-törvényszékkel (ICTY) való együttmüködés kikényszerítése érdekében (Edmunds 2003b, 139-140).

A NATO-hoz való csatlakozás során a kondicionalitás egyfajta szürőként is értelmezhető, mely arra hivatott, hogy biztosítsa a NATO céljainak teljesítését, valamint, hogy a csatlakozó állam és hadserege megfelelően felkészült legyen arra, hogy a szövetség keretein belül müködjön (Melnykovska és Schweikert 2010, 8).

A kondicionalitás, mint nyomásgyakorlási eszköz hatékonyságát döntően befolyásolja a kilátásba helyezett ösztönzők (konkrétan a tagsági perspektíva) hitelessége, ugyanakkor a NATO saját stratégiai érdekei pedig arra lehetnek hatással, hogy mennyire szigorúan „kéri számon” az adott tagjelölt állam esetében a szervezet a feltételek teljesítését (Melnykovska és Schweikert 2010, 8-10, Edmunds 2003b 142). Noha a prekondicionalitás eme formájának alkalmazása a posztkommunista régióban alapvetően sikeres volt, ezen eszköz korlátai is nyilvánvalók. Mindenekelőtt, a kondicionalitás nem helyettesíti a politikai akaratot a célország döntéshozói részéröl a szükséges reformok végrehajtására. Ezen túlmenően, ahhoz, hogy a NATO-hoz csatlakozó államok és hadseregeik a szövetségen belül eredményesen tudjanak müködni, hosszú távú és holisztikus szemléletü, a védelmi apparátus egészére kiterjedő reformokra van szükség. A prekondicionalitás alkalmazása ugyanakkor esetenként a pusztán feltételek teljesítésére irányuló, felszínes reformpolitika kialakulásához vezethet, például kis számú NATOkövetelményeknek megfelelő alakulatot tartalmazó, „kétszintü” hadseregek létrejötte révén (Edmunds 2003b, 142-144).

A szociál-konstruktivista iskolát képviselő Rachel A. Epstein (2005) szerint a NATO két területen gyakorolhat hatást a célországok politikai folyamataira katonai-védelmi területen. Az első a demokratikus civil-katonai kapcsolatok elősegítése, a második 
pedig a védelempolitika denacionalizálása, azaz az unilaterális, öneröre támaszkodó megoldások helyett a multilaterális, kollektív védelmi szemlélet felé történő elmozdulás (Epstein 2005, 65-66, 93). Ezen elmélet szerint a NATO kétféle eszközzel rendelkezik, mely útján belső változásokat tud kiváltani: az ún. társadalmi befolyás (social power) és az anyagi befolyás (material power). A társadalmi befolyás a szervezet által képviselt értékekkel és eszmékkel történő azonosulás elérésére irányul, míg az anyagi befolyás a különféle kézzelfogható vagy anyagi ösztönzőket - közötte a szervezetben való tagságot - jelenti (Epstein 2005, 67-68, 71). A szerző három feltételt határoz meg, aminek egyidejü teljesülése esetén a NATO által a célország belső védelempolitikai folyamataira gyakorolt hatás a legnagyobb lehet. Először, a védelempolitikai terület katonai és/vagy civil döntéshozói ún. szakpolitikai újoncok (policy novices), akiknek még nincs a szakterületük kívánatos müködtetésével kapcsolatban megszilárdult érdek- és értékrendszerük, vagy ezen a szakpolitikai területen nincsenek beágyazott intézményi-politikai struktúrák, melyek megváltoztatása jelentős érdekeket sértene (Epstein 2005, 69-70). Másodszor, a célország politikai elitjei azonosulnak a NATO által vallott értékekkel, illetve jelen van a politikai akarat vagy szándék a tagság elérésére (Epstein 2005, 71-72). Végezetül, létre tud jönni egy, helyi és nemzetközi (NATO) szereplőkből álló ún. transznacionális koalíció, mely az adott országban elősegíti a NATO értékeivel és céljaival egybevágó (például a tagság elnyeréséhez szükséges) reformok megvalósítását (Epstein 2005, 69-70, 73).

Ez az elmélet tehát azt feltételezi, hogy a NATO csak bizonyos belső feltételek fennállása esetén képes igazán hatást gyakorolni egy adott állam védelempolitikai döntéseire, de nem feltételezi szükségszerüen, hogy az adott döntésekre mindenképpen a NATO hatása (és nem attól független külső vagy belső tényezők) miatt kerül sor (Epstein 2005, 66, 97).

Alexandra Gheciu (2005, 2005b) szociál-konstruktivista elmélete szerint a NATO nemzetközi szocializációs szerepet alapvetően normák átvitele és a posztkommunista országok társadalmi és politikai szereplői általi internalizálása révén játszik (Gheciu 2005, 10-11). A normák internalizálásának három fokozata van: először a kormányzati retorikában jelennek meg, a következő lépésben intézményesítik és a jogrendbe illesztik őket, valamint megkezdődik a társadalomban való elterjesztésük, majd pedig az állami viselkedést meghatározó tényezővé válnak (Gheciu 2005, 97 98). Gheciu három csatornát jelöl meg, amely révén a NATO szocializáció szerepet 
fejt ki: az oktatás vagy tanítás (teaching), a meggyőzés (persuasion), valamint az utánzás vagy emulálás (role-playing) (Gheciu 2005, 77). Az oktatás vagy „tanítás” azt a tevékenységet jelöli, mely révén a NATO a biztonságra és védelemre, valamint a fegyveres erők demokratikus társadalomban játszott szerepére vonatkozó eszméit és értékrendjét igyekezett elterjeszteni a közép- és kelet-európai országok érintett társadalmi és politikai szereplői körében. A cél ebben az esetben egy „közös” fogalmi keret, politikai nyelv és világszemlélet kialakítása (Gheciu 2005, 88-90). A meggyőzés, részben építve a „tanítás” eredményeire már arra irányul, hogy a NATO, az általa javasolt politikai-intézményi reformok megvalósítására igyekszik a célország(ok) politikai szereplőit „rábírni”. A meggyőzés történhet arra hivatkozással, hogy a javasolt intézményi megoldások a korábban a meggyőzendő szereplők által már internalizált politikai értékekre alapulnak, hogy a NATO kompetens a biztonság-védelmi szféra ,jó kormányzása” (good governance) területén, vagy hogy hasonló helyzetü országok korábban a javasolt reformokat léptették életbe (Gheciu 2005, 91-95). Végezetül, az „utánzás” (role-playing) egyik színtere a NATO különböző együttműködési programja - így például a Partnerség a Békéért - vagy például a közös hadgyakorlatok, ahol a tagságra aspiráló államok politikai-katonai szereplői „elsajátíthatják” a szövetségen belüli gyakorlati-működési megoldásokat (Gheciu 2005, 96).

Mitől függ a NATO fentebb részletezett szocializációs mechanizmusainak hatékonysága? Gheciu szerint az oktatás vagy „tanítás” akkor a leghatékonyabb, ha a célzott politikai szereplők saját szerepfelfogása „tanulói”, azaz az érintett államok a reformfolyamat kezdetén járnak. Ezen túlmenően a „tanítás” sikerét befolyásolja, hogy az adott politikai-társadalmi aktorok mennyire gyakran vagy intenzíven találkoznak a szervezet által képviselt eszmékkel és értékekkel (Gheciu 2005, 99100). A meggyőzés hatékonysága részben függ a „tanítás” korábbi sikereitől, mivel ennek feltétele a közös világnézet és fogalmi keret, valamint a kölcsönös bizalom megléte a két fél között. Az „utánzás” mint szocializációs technika pedig akkor vezethet sikerre, ha a megcélzott aktorok intenzív részvételére épül (Gheciu 2005, 100-101).

Összegezve az elmondottakat, a NATO akkor fejtheti ki a legerősebb hatást az érintett országok biztonsági-védelmi folyamataira, ha jelen van a politikai akarat az adott országban a csatlakozás feltételeinek teljesítésére, illetve a NATO is hiteles tagsági perspektívát képes az ország számára felkínálni (Simunovic 2015, 177). 


\subsection{Fegyveres erők a posztkommunista átmenetben: összegző gondolatok}

A fegyveres erők posztkommunista átmenetben játszott szerepére vonatkozóan egyetérthetünk Andrew Cottey és szerzőtársai (Cottey et al. 2005, 13-14) megállapításával, miszerint a kommunista korszakra a civil-katonai kapcsolatok jellemző viszonylagos - de mint említettem korántsem teljes - homogenitást a rendszerváltást követően az országok közötti jelentős sokféleség váltotta fel.

Ettől függetlenül lehetőség van néhány általános, minden vizsgált országra érvényes trend felvázolására. Az erre vonatkozó egykori aggodalmakkal (lásd pl. Cottey, Edmunds és Forster 2002c, 251-252, Born et al 2006, 8-9) ellentétben a hadsereg politikai beavatkozására nem csak az általam vizsgált országokban, hanem egyik posztkommunista államban sem került sor. Annak ellenére, hogy több államban az állampárti rendszer felbomlását követő időszakban fegyveres konfliktusra került sor, vagy autoriter politikai berendezkedés épült ki, a haderő feletti civil kontroll még olyan országokban sem kérdőjeleződött meg, mint a milosevicsi Szerbia, vagy a tudjmani Horvátország. Az említett két államban az autoriter politikai hatalomgyakorlás részét képezte a fegyveres erők feletti civil (de nem demokratikus) ellenőrzés (Cottey, Edmunds és Forster, 2002c, 255-256).

A hadsereg politikai beavatkozásával ellentétben, a vizsgált országokban a demokratikus civil-katonai kapcsolatok kialakítása szempontjából jelentősebb problémát jelentett a hadsereg civilek általi “átpolitizálásának” vagy pártpolitikai küzdelmekbe való bevonásának veszélye.

Ez a jelenség eredhet a politikusok, így például az államfő és a kormány közötti hatásköri vitákból vagy nézeteltérésekből, vagy a politikai vezetők azon törekvéséből, hogy a katonai vezetést saját „,politikai hátországuk” részévé tegyék (Huntington 1996, 11, Born et al 2006b, 244-246, 253). Harmadrészt, a demokratikus civil-katonai kapcsolatok megteremtése az adott országban nehezen választható el az általános demokratizáció kérdésétől. A kilencvenes években a visegrádi és balti államok, valamint Szlovénia érték el a legjobb eredményeket e területen, míg Bulgáriában és Romániában jóval lassabban haladt a demokratikus civil-katonai kapcsolatok kialakítását célzó reformok végrehajtása (Nelson 2002b, 437-441, 445449, Cottey, Edmunds és Forster 2002c, 262-263). Szerbiában és Horvátországban ezek a reformok csak Milosevics és Tudjman 2000-es bukását követően kezdődtek meg (Cottey et al 2005, 4). 
Több esetben, így a fegyveres erőkkel kapcsolatos társadalmi attitűdök esetében, kimutatható a kommunista rendszer elöttre visszanyúló történelmi tapasztalatok befolyásoló szerepe is (Nelson 2002b, 427-428, Edmunds, Forster, Cottey 2003, 249).

Végezetül, a haderő demokratikus kontrollja, illetőleg a demokratikus civil-katonai kapcsolatok terén a vizsgált országokra jelentős hatást gyakoroltak a nyugati államok illetőleg a NATO is. Ennek mértéke azonban eltérő volt aszerint, hogy az adott ország politikai vezetése célul tűzte e ki a NATO-hoz való csatlakozást, valamint, hogy az illető állam mennyire volt elörehaladott a NATO-integrációs folyamatban. (Cottey, Edmunds és Forster 2002c, 258-259) Az átalakuló országok tapasztalatai arra is rámutatnak, hogy a haderő demokratikus kontrollját biztosító nyugati intézményes megoldások változtatás nélkül nem ültethetők át a közép-európai környezetbe, különösképpen, hogy ezen a téren a nyugati demokráciák gyakorlata is igen nagy változatosságot mutat (Born et al 2006b, 235-236, 254, Betz és Löwenhardt 2001, 3-4). 


\section{Szlovénia: „Jugoszláviából Európába”?}

\subsection{A szlovéniai rendszerváltás és az önálló szlovén haderő létrejötte (1990-91)}

Amellett, hogy azok a kihívások, melyekkel Szlovénia szembesült saját fegyveres erejének felépítése, valamint a demokratikus civil-katonai kapcsolatok megteremtése terén, részben hasonlóan voltak a többi posztkommunista újonnan létrejött államhoz, a szlovén eset számos, még a posztjugoszláv kontextusban is egyedinek számító sajátossággal rendelkezik. Ezek, mint látni fogjuk, részben a szlovén hadsereg létrejöttének módjával, részben a 10 napos függetlenségi konfliktusból, részben pedig, különösen a kilencvenes években, szlovén belpolitikai sajátosságokkal magyarázhatók. Szerepet játszott ugyanakkor a szlovén rendszerváltás jellege, és a jugoszláv politikai-katonapolitikai „örökség” is.

A jugoszláv állam létezésének utolsó éveiben, mint korábban említettem, kiéleződtek a konfliktusok a Jugoszláv Néphadsereg illetve az akkor még jugoszláv tagköztársaságként létező Szlovénia széles társadalmi csoportjai valamint politikai elitjének egy része között. A demokratikus átalakulási folyamat előrehaladtával egyre erősebb függetlenségi mozgalom nemcsak a szövetségi központtal és a JNH-val szemben határozta meg önmagát, hanem számos függetlenségpárti politikus közöttük Janez Janša későbbi honvédelmi miniszter - már igen korán úgy látta, hogy az önálló államiság eléréséhez Szlovéniának önálló fegyveres erőkre is szüksége lesz (Szilágyi 2002, 23-24). Ezen tendenciával párhuzamosan, és a JNH-ellenesség egyik következményeként az 1980-as 1990-es évek fordulóján létezett az országban egy pacifista irányzat is, mely az ország demilitarizációjában révén látta Szlovénia biztonságát garantálhatónak (Vuga 2014, 362, Szilágyi 2002, 24). Érdemes megemlíteni, hogy az 1991-es konfliktust megelőzően valamilyen szinten minden ellenzéki párt a semlegesség, valamint bizonyos mértékü leszerelés és demilitarizáció mellett emelt szót, azonban azonnali és teljes demilitarizációt csak egy radikális kisebbség akart (Szilágyi 2002, 25-26. Az ekkori demilitarizációs és pacifista törekvésekről bővebben lásd Grizold 1991).

A szlovén demokratizációs és függetlenségi folyamatban a védelmi kérdéseket és a civil-katonai kapcsolatokat érintő politikai viták eleinte jelentős szerepet játszottak. Ez részben a 80-as évek fejleményeivel, részben pedig azzal magyarázható, hogy a függetlenség elnyerésére egy rövid fegyveres konfliktust követően került sor, illetve, 
hogy a rendszerváltás és az államépítés egymással párhuzamosan zajlott (Bebler 1996, 199). Az önálló szlovén állam létezése ugyan csak 1991-től datálható, mégis számos, a szlovén hadsereg létrejöttét befolyásoló esemény az első demokratikusan megválasztott kormány 1990 tavaszi hivatalba lépéséhez köthető, így röviden szólnom kell az 1990-1991-es időszakról is. Továbbá azt is lényeges megjegyezni, hogy a szövetségtől való „eltávolodás” már a többpárti választások elött megkezdődött a védelmi és biztonsági szférában is.

A szlovén belügyminisztérium 1990 elején úgy döntött, hogy visszarendeli az összes Koszovóba vezényelt szlovén rendőrt, az utolsó egypárti parlament 1990 márciusában pedig olyan jogszabályokat fogadott el, melynek értelmében a szlovén sorkatonák kötelező katonai szolgálatukat Szlovénia területén kell, hogy letöltsék. A Szlovén Szocialista Köztársaság Végrehajtó Tanácsa (kormánya) felszólította a szövetségi védelmi minisztériumot, hogy minél elöbb intézkedjen a Szlovénia területén kívül állomásoztatott sorkatonák áthelyezéséről (Mikulic 2007, 18-21). Az önálló szlovén hadsereg kiépítéséhez segítséget nyújtott, hogy a volt Jugoszlávia számos polgári felsőoktatási intézményében 1975-től megkezdték a védelmi tanulmányok (akkori terminológia szerint az „össznépi védelem”) kutatását és oktatását. A 80-as évek korlátozott politikai liberalizációjának körülményei között a szlovéniai kutató- és oktató intézmény mely a Ljubljanai Egyetemen müködött, fokozatosan elvesztette ideológiai ,jellegét” és olyan szakmai központtá vált mely civil szemszögből és szakmailag színvonalasan elemezte -illetve időről időre bíráltaa jugoszláviai katonai és védelmi kérdéseket. Az ebből az intézményből kikerült hallgatók a szlovén állam létezésének kezdetétől a honvédelmi szféra káderigényének fontos forrását jelentették (Bebler 1996, 196-197, Grizold 2014). Mint a 4. fejezetben említettem, a Jugoszláv Néphadsereg (JNH) vezetése kifejezetten rossz szemmel nézte a szlovéniai és horvátországi, a többpártrendszer irányába mutató politikai folyamatokat, és még az 1990-es szlovén és horvát többpárti választások elött lépéseket tett annak érdekében, hogy a köztársasági Területvédelmi Erők (TV) fegyverei e két tagállamban ne kerülhessenek az általa „nacionalistának” és ,,antiszocialistának” tekintett politikai erők kezébe. Ennek egyik legfontosabb eleme a Területvédelmi Erök szervezeti felépítésének és doktrínájának radikális felülvizsgálata volt, melynek értelmében a köztársasági TV maradék önállóságát is megvonták, a területvédelem ettől kezdve a JNH decentralizált, kiegészítő vagy tartalékos erejeként müködött volna tovább. A szervezeti 
változtatások végrehajtása érdekében rendelkeztek a köztársasági TV fegyvereinek a JNH ellenőrzése alá vonásáról, valamint a hadkiegészítés és a sorozás teljes mértékben szövetségi feladattá tételéről is (Grizold 1994, 83-84, Grizold 1997, 4849, Grizold 1997b, 102 és Mikulic 2007, 28-30). A függetlenedési törekvésekkel fellépő szlovén és horvát ellenzéki pártok, illetve 1990 tavaszi hatalomra jutásukat követően az általuk vezetett kormányok ezzel ellentétben arra törekedtek, hogy akár a Területvédelem akár más köztársasági fegyveres vagy rendvédelmi erők (például a rendőrség) bázisán egy, kizárólag a köztársasági kormányoknak felelős védelmi képességet hozzanak létre. A szövetségi hadseregvezetés centralizáló, valamint a szlovén és horvát kormányzat decentralizáló védelmi törekvései szükségképpen ellentétbe kerültek egymással. Mint a következőkben látni fogjuk, a kezdeti időszakban egyértelmủen Szlovénia járt nagyobb sikerrel az önálló fegyveres erő kiépítése terén. A szlovén Területvédelem (TV) két vezetője, Drago Ozbolt vezérörnagy és Ivan Hocevar altábornagy 1990. május 15-én adták ki parancsukat a területvédelmi erők fegyvereinek JNH ellenőrzés alá vonására. Ez a döntés a JNH és a szövetségi védelmi minisztérium Katonai Tanácsának egy 1990 áprilisi rendelkezését hajtotta volna végre melynek értelmében az összes jugoszláviai területvédelmi egységet „le kell fegyverezni” (Mikulic 2007, 28-29). Mivel a jugoszláv védelmi koncepcióban szerepet szántak a helyi kormányzati szerveknek, és egyes állami vállalatoknak is (mint például a vasút), a parancs formálisan az ezen szervezetek által tárolt fegyverekre és löszerekre is vonatkozott (Mikulic 2007, 6263). A parancsot a TV vezetői titkosnak szánták, de kiszivárgása jelentős politikai és társadalmi felháborodást keltett Szlovéniában. Lényeges megemlíteni, hogy a szövetségi jogszabályok értelmében a TV parancsnoka az adott tagköztársasági államelnökségnek tartozott felelősséggel, de a szlovéniai politikai vezetés csak utólag értesült a döntésröl (Mikulic 2007, 31-32). Az újonnan megválasztott szlovén honvédelmi miniszter, Janez Janša beiktatását követően utasítást adott a helyi kormányzati szerveknek, hogy tagadják meg a lefegyverzési parancs végrehajtását (ez nagyjából 5000 db kézifegyvert érintett), Milan Kučan szlovén államelnök pedig magához rendelte Hocevar altábornagyot azzal a céllal, hogy adjon magyarázatot a lépésre. A területvédelem vezetője az államfőnek azt a nem túl meggyőző magyarázatot adta, hogy a fegyverek JNH ellenőrzés alá vételére a lopáskár megelőzése érdekében van szükség. Négy nappal az eredeti parancs kiadása után a szlovén köztársasági államelnökség megtiltotta további fegyverek átadását. Végső 
soron 16 járási TV parancsnokság egyszerủen megtagadta Hocevar parancsának végrehajtását, összességében azonban csak a Területvédelem által birtokolt fegyverek kb. 30-50\%-ának átadását sikerült megakadályozni (Mikulic 2007, 74, 205). A lefegyverzési parancs nyomán a szlovéniai területvédelem szervezete alapvetően két csoportra szakadt: a JNH-hoz lojális tisztek kisebbségére mely elsősorban a TV főparancsnokságán volt megtalálható, illetve a személyzet nagy többségére, mely az új szlovén kormány mellett állt ki (Grizold 1994, 89).

A lefegyverzési parancs elszabotálása mellett volt egy további oka annak, hogy Szlovéniában, Horvátországgal ellentétben a Területvédelmi Erők a későbbi önálló haderő alapjává válhatott, ez pedig egy konspiratív keretek között müködő, párhuzamos parancsnoki struktúra létrehozása 1990 májusában, mely a Nemzetvédelem Műveleti Struktúrái (Manevrske Strukture Narodne Zascite, MSNZ) nevet kapta (Mikulic 2007, 28-32). A MSNZ kezdetben jogi háttér nélkül, informális keretek között müködött, néhány hónappal később müködését az új ljubljanai kormány jogilag az össznépi védelemről szóló 1982-es szövetségi jogszabállyal indokolta, mely az írta elö, hogy a védelmi felkészülés nemcsak katonai hanem civil feladat is (Mikulic 2007, 34). A valóságban a szervezet, melynek vezetői Janez Janša (honvédelmi miniszter), Igor Bavcar (belügyminiszter), Vinko Beznik (a speciális rendőri erők parancsnoka) és Anton Krkovic (korábbi magas rangú köztársasági védelmi tisztviselő) voltak, azzal a céllal jött létre, hogy előkészítse az önálló szlovén fegyveres erő megalakítását, illetve megszervezze Szlovénia védelmét egy esetleges katonai támadással szemben. A MSNZ kiterjedt információgyüjtési tevékenységet folytatott a JNH szlovéniai jelenlétéröl, illetve a JNH-vezetés későbbi terveiröl. Hasonlóképp folyamatosan információkat gyüjtöttek az új szlovén vezetéssel nem együttmüködő Ivan Hocevar vezette köztársasági TV-vezetésröl is. Több esetben a MSNZ vezetői a jugoszláv katonai elhárítás (KOS) Szlovéniában müködő hálózati személyeit is be tudták szervezni. A MSNZ feladatai közé tartozott még a védelmi feladatok koordinálása a helyi önkormányzatokkal és Területvédelem helyi és regionális parancsnokságaival (melyek formálisan a TV parancsnoki lánca alá tartoztak, de a gyakorlatban az új szlovén kormányzathoz és a MSNZ-hez voltak lojálisak), illetve a TV lefegyverzését követően megmaradt fegyverek és lőszerek elszállítása konspiratív tároló- és gyüjtőhelyekre. Többek között sikerült a vasút által katonai felkészülés keretében tárolt kézifegyverek és lőszerek JNH ellenőrzés alá vételét megakadályozni, illetve a korábbi pártállami vezetés számára kialakított, 
Gotenica térségében lévő szigorúan titkos katonai bunker komplexum területén felhalmozott fegyvereket is megszerezni. (Mikulic 2007, 55-58, 62-63) Ezek utóbbi feladatokban szerepet vállaltak a Vinko Beznik által vezetett speciális rendőri erők is. (Mikulic 2007, 81-82) Lépéseket tettek egyszerübb kézifegyverek szlovéniai gyártásának megszervezésére is: a szlovéniai Gorenje vállalat például gyártani kezdte a MGV 176 típusú géppisztolyt (Mikulic 2007, 53).

A MSNZ 1990 októberéig müködött, amikor az új szlovén vezetéshez nem lojális Ivan Hocevar altábornagyot elmozdították tisztségéből, a MSNZ-t pedig összevonták az immáron Janez Slapar (kinevezése előtt tartalékos területvédelmi örnagy) által vezetett Területvédelem parancsnokságával (Mikulic 2007, 33-35, 50-53, 66-67, 7071). A MSNZ egy olyan időszakban biztosította a szlovén függetlenségi törekvések legalább részleges- védelmi megalapozását, mely a későbbi események szempontjából kritikus volt. 1990 nyarán és kora őszén az új kormányzat még nem építette ki teljes körüen politikai befolyását, a jogi keretek kialakulatlanok voltak, a Területvédelem vezetésének egy része az új kormányzattal szemben ellenséges volt, illetve időközben a jugoszláviai helyzet is tovább eszkalálódott (Mikulic 2007, 75, Gow és Carmichael 2000, 176-177). A szlovénok helyzetét javította a hírszerzés területén tapasztalható egyfajta „aszimmetria” is. A szlovén vezetők a szövetségi szerveken belüli (esetenként nem is szlovén nemzetiségü, de a szlovénok demokratizációs vagy függetlenségi törekvéseivel szimpatizáló) forrásaikból általában jó előre értesültek a belgrádi polgári és katonai hatóságok terveiröl, míg a JNH katonai hírszerző szolgálatai sokkal kisebb hatékonysággal müködtek Szlovéniában, mint Horvátországban (Gow és Carmichael 200, 179). Az etnikai összetételbeli különbség (Szlovéniában nem volt szerb kisebbség) mellett ennek nyelvi oka is volt, annak ellenére, hogy a szerb-horvát és a szlovén nyelv nem áll távol egymástól (Gow és Carmichael 2000, 177-179).

A védelmi szféra szempontjából komoly jelentősége volt a szlovén parlament által 1990 szeptember 27-én és 28-án elfogadott alkotmánymódosításoknak, melyek kimondták a szlovén köztársasági alkotmánnyal ellentétes szövetségi jogszabályok semmisségét. Ez a módosítás-csomag jogilag a szuverenitás felé tett első lépésként értékelhető. Az egyik elfogadott alkotmánymódosítás szerint a Területvédelmi Erők feletti rendelkezés, valamint a szlovén sorkatonák katonai szolgálatának szabályozása a szlovén köztársasági hatóságok kizárólagos jogköre. Ezt követően mint láttuk az új törvények alapján október elején a szlovén kormányzat a JNH 
akarata ellenére „lecserélte” a szlovén területvédelem vezetését- 1990-1991 fordulóján egyfajta jogi és nyilatkozatháború alakult ki a szlovén hatóságok, a JNH vezetése és az Ante Marković vezette szövetségi kormány között a honvédelmi politika ügyében (Kladnik 2011, 531-532). Mivel a JNH vezetőivel nem született megállapodás a szlovén vezényleti nyelvről, illetve arról, hogy a szlovén sorkatonák a tagköztársaságot magában foglaló V. katonai körzetben teljesíthessék a sorkötelezettségüket, a szlovén kormányzat lépéseket tett annak érdekében, hogy a sorkatonák kiképzését saját hatáskörben szervezze meg. A sorkötelesek első csoportjának bevonulására 1991. május 15-én került sor, mely azóta is az önálló szlovén haderő megalapításának évfordulója (Kladnik 2011, 528-530).

Az első honvédelmi törvényt és a sorkötelezettségről szóló törvényt még 1991 tavaszán fogadták el, amikor Szlovénia még Jugoszlávia részét képezte. Az előző évben elfogadott alkotmánymódosításoknak megfelelően az új törvény a szlovén Államelnökség fennhatósága alá vonta a Területvédelmi Erőket. A korábbi „önigazgató szocialista” jogi keretek helyett a jogszabály bevezette az európai mintájú állampolgári jogokat és kötelezettségeket a honvédelmet illetően, valamint először rögzítette a fegyveres erő depolitizálásának alapelvét (Grizold 1994, 84-85). Érdemes megjegyezni, hogy a törvény tartalmazott egy olyan passzust, ami alapján egy Jugoszláviát érő külső támadás esetén a szlovén TV továbbra is a Jugoszláv Néphadsereg alárendeltségében müködött volna. Ez minden bizonnyal annak folyománya volt, hogy 1991 tavaszán még volt elvi lehetőség Jugoszlávia konföderatív alapú újjászervezésére (Szilágyi 2002, 35-36). Egy további fontos, a tíz napos konfliktus alatt jelentős szerepet kapott testület volt az 1991 márciusában létrehozott, a rendkívüli állapot esetén meghozandó intézkedéseket koordináló operatív törzs, mely az államelnökség mellett müködött, és az illetékes minisztériumok, a területvédelem, a rendőrség, illetve a polgári védelem egyes vezetöit foglalta magában (Mikulic 2006, 68).

Jelen doktori értekezésben a szlovén függetlenségi háború eseménytörténetével nem foglalkozom, mivel úgy ítélem meg, hogy témám szempontjából sokkal lényegesebbek a tíz napos konfliktus előzményei és következményei, mint annak pontos lefolyása. ${ }^{10}$ Így e helyütt a konfliktus csak néhány, szempontunkból releváns

10 A tíznapos konfliktusról bővebben lásd magyarul pl. Juhász 1996, 16-21, Juhász 1999, 231-236, Silber és Little 1996, 209-227, szlovénul Tednik IN 1991, Svajncer 1993, angolul Mikulic 2006, Thomas és Mikulan 2006, a résztvevők visszaemlékezéseiért lásd pl. Janša 1994 
aspektusát emelem ki. Az egyik az áldozatok igen alacsony száma: a Szlovén Vöröskereszt adatai alapján a tíz nap alatt összesen 62 személy vesztette életét, amiből mindössze 8 tartozott a területvédelem és a rendőrség kötelékébe. Az áldozatok közül 39 JNH katona, míg 5 jugoszláviai és 10 külföldi civil volt, az utóbbiak jellemzően kamionsofőrök (Mikulic 2006, 117, Malesic 2005, 11).

Ezen túlmenően lényeges, hogy a rövid konfliktus során a szlovén kormányzat „kombinálta” a fegyveres és civil ellenállást (például barikádok építését, illetve a Szlovéniában lévő szövetségi laktanyák áram-, gáz-, víz- és telefonkapcsolatának megszakítását) az aktív médiastratégiával, melyben Jelko Kacin tájékoztatási miniszter kulcsszerepet játszott, és amely a JNH által elkövetett „agresszióra” kívánta a jugoszláviai és a nemzetközi közvélemény figyelmét felhívni. Ez túlmenően igyekeztek a nemzetközi közösséget is a helyzet rendezésébe bevonni: e területen a szlovénok célkitüzése az volt, hogy a nemzetközi nyomás mielőbb állítsa le a szövetségi erők szlovéniai hadmozdulatait (Grizold 1997, 49-51, Szilágyi 2002, 40-42). Így tehát a tíznapos háború Ljubljana számára kedvező kimenetele legalább annyira köszönhető annak, hogy Belgrád és a JNH számításával ellentétben (Gow és Carmichael 2000, 177-178) a szlovénok fegyveres ellenállást fejtettek ki, mint annak, hogy mint korábban említettem, nem volt valós politikai akarat a szerb és szövetségi vezetők többségében Szlovénia „megtartására”. Ez utóbbi pedig szerepet játszott abban, hogy igen gyorsan sikerre vezettek a nemzetközi közösség békés rendezésre vonatkozó törekvései is (Szilágyi 2002, 43, Gow és Carmichael 2000, 177-181).

A tíznapos háborúban aratott győzelem a fiatal állam egyik legitimációs bázisává, „eredetmítoszává” vált, és a rövid konfliktus tapasztalatai a kilencvenes években nagy hatást gyakoroltak a formálódó szlovén haderőre. Amint korábban láttuk, az egykori JNH a jugoszláv tagköztársaságok közül Szlovéniában volt a legnépszerütlenebb, a tíznapos háború - legalábbis átmenetileg - segített a honvédelem kérdését újraértékelni egy alapvetően hadseregellenes és pacifista társadalomban. (Malesic és Jelusic 2005, 211-212)

Az 1990-es választás idején, egyebek mellett a Szlovén Zöldpárt által is képviselt pacifista elképzelések az ország demilitarizálását vagy az állandó haderő felszámolását is szorgalmazták, de az 1991 nyári konfliktust követően ezek fokozatosan háttérbe szorultak. Az 1991 végén elfogadott szlovén alkotmány 124. cikkelye ugyanakkor azt tartalmazta, hogy Szlovénia védelmének a „békepolitikára és az erőszakmentesség kultúrájára” kell épülnie. Ez a kormánykoalícióban is 
résztvevő zöldeknek tett egyfajta politikai engedményként is értelmezhető volt (Bebler 1996, 201, Vankovska és Wiberg 2003, 180).

Különösen az új állam létezésének első éveiben elterjedt volt az a narratíva, amely szerint az 1991 nyári események a „katonai amatőrök” (a Területvédelem jórészt egykori tartalékos tisztekből álló vezetői és a Janez Janša honvédelmi miniszter környezetéhez tartozó politikusok) és az általuk szorgalmazott „partizán” jellegü taktika győzelmét jelentették a „professzionális” JNH-val szemben (Bebler 1996, 209). Emiatt sok esetben minimális katonai háttérrel rendelkező, de a függetlenségi harcban részt vett személyek kerültek viszonylag gyorsan az új Területvédelem fötiszti pozícióiba, a JNH volt szlovén származású tisztjei pedig akkor is háttérbe szorultak, ha teljességgel lojálisak voltak az új szlovén államhoz (Bebler 1996, 208210, Vankovska 1995, 219, Vankovska és Wiberg 2003, 173-174).

Ez a narratíva esetenként az ellenállás katonai jellegét és a Területvédelmi Erők kulcsszerepét hangsúlyozta, elfeledkezve arról, hogy az egyéb rendvédelmi szervezetek -mint például a rendőrség- szerepén túlmenően az állampolgári ellenállás is kiterjedt és jelentős volt, például barikádok építése révén (Vankovska és Wiberg 2003, 174-175).

Összefoglalva tehát, a függetlenség 1991 júniusi kikiáltását követő napokban katonai (az előző egy évben újjászervezett szlovén Területvédelem illetve a civil lakosság fegyveres és nem fegyveres ellenállása), és politikai tényezők is szerepet játszottak abban, hogy az ország gyorsan és viszonylag alacsony áldozatok árán el tudta nyerni önállóságát. A tíznapos háború miatt a kialakuló szlovén haderő szerves ,államépítő” és legitimációs szerepet játszott, amely erősebb volt, mint az olyan új államok fegyveres ereje esetében melyek függetlenné válását nem kísérte semmiféle katonai konfliktus (pl. Szlovákia). 


\section{2. Államépítés és biztonságpolitikai „útkeresés” (1991-1994)}

\subsection{1. Általános politikai trendek}

A szlovén állami függetlenség formális elnyerése egy folyamatként írható le, amely 1991 július elejétől (a tíznapos konfliktust lezáró brioni megállapodás) 1992 január 15-éig (az ország elismerése az Európai Közösség tagállamai által) datálható. Katonai szempontból ebben a folyamatban az önállóság elnyerését követően a két legfontosabb pont 1991. július 18-a, amikor Jugoszlávia államelnöksége arról döntött, hogy a Jugoszláv Néphadsereg egységeit három hónapon belül kivonják Szlovéniából, illetve október 25-e, amikor az utolsó JNH-katona kivonása ténylegesen is megtörtént (Szilágyi 2002, 59, Szilágyi 1997, 169-170).

A létrejött új szlovén haderőnek (mely egy ideig a Területvédelmi Erők elnevezést viselte és csak 1994-től vette fel a Szlovén Hadsereg nevet) számos kihívással kellett szembe néznie: a pénzhiány mellett ide sorolható az 1996-ig érvényben lévő, Szlovéniára is vonatkozó ENSZ fegyverembargó, a szakképzett hivatásos katonák hiánya, valamint az új fegyveres erök rendkívül heterogén személyi összetétele (Malesic és Jelusic 2005, 219-221, Vankovska és Wiberg 2003, 179). Mint azt Svete és Jelusic (2009, 4-5) megjegyzik, a 90-es években, különösen annak első felében a személyzeti és a technológiai probléma közül az utóbbi volt jelentősebb, mivel az embargó igencsak beszükítette a fegyverzet- és felszerelésmodernizáció lehetőségeit. A JNH szlovén származású fötisztjeinek alacsony száma és esetenként az új államhoz való kérdéses lojalitása miatt a korábbi JNH fötisztek közül igen kevés - a tábornokok közül például egy sem - került át az új szlovén hadseregbe, de alacsony volt a főtiszti rendfokozat alatti egykori JNH tisztek száma is. Az új szlovén tisztikar nagyobb része kezdetben az 1991 előtti területvédelmisek, vagy a tartalékos JNH tisztek és tiszthelyettesek soraiból érkezett, egy másik részük pedig az 1991-es konfliktus alatt vagy azt közvetlenül követően csatlakozott a katonasághoz és számottevő formális katonai képzettsége nem volt (Vankovska és Wiberg 2003, 180181, Bebler 1996, 202). A fegyveres erők már említett erőteljes „civilesedése” részben elősegítette a demokratikus civil-katonai kapcsolatok kialakulását, mivel lehetetlenné tette egy „katonai lobbi” létrejöttét, rendkívül negatívan hatott ugyanakkor a fegyveres erök professzionalizációjára, mely utóbbi különösen az évtized második felében jelentett problémát. Mint a következőkben látni fogjuk a 
szilárd civil és demokratikus kontroll kiépítése nem jelentette azt sem, hogy a hadsereg teljességgel mentessé vált a pártpolitikától (Bebler 1996, 209-210).

Az új állami keretek között bizonyos, a fegyveres erőkkel kapcsolatos korábbi gyakorlatok, intézmények fennmaradtak (mint egy ideig maga a Területvédelmi Erők elnevezés), azonban számos példa volt arra is (így például a lelkiismereti szolgálatmegtagadás európai viszonylatban is igencsak megengedő szabályozása), hogy bizonyos kérdésekben kifejezetten a korábbi jugoszláv helyzettel való éles különbségtétel érdekében történt változás (Jelusic 2002, 112-113). A szlovén állami függetlenség elnyerését követő időszakot a civil-katonai kapcsolatok szempontjából egyfajta "kétarcúság" jellemezte. Egyfelől az általános demokratizáció folyamatával párhuzamosan a haderő feletti civil és demokratikus kontroll rendszere is kiépült, a hadsereg politikai szerepét - amely a korábbi jugoszláv periódusban jelentősnek mondható volt - teljesen megszüntették, emellett az egypártrendszer megszűnésével eltünt annak intézményes "átpolitizáltsága" is. Részben az államépités befejezetlen voltából, részben pedig a függetlenség és a demokratikus átmenet módjából adódóan a civil-katonai kapcsolatok területén új problémák is jelentkeztek (Bebler 1996, 201202, 210). Mint Anton Bebler megjegyzi, a többpártrendszer és a demokratikus viszonyok kiépítésére, illetve a hadsereg depolitizálására és a haderő feletti demokratikus kontroll megteremtésére irányuló folyamatok nem mindig egymást erösítették (Bebler 1996, 210, Bebler 2002, 159).

A vizsgált időszakot meghatározta a Janez Janša védelmi miniszter és Milan Kučan államfő közötti politikai vita, melynek gyökerei a függetlenség illetőleg a rendszerváltás előttre is visszanyúltak. Noha ez esetben két civil politikai vezető konfliktusáról volt szó, ez a civil-katonai kapcsolatokra is jelentős hatást gyakorolt, ugyanis több esetben a hadsereg egyes vezető személyiségei is részesévé váltak ezen szembenállásnak (Malesic 2006, 131-132). A vita, mely csak egy részét képezte a Kučan és Janša közötti politikai ellentétnek, jogi-hatásköri kérdésekre irányult (bővebben lásd a 6.2.2. alfejezetben), és több, a témám szempontjából releváns lényegi, vagy szimbolikus politikai lépésben is megmutatkozott. A védelmi miniszter több alkalommal megtagadta az államfö tájékoztatását védelmi kérdésekröl, az államfö megkerülésével nevezett ki magas beosztású katonai vezetőket, vagy eredetileg megtiltotta, hogy a hadsereg az államfö számára díszőrséget biztosítson (Malesic 2006, 134-136). A hatásköri viták azonban nem korlátozódtak az államfó és a védelmi miniszter közötti szembenállásra: folyamatos volt a rivalizálás a Janša 
irányítása alatt álló katonai hírszerzés (VOMO) és a belügyminisztériumhoz tartozó polgári nemzetbiztonsági szolgálatok között is, ráadásul az első években a VOMO parlamenti felügyelete sem volt jogilag megoldott (Szilágyi 2002, 63-64).

Noha az ország kimaradt az 1991 nyarát követően kibontakozó délszláv konfliktusból, a szomszédságukban zajló háború többféle módon hatást gyakorolt a szlovén védelmi szférára is. Legfontosabb tényezőként az 1992-től 1996-ig érvényben volt ENSZ fegyverembargót kell megemlítenem, mely Szlovéniára is vonatkozott. A szlovén hadsereg az embargó hatályon kívül helyezéséig így csak annak megkerülése vagy megsértése útján tudott saját célra fegyvereket vásárolni, a 90-es évek szlovén politikai botrányai pedig jórészt a fegyverembargóhoz és különösen a Horvátországnak, valamint Bosznia-Hercegovinának, Szlovénián keresztül történő illegális fegyverszállításokhoz kapcsolódtak (Szilágyi 2002, 63). Az egyik legkiterjedtebb fegyvercsempészési botrány 1993 júliusában pattant ki, amikor a maribori repülőtéren nagy mennyiségü, a boszniai muszlimoknak szánt kézi- és könnyüfegyverre bukkantak, melyet egy meg nem nevezett közel-keleti országból kívántak volna Szlovénián keresztül, humanitárius segélynek álcázva a háborúban álló balkáni államba csempészni (Szilágyi 2002, 63-64, Bebler 1996, 208, Reuters 1993).

Azonban Janez Janša 1994 márciusi menesztéséhez végül az ún. MORIS-ügy vagy Depala Vas-ügy vezetett, mely alapvetően a haderő feletti demokratikus kontroll kérdéséhez kapcsolódott. A MORIS a szlovén hadsereg különleges műveleti egysége volt, melynek elődjét még 1990 őszén, a Területvédelmi Erők átszervezésének keretében állították fel. Az egység hivatalosan a Területvédelem (1994-től Szlovén Hadsereg) 1. dandárjának alárendeltségébe tartozott. Az 1992 és 1994 közötti időszakban ugyanakkor rendszeresen sor került arra, hogy a védelmi miniszter a hadsereg formális parancsnoki láncát megkerülve, közvetlenül utasította a MORIS katonáit, számos esetben egyenesen jogellenes feladatok elvégzésére. Ebben segítségére volt, hogy a MORIS több vezető beosztású tisztjét a függetlenségi mozgalomra visszanyúló személyes kapcsolatok füzték Jansához, illetve többen a védelmi miniszternek köszönhetően kerültek pozíciójukba (Bebler 1996, 207). A belügyi nyomozó hivatal egy később nyilvánosságra került belső jelentése alapján a védelmi minisztérium számos alkalmazottjával (nem csak a MORIS alárendeltségébe tartozókkal) szemben merült fel egyebek mellett a törvénytelen titkos információgyüjtés, a civil gépjárművek engedély nélküli megállítása és átkutatása, 
valamint a bírói engedély nélküli törvénytelen házkutatás alapos gyanúja (Bebler 1996, 206). A MORIS-hoz és a védelmi tárca más szervezeti egységeihez köthető jogellenes tevékenység gyanúja miatt folytatott nyomozásban vett részt a korábban a Területvédelemnél szolgáló Milan Smolnikar, is akit 1994. márciusában a MORIS és a katonai rendőrség emberei Ljubljana közelében letartóztattak és megvertek. A védelmi minisztérium és a katonai rendőrség az eset kapcsán arra hivatkozott, hogy Smolnikar a HM-től szerzett jogellenesen titkos információkat és letartóztatására nemzetbiztonsági okokból volt szükség (a férfi megverésére vonatkozó vádakat mindvégig tagadták). Smolnikar a katonai rendőrség által lefoglalt gépjármüvében állításuk szerint a védelmi minisztériumtól származó bizalmas dokumentumokat találtak, azonban később sem sikerült megnyugtatóan kizárni azt a lehetőséget, hogy az iratokat utólag helyezték el (Szilágyi 2002, 70-71, Malesic 2006, 136-138). A szlovén BM álláspontja alapján azért kényszerültek titkosszolgálati eszközök alkalmazására a VM-el és a MORIS-al kapcsolatos nyomozásokban, mert a Janša vezette tárca megtagadta a belügyi szervekkel való együttmüködést (Malesic 2006, 137-138). Az eset miatt kirobbanó politikai botrány hamarosan túlnőtt a konkrét esettel kapcsolatos jogsértéseken (így például a katonai rendőrség joghatóságának hiánya civil személyek felett, vagy a Smolnikar megverésével kapcsolatos vádak), és általánosságban a VM-hez köthető visszaélések, Janša jogellenes döntései (így a hadsereg parancsnoki láncának folytatólagos megkerülése), vagy a szlovén VM és BM közötti rivalizálás került a viták fókuszába. A botrány ezen túlmenően azonban a haderő feletti demokratikus kontroll, valamint általánosságban a jogállamiság kérdéseit is érintette. Miután a védelmi miniszter nyilvánosan elismerte, hogy tudott a MORIS akciójáról (amiről azonban írásos parancs soha nem került elö), de megtagadta az abban érintettek felfüggesztését, nemcsak az ellenzék és a közvélemény, hanem a kormánykoalícióban részt vevő pártok is egyre nagyobb nyomást helyeztek Janša-ra távozása érdekében. Lemondása azonban nem önkéntes volt, hanem 1994. március 20.-án a parlament döntött a miniszteri pozícióból való menesztéséről. Az eseményeket a volt miniszter úgy értelmezte, hogy a Milan Kučan államfő körül csoportosuló posztkommunista informális hálózatok folytatnak ellene „boszorkányüldözést”, az államfőhöz és a miniszterelnökhöz közel álló sajtóorgánumok pedig Janša-t vádolták azzal, hogy cselekedeteivel a demokratikus államrendet kérdőjelezte meg, valamint, hogy azokat végső soron törvényellenes hatalomátvételi szándék motiválta (Szilágyi 2002, 70-71, Malesic 2006, 139-140). 
Az 1991 és 1994 közötti, a védelmi- és katonapolitikára vonatkozó éles politikai viták és botrányok hozzájárultak ahhoz, hogy ez a terület erősen átpolitizálódott, mely megnehezítette az intézményépítést, illetve az évtized második felében a politikai elit által célul kitüzött NATO-csatlakozáshoz szükséges politikai és szervezeti reformok bevezetését a honvédelem területén. A MORIS-ügyhöz hasonló botrányok az euroatlanti integrációs szervezeteknek (NATO, WEU) is rossz üzenetet küldtek, mégpedig pont abban az időszakban amikor a politikai elit elkötelezte magát az ezekhez való csatlakozási szándék mellett (Malesic 2006, 143).

\subsubsection{Jogi-intézményi és szervezeti változások}

A jogi környezet szempontjából legfontosabb jelentősége az 1991 decemberében elfogadott új szlovén alkotmánynak volt. Az alkotmány szerint az államfö a fegyveres erők föparancsnoka, de békeidőben ez nem jár konkrét irányítási jogkörrel. A legfontosabb döntési jogköröket az alkotmány a védelmi miniszterhez telepítette, azonban az új honvédelmi törvény 1994-es elfogadásáig a hatáskörök pontos elhatárolásának hiánya számos politikai vitához vezetett (Vankovska és Wiberg 2003, 176-177). Az új alkotmány a parlamentáris rendszerekben szokásos módon rögzítette a törvényhozásnak a fegyveres erők feletti felügyeleti jogát, az alkotmány 92. Cikke szerint a fegyveres erök bevetéséröl való döntés a parlament hatásköre. A fegyveres erök parlamenti felügyeletében a parlament illetékes bizottságai is részt vesznek, valamint a törvényhozás hatáskörébe tartozik a védelmi költségvetés elfogadása az állami költségvetés részeként. Ez jelentős változást jelentett a korábbi jugoszláv gyakorlathoz képest ${ }^{11}$ (Ustava Republike Slovenije 1991, Gow és Carmichael 2000, 136-138). A parlament és a (civil) védelmi miniszter ${ }^{12}$ személyén keresztül megvalósuló civil és demokratikus kontroll bevezetésén túlmenően a demokratikus változásokkal összhangban további jelentős változásokra került sor a civil-katonai kapcsolatok és a haderö társadalmi szerepe területén. Ide sorolható a lelkiismereti szolgálatmegtagadás széles körü engedélyezése, a kötelező sorkatonai szolgálat időtartamának jelentős (7 hónapra történő) csökkentése, a vallásgyakorlók elleni

\footnotetext{
${ }^{11}$ A jugoszláv időszakban a parlament szerepe a védelmi költségvetés elfogadásában csak formális volt (Bebler 2000, 145).

${ }^{12}$ Ebben a fejezetben a minisztériumra (Ministrstvo za obrambo $R S$ ) következetesen a "védelmi minisztérium" (VM), illetve „védelmi miniszter” elnevezést fogom alkalmazni. Egyéb kontextusban, mint például „honvédelmi törvény”, „,honvédelmi bizottság”, ugyanakkor használni fogom a magyar terminológiában használatos „honvédelem” kifejezést is.
} 
diszkrimináció megszüntetése a hadseregen belül, a katonatiszti pálya megnyitása a nők számára, a katonai igazságszolgáltatás jogkörének drasztikus korlátozása (külön katonai bíróságok megszüntetése), a fegyveres erők depolitizálása és a pártpolitikától semlegessé tétele. Lényeges továbbá a hadsereg belbiztonsági szerepkörének teljes megszüntetése is (Bebler 1996, 201-202). Helyi szinten gyakran volt vitatott, és adott okot esetenként visszaélésekre is a korábbi JNH tulajdon (laktanyák, szolgálati lakások, ipari ingatlanok stb.) további sorsa (Bebler 1996, 203). Mint már említettem, korábbi társadalmi igényt elégített ki a lelkiismereti szolgálatmegtagadás liberalizálása is, ugyanakkor a függetlenség előtti időszakhoz képest jelentősen csökkent a joggal élök száma. Bebler ezt a jelenséget arra vezeti vissza, hogy a jugoszláv időszakban a lelkiismereti szolgálatmegtagadás, vagy annak igénye részben a JNH-val - és nem általában a katonai szolgálattal - szembeni, pacifista köntösbe öltöztetett állampolgári ellenállás egy formája volt (Bebler 1996, 205). Hasonló véleményen van Vankovska és Wiberg is, akik úgy fogalmaznak, hogy sokak számára a „demilitarizált Szlovénia” csupán egy olyan elvi elképzelés volt, ami a JNH társadalmi és politikai szerepére adott reakcióként született, mintsem egy konkrét, megvalósítandó politikai program (Vankovska és Wiberg 2003, 170).

A Milan Kučan és Janaez Janša közötti, már említett hatásköri vita az erre az időszakra jellemző tisztázatlan jogi környezetre is visszavezethető volt. Az 1991-es alkotmány, mint korábban már említettem, a fegyveres erők föparancsnokaként az államfőt jelölte meg, noha békeidőben ez a szerep szimbolikus volt, és a tényleges döntési kompetenciákat a védelmi miniszterhez telepítette. 1994-ig ugyanakkor a függetlenség előtt elfogadott 1991-es honvédelmi törvény volt érvényben, mely szerint a fegyveres erők föparancsnoka a köztársaság elnöksége, mely kinevezi a Területvédelmi Erök parancsnokát és vezérkari főnökét a köztársasági védelmi titkár (védelmi miniszter) egyetértésével. Az új alkotmány megszüntette a kollektív államelnökség intézményét, a köztársasági védelmi titkár pozícióját pedig a védelmi miniszterére változtatta, azonban a honvédelmi törvény megfelelő módosítása, különösen az elnökség intézményét illetően nem történt meg. A vita jogi értelemben tehát arról folyt, hogy "örökli"-e az 1992-ben megválasztott államfő a korábbi törvényben a kollektív államfői testületet megillető jogköröket. Ezt a kérdést véglegesen csak az 1994-es honvédelmi törvény elfogadása rendezte (Malesic 2006, 133-135, Bebler 2002, 168-169). 
A honvédelmi ügyekkel kapcsolatos, korábban már ismertetett éles politikai viták részben magyarázzák azt a tényt, hogy a nemzeti biztonsági alapelveket csak 1993 decemberében, míg a független Szlovénia első honvédelmi törvényét csak 1994 decemberében fogadta el a parlament. Az első, jelentős szakmai és politikai kritikákat kapott katonai doktrína elfogadásáig pedig 1995 júliusáig kellett várni (Szilágyi 2002, 67-68, 71-73). A hosszú vita után 1993. december 20.-án elfogadott nemzetbiztonsági alapelvek volt az első jelentős hivatalos dokumentum, ahol a Területvédelmi Erők helyett már a „Szlovén Hadsereg” megnevezés szerepelt (a szlovén haderő hivatalosan csak 1994-ben vette fel ezt a nevet). A dokumentum többszintü biztonságfogalomra épül: noha elismeri, hogy a balkáni válsággóc közelsége jelentős hatással van az ország biztonságára, számos nem katonai fenyegetést is azonosít, így például a terrorizmus, a szervezett bünözés, a tömeges illegális migráció vagy a határokon is átnyúló környezetvédelmi problémák. Az Alapelvek első verziója a NATO-t szó szerint nem említette, az atlanti szövetséggel való együttmüködés szándéka egy néhány hónappal későbbi kiegészítéssel került be annak szövegébe, azonban az eredeti dokumentum vonatkozó passzusait is alapvetően a korábban jellemző semlegességi irányvonaltól való eltávolodás jellemezte. Sajátos jellemzője az 1993-as dokumentumnak, hogy a biztonság és védelmi szférát illető intézményi kérdésekkel is foglalkozik: a parlament, a kormány és a köztársasági elnök vonatkozó feladatainak és hatáskörei mellett először tartalmazza a Nemzetbiztonsági Tanács intézményére való utalást. Érdemes megemlíteni, hogy az említett tanács ténylegesen viszont csak 1998-ban kezdte meg müködését (Szilágyi 2002, 67-70, 75).

A honvédelmi törvényröl folytatott viták részben a már említett Kučan-Janša konfliktushoz kapcsolódtak, de több tekintetben túl is mutattak azon. A vita fö tárgyát a köztársasági elnök és a védelmi miniszter hatásköreinek lehatárolása, valamint az alkotmány szerint leginkább szimbolikus jogköröket élvező államfő békeidőben kifejtendő feladatai (így a kinevezési jogkörök vagy az államfő számára kötelezően átadandó katonai tárgyú információk) jelentették. Milan Kučan köztársasági elnök szerette volna az ezen a területen meglévő feladat- és hatáskörei növelését elérni, azonban ezt a törekvést nem csak Janša ellenezte (Szilágyi 2002, 64). A hosszú viták után végül 1994 december végén megszületett honvédelmi törvény a hatáskörök kitágítására irányuló elnöki törekvések kudarcát jelentette. Az új törvény szerint például a vezérkari főnök kinevezése a védelmi miniszter javaslata 
alapján a kormány feladata - Kučan azt szerette volna, ha a vezérkari főnököt a köztársasági elnök nevezné ki és neki is tartozna felelősséggel -, valamint a védelmi miniszter az elnök egyetértésével maga határozhatja meg, milyen módon és formában biztosítja az államfőnek a fegyveres erők harckészültségéről szóló és egyéb olyan információkat, melyek békeidőben föparancsnoki jogköre kifejtéséhez szükségesek. Az új törvény részletesen szabályozza az országgyülés feladatköreit a fegyveres erők demokratikus kontrolljában és rendelkezik a katonai nemzetbiztonsági szolgálatok parlamenti kontrolljáról is ${ }^{13}$ (Szilágyi 2002, 64-65, 7172). Noha az elfogadott új jogszabályok a nemzetközi gyakorlattal összhangban teremtették meg a fegyveres erők parlamenti felügyeletének rendszerét, a gyakorlatban ennek müködése kevéssé volt kielégítő. Ennek egyik oka az információhiány (mely kapcsolatba hozható a fegyveres erők gyakorlatilag újonnan létrehozott volta és a jelentős „kádercsere” ellenére tovább élő, az előző rendszerhez köthető „titkolózási” kultúrához), másik pedig a parlamenti képviselők kompetenciahiánya, valamint az őket támogató parlamenti háttérintézmények kialakulatlansága volt (Bebler 1996, 210, Malesic és Jelusic 2005, 216). A korábbi pacifista politikai irányzatok ugyan az 1991-es háborút követően jelentősen meggyengültek, de a társadalom hadsereggel és katonai kérdésekkel kapcsolatos szkepticizmusa nem tünt el teljesen, melyet az ebben az időszakban zajló, a kívánatos katonai költségvetés nagyságával kapcsolatos viták is jeleztek. Az ellenzéki pártok és a média egy része (közöttük a védelmi miniszter egykori munkáltatója, az immáron vele szembenálló Mladina hetilap) sokallta az új kormányzat által honvédelemre fordítandó összeget, Janša és munkatársai viszont azt hangsúlyozták, hogy a korábbi Jugoszlávián belüli értékhez képest a független Szlovénia egyharmad vagy egynegyed akkora összeget fordít a haderöre (Vankovska és Wiberg 2003, 180, Szilágyi 2002, 65-66). A nagymértékü védelmi kiadáscsökkenést Anton Bebler adatai is alátámasztják: míg az utolsó teljes „jugoszláv” évben, 1990-ben Szlovénia átszámítva 900 millió dollárt fordított a JNH fenntartására, a független államiság első három évében az új szlovén haderő kiadásai 200 (1992), 165 (1993), illetve 190 (1994) millió dollárt tettek ki (Bebler 1996, 200).

13 Mint láttuk ennek hiánya a kilencvenes évek elején több jogsértő cselekményre teremtett lehetőséget. 


\subsubsection{A védelmi szféra nemzetközi dimenziója}

Mint a jelen alfejezet elején már említettem, a korszakot egyfajta „útkeresés” jellemezte a biztonság- és védelempolitikai külső orientáció terén is. A függetlenné válást közvetlenül követő időszakban a fegyveres semlegesség koncepciója volt jellemző, ez azonban nem jelentette az egykori Jugoszláviához hasonló el nem kötelezettséget. A 80-as, 90-es évek fordulóján népszerü demilitarizációs elképzelések fokozatosan háttérbe szorultak (Jelusic 2002, 112). A szlovén államelnökség 1991 novemberében fogadta el az első biztonság- és védelempolitikai alapelveket, mely ekkor (részben kényszerüségböl) még a defenzív semlegesség elvét fogalmazta meg. A dokumentum szerint az ország fegyveres támadás esetén potenciálisan más államokkal kötött szövetségre, ill. létrejötte esetén egy összeurópai kollektív biztonsági rendszerre is támaszkodna (Bebler 1993b, 67). Ez utóbbi megfogalmazás egyértelműen egy ilyen összeurópai biztonsági architektúra létrejöttével kapcsolatos 90-es évek eleji optimizmust tükrözi.

Noha egyes politikusok, így például Janez Janša védelmi miniszter már 1992-ben szorgalmazták a NATO-hoz való közeledést, ezt ebben az időszakban nemcsak a szlovén politikai elit nagyobb része nem tartotta reálisnak, maga az atlanti szövetség sem mutatkozott hajlandónak a „laza” intézményes kapcsolatok létesítésére sem. Az első hivatalos, a NATO fötitkáránál tett magas szintü szlovén látogatásra 1993 márciusában került sor, Manfred Wörner főtitkárral Janez Drnovsek miniszterelnök és Janez Janša védelmi miniszter folytatott megbeszéléseket (Szilágyi 2002, 65-66). Ebben az időszakban még nem volt tisztázott, hogy az intézményes együttmüködés milyen formája alakítható ki, valamint a szlovén társadalom és politikai elit véleménye sem volt egyöntetü a NATO-hoz való közeledést illetően. Szlovén biztonságpolitikai szakértők, így például Anton Bebler és Teodor Gersak ebben az időszakban úgy vélték, hogy az ország reálisan a kétezres évek első évtizedének közepén nyerhetne felvételt az atlanti szövetségbe (Lásd Gersak 1995, 70 és Szilágyi 2002, 67).

Mint említettem, a nemzeti biztonsági alapelvek elfogadásával a szlovén kormányzat elmozdult a semlegesség korábbi álláspontjáról, a dokumentum 1994 elején történő kiegészítésével pedig egyértelmüen a NATO orientáció mellett kötelezte el magát. Erre már egy korábbi 1993 novemberi országgyülési határozat is utalt, amely a NATO és WEU társult tagság elérését tüzte ki célul. Az ország 1994 márciusában 
csatlakozott a Partnerség a békéért (Partnership for Peace, PfP) programhoz, 1994 novemberében pedig az Észak-atlanti Közgyülés (ma NATO Parlamenti Közgyülés) társult tagja lett (Szilágyi 2002, 62, 65-70).

\subsubsection{A magyarázó tényezők hatásának értékelése}

A történelmi örökség hatása a szlovén független államiság első szakaszában részben olyan intézkedésekben jelentkezett, melyek a korábbi jugoszláv gyakorlattal való éles különbségtételt voltak hivatottak érzékeltetni, mint például a lelkiismereti szolgálatmegtagadás európai viszonylatban is megengedő szabályozása. A jugoszláv történelmi örökség részét képezte azonban az is, hogy az önálló szlovén haderő a korábbi Területvédelem bázisán jött létre, mely pedig sokkal inkább egy milícia jellegü erő volt, nem pedig egy modern hadsereg (Kopac 2017). A Területvédelem ilyen formájú „intézményi öröksége”, párosulva a hadsereg tisztikarának heterogén összetételével (korábbi TV és JNH tisztek jelenléte a szlovén hadsereg tiszti és fötiszti állományában), és az 1991-es háború tapasztalataival a kilencvenes évek során több ponton hatást gyakoroltak a szlovén haderő fejlődésére és a civil-katonai kapcsolatokra is (Malesic és Jelusic 2005, 211-212, Jelusic 2017, Kopac 2017).

Mivel Szlovénia a tíznapos háborút leszámítva kimaradt a délszláv konfliktusból, a fenyegetés-percepiók hatása csak korlátozottan jelentkezett. Mivel a horvátországi háború közvetelnül az ország szomszédságában zajlott, egyfajta „izraelizáció” (Vankovska 1995, 219-220) volt megfigyelhető a szlovén társadalomban ebben az időszakban. A délszláv háborúk következménye volt ugyanakkor az ENSZ fegyverembargója is, mely ugyanakkor Szlovéniára is vonatkozott.

Ebben a periódusban egyértelmüen a belső politikai folyamatok gyakoroltak meghatározó hatást a szlovéniai civil-katonai kapcsolatokra. A védelmi miniszter és a köztársasági elnök közötti, részben jogi-hatásköri, részben pedig politikai jellegü viták, illetve a hadsereg bizonyos tisztjeinek ezen vitákban való részvétele vagy „bevonása” egyértelmüen negatívan hatott a demokratikus civil-katonai kapcsolatok kialakulására (Malesic 2006, 131-132, 143). A kilencvenes évek eleji szlovéniai események fő tanulsága, hogy a hadsereg feletti civil és demokratikus kontroll még nem jelenti automatikusan a hadsereg politikai semlegességét. Kialakulatlan jogi és intézményi környezet, valamint éles belpolitikai ellentétek esetén könnyen előfordulhat a fegyveres erők átpolitizálódása, vagy politikusok általi, pártpolitikai 
célokra történő felhasználása (Bebler 1996, 209-210). A kilencvenes évek eleji Szlovéniában a problémát ez jelentette, és nem a hadsereg politikai befolyása (a pretorianizmus), amitől az átalakuló országokat illetően a külföldi megfigyelők ekkoriban tartottak (ld. pl. Herspring 1992).

A nemzetközi szereplök hatása a szlovéniai civil-katonai kapcsolatokra ebben a periódusban korlátozottnak tekinthető. A NATO hatásáról nem beszélhetünk, mivel viszonylag későn (1993-1994 fordulóján) alakult ki a politikai eliten belüli konszenzus a biztonságpolitikai orientációról, illetve a NATO-val való első intézményes kapcsolatfelvételre csak az időszak vége felé, 1993-ban került sor.

Ennél némileg jelentősebb volt a Szlovéniára is érvényes ENSZ-fegyverembargó hatása, mely egyfelől befolyásolta a szlovén hadsereg képességfejlesztését, másfelől pedig, mint említettem esetenként politikai botrányok előidézőjévé vált, mint például a maribori repülőtéren lefoglalt, Boszniába szánt fegyverszállítmány esetében (Kopac 2017, Szilágyi 2002, 63-64).

\subsection{A korai NATO tagság illúziója (1994-2000)}

\subsection{1. Általános politikai trendek}

Az általam vizsgált második időszak fő meghatározó tényezői közül két fontos elemet lehet kiemelni: az első a külső biztonsági fenyegetések háttérbe szorulása a horvátországi és boszniai háború végeztével, a második pedig az elit szintjén megszületett konszenzus, mely szerint az ország biztonságát a NATO-hoz való csatlakozás útján szeretnék garantálni. Annak ellenére, hogy a korábban említett „biztonságpolitikai útkeresés” immáron lezárult, a szlovén politikai elit, 1997-ig legalábbis mindenképp, leginkább csak bízott abban, hogy az ország mindenképp bekerül a NATO kibővítésének első körébe. Ezt leginkább a csatlakozás politikai követelményeinek (demokrácia, működő piacgazdaság) teljesítésére, valamint arra alapozták, hogy az ország nem volt a Varsói Szerződés tagja, ezért Oroszország számára sem jelenthet problémát a NATO-ba történő belépése (lásd pl. Grizold 1997c, 91-101, Bebler 1999, 49-57).

A haderő reformja és NATO-kompatibilissé tétele terén, különösen 1997-ig megmutatkozó elmaradások azonban az egyik, a helyi elemzők és megfigyelők által akkor nem kellően felismert okát képezték annak, hogy Szlovénia nem kapott 
meghívást az atlanti szövetség kibővítésének 1999-es, első körébe (Szilágyi 2002, 81-83). Lényeges megemlíteni, hogy a NATO-tagság kérdésében a közvélemény sem volt egységes: a szlovén társadalom egy része kifejezetten ellenezte a NATOcsatlakozást, míg egy további csoport a NATO-tagság egyes konkrét aspektusaival mint például a szlovén katonák külföldi missziókon való bevetése vagy a Szlovéniában esetlegesen létesítendő NATO bázisok - kapcsolatban volt elutasító (Szilágyi 2002, 79-81). Kotnik és Kopac (2002, 149-151) értékelése alapján ezen időszak fő belső problémái közé tartozott a politikai akarat hiánya a hadsereg átfogó reformjára és professzionálissá tételére, az átlátható katonai előléptetési- és életpályamodell hiánya, a forrásszükösség és a rendelkezésre álló források nem hatékony felhasználása, valamint a fegyveres erők ,átpolitizálása” a politikai vezetés által. További problémát jelentett a reformszemléletű katonai vezetők szinte teljes hiánya, a sorkatonaság intézményének válságba kerülése a 90-es évek végére, valamint a közvélemény növekvő mértékü érdektelensége a honvédelmi ügyek iránt. Általánosságban jellemző volt a vizsgált időszakra az a tendencia, melyet Arnejcic és Vuk a felhalmozódott problémák gyors és ad hoc megoldásokkal való kezelésének nevezett. Ezen gyorsan bevezetendő megoldások nélkülözték mind a stratégiai gondolkodást, mind pedig az érintett probléma komplex megközelítését, beleértve a hatástanulmányok elkészítését is (Arnejcic és Vuk 2001, 185 illetve Barany 2003, 113-114). Hasonlóképpen vélekedik Kotnik és Kopac is, mint a két szerző fogalmaz, több esetben elöfordult, hogy a stratégia-alkotás helyett a kormányzati stratégiai dokumentumokat igazították a létező helyzethez (Kotnik-Dvojmoc és Kopac 2002, 150-151). Milan Jazbec (2003, 193-194) ezt az időszakot értékelve egymást követő, félbehagyott reformokról és reformkísérletekröl ír. Amellett, hogy a vizsgált időszakban a politikai elit nem rendelkezett kidolgozott elképzeléssel a haderő modernizációját illetően, a hadsereg felső vezetéséből is sokáig hiányzott az a reformszemléletű fötiszti kör, mely a védelmi átalakítások végrehajtásában részt vállalhatott volna. (Kotnik és Kopac 2002, 160-161). A helyzet fennmaradásához hozzájárult a meritokratikus alapokon nyugvó elöléptetési és életpályamodell hiánya is: a tiszti pályán való előmenetelhez sok esetben nagyobb súllyal estek latba a politikai és személyes kapcsolatok, mint a katonai szakmai rátermettség és felkészültség. Az objektív mérési és teljesítmény-értékelési rendszer bevezetése a vizsgált időszakban sem a hadsereg hivatásos állományú tagjainál, sem pedig a védelmi minisztérium tisztviselöinél nem került bevezetésre, melyben az érintettek 
ellenérdekeltsége is szerepet játszott (Kotnik és Kopac 2002, 156).

Az 1994-et követő időszakot a területvédelmi, milícia jellegü haderő koncepciójától való elmozdulás jellemezte, azonban több tekintetben (struktúra, föbb missziók, fejlesztendő képességek, sorozott és hivatásos állomány pontos aránya) nem született politikai konszenzus arról, hogy milyen legyen az új, immár a NATO-csatlakozás célkitüzését is figyelembe véve kialakított szlovén haderő (Kopac 2017, Svete 2011, Szilágyi 2002, 88-90). Keridis és Perry megfogalmazása szerint egyfajta „versengés” volt megfigyelhető a svájci mintára épülő milícia-szerü területvédelmi koncepció, és a gyorsan mozgósítható, hivatásos, nemzetközi és NATO feladatokra is felkészített haderő modellje között (Keridis és Perry 2004, 9). Megítélésem szerint ennek a szakmai vitának, az utóbbi modell ,javára” az időszak végén, legkésőbb pedig a 2000 novemberében hivatalba lépett Anton Grizold miniszter hivatali ideje alatt elindított reformokkal került pont a végére. (Ld. pl. RS Ministry of Defense 2009b, 9).

A világos és következetes szakpolitika-formálást ezen a területen az is nehezítette, hogy 1994 márciusa és 2000 novembere között összesen 6 honvédelmi miniszter váltotta egymást, miközben választásokat ebben az időszakban csak egy alkalommal tartottak (Jelusic 2002, 118-119).

\section{5. táblázat: Honvédelmi miniszterek Szlovéniában 1994 és 2000 között.}

\begin{tabular}{|l|l|l|}
\hline Miniszter (párt) & Miniszterelnök (párt) & Hivatali időszak \\
\hline Jelko Kacin (LDS) & Janez Drnovsek (LDS) & $1994.03 .29-1997.02 .27$ \\
\hline Tit Turnsek (SLS) & Janez Drnovsek (LDS)* & $1997.02 .27-1998.03 .13$. \\
\hline Alojz Krapez (SLS) & Janez Drnovsek (LDS) & $1998.03 .13-1998.11 .24$ \\
\hline Lojze Marincek (SLS)** & Janez Drnovsek (LDS) & $1998.11 .24-1999.02 .04$ \\
\hline Franci Demsar (SLS) & Janez Drnovsek (LDS) & $1999.02 .04-2000.06 .07$. \\
\hline Janez Janša (SDS) & Andrej Bajuk (NSi) & $2000.06 .07-2000.11 .30$. \\
\hline
\end{tabular}

*: Az 1996-os választásokat követően alakult új kormány

**: ügyvezető miniszter

Rövidítések feloldása: LDS: Szlovénia Liberális Demokráciája / Liberális Demokrata Párt, SLS:

Szlovén Néppárt, SDS: Szlovén Szociáldemokrata Párt, NSi: Új Szlovénia - Kereszténydemokrata Néppárt

Forrás: saját szerkesztés a http://www.vlada.si és a http://mo.gov.si adatai alapján

A gyakori miniszterváltások megnehezítették a szakpolitikai folytonosság kialakulását ezen a területen, különösen mivel az új tárcavezetők általában saját védelem- és katonapolitikai koncepciójukat igyekeztek megvalósítani, illetve miniszterváltások általában nagy arányú minisztériumi személycserékkel is jártak (Malesic 2017, Vankovska és Wiberg 2003, 177-178, Jazbec 2003, 193-194). 
Jelko Kacin miniszteri időszakát a tárcavezető és a Janša-érában pozícióba került minisztériumi vezetők közötti viták jellemezték, a minisztert pedig politikai támadások is érték, 1995-ben például a szlovén parlamentben sikertelen interpellációt kíséreltek meg elmozdítására (Gow és Carmichael 2000, 188). Kacin utódja, Tit Turnsek pedig egy év után, 1998 tavaszán mondott le a szlovén katonai hírszerzés két ügynökének horvátországi letartóztatása miatt kialakult botrány következtében (Jelusic 2017, Gow és Carmichael 2000, 189).

A Turnseket követő Alojz Krapez csak néhány hónapot töltött a minisztérium élén, amikor egy korrupciós ügy miatt távozásra kényszerült, emiatt gyakorlatilag nem volt lehetősége az érdemi politikaformálásra. Érdemes megemlíteni, hogy az említett ügy egy, a szlovén Védelmi Minisztérium birtokában lévő lakással volt kapcsolatban, melynek a miniszter a vádak szerint jogellenesen szerezte meg a használati jogát (Jelusic 2017, RFE/RL 1998). Lojze Marincek, a tudományos és technológiai tárca birtokosa pedig eleve csak ideiglenesen, ügyvezetö miniszterként vezette rövid ideig a védelmi tárcát is (Gow and Carmichael 2000, 171-172, Szilágyi 2002, 89). Ezen túlmenően az a tény, hogy az 1996-os választást követően a kormányalakítás hat hónapot vett igénybe, az ország számára kritikus 1997-es madridi NATO csúcsértekezlet előtt kevesebb mint egy évvel vezetett a politikai döntéshozatal hosszabb időre történő „leállásához” (Bebler 1999b, 154).

A Janez Drnovsek vezette kormány 2000 nyári bukása és a rövid életű (2000 júniusnovember) Andrej Bajuk vezette jobbközép kabinet hivatalba lépése a védelempolitika területén is újabb változásokat jelentett. Az újra védelmi miniszteri szerepet vállaló Janez Janša számos kritikát fogalmazott meg az előző kormányzatok védelempolitikájával szemben. Az új tárcavezető bírálta, hogy a haderő fejlesztésére szánt források nagyobb részét a légierőre fordították, míg a legelavultabb felszereléssel rendelkező gyalogság a források legkisebb részét kapta, illetve, hogy korábban nem megfelelően használták fel a tankok modernizálására költött összegeket. Janša azt is hibásnak tartotta, hogy a haderő hosszú távú fejlesztéséről szóló programot (lásd alább) a Nemzeti Biztonsági Stratégia kidolgozását megelőzően fogadták el (Svete 2011, Szilágyi 2002, 89-90, Bric 2000, idézi Szilágyi 2002, 90). A kilencvenes évek második felében kezdődött meg a hadkötelezettség eltörléséről szóló szakmai és politikai vita is. A kizárólag hivatásos hadsereg, mint kívánatos végcél egyben a sorozásra épülő jugoszláv modellel való végleges szakítást is jelentette volna, ugyanakkor a döntéshozóknak számolniuk kellett az 
önkéntes haderőre való áttérés jelentős költségeivel is (Malesic 2017, Kotnik és Kopac 2002, 158-159). A hivatásos hadsereg melletti érveket erősítette, hogy a kötelező sorkatonai szolgálat intézménye válságba került a kilencvenes évek második felére: újra jelentős növekedésnek indult a lelkiismereti szolgálatmegtagadók aránya mely 2000-re az összes sorköteles 20\%-át tette ki (Jelusic 2005, 83, Barany 2003, 120).

A parlamentbe jutott politikai pártok szinte mindegyike célul tűzte ki a hivatásos hadseregre való távlati áttérést, különbségek csak annak módjában és ütemezésében voltak (Kotnik és Kopac 2002, 154-155). Noha már a rövid életű Bajuk-kormány hivatali ideje alatt fontolgatták a hivatásos hadseregre történő áttérést, a politikai döntés a sorozás kivezetéséről azonban csak később, 2002 tavaszán született meg (Szilágyi 2002, 89-90, 93).

Anton Bebler (2004, 128) szerint a kilencvenes évek második felében egyes esetekben a „civil-katonai kapcsolatok” helyét a „civil-civil kapcsolatok” vették át, mivel a védelmi rendszer nagymértékben a civil köztisztviselők által dominált volt, és az ekkori katonai vezetők többsége is viszonylag rövid ideje szolgált a szlovén hadsereg kötelékében. A fegyveres erők létrejöttének módja, valamint személyi állományának heterogenitása miatt hiányzik a közös szocializációs háttér és szakmai, testületi kultúra, mindez pedig nem csak egy „katonai lobbi” létrejöttét teszi lehetetlenné, hanem a katonatiszti kar, mint társadalmi csoport igen gyenge érdekérvényesítő képességét is magyarázza (Bebler 2004, 128-130).

\subsubsection{Jogi-intézményi és szervezeti változások}

A független Szlovénia történetének első katonai doktrínáját 1995-ben fogadták el: noha a doktrína célul tüzte ki a NATO-val való kompatibilitást, sok tekintetben továbbra is a területvédelmi szemléletre épült, a konvencionális és a partizán típusú hadviselés elemei is megtalálhatók voltak benne. A doktrínát már megjelenésekor is jelentős kritikák érték: bírálói szerint a dokumentum alapvetően nem szakmai, hanem politikai jellegü, illetve tartalmi felépítését tekintve zavaros volt. Mivel a katonai doktrína elfogadását nem előzte meg a Nemzeti Biztonsági Stratégia és a Nemzeti Katonai Stratégia kidolgozása, annak tartalmában a három stratégiai dokumentumra jellemző elemek keveredtek. További problémát jelentett a kritikusok szerint, hogy a dokumentumból nem derül ki, hogy annak kidolgozói hogyan egyeztetik össze a 
szigorú területvédelmi orientációt a NATO-val való együttmüködés célkitüzésével (Szilágyi 2002, 72-74). Krajnc Zoltán (2009) szerint a deklarált célok fényében a sikeres doktrínaalkotást nehezítette, hogy elfogadásának idején Szlovénia nyugati katonai kapcsolatai korlátozottak voltak, különösen a NATO-n belüli doktrínaadaptáció szempontjából lényeges USA-val és Nagy-Britanniával. Mindezen okok miatt a doktrína felülvizsgálatára irányuló előkészületek annak elfogadását követően nem sokkal megkezdődtek (Szilágyi 2002, 74, Grizold 1997, 52).

A szlovén hadsereg felszerelésének és fegyverzetének elavult és hiányos volta miatt 1994-től a felszerelés- és fegyverzetmodernizáció új forrásaként vezették be az ún. Fejlesztési Alapprogramot. A szlovén Pénzügyminisztérium által kezelt fejlesztési alap a honvédelmi minisztérium forrásain túl biztosított pénzeszközöket a haderő eszközeinek modernizálására, a program első változata szerint 1994 és 2003 közötti időszakra (Keridis és Perry 2004, 12, Barany 2003, 121) A Janša-időszak egyes hatásköri vitáinak elkerülése végett a honvédelmi törvény elöírásain túlmenően 1995-ben egy miniszteri rendelet is szabályozta a honvédelmi miniszternek a köztársasági elnök -mint a hadsereg föparancsnoka- felé fennálló kötelezettségeinek teljesítését. A rendelet az államfó tájékoztatási kötelezettségén, valamint azon kérdések szabályozásán túlmenően, ahol a honvédelmi miniszter az államfő egyetértésével dönt, olyan kérdéseket is érintett, mint a hadsereg felhasználása az államfő személyes védelmére, vagy a köztársasági elnök katonai tanácsadójának jogállása (Arnejcic és Vuk 2001, 186, Ministrstvo za obrambo 1995).

A Nemzeti Katonai Stratégia (hivatalos nevén Strategija vojaske obrambe Republike Slovenije, a Szlovén Köztársaság Katonai Védelmének Stratégiája) elfogadására 1998 májusában került sor. A stratégia célul tüzte ki a szlovén hadsereg NATO interoperabilitási képességének megteremtését 1999 áprilisáig: e téren főként szervezeti, eljárási, logisztikai és nyelvi feladatokat fogalmaz meg. A hadsereg strukturális átalakítását tekintve a dokumentum gyorsreagálású erőket, fő védelmi erőket és kisegítő erőket különböztetett meg. A dokumentum ezen verziója a páncélos képességek modernizálását, emellett korszerü páncélelhárító, légvédelmi és tüzérségi támogatási képességek kialakítását irányozta elő (Szilágyi 2002, 86).

Az államfö és a kormány közötti nézeteltérések miatt a Nemzetbiztonsági Tanácsot csak 1998-ban állították fel. A tanácsadó testület a miniszterelnökön és helyettesén, az igazságügy- miniszteren és a polgári nemzetbiztonsági szolgálat vezetőjén túl négy, védelmi szempontból „stratégiai jelentőségü” minisztérium (külügy, belügy, 
honvédelem, pénzügy) vezetőit tömörítette (Szilágyi 2002, 75).

A politikaformálásban jelentős szerepet a tanács nem játszott, Barany $(2003,111)$ értékelése szerint munkáját ,a dinamizmus és átláthatóság hiánya” jellemezte. Az akkori védelmi miniszter, Franci Demsar (1999-2000) állította fel 1999-ben a minisztérium Stratégiai Tanácsát, melyben elismert, a minisztériumon kívüli biztonság- és védelempolitikai szakértők is helyt kaptak. A tanács részt vett az egyes stratégiai dokumentumok ekkor folyamatban lévő előkészítésében is (Barany 2003, 111, Grizold 2014). Az 1999-es év során került sor két jelentős dokumentum elfogadására, mely a haderő struktúráját és a haderő feletti politikai kontroll kérdését is érintették: a Szlovén Hadsereg fejlesztésének és felszerelésének általános hosszú távú programja (Splosni dolgorocni plan razvoja in opremljanja Slovenske Vojske), illetve a Szlovén Hadsereg létszáma és szerkezete 2010-ben (Obseg in struktura Slovenske Vojske 2010) címet viselő kormányhatározat. (Szilágyi 2002, 86-87, Kotnik-Dvojmoc és Kopac 2002, 151)

A parlament által 2000 februárjával törvénybe iktatott hosszú távú program a témánk szempontjából leglényegesebb megállapítása, hogy a szlovén haderő „továbbra is örzi a Területvédelem néhány sajátosságát, ezért jelenleg nem teljesen hasonlítható össze a nyugati államok vele összemérhető hadseregeivel" (Szilágyi 2002, 87). A haderő struktúrájának átalakításában a program fö feladatok között jelölte meg a parancsnoki struktúra modernizálását, a vezérkar átalakítását, valamint a gyorsreagálású erök felállítását. A koncepció szerint a immár integrált, összhaderőnemi vezérkar a védelmi minisztérium keretében müködne a továbbiakban. Ezen túlmenően a program részletesen tárgyalta az elkövetkező évek szükséges katonai beszerzéseit és a honvédelmi kiadások kívánatos szintjét (Szilágyi 2002, 87). Keridis és Perry $(2004,16)$ szerint pénzügyi aspektusait tekintve a hosszú távú terv (sem eredeti, sem későbbi 2001-ben módosított verziójában) nem felelt meg a modern védelmi költségvetési tervezési és programozási rendszer (planning, programming and budgeting system, PPBS) fogalmának, mivel a hosszú távú terv nem szól a tervezett beszerzések pénzügyi fedezetéről.

A kilencvenes években mindvégig problémát jelentett, hogy a katonai beszerzések nem koherens stratégia keretében történtek, és nem mindig voltak összhangban a tágabb biztonság- és védelempolitikai célokkal, különösen a NATO-kompatibilitás és interoperabilitás tekintetében (Kopac 2017, Keridis és Perry 2004, 16).

Ebben az időszakban több esetben fontosabb katonai beszerzésekröl az éppen 
hivatalban lévő miniszter pillanatnyi elképzelései vagy szempontjai alapján, illetve a védelmi minisztériumon belüli ad hoc koalíciók támogatásával történtek. Így tehát a szakpolitikai folyamatosság hiánya a minisztérium vezetésében ezen a területen is éreztette hatását (Kopac 2017, Malesic 2017).

Grayston $(2001,10)$ stratégiai tervezés hiányára utaló példaként említi a Pilatus típusú kiképző repülőgépek beszerzését, melyek megvásárlását a szerző szerint az a (nem reális) feltételezés motiválta, hogy a szlovén légierő a belátható jövőben harci repülőgépeket is vásárol. Jelusic (2017) szerint azonban a Pilatus-projekt inkább Jelko Kacin miniszterhez és a szlovén légierő kis létszámú, de NATO-párti vezető tisztjeihez volt köthető, mely alapvetően azt a célt szolgálta, hogy a későbbi nemzetközi együttműködés szempontjait is szem előtt tartva javítsa a szlovén katonai pilóták igencsak csekély tapasztalatát.

A képesség-tervezés hiányának további jellemző példája volt a szlovén hadsereg T55 tankjainak a kilencvenes évek végén történt modernizációja. Noha a modernizációs program jelentős forrásokat emésztett fel, ezeket az eszközöket néhány év múlva kivonták a szlovén fegyveres erők hadrendjéből, miután a NATOcsatlakozási folyamat, majd a NATO-tagság keretei között a védelmi politika ezekkel a képességekkel már nem számolt (Kopac 2017).

A hadsereg létszámáról és struktúrájáról szóló határozat egyebek mellett egy három részből álló haderő koncepcióját vázolja fel: a gyorsreagálású erők kizárólag hivatásos állománnyal müködnek, melyet kiegészít a hivatásos és sorállományúakból álló fő védelmi erő és a tartalékos kiegészítő erő. A határozat elfogadásáról döntő 1999 szeptemberi kormányülésen a stratégiai jellegü dokumentumok kérdése is terítékre került: mivel a kormány által megjelölt 10 dokumentumból ezen időpontig csak három készült el, kormányhatározat döntött a további dokumentumok két éves határidőn belüli elfogadásáról (Szilágyi 2002, 88)

Kotnik-Dvojmoc és Kopac $(2002,151)$ szerint azonban a két 1999-es dokumentum által kitüzött célok később irreálisnak bizonyultak, és inkább abba a trendbe illeszkedtek, amelyet a két szerző a retorika és a valóság közötti jelentős eltérésnek nevez. Érdemes megemlíteni, hogy a NATO által ekkor megfogalmazott szakpolitikai kritikák egyike is az volt, hogy a szlovén koncepciójellegü védelmi dokumentumok nem feleltethetők meg a szövetségben használtakkal (Barany 2003, 117).

Összegzésként tehát az 1994-2000 közötti időszak fő jellemzője a szakpolitikai 
folyamatosság hiánya, illetve a prioritások gyakori változása (így például a fejlesztendő, kialakítandó katonai képességek tekintetében), valamint a jelentős távolság a deklaratív célkitüzések és a valós eredmények között, különösen az euroatlanti integráció területén.

\subsubsection{A védelmi szféra nemzetközi dimenziója}

A szlovén haderő nemzetközi szerepvállalásának kezdetei viszonylag későre, a kilencvenes évek második felére tehetők. Ugyan a kizárólag hivatásosokból álló 10. nemzetközi együttmüködési zászlóaljat már 1994-ben, Jelko Kacin minisztersége idején létrehozták, az egység feltöltése érdemben csak évekkel később indult meg, és teljes mértékben csak 2002-ben vált müködőképessé (Jelusic 2017, Jelusic és Malesic 2003, 173, Jelusic 2002, 113-114, Barany 2003, 123). Az ország 19971998-ig nem vállalta a balkáni válságkezelésben való részvételt, ezt részben történelmi, részben politikai és katonai érvekkel indokolták (Bucar és Sterbenc 2002, 126). Szlovéniai elemzők szerint a balkáni válságkezeléssel kapcsolatos „konstruktív távolmaradás" (constructive disengagement) politikájának kevés alternatívája volt a kilencvenes évek első felében és Ljubljana elsődleges prioritása az volt, hogy mindenképpen megelőzze a délszláv konfliktusokba való - újbóli - belesodródást (Idézi Barany 2003, 99).

A Szlovénia és a NATO közötti első formális együttmüködési programot (a Partnerség a Békéért keretében) 1995-ben fogadták el, mely elsődlegesen a szabványosítás, katonai képzés és továbbképzés, valamint jogi-intézményi környezet terén tüzte ki célul a NATO elvárásokhoz való közeledést (Jelusic 2002, 114, Jazbec 2003, 191). Szintén a Békepartnerség keretében került sor 1995 augusztusában az Egyesült Államokban a „Cooperative Nugget 95” hadgyakorlatra, mely az első NATO-hadgyakorlat volt, amin szlovén katonák is részt vettek, 1996 januárjában az ország pedig az Észak-Atlanti Együttműködési Tanács (NACC) tagja lett (Jazbec 2003, 191). Problematikus volt ugyanakkor, hogy a kilencvenes években a kormányok a hadsereg modernizációját és a NATO Békepartnerségben való részvételt, illetve a NATO tagságra való felkészülést alapvetően egy hivatásosokból álló „elit mag” létrehozásával képzelték el, míg a döntő többségben sorozásra épülő szlovén haderő többi részének fejlesztése elmaradt (Kotnik és Kopac 2002, 161). Tekintve, hogy a külföldi missziókban a hadsereg igen kis része vett részt, a NATO- 
ban jellemző korszerü katonai módszereknek és gyakorlatoknak való „kitettség” is alacsony maradt, és alapjában véve kevés hatást gyakorolt a szlovén fegyveres erők egészére (Kotnik és Kopac 2002, 158).

A szlovén hadsereg első nemzetközi béketámogató műveletben való részvételre 1997 tavaszán Albániában került sor az olasz vezetésű, ENSZ-mandátum alatt működő Alba-müvelet keretében (Malesic et al 2015, 163, Keridis és Perry 2004, 33-34). A balkáni válságkezelésben való részvétel kilencvenes évek végétől vált intenzívebbé, Szlovénia egyebek mellett a boszniai SFOR-ban, illetve a koszovói KFOR-ban is szerepet vállalt (Barany 2003, 105, Keridis és Perry 2004, 33-34).

Ebben az időszakban a politikai elit többsége és a szlovéniai szakértők egy része is igencsak optimista volt azt illetően, hogy az ország meghívást kap az atlanti szövetség bővítésének első körébe. Az 1995-ben közzétett első bővítési tanulmány is kedvezően nyilatkozott az országról, valamint Szlovénia a három visegrádi országgal együtt szerepelt az 1996-ban az amerikai kongresszus által elfogadott, a csatlakozásra felkészülő országok támogatását célzó törvényben is (Gow és Carmichael 2000, 198). Hasonló pozitív véleményt fogalmazott meg az országról 1995-ös kelet- és közép-európai körútja során William Perry amerikai védelmi miniszter is (Barany 2003, 100 és 103). A szlovén előzetes várakozásokkal szemben a szervezet 1997-es madridi csúcstalálkozóján azonban csak Magyarországot, Lengyelországot és Csehországot hívták meg a bővítés első körébe.

A NATO általi 1997-es elutasítás okainak kérdése igen jelentős figyelmet kapott a szlovén sajtóban, valamint kül- és biztonságpolitikai szakirodalomban. A korai NATO-csatlakozási ambíciók kudarcát az 90-es évekbeli szlovén szerzők kevés kivétellel általában az országon kívüli, nemzetközi politikai vagy nagyhatalmi tényezőknek tulajdonítja. Ilyen például a Románia NATO-meghívását övező, az atlanti szövetségen belüli vita - a NATO tagjai közül Franciaország szorgalmazta Románia korai meghívását -, az amerikai szenátus egy részének szkepticizmusa a tömeges NATO bővítés iránt, vagy pedig az Egyesült Államok, illetve a tágabban értelmezett Nyugat Csehországgal, Lengyelországgal és Magyarországgal szembeni „morális adósságának” elmélete (lásd Kopac 2017, Bebler 1999c, 131-132, Barany 2003, 103-104, Gow és Carmichael 2000, 198-202). Ekkoriban a madridi kudarc belső szakpolitikai és különösen katonai jellegű okai aránylag kevés figyelmet kaptak. Anton Bebler és más szerzők nyomán ezek között a védelmi reformok elmaradását, a haderőt övező politikai vitákat, a megfelelő katonai képességek 
hiányát - mely részben az 1996-ig érvényben volt fegyverembargónak tulajdonítható -, a képzett tisztek alacsony számát, valamint a titokvédelmi intézményrendszer fejletlenségét említhetjük meg (Vankovska és Wiberg 2003, 181-182, Szilágyi 2002, 83, Bucar és Sterbenc 2002, 115).

Az elutasításban jelentős szerepet játszhatott, hogy a NATO több jelentős tagállama, különösen az Egyesült Államok megítélése szerint Szlovénia nem tett eleget a balkáni térség stabilizációja érdekében. Ilyen irányú kritikát fejtett ki a madridi csúcs után Ljubljanába látogató Madeleine Albright amerikai külügyminiszter is. Ezt megelőzően számos bírálat tárgyává vált az is, hogy az ország csak vonakodva kívánt részt venni a SECI (Délkelet-Európai Együttmüködési Kezdeményezés) munkájában, illetve, hogy Szlovénia - Macedóniával együtt - nem vett részt a boszniai IFOR misszióban sem (Szilágyi 2002, 79-82, Bucar és Sterbenc 2002, 126). Ugyanakkor a politikai elit egy részének magatartása is kelthette azt a benyomást, hogy a NATOtagság mellett csak szavakban elkötelezettek, azonban nem készek vagy hajlandók az atlanti szövetségbe való belépéssel járó feladatokat és kötelezettségeket is vállalni (Szilágyi 2002, 82-83). Mindez egybevág Grizold (1997c), illetve Grizold és Vegic (2001) azon megállapításával, hogy a politikai elit és a társadalom nagyobb része számára is elsődlegesen egyfajta presztízs szempontból volt lényeges a NATO csatlakozás, ellentétben például a balti államokkal, ahol a NATO-ba való belépést létező és releváns biztonsági fenyegetés is indokolta. Hasonló megfogalmazással él Keridis és Perry $(2004,5)$ amikor arról ír, hogy Szlovénia számára a csatlakozás inkább egy politikai cél, mint egy „kemény biztonsági” (hard security) cél volt. Malesic és Jelusic (2003b, 177-178) szerint ugyanakkor az 1997-es NATO elutasítás egy „politikai érési folyamat” elindítója is volt, amely hozzájárult a szlovén hadsereg reformjának felgyorsításához (Malesic 2017). Az 1997 és 2000 közötti időszak tapasztalatai arról tanúskodnak, hogy az említett politikai érési folyamat eredményei relatíve lassan jelentkeztek.

A szlovén kormány 1998. február 28.-án fogadta el a nemzeti NATO integrációs stratégiát, ami - ismereteim szerint - az első olyan dokumentum volt, mely a NATO csatlakozás deklaratív célul tủzésén túlmenően átfogó, konkrét szakpolitikai lépéseket is tartalmazó programot fogalmazott meg a NATO tagság elérése érdekében. A NATO-csatlakozás katonai aspektusait illetően a kormány ígéretet tett a fegyveres erők demokratikus és civil kontrolljának erősítésére, a honvédelmi törvény és a nemzetbiztonsági szolgálatokról szóló törvény módosítására, valamint a 
vezérkar NATO elvárásoknak megfelelö átszervezésére. A kormány rövid határidőn belül célul tüzte ki a katonai doktrína módosítását, illetve a Szlovénia biztonság- és védelmi politikájáról szóló Fehér Könyv elfogadását (Szilágyi 2002, 84). A NATOcsatlakozási erőfeszítések részét képezte a NATO-hoz akkreditált szlovén képviselet felállítása, valamint a csatlakozási teendők koordinálása érdekében tárcaközi munkacsoport létrehozása is (Barany 2003, 104). A NATO-bővítés második körében a tagjelöltek felkészülését a MAP (Membership Action Plan) kidolgozásával segítették, mely öt kulcsfontosságú területen határozza meg az egyes tagjelöltektől elvárt reformokat. A MAP keretében kidolgozandó éves nemzeti programok (Annual National Program, ANP) a már említett tárcaközi munkacsoport koordinálásával készültek (Barany 2003, 115). Szlovénia a kezdetektől 1999-től vett részt a MAPban, ugyanakkor, mint két szlovén szakértő megállapította, az ANP teljesítéséről készült első néhány éves jelentéssel kapcsolatban „érzékelhető volt a feszültség a deklarált elvek és a lehetőségek, a kívánságok és az elérésükhöz szükséges valóságos feltételek között”. (Cimpersek és Savc 2001, idézi Szilágyi 2002, 89). Hasonló véleményt fogalmazott meg Anton Grizold szlovén biztonságpolitikai szakértő 2000-2004 között honvédelmi miniszter - is, amikor úgy értékelte, hogy az első két szlovén éves nemzeti program nem reális célkitüzéseket tartalmazott (idézi Barany 2003, 116). Noha az ország az 1997-es fiaskót követően jelentős előrelépéseket tett a NATO-tagságra való felkészülés terén, számos probléma - például az átfogó stratégiai tervezés hiánya - továbbra is megoldatlan maradt. A további bővítésre ugyanakkor maga az atlanti szövetség sem volt még felkészülve, amit az is mutatott, hogy az 1999-es washingtoni csúcstalálkozón nem született döntés új tagok meghívásáról (lásd pl. Sabic és Bukowski 2002, Gow és Carmichael 2000, 200-201).

\subsubsection{A magyarázó tényezők hatásának értékelése}

A történelmi örökség hatása ezen az időszakban részben hasonló volt a korábbi, 1991-1994 közötti periódusban tapasztalhatóhoz. A szlovén hadsereg felépítésében, müködésében továbbra is jelen voltak az olyan elemek, melyek még a korábbi Területvédelem ,intézményi örökségének” tekinthetőek. Egyebek mellett a már említett 1995-ös katonai doktrína több ponton a épített a milíciaszerű és irreguláris felfogásra (Szilágyi 2002, 72-74), valamint a szlovén hadsereg fötisztjeinek egy része a kilencvenes években továbbra is a területvédelmi orientációt részesítette 
előnyben a politikai elit számára egyre inkább előtérbe kerülö kollektív védelmi orientációval szemben (Jelusic 2017).

A horvátországi és boszniai háború lezárulásával jelentősen kedvezőbbé vált Szlovénia biztonsági környezete, a konvencionális fenyegetések ebben a periódusban fokozatosan háttérbe szorultak. A délszláv háborúk ezen szakaszának lezárulása együtt járt a fegyverembargó feloldásával is. A biztonsági környezet javulása egyik feltétele volt annak, hogy a kilencvenes években megkezdődhetett egy olyan folyamat, mely a területvédelmi erő modern, NATO-kompatibilis haderővé alakítására irányult (Kopac 2017).

Hasonlóan az előző, 1991-94 közötti időszakhoz, ebben a periódusban is a belsö politikai folyamatok játszották a legfontosabb szerepet a vizsgált területen.

A gyakori miniszterváltások megnehezítették a szakpolitikai folyamatosság kialakítását, valamint lelassították a reformfolyamatot, illetve jellemző volt a stratégiai tervezés hiánya és például a képességfejlesztési prioritások gyakori változtatása is (Malesic 2017, Jelusic 2002, 118-119, Vankovska és Wiberg 2003, 177-178). Számos esetben az éppen hivatalban lévő miniszter elképzelése alapján, vagy a minisztériumon belül kialakult ad hoc koalíciók támogatásával került sor jelentős katonai beszerzésekkel kapcsolatos döntések meghozatalára (Jelusic 2017, Kopac 2017). Annak ellenére, hogy az említett ad hoc koalíciókban esetenként a fegyveres erők vezető tisztjei is részt vettek, a kilencvenes évek ezen időszakában a civil-katonai kapcsolatokat a civil (politikai) vezetés teljes dominanciája, és a katonatiszti réteg elhanyagolható mértékü érdekérvényesítő képessége jellemezte (Jelusic 2017, Bebler 2004, 128-130, Furlan 2013, 443).

A nemzetközi tényezök, közöttük a NATO hatása annak ellenére korlátozott maradt, hogy ekkorra már egyértelmüvé vált a szlovén kormányzat csatlakozási ambíciója és lépések is történtek a szlovén haderő NATO-tagságra történő felkészítése érdekében. Ennek fő oka az volt, hogy az atlanti szövetség a kilencvenes évek során alapvetően még nem mutatott érdemi fogadókészséget Szlovénia csatlakozására. A NATO-ba való meghívás 1997-es elmaradása ugyanakkor a szlovén reformfolyamat felgyorsulásához vezetett, a Csatlakozási Akcióterv (MAP) 1999-es bevezetés pedig több területen, különösen a képességtervezés területén, konkrét iránymutatások kialakításával segítette az ország felkészülését (Malesic és Jelusic 2003b, 177-178, Kopac 2017). A MAP-ban történő részvétel eredményei azonban már csak a 2000-et követő időszakban jelentkeztek. 


\section{4. "Szakértői kormányzás" a védelempolitikában és NATO- csatlakozás (2000-}

2004)

\subsection{1. Általános politikai trendek}

A 2000 és 2004 közötti periódusban a függetlenség elnyerése óta először került sor arra, hogy egy honvédelmi miniszter kitöltötte 4 éves mandátumát. Az Anton Grizold egyetemi tanár, védelempolitikai szakértő vezetésével müködő honvédelmi tárca sikeresen hajtotta végre azon reformokat melyek végül az ország 2002 decemberi NATO-ba való meghívását, illetve 2004 tavaszi NATO-csatlakozását lehetővé tették. A védelmi szférában ebben az időszakban bevezetett "szakértői kormányzás" részben annak tulajdonítható, hogy az 1997-es madridi „fiaskó” után a NATO-tagság elnyerése ekkor már kiemelt prioritásnak számított a szlovén politikai elit számára (Grizold 2014). Az időszak fö trendjét a szlovén hadsereg strukturális és funkcionális professzionalizálásának felgyorsítása jelentette (Malesic et al. 2015, 12).

A professzionalizáció ezen két formája szervesen összefüggött: a hivatásos hadseregre való áttérés (a strukturális professzionalizáció) lehetővé tette a külföldi missziókban való intenzívebb részvételt, míg a missziós munka során szerzett tapasztalatok elősegítették a szlovén hadsereg müködésében a professzionális szakmai standardok meghonosítását (Malesic et al. 2015 13-14.). A NATO-ba való meghívás mellett az időszak legfontosabb védelempolitikai kérdése a hivatásos hadseregre való áttérés volt, mely a katonai vezetés és a politikai elit, illetve a hadsereg és a tágabb társadalom közötti kapcsolatokat is érintette. Noha az önkéntes haderöre való áttérés nem szerepelt a NATO-hoz való csatlakozás feltételei között (Szlovénia csatlakozásának időpontjában több NATO-tagállam is sorozott hadsereget tartott fent), az atlanti szövetségben való tagság jelentette új feladatok és kötelezettségek újabb érvet jelentettek a sorkatonaság megszüntetése mellett. A sorkötelezettség felfüggesztését azonban más tényezők is motiválták. Ezek közül a kedvezőtlen demográfiai folyamatokat, a lelkiismereti szolgálatmegtagadás magas arányát, a sorozott hadsereg alacsony harckészültségét, illetve a sorkötelezettség intézményének növekvő népszerütlenségét érdemes megemlíteni (Malesic et al. 2015, 12, Kotnik és Kopac 2002, 165-167).

A NATO-felkészülés folyamatában, illetve a NATO-beli meghívást követően több alkalommal politikai véleménykülönbség volt megfigyelhető a védelmi minisztérium 
vezetői, illetve a fiatalabb tisztek, valamint a vezérkar néhány idősebb, karrierjüket a függetlenség háború alatt, vagy azt megelőzően, a Területvédelmi Erők kötelékében megkezdett tagja között. Az idősebb főtisztek közül többen nem értettek egyet a területvédelmi stratégiától való elmozdulással, illetve azzal, hogy a szlovén haderőnek a NATO tagjaként „out of area” bevetéseken és missziókon is részt kell vennie, valamint többen nehezményezték azt is, hogy a NATO egyszer, 1997-ben már elutasította Szlovéniát. Ez azonban tartósan nem befolyásolta negatívan a demokratikus civil-katonai kapcsolatokat, sem pedig az ország NATO-hoz történő csatlakozását sem (Hendrickson és Ethridge 2004, 119, Jelusic 2014).

A vizsgált időszakban alapvetően új elemnek tekinthető az átfogó stratégiai szemlélet érvényesülése a szakpolitika-formálásban és a szakmailag magasan képzett döntéshozók megjelenése a minisztérium csúcsvezetésében. Anton Grizold honvédelmi miniszter mellett megemlíthető, hogy Milan Jazbec, egy tapasztalt szlovén diplomata lett a minisztérium államtitkára, és a tárca NATO-val foglalkozó osztályához is több vezető tisztségviselö érkezett a szlovén Külügyminisztérium kötelékéből (Jazbec 2014, 38-39). A már említett átfogó stratégiai szemlélet érvényesítését segítette, hogy jelentősen javították a koordinációt a VM és a biztonsági-védelmi kérdésekben (és különösen a NATO-csatlakozás ügyében) illetékes szaktárcák, valamint a VM és a Szlovén Hadsereg vezérkara között (Jazbec 2014, 37-39, Grizold 2014). A tervezett átalakítások végrehajtását az is segítette, hogy a Szlovén Hadsereg tisztikarában ebben az időszakban jelentek meg nagyobb számban a fiatalabb, reformszemléletü, általában NATO-tagállamokban is továbbképzést kapott tisztek (Jelusic 2014).

\subsubsection{Jogi-intézményi és szervezeti változások}

Noha a Grizold-éra alatt számos korábban hiányzó vagy félbehagyott stratégiai dokumentumot és reformintézkedést fogadtak el, az új (2000-ben hivatalba lépö) minisztériumi vezetés ugyanakkor, legalábbis kezdetben, több ponton épített a megelőző két év reformkísérleteire is. A 2001-ben elfogadott Nemzeti Biztonsági Stratégia alapját például részben a Janša irányítása alatt 2000-ben előkészített javaslat képezte (Szilágyi 2002, 91). Az ekkoriban kidolgozott stratégiai dokumentumok több ponton építettek a szlovén védelmi szektorról szóló amerikai értékelés (az ún. Garrett-jelentés) javaslataira és megállapításaira is, mely még 2000 
nyarán készült el és került továbbításra a szlovén kormányzatnak (Keridis és Perry 2004, 6). Az új Nemzeti Biztonsági Stratégiát a szlovén parlament 2001. június 21-i ülésén fogadta el. A stratégia alapvető fontosságú célként jelöli meg a NATO-hoz és EU-hoz való csatlakozást mely Szlovénia érdekeinek hatékonyabb érvényre juttatásához és hozzájárulhat (ReSNV 2001, 1-2. pont).

A dokumentum „széles” biztonságfogalomra épül: a balkáni instabilitás további folytatódása mellett elsősorban nem katonai jellegü fenyegetéseket azonosít, úgy mint a terrorizmus, a tömeges illegális migráció, környezeti katasztrófák, transznacionális szervezett bünözés, valamint a gazdasági blokád lehetősége. Az energetikai blokádot a stratégia külön is említi, valamint kitér a kritikus infrastruktúrát érő támadásokra, közöttük a kibertámadások lehetőségére is. (ReSNV 2001, 3.2-3.3. pont) A szlovén hadsereg fő fejlesztési irányaként a dokumentum a mennyiségi felől a minőségi szempont felé való elmozdulást jelöli meg. Ennek eszközei a hivatásos katonák arányának emelése, a fegyverzet- és felszerelésmodernizáció, a flexibilisebb szervezeti struktúra kialakítása, a nemzetközi vállalások figyelembe vétele a haderő-átalakításban, illetve a katonai kiadások mértékének közelítése a NATO tagállamokban megszokotthoz. (ReSNV 2001, 4.2 pont)

Érdemes megemlíteni, hogy a Nemzeti Biztonsági Stratégia ekkor még nem jelölte meg célként a hivatásos hadseregre való teljes áttérést, mindössze a hivatásos katonák arányának növelése szerepel. A Grizold vezette minisztérium 2001-ben kiadott, négy éves munkaprogramja hasonlóan, rövid távú célként a hivatásos katonákból álló 10. gépesített gyalogsági zászlóalj feltöltését, a „sorkatonai szolgálat vonzerejének növelése érdekében motivációs intézkedések kialakítását”, valamint a toborzás alternatív lehetőségeinek vizsgálatát jelöli meg (RS Ministry of Defense 2001, 7-8). A sorkatonaság megszüntetése a dokumentumban a 2004-ig tartó időszakra vonatkozó középtávú célok között sem szerepelt. (RS Ministry of Defense 2001, 9-10). A Nemzeti Biztonsági Stratégia elfogadása mellett a parlament 2001ben elfogadta a kormány által felülvizsgált, a Szlovén Hadsereg hosszú távú fejlesztésére és felszerelésére vonatkozó alapprogramot (DPRO SV) is, melynek első változatát még 1999-ben fogadták el, célkitűzései azonban a megváltozott körülmények fényében irreálisnak bizonyultak (Kotnik és Kopac 2002, 151). A program bevezetőjében külön hivatkozik a NATO stratégiai koncepciójára, mely hatással van a Szlovén Hadsereg további fejlesztési irányára, illetve 
„kulcsfontosságúnak” nevezi, hogy az ország felkészüljön az Európai Unió közös biztonság- és védelempolitikája keretében való müködésre is (DPRO SV 2001, 1. pont). A felszerelési és fejlesztési terv is a sorkatonai szolgálat fenntartásával számolt a 2007-ig terjedő időszakban, azonban szükségesnek tartotta a hivatásos komponens növelését, a hivatásosokból álló készenléti vagy reagáló erők (sile za posredovanje) további fejlesztése útján. (DPRO SV 2001, 2.3 pont).

Mint korábban említettem, a kormányzat ugyan rövid távon 2001-ben nem számolt a sorkatonaság kivezetésével, de, a Grizold vezette tárca megbízást adott egy szlovén és nemzetközi kutatókból álló szakértői csoportnak a sorozott hadsereg lehetséges alternatíváinak megvizsgálására, illetve néhány fontosabb európai állam toborzási és hadkiegészítési rendszerének összehasonlító elemzésére. A szakértői bizottság 2001 és 2002 fordulóján fejezte be munkáját, melynek alapvető következtetése az volt, hogy a kedvezőtlen demográfiai folyamatok, a lelkiismereti szolgálatmegtagadás magas aránya, az egészségügyileg alkalmatlanok magas aránya, illetve a változó társadalmi attitüdök miatt már középtávon is nehezen tartható fent Szlovéniában a sorozott katonaság jelenlegi rendszere. (Malesic 2003, 173-174). A sorkatonaság fenntartása ellen szólt továbbá a változó biztonsági fenyegetettség a 90-es évekhez képest, a szlovén hadsereg növekvő nemzetközi kötelezettségei, a haderő modernizációja nyomán jelentkező magasabb képzettségi követelmények, melynek a 7 hónapos sorkatonai időszak során nem lehet eleget tenni, valamint a sorozott állomány alacsony harcértéke és -készültsége is (Malesic 2003, 175-182). A szakértők megállapították azt is, hogy a sorkatonaság további fenntartása mellett a rendszer müködőképességének megörzéséhez olyan intézkedésekre lenne szükség (mint például a lelkiismereti szolgálatmegtagadás feltételeinek szigorítása, az egészségügyi követelmények csökkentése, a sorkatonai szolgálati idő növelése, vagy, izraeli mintára, a nők sorkatonai szolgálatának bevezetése), melyek vagy politikai vagy szakpolitikai okokból nem valósíthatóak meg, illetve nem kívánatosak (Malesic 2003, 173-174, 183-184).

A fent elmondottak alapján a bizottság a hivatásos hadseregre történő átállást tartotta a legelőnyösebbnek az ország számára, azonban csak viszonylag lassan, öt éves átmeneti időszakot követően. Mint a szakértők hangsúlyozták, teljes bizonyossággal nem jelezhető előre, hogy a szerződéses hadsereg munkaerő-piaci feltételei adottak e, illetve, hogy mekkora költséggel jár az államháztartás számára a sorkötelezettség kivezetése (Malesic 2003, 181-182, 183-184). A nemzetközi bizottság jelentését is 
figyelembe véve a Védelmi Minisztérium szakértői két forgatókönyvet készítettek a hivatásos haderőre való átállásra. A minisztérium álláspontja alapján az erre vonatkozó döntést a kormányzatnak legkorábban 2004-ben kellene meghoznia, mivel a kérdéses időszakban (2002 elején) még nem volt ismert, hogy Szlovéniát meghívják e a NATO-ba, illetve a bizottság által is említett gazdasági- és munkaerőpiaci körülmények sem, valamint a Szlovén Hadsereg átalakítása is folyamatban volt. (Kotnik 2003, 193-194) Az „optimális” forgatókönyv szerint a sorozást legkésőbb 2006 december 31-én függesztenék fel, ezt két évvel követné a kötelező katonai szolgálat felfüggesztése, a kötelező tartalékos szolgálat pedig 2009 végén kerülne felfüggesztésre. A második, gyorsabb átmenetet feltételező forgatókönyv a sorozás 2004. június 30-i felfüggesztésével, illetve a sorkatonaság 2005 végi, valamint a tartalékos szolgálat 2008. június 30-ával történő kivezetésével számolt (Kotnik 2003, 194). A 90 tagú szlovén parlament 22 ellenzéki képviselője 2002 tavaszán terjesztett elő egy ennél is „radikálisabb” javaslatot, mely a sorozás azonnali felfüggesztését, illetve a sorkatonai szolgálat 6 hónapon és a kötelező tartalékos szolgálat 4 éven belüli kivezetését szorgalmazta (Kotnik 2003, 195). A vitában megszólalt Milan Kučan köztársasági elnök is, aki kétségeit fejezte ki a hivatásos haderőre való túl gyors átállással kapcsolatban (Szilágyi 2002, 94).

A védelmi tárca a fent említett okokból szintén ellenezte a túlzottan gyors átállást, azonban Janez Drnovsek miniszterelnök a gyorsabb professzionalizációt támogatta, ezért kompromisszumos döntés született. A 2002. április 25-én meghozott kormánydöntés alapján a sorozás felfüggesztésére 2003 végéig kerül sor, az utolsó sorkatonák 2004 június végén fejezik be szolgálatukat, a kötelező tartalékos szolgálat felfüggesztésének legkésőbbi dátuma pedig 2010 december vége lesz. Már 2002-ben megkezdik az önkéntes tartalékos szolgálat felállítását, a Szlovén Hadsereg jövőbeli hadilétszáma ${ }^{14}$ pedig 26000 lesz (ebből 8000 aktív állományú katona). A NATO-hoz való csatlakozást követően sor kerülhet a célzott hadilétszám további, 18000-re való csökkentésére, a tartalékos létszám „visszavágása” útján. (Kotnik 2003, 190, 194196). Ezáltal tehát a hivatásos hadsereg bevezetésének ügyében politikai döntés született, noha a szakmai szempontok a sorkötelezettség kivezetésének lassabb "tempóját" indokolták volna, mivel ekkor számos, az önkéntes haderőre való sikeres áttérést befolyásoló kockázati tényező (munkaerő-piaci körülmények, az önkéntes ${ }^{14}$ Egy hadsereg hadilétszámába a tartalékosok is beleértendők, míg a békelétszám a minden
körülmények között meglévő, állandó állományi létszám. 
haderő tényleges költségei, a hivatásos katonai pálya vonzereje) hatását nem láttak kellően elöre (Kotnik 2003, 193-194, 196). Fontos megemlíteni, hogy ez a szakmai vita a politikusok és a szlovén Védelmi Minisztérium szakértő-köztisztviselői között folyt, a katonai vezetés semmilyen formában nem jelent meg önálló tényezőként a vitában (Malesic 2017, Jelusic 2017). Svete és Jelusic (2009, 7-8) ezt a szlovéniai hivatásos katonai szakma érdekérvényesítő képességének hiányával indokolja. A 2002-es és 2003-as év során történt meg a honvédelmi törvény, a hadkötelezettségről valamint a katonai szolgálati jogviszonyról szóló törvény és a kapcsolódó végrehajtási rendeletek módosítása mely önkéntes haderőre való áttérés, illetve a NATO-csatlakozásra történő felkészülés miatt volt szükséges (Szilágyi 2002, 93-94, RS Ministry of Defense 2004, 11-13).

Ebben az időszakban, 2003 végére fejezték be az első stratégiai védelmi felülvizsgálatot (SPO) is, melynek az volt a célja, hogy a megváltozott nemzetközi körülmények (a küszöbön álló EU- és NATO-csatlakozás) és a hivatásos hadseregre való áttérés körülményei között vizsgálja meg a szlovén védelmi szektor föbb problémáit és jelölje ki a közép- és hosszú távú célkitüzéseket ezek megoldására (RS Ministry of Defense 2004, 11, 2004b, 8). Mint ahogy a dokumentum megállapította, a NATO-csatlakozással a védelmi tervezés rendszerét a szövetségben használatoshoz kell igazítani, fel kell készíteni a szlovén hadsereget a tagságból fakadó újabb kötelezettségek, így a nemzetközi müveleteken és missziókon való részvétel, hatékony ellátására, valamint fokozatosan növelni kell a NATO számára felajánlható képességeket is. (RS Ministry of Defense 2004b, 18-20). Személyzeti területen a SPO szerint problémát jelent a Szlovén Hadsereg hivatásos állományának kedvezőtlen életkori, rendfokozati és képzettségbeli összetétele, melyen célzott toborzással, a képzési és személyzetfejlesztési politika átalakításával, illetőleg a hivatásos személyzet számára életpályamodell kialakításával kívánnak változtatni. A korszerü védelmi rendszer kialakítása jelentős pénzügyi erőforrásokat kíván meg, ezért a dokumentum a védelmi kiadások fokozatos növelését irányozta elö, melyen 2008-tól érnék el a NATO által megkívánt GDP-arányos 2\%-ot (RS Ministry of Defense 2004b, 25-26, 31, 60). A NATO-hoz való csatlakozással szükséges a védelmi tervezés rendszerének átalakítása is, a középtávú védelmi tervek rendszerének bevezetésével, és ennek a NATO tervezési rendszeréhez való igazításával (RS Ministry of Defense 2004b, 29, 39).

A szervezeti struktúra területén a védelmi felülvizsgálat jelentős problémaként 
emelte ki, hogy a védelmi minisztérium belső felépítése és működése a 90-es évek óta nem sokat változott, az elavult és "egyre inkább öncélúvá váló" (RS Ministry of Defense 2004b, 66) szervezet nem képes hatékonyan elvégezni azokat az új feladatokat, melyeket a NATO- és EU-csatlakozás, valamint a hivatásos haderő bevezetése jelent a honvédelem területén. (RS Ministry of Defense 2004b, 64-66). Emiatt a dokumentum szükségesnek tartotta a személyzeti struktúra racionalizálását és a civil köztisztviselők képzettségének javítását (RS Ministry of Defense 2004b, 69). A Stratégiai Védelmi Felülvizsgálat ajánlásait figyelembe véve fogadták el 2004 júliusában a hadsereg új hosszú távú fejlesztési és felszerelési tervét, mely immáron a NATO-tagság körülményei között határozta meg a 2015-ig elérendő hosszú távú célokat. (ReDPRO SV 2004).

\subsubsection{A védelmi szféra nemzetközi dimenziója}

A Szlovén Hadsereg nemzetközi szerepvállalását illetően különbséget kell tenni a balkáni béketeremtésben és stabilizációban való részvétel, illetve a Bushadminisztráció által meghirdetett terror elleni háború keretében megindított iraki és afganisztáni hadműveletek között. Szlovénia a vizsgált időszakban fokozódó mértékben vett részt a balkáni missziókban, az afganisztáni és iraki beavatkozást illetően azonban a szlovén álláspont az előbbi esetében ambivalens, az utóbbi esetében kifejezetten ellenző volt, és ez az ország ezen missziókban való részvételében is megmutatkozott. A volt Jugoszlávia területén müködő nemzetközi missziókban ezzel ellentétben növekvő szlovén szerepvállalásról beszélhetünk: az SFOR mellett 2000-től az ország a koszovói KFOR-ban is részt vett, 2002-től pedig egy teljes század teljesített szolgálatot az SFOR-ban (ez volt az első alkalom, hogy egy teljes szlovén egység került kiküldésre). 2002-től a szlovén ISAF-részvétel kezdetéig (2004 tavasza) szinte a teljes szlovén missziós részvétel a Balkánra irányult (RS Ministry of Defense 2004, 10-11, RS Ministry of Defense 2005, 18-19, Malesic et al 2015, 83, 85).

A 2001. szeptember 11.-i terrortámadást követően Szlovénia szolidaritást vállalt az Egyesült Államokkal, az afganisztáni hadmüvelethez azonban kezdetben csak humanitárius segítség nyújtására tett ígéretet. A szlovén kormány a katonai szerepvállalással kapcsolatban arra hivatkozott, hogy nem állnak rendelkezésre a szlovén katonák helyszínre szállításához szükséges képességek, a döntés hátterében 
azonban valójában az állhatott, hogy Ljubljana nem kívánta, hogy a belpolitikailag népszerütlen afganisztáni szerepvállalás befolyásolja a küszöbön álló NATOcsatlakozás támogatottságát (2003-ben népszavazás döntött a NATO-ba való belépésről) (Hendrickson 2002, 73). A következő két évben, 2002-ben és 2003-ban Szlovénia valóban nem küldött csapatokat Afganisztánba, azonban feleslegessé vált készleteikből kézi- és könnyüfegyvereket ajánlottak fel az afgán fegyveres erők részére (Hendrickson és Rudy 2003, 52-53). Már a NATO-ba való meghívást követően, 2004 tavaszán döntött úgy a szlovén kormány, hogy rendfenntartó és őrzés-védelmi feladatokra küldenek katonákat Kabulba (Hendrickson és Ethridge 2004, 120).

Az iraki konfliktussal kapcsolatban Szlovénia kezdetben szintén ambivalens álláspontot foglalt el. Dimitrij Rupel szlovén külügyminiszter 2003-ban aláírta az ún. Vilniusi csoport levelét, mely Irak ügyében az amerikai álláspontot támogatta. Anton Rop miniszterelnök azonban a háború kitörését követően sajnálatosnak nevezte, hogy a katonai megoldás alkalmazására került sor, ugyanakkor egyértelmüvé tette, hogy Szlovénia nem kíván részt venni az iraki hadmüveletben, és ebben a kérdésben a NATO-n belül a francia-német irányvonalat támogatja (Hendrickson és Rudy 2003, 53). Az iraki háború kitörése időben egybeesett a NATO-ról tartott szlovéniai népszavazással, így ebben az esetben is a belpolitikai szempontok szerepet játszhattak a döntésben, mivel az amerikai beavatkozás igencsak népszerütlen volt Szlovéniában. A szlovén kormány így a választók felé azt az üzenetet közvetíthette, hogy a NATO nem egyenlő az Egyesült Államokkal, tekintve, hogy az európai NATO-tagok megosztottak voltak az „Iraki szabadság” hadmüvelet kérdésében (Hendrickson és Rudy 2003, 53-54). Az iraki háborúval kapcsolatos említett szlovén miniszterelnöki nyilatkozat ugyanakkor megelőzte a bővítésről szóló amerikai szenátusi szavazást is, Szlovénia volt az egyetlen 2004-ben a NATO-hoz csatlakozó ország, mely az iraki háborúval kapcsolatban nem az amerikai álláspontot támogatta (Hendrickson és Rudy 2003, 53-54). Már csatlakozása után, a 2004 júniusban tartott isztambuli NATO csúcstalálkozón Szlovénia támogatta az iraki katonaság kiképzésére irányuló NTM-I NATO misszió létrehozását, azonban kikötötte, hogy a szlovén katonák csak harmadik országokban (Irakon kívül) fognak a kiképzési tevékenységben részt venni (Hendrickson és Ethridge 2004, 121).

Az ebben a periódusban végrehajtott reformintézkedéseknek köszönhetően az ország jelentős előrehaladást ért el a NATO-felkészülés terén és 2002-re reálissá vált 
Szlovénia NATO-ba történő meghívása, a döntéshozók számára bizonytalansági tényezőt jelentett, hogy a korábbi jellemzően támogató állásponttal szemben a szlovén társadalom egy része eddigre kifejezetten szkeptikus vagy elutasító volt a NATO-ba való belépéssel szemben (Szilágyi 2002b, 74-76, 80-82). Noha a politikai elit túlnyomó többsége támogatta a NATO-ba való belépést, a közvélemény, a civil társadalom és a sajtó egy része NATO-szkeptikus, vagy kifejezetten NATO-ellenes álláspontot képviselt. A 2000-es választáson parlamentbe került pártok közül a nacionalista Szlovén Nemzeti Párt (SNS) volt a csatlakozással kapcsolatban szkeptikus, míg a baloldali ellenzéki Egyesült Lista (ZLSD) párt ifjúsági- és nőtagozata ellenezte a NATO-tagságot (Szilágyi 2002, 98-99, Hendrickson 2002, 6869, Hendrickson és Rudy 2003, 52). A csatlakozással szembeni álláspontot foglalt el a sajtó illetve a kulturális elit egy része is (Bebler és Jazbec 2010, 54). A szlovén katolikus egyház ugyanakkor határozottan támogatta a NATO-csatlakozást, mert a tagságot az ország nyugati civilizációhoz való tartozásának szimbólumaként tekintették (Hendrickson 2002, 68, Svete és Jelusic 2009, 5).

A NATO-ellenes társadalmi csoportok meglehetősen heterogénnek tekinthetők, illetve az atlanti szövetséghez való csatlakozás elleni érvek is meglehetősen szerteágazóak voltak. Az ellenzők egy csoportjának álláspontja pusztán információhiányból fakadt, míg mások a regnáló szlovén kormányzattal szembeni ellenérzésüket kívánták így kifejezésre juttatni. A hagyományos, ortodox szélsőbaloldali NATO-ellenesek számára a NATO a kapitalizmus, a globalizáció, illetve az amerikai imperializmus szimbólumának számított, valamint véleményükben szerepet játszott a titói Jugoszlávia és az elnemkötelezettség politikája iránti nosztalgia is. A baloldal egy másik csoportja számára a NATO egy militarista szervezet volt, a csatlakozást a katonai kiadások növekedése miatt is ellenezték (Bebler és Jazbec 2010, 55). A környezetvédő szervezetek körében volt jelen egy olyan aggodalom, hogy a NATO csatlakozás miatt esetlegesen atomfegyvereket telepítenek az ország területére. Ezen aggodalom hátterében az is állhatott, hogy a szlovén parlament 2001-ben törvényt fogadott el arról, hogy engedélyezik Szlovénia területi vizeinek használatát atommeghajtású, ill. atomtöltetekkel felszerelt tengeralattjárók számára (Hendrickson 2002, 68).

A szlovén NATO-felkészülés utolsó néhány éve egybe esett az Európa számos országában, így Szlovéniában is igencsak népszerütlen George W. Bush vezette amerikai adminisztráció első hivatali ciklusával, így ez is vezethetett ahhoz, hogy 
számos NATO-ellenes választópolgár a NATO-t az Egyesült Államokkal, az USA-t pedig Bush politikájával azonosította (Bebler és Jazbec 2010, 55). Érdemes megemlíteni, hogy a NATO-csatlakozást ellenzők egy része kifejezetten, esetenként irreálisan pozitív véleménnyel volt a szlovén EU-tagságról, vagy az EU-csatlakozást az atlanti szövetségbe való belépés alternatívájának tekintette (Bebler 2004b, 232). A szlovén kormány a 2003-as népszavazást megelőző időszakban kiterjedt média- és tájékoztató kampány keretében népszerüsítette a NATO-csatlakozást, egyebek mellett a szlovén védelmi miniszter is országjáró körúton vett részt, ahol a helyszínen válaszolt a szavazók ezzel kapcsolatos kérdéseire. A kormányzati kampány is szerepet játszhatott abban, hogy a 2003. március 23-án megtartott voksoláson 60\%os részvétel mellett a választópolgárok 66\%-a igent mondott a NATO-hoz való csatlakozásra (Grizold 2014, Jazbec 36). Hendrickson és Rudy (2003, 52) szerint a népszavazás kimenetelében szerepet játszhatott, hogy a voksolást alig 10 nappal előzte meg a Zoran Djindics szerb miniszterelnök elleni belgrádi merénylet, mely arra emlékeztethette a szlovén választókat, hogy a szomszédos balkáni térség instabilitása korántsem a múlté. Noha a NATO a csatlakozáskor megköveteli, hogy a tagjelölt országok a belépés előtt rendezzék szomszédaikkal jogvitáikat, az egyebek mellett a Pirani-öböl kérdésével kapcsolatos horvát-szlovén viták nem okoztak problémát a szlovén NATO csatlakozás során, mivel a két ország a vita döntőbírósági megoldásáról állapodott meg. Petar Stipetić, horvát vezérkari főnök még 2002-ben úgy nyilatkozott, hogy a szlovén-horvát bilaterális katonai kapcsolatok a legjobbak a posztjugoszláv régióban (Hendrickson 2002, 67-68). Szlovénia és Horvátország 2003-ban katonai együttmüködési megállapodást is kötött (Hendrickson és Rudy 2003, 49).

\subsubsection{A magyarázó tényezök hatásának értékelése}

A történelmi örökség 2000 és 2004 között az általam vizsgált területre igen korlátozottan gyakorolt hatást: leginkább a társadalom NATO-csatlakozással szemben ellenséges részének attitüdjében mutatható ki a jugoszláv örökség szerepe, az elnemkötelezettség iránti „nosztalgia”, valamint a 80 -as években is jellemző pacifista irányzatok révén (Bebler és Jazbec 2010, 55).

A fenyegetés-környezet hatása ebben a periódusban elhanyagolható volt, mivel a hagyományos biztonsági fenyegetések szerepe visszaszorult, és az ekkor elkészült 
stratégiai dokumentumok, mint például a Nemzeti Biztonsági Stratégia (ReSNV 2001, 3.2-3.3. pont), és a Stratégiai Védelmi Felülvizsgálat (RS Ministry of Defense $2004 b$ ) is a nem konvencionális fenyegetéseket helyezik elötérbe, valamint a társadalom is elsősorban ezeket érzékelte releváns fenyegetésként (ld. Kotnik és Kopac 2002, 156-157).

A belsö politikai környezet 2000 és 2004 között is érdemi szerepet játszott a szlovéniai civil-katonai kapcsolatok alakulásában. A Grizold vezette tárca sikeresen teremtette meg a szakpolitikai folyamatosságot a védelmi területen, csökkent a szakterület átpolitizáltsága, valamint gyakorlati szinten is sor került azon intézkedések megtételére vagy felgyorsítására, melyek a szlovén politikai és szakértői elitben a kilencvenes évek közepe óta létező NATO-csatlakozási szándék megvalósításához szükségesek voltak (Grizold 2014, Jelusic 2014).

A sorkötelezettség megszüntetése, noha nem volt formális feltétele a NATO-hoz való csatlakozásnak, szintén abba az ezen időszakban lezajló folyamatba illeszkedett, melynek nyomán megtörtént a Szlovén Hadsereg átállása a milícia jellegü területvédelmi erőtől a kisebb létszámú, jobban képzett, nemzetközi szerepvállalásra hajlandó és korlátozott keretek között, nemzetközi szerepvállalásra is képes haderöre (Malesic et al. 2015 12-14). A NATO-csatlakozásról szóló sikeres népszavazás, valamint a NATO-ba való belépés nyomán politikai értelemben is ,pont került” az ezzel kapcsolatos viták végére. Ugyanakkor, pont a sorkötelezettség megszüntetéséről szóló vita is mutatta, hogy a hivatásos katonatiszti réteg szakmai érdekérvényesítő potenciálja továbbra is igen csekély volt (Jelusic 2017, Malesic 2017).

A teljes, 1991 és 2011 közötti időszakot tekintve ebben a periódusban volt a legerősebb a nemzetközi szereplők szerepe (Kopac 2017). Ebben a periódusban megítélésem szerint "találkozott" a sikeres NATO-felkészülésre irányuló belső politikai akarat (szakértő miniszter kinevezése, szakpolitikai folyamatosság, tervszerü szakpolitikai döntéshozatal), a NATO felöli fogadókészséggel, valamint a tagságra való felkészülés-felkészítés strukturált és intézményesített formáinak (pl. a NATO MAP) meglétével. Építve a tárca vezetői és a NATO egyes vezető tisztségviselöi közötti személyes kapcsolatokra is (Grizold 2014), létrejött egy olyan, szlovéniai és NATO-szereplőkből álló „transznacionális koalíció” (Epstein 2005, 6970, lásd még az 5.4. fejezetben), mely előmozdította a csatlakozáshoz szükséges reformok végrehajtását. 


\subsection{Szlovénia a NATO-tagság első éveiben (2004-2011)}

\subsection{1. Általános politikai trendek}

A NATO-felkészülést szolgáló reformok bevezetése és sikeres NATO- és EUcsatlakozást követően az általam vizsgált utolsó időszak inkább a "konszolidáció" periódusaként jellemezhető. Ugyanakkor, mint Milan Jazbec megjegyzi, az euroatlanti integráció egy folyamatnak tekinthető, mely a csatlakozással még korántsem zárult le (Jazbec 2014, 34). Ezen időszak politikai és szakmai vitái, problémái jellemzően "implementációs" viták és kérdések voltak, melyek az előző időszakokban meghozott döntések (NATO-csatlakozás, önkéntes haderőre való átállás) megvalósításához kapcsolódtak, vagy ezek következményeiként értelmezhetőek. A Védelmi Minisztérium élén alapvetően a folyamatosság volt jellemző 2004 és 2011 között, miniszterváltásokra csak a választásokat követően került sor. Karel Erjavec, a Szlovén Nyugdíjaspárt (DeSUS) vezető politikusa - 2005töl elnöke - a 2008 novemberi, míg Ljubica Jelusic egyetemi tanár, védelempolitikai szakértő a 2011 decemberi választásokat követő új kormány hivatalba lépéséig látták el feladatukat, tehát mindkét tárcavezető kitöltötte hivatali idejét (Jelusic 2014, Ministrstvo za obrambo RS 2017). Az időszak végére tulajdonképpen befejeződött a szlovén haderő strukturális professzionalizációjára - azaz az önkéntes haderő bevezetésére - irányuló program végrehajtása (RS Ministry of Defense 2012, 11), ez azonban nem mondható el a haderő funkcionális professzionalizálásáról, valamit a minisztérium apparátusának átalakítása is viszonylag lassan haladt. A minisztérium létszáma a szlovén haderő méretéhez viszonyítva továbbra is túlméretezett volt, valamint az ott dolgozó köztisztviselők egy részének felkészültsége sem felelt azon elvárásoknak, melyek ahhoz szükségesek, hogy az ország sikeresen müködtesse védelmi szektorát a NATO tagjaként (Grizold 2014, Jelusic 2014).

A minisztérium apparátusát továbbra is a civil köztisztviselők dominanciája jellemezte (az apparátus létszámának 12\%-a volt katona), azonban többször előfordult az a gyakorlat is, hogy korábbi katonatiszteket neveztek ki vezető köztisztviselői pozíciókba, vagy civil és katonai vezető pozíciók között folyamatosan "áthelyeztek" (Furlan 2013, 443-445).

Az ország, a 2004-ben az EU-hoz csatlakozott államok közül elsőként, 2008 első félévében látta az az Unió soros elnöki posztját. A biztonság- és védelempolitika 
területén egyebek mellett az EU Csádba és a Közép-Afrikai Köztársaságba küldendő missziója (EUFOR Chad/CAR), a nyugat-balkáni országok biztonsági és védelmi reformjainak támogatás, valamint a boszniai EUFOR-Althea misszió jövője voltak a szlovén elnökség napirendjén (RS Ministry of Defense 2009, 7).

A 2008-ban kezdődő világgazdasági válság a szlovén védelmi szférára is jelentős hatást gyakorolt: Kopac (2017) és Malesic (2017) szerint Szlovéniában a hadsereg volt a pénzügyi válság és az eurozóna válság fo „kárvallottja”. A kiadások csökkentésére föként a fegyverzet- és eszközbeszerzés területén került sor, így a bér jellegü kiadások a teljes védelmi költségvetésen belül az időszak második felében folyamatosan növekvő arányt mutattak (Kopac 2017, RS Ministry of Defense 2010, 64-65, 2012, 101, Jelusic 2014). A gazdasági recesszió és a növekvő munkanélküliség viszont növelte a szerződéses katonai pálya vonzerejét is, így a hadsereg 2008 előtti létszámgondjaira ilyen formában sikerült, legalábbis részben, "megoldást találni" (Kopac 2017, RS Ministry of Defense 2008, 39, 2010, 62-63). Ugyanakkor érdemes megemlíteni, hogy a jelentősebb védelmi kiadáscsökkentésekre, ezen belül a katonai beruházások, eszközbeszerzések különösen drasztikus "visszavágására" már az euróválság 2010-11-es kibontakozását követően került sor, ez a kérdés tehát részben túlmutat a dolgozat időbeli keretein (Malesic et al 2015, 70-71, Ministrstvo za obrambo RS 2017b, 83).

A 2004 és 2011 közötti periódus kapcsán három, ezen időszakban aktuális kérdést fogok röviden tárgyalni, melyet témám szempontjából lényegesnek tartok. Elsőként megvizsgálom az a kérdést, hogy milyen hatással járt az önkéntes katonaság 2002-es bevezetése és az átállás a 2004 utáni időszakban történtő megvalósítása a szükebben és tágabban értelmezett civil-katonai kapcsolatokra. Ebben az időszakban került sor több jelentős katonai eszközbeszerzésre is, melyek esetenként korántsem nélkülözték a problémákat. Ennek kapcsán röviden ismertetem a független Szlovénia történetének egyik legnagyobb korrupciós botrányát, az ún. Patria ügyet, mely ebben az időszakban bontakozott ki és szintén katonai beszerzéshez kapcsolódott. Végezetül a NATO- és EU-csatlakozást követően intenzívebbé vált szlovén külföldi missziós szerepvállalás kapcsán külön kitérek a külföldi katonai missziók szlovéniai társadalmi megítélésére és az ezzel kapcsolatos politikai vitákra.

A 2004 és 2008 közötti időszakban a hadsereg folyamatos létszámhiánnyal nézett szembe, emiatt a 2005-2010 és a 2007-2012 középtávú védelmi programban foglalt állományi célkitüzéséket sem sikerült teljesíteni (Svete és Jelusic 2009, 9-10). 
A szerzők értékelése szerint ennek okai sokrétüek: egyebek mellett a szerződéses katonai szolgálat biztosította jövedelem nem volt versenyképes a jelentős gazdasági növekedés körülményei között a versenyszférában elérhető fizetésekhez képest. Szerepet játszhatott ugyanakkor, hogy a bemeneti követelmények túl szigorúak voltak, például a kettős állampolgárságú jelentkezők automatikusan elutasításra kerülnek (Svete és Jelusic 2009, 12). A Védelmi Minisztérium adatai szerint 2007ben 600 fó hiányzott a tervezett állományi létszámból. (RS Ministry of Defense 2008, 39). A negatív trend 2008-ban fordult meg, ekkor már a hadsereghez újonnan csatlakozó szerződéses katonák száma meghaladta az onnan távozókét, míg 2009ben már 400 fö volt a nettó állományi növekmény. A szerződéses katonai pálya vonzerejének növekedése a gazdasági recesszióval és a jól fizető alternatív munkalehetőségek körének szükülésével is magyarázható, de szerepet játszhatott a minisztérium által beindított toborzási kampány, valamint a szerződéses katonai szolgálathoz kapcsolódó juttatások rendszerének átalakítása is, mely a katonai szolgálati jogviszonyról szóló törvény 2007-es elfogadásával történt meg. (RS Ministry of Defense 2009, 41, RS Ministry of Defense 2010, 62-63, Svete és Jelusic 2009, 12-13, Malesic et al. 2015, 60, 64-65). A korábbi fejezetekben említett, a szlovén haderő politikai semlegességére és politikai "inaktivitására" vonatkozó tendenciák nem változtak az önkéntes haderő bevezetésével sem. Ugyanakkor, mint Malešič és szerzőtársai $(2015,63)$ megállapítják, a szerződéses katonák érdekeit védő szakszervezetek tevékenysége esetenként nem nélkülözte a politikai felhangokat. Nem igazolódtak be azok a félelmek sem, amelyek szerint az önkéntes haderőre való átállás a szlovén hadsereg "társadalmi izolációját" fogja növelni: az önkéntes haderőre történő áttérést követően is alapvetően magas maradt a fegyveres erők iránti társadalmi bizalom, valamint a hadsereg társadalmi legitimitását növelte, hogy a szerződéses katonákat a korábbinál intenzívebben vonták be a katasztrófavédelmi tevékenységbe, és erre irányuló külön kiképzésben is részesítették (Malesic et al 2015, 64-65, 126-127). A sorkatonák ilyen célú alkalmazása Szlovéniában ugyanis nem volt jellemző (Jelusic 2005, 85-86).

A NATO-csatlakozást követően a kormányzat célul tüzte ki, immár a NATOfelajánlásokat és a nemzetközi missziókon való részvételt is szem előtt tartva a Szlovén Hadsereg további képességfejlesztését, emiatt ebben a periódusban több jelentősebb katonai beszerzésre is sor került. A beszerzéseket azonban több esetben problémák is kísérték, melyek, egyebek mellett az eljárásban részt vevő tisztviselők 
tapasztalatlanságából, a beszerzésben érintett szervezeti egységek közötti koordináció hiányából, és a belső ellenőrzés és kockázatkezelés elégtelen voltából fakadtak (Malesic 2015 et al, 41). Noha a beszerzésekről a döntést a Védelmi Minisztérium hozta meg, továbbá a beszerzési folyamatban is a minisztérium köztisztviselöinek volt a legnagyobb szerepe, a közvélemény az egyes beszerzésekkel kapcsolatos kritikái általában a katonai vezetés felé irányultak. A szlovén parlament védelmi bizottságának ülésein is elsősorban a katonai vezetés képviselői indokolták az adott beszerzés szükségességét, noha a beszerzésben korlátozott szerepet játszottak (Malesic et al. 2015, 62). Furlan (2013, 441-442) kutatásai alapján nem volt egyértelmű a gyakorlat arra nézve sem, hogy a miniszter kéri e a vezérkar szakvéleményét az egyes beszerzésekkel kapcsolatban, vagy hogy ezek a vélemények játszanak-e, és ha igen, milyen szerepet a későbbi döntésekben. A szerző arra is talált példát amikor a vezérkari főnök saját szakvéleményét a politikai elvárásoknak megfelelően alakította. A pénzügyi és költségvetési kontroll funkció ellátásában a Parlament védelmi bizottságának munkáját a kellő tapasztalatok, valamint a szakmai támogató személyzet hiánya is nehezítette, valamint a bizottság munkájában, és tagjainak állásfoglalásaiban a pártfegyelem a szakmai szempontoknál nagyobb szerepet játszott (Malesic et al 2015, 62, 70).

A Patria AMV közepes páncélozott harcijárművek beszerzésére irányuló tender megítélésem szerint a szlovéniai katonai beszerzésekkel kapcsolatos problémák egyik "állatorvosi lovát" képezi, ezért hasznosnak tartom e helyütt ezen beszerzés rövid ismertetését.

A 135 db közepes páncélozott harcjármü beszerzését még a 2004-ben elfogadott hosszú távú fejlesztési és felszerelési terv, illetve a 2005-2010 középtávú védelmi program irányozta elő, elsősorban a NATO-felajánlásokat, valamint a nemzetközi missziós részvételt tartva szem előtt (ReDPRO SV 2004, 4.2./1. pont). A járművekre a szlovén védelmi minisztérium 2006 elején írta ki a tendert, és Karel Erjavec védelmi miniszter 2006 júniusában jelentette be, hogy a finn többségi állami tulajdonú Patria vállalat Patria AMV termékét választották (Defense Industry Daily 2014, Jane's Defense Weekly 2006a). Szlovéniában politikai vita robbant ki arról, hogy a Patria cég ajánlata volt e a legkedvezőbb, és ebben az ügyben a parlamenti honvédelmi bizottság ülése is összehívásra került, ahol Albin Gutman vezérkari főnök is támogatását fejezte ki a Patria-üzlet iránt. (RTV Slovenija 2006a, 2006b, Slovenian News Agency 2006a). A parlamenti honvédelmi bizottság és a kormány 
között hosszú vita bontakozott ki azzal kapcsolatban, hogy a képviselök milyen mértékben ismerhetik meg a Patria-szerződés részleteit. Amikor a képviselök végül teljes hozzáférést kaptak az ügy iratanyagához, Erjavec védelmi miniszter nyilvánosan is elismerte, hogy a parlament által elfogadott hosszú távú fejlesztési és felszerelési tervben, valamint a középtávú védelmi programban szereplő 135-ös keretszám tartása érdekében 25 db jármü "felszerelés nélküli" vagy "alapverziós" lesz, további 55 pedig csak könnyüfegyverzettel lesz felszerelve (Jane's Defense Weekly 2006b, RTV Slovenija 2006c, 2007a, 2007b). Az első Szlovéniának gyártott Patria AMV jármű átadására még 2007 végén került volna sor, az ekkori tervek szerint az első 13 járművet a hadsereg a sikeres tesztek lezárulta után 2008 második felében már használatba is vehetné (Jane's Defense Weekly 2007). Időközben 2008 nyarán vesztegetés gyanújával Finnországban a Patria cég több alkalmazottját, közöttük a vállalat vezérigazgatóját is őrizetbe vették, 2008 szeptemberében pedig a finn YLE közszolgálati televízió egy riportmüsort sugárzott, melyben először hangzottak el korrupciós vádak egyebek mellett Janez Janša akkori miniszterelnök, valamint több szlovén vezető politikus ellen a Patria AMV-ügylettel kapcsolatban. (Slovenia Times 2015, Defense Industry Daily 2014)

A 2008 szeptemberi választás után hatalomra kerülő balközép kormánykoalícióban a Patria AMV ügylet kezdettől fogva éles belső viták tárgya volt: a koalíciós pártok egy része a szerződés felmondását, míg például a védelmi miniszter, Ljubica Jelusic, annak újratárgyalását tartották volna szükségesnek (Slovenian News Agency 2009a, 2009b)

A 2008-ban kezdődő gazdasági válság miatt pedig tarthatatlanná vált a korábbi védelmi tervek azon célkitűzése, hogy 2008-ra a katonai kiadások elérik a GDP 2\%át és legalább 2015-ig ezen a szinten maradnak, ebből következően az eredetileg tervezett 135 darab harcjármű beszerzésére sem volt anyagi forrás. (Slovenian News Agency 2008, 2009c).

Magával a beszerzéssel kapcsolatban is újabb visszásságokra derült fény: a szlovén Számvevőszék 2009 nyarán közzétett jelentése szerint nem voltak világosak a kormány célkitűzései a harcijárművek beszerzésével kapcsolatban, a kiválasztásnál a minisztérium nem teremtett versenyhelyzetet, mely csökkenthette volna az árat, a betervezett pénzügyi források nem voltak elegendőek a tervekben szereplő felszereltségü járművek megvásárlására, valamint a szállítással kapcsolatos határidőcsúszások ellenére a kormány nem, vagy csak későn élt kötbérigényével a 
szállítók felé (Slovenian News Agency 2009d). A számvevőszéki jelentés nyilvánosságra hozatalát követően az új védelmi miniszter megerősítette azt is, hogy az előző kormány által kötött szerződés szerinti 135 darab jármüből 25 darab mindössze üres karosszéria, nemcsak felszerelés és fegyverzet, de motor, hajtómü és kerekek nélkül (Slovenian News Agency 2009e). Müszaki problémák miatt a szlovén hadsereg csak 2009 nyarán vette használatba az első jármüveket, melyből 2011-ig összesen 30 darab érkezett. A Patria AMV-ket külföldi missziókon, Koszovóban és Afganisztánban is bevetették (RS Ministry of Defense 2012, 19, Jane's Defense Weekly 2009, 2010).

A koalíció belső vitái miatt a 2011-ig hivatalban lévő Pahor-kormány idején nem született végleges döntés a Patria AMV ügylet sorsáról. A szlovén kormány, a Patria és a finn vállalat szlovéniai partnere 2012 szeptemberében állapodtak meg a szerződés közös megegyezéssel történő felbontásáról, a megegyezés keretében eltekintettek a már megvásárolt 30 darabon felüli mennyiség leszállításától. (Slovenian News Agency 2011a, Jane's Defense Weekly 2011, Reuters 2012).

A Patria AMV-ügylettel kapcsolatban Szlovéniában, Finnországban és Ausztriában több bírósági eljárásra is sor került. Karel Erjavec korábbi védelmi minisztert valamint a 2009-ben menesztett Albin Gutman vezérkari főnököt hütlen kezelés miatt állították bíróság elé, azonban 2011-ben mindkettőjüket felmentették. (Slovenian News Agency 2009b, Slovenia Times 2015). Janez Janša akkori miniszterelnököt 2013-ban első fokon majd 2014-ben jogerösen letöltendő szabadságvesztésre ítélték kenőpénz elfogadásáért. Az ítéletet 2015-ben az Alkotmánybíróság hatályon kívül helyezte, és az első fokú bíróságot új eljárás lefolytatására utasította, erre azonban elévülés miatt nem került sor. (Slovenia Times 2015, Reuters 2015).

Érdemes megemlíteni, hogy a vezérkari főnök letartóztatása ellenére, a katonai vezetés önálló tényezőként nem jelent meg a Patria-beszerzésről szóló vitákban. (Harangozó 2012, 29.) Épp ellenkezőleg, Branimir Furlan szerint arra láthatunk példát, hogy az akkori vezérkari főnök 2006-ban a politikai elvárásoknak megfelelően alakította ki véleményét a beszerezni szükséges járművek mennyiségét illetően, még akkor is ha ez rosszabb felszereltségű jármüparkot eredményezett (Furlan 2013, 448-449). Hasonlóképpen vélekedik Jelusic (2017) is, amikor úgy fogalmaz, hogy a politika a beszerzésről szóló (a politikusok által történt) döntéshozatalt követően „felhasználta” a hadsereg vezetőit arra, hogy 
„szakemberként” indokolják meg a nyilvánosság előtt a Patria-projekt előnyös voltát. A kormány és a honvédelmi bizottság közötti viták miatt pedig mint említettem, kezdetben a törvényhozás sem tudta megfelelően ellátni kontroll feladatát (Furlan 2013, 441, 448-449). A Patria-ügy nem csak a politikai osztály iránti állampolgári bizalom további csökkenéséhez vezetett, hanem a hadsereg társadalmi megítélésére is negatívan hatott egy olyan időszakban amikor a közvélemény az afganisztáni missziót övező politikai viták miatt amúgy is szkeptikusabbá vált a fegyveres erőkkel szemben, illetve a gazdasági válság miatt jelentős társadalmi igény volt a védelmi kiadások csökkentésére is (Malesic et al. 2015, 119-120, 129-130). Ugyan az ügy főszereplői a politikai osztály tagjai, magas rangú (civil) köztisztviselők, valamint vállalati lobbisták voltak, a botrány következményei mégis a hadsereg társadalmi megítélését érintette negatívan: ilyen értelemben tehát a Patria-botrány „áldozata” volt (Malesic 2017).

\subsubsection{Jogi-intézményi és szervezeti változások}

A jogi és intézményes környezet szempontjából az időszak első felében a középtávú védelmi tervezés rendszerének kialakítása, valamint az új katonai doktrína elfogadása, míg a periódus második részében a második stratégiai védelmi felülvizsgálat befejezése, a főbb stratégiai dokumentumok megújítása (a Nemzeti Biztonsági Stratégia elfogadása, a Nemzeti Katonai Stratégia előkészítése), továbbá a nemzetközi missziós részvétellel kapcsolatos stratégia kidolgozása tekinthető a legjelentősebb fejleménynek.

A védelmi tervezésről szóló miniszteri rendelet 2005-ben lépett életbe és részletesen szabályozta a védelmi tervezés különböző formáit (Malesic et al 2015, 66, RS Ministry of Defense 2006, 12). Elsőként a 2005-2010 közötti időszakra vonatkozó középtávú védelmi tervet készítették el ennek megfelelően. A középtávú védelmi tervek képezik az alapját a NATO (Defense Capability Planning Survey) és az EU (Headline Goal Questionnaire) felé szolgáltatandó szlovén védelmi tervezési adatoknak is (Malesic et al 2015, 67).

Malešič és szerzőtársai ugyanakkor a tervezési rendszer több hiányosságát is azonosították, így például a Védelmi Minisztérium szervezeti egységei közötti együttmüködés hiányát, a rendszer lassú alkalmazkodását és reagálását a megváltozott biztonsági környezetre és a rendelkezésre álló források változására, 
illetve az adott katonai képességek eléréséhez szükséges pénzügyi és egyéb erőforrások hibás felmérését (Malesic et al 2015, 68).

A 2009. évi stratégiai védelmi felülvizsgálat a védelmi tervezést illetően megállapította, hogy ugyan létezik a rövid, közép, és hosszú távú védelmi tervek rendszere, az egyes tervek nem kapcsolódnak egymáshoz, tartalmuk esetenként egymást átfedő, mely megnehezíti a meghatározott célok elérésének mérését és értékelését (RS Ministry of Defense 2009b, 41-43). Hosszú előkészítés után végül 2006-ban fogadták el Szlovénia új katonai doktrínáját, mely immár teljes mértékben a NATO-tagság körülményeire és az abból fakadó kötelezettségek, elvárások figyelembe vételére épült. Az új doktrína mind tartalmában, mind pedig felépítésében korszerünek tekinthető, ugyanakkor a doktrína szövegében is hivatkozott (Military Doctrine 2006,8) biztonság- és védelempolitikai alapdokumentumok, így a Nemzeti Biztonsági Stratégia és a Nemzeti Katonai Stratégia még a 2000-es évek elején kerültek elfogadásra. Az új stratégiák 2010-es évek elején történő elfogadásáig tehát nem volt biztosított az összhang a katonai doktrína és az akkorra már elavultnak tekinthető (a NATO-csatlakozást és az önkéntes haderőre való áttérést megelőzően született) koncepcionális jellegü alapdokumentumok között (Furlan 2013, 441).

A minisztérium által kezdeményezett második stratégiai védelmi felülvizsgálat (SPOR), melynek eredményeit 2009-ben hozták nyilvánosságra, azt a célt szolgálta, hogy a NATO-tagság első néhány évében szerzett tapasztalatokat felhasználva, továbbá a megváltozott pénzügyi lehetőségeket is figyelembe véve határozza meg a védelmi szektor átalakításának és fejlesztésének új irányvonalát. A dokumentum utal arra is, hogy a szlovén társadalomban egyre inkább kritikus attitüd tapasztalható a védelmi szektorral kapcsolatban, melyet a stratégiának figyelembe kell vennie, valamint a kormányzati kommunikáció és a társadalmi párbeszéd terén proaktív magatartás szükséges (RS Ministry of Defense 2009b, 53).

A SPOR következtetései szerint a megváltozott gazdasági és társadalmi feltételek mellett szükséges a kialakítandó képességekkel kapcsolatos ambíciók újraértékelése, és a rendelkezésre álló lehetőségekhez igazítása, amiről politikai konszenzust szükséges kialakítani (RS Ministry of Defense 2009b, 8-10, 52-53). Módosították a létszámra vonatkozó célkitüzést is: a 2004-es dokumentumban szereplő 14.000 helyett a szerződéses tartalékosokkal együtt 10.000 főben határozták meg a Szlovén Hadsereg tervezett létszámát (RS Ministry of Defense 2009b, 18). A stratégiai védelmi felülvizsgálat ismételten felhívta a figyelmet arra, hogy továbbra is 
szükséges a Védelmi Minisztérium adminisztratív apparátusának átalakítása. Ezen a területen a szervezeti egységek számának csökkentését, a párhuzamosságok megszüntetését, a létszám emiatt szükségessé váló csökkentését, valamint a hivatali apparátus civil és katonai komponensének szorosabb integrálását irányozta elő (RS Ministry of Defense 2009b, 47-50).

A stratégiai védelmi felülvizsgálat következtetéseit is felhasználták a szlovén haderö új hosszú távú fejlesztési és felszerelési programjának elkészítésekor, melyet 2010 novemberében fogadott el a szlovén törvényhozás. Az új terv a korábbinál lényegesen kevésbé ambiciózus célokat tüz ki az ország haderejével kapcsolatban: például a vállalt nemzetközi missziós részvételre vonatkozó felajánlások maradéktalan teljesítését 2018-ra látta elérhetőnek (ReSDPRO SV 2025, 16), távlati célként 2020-ra egy nemzetközi missziókra is telepíthető közepes gyalogsági zászlóalj harccsoport létrehozását irányozza elő (ReSDPRO SV 2025, 18). A korábbi tervek ezt a célkitüzést 2012-re látták elérhetőnek (RS Ministry of Defense 2004b). A megváltozott gazdasági helyzetet az is mutatja, hogy az új hosszú távú terv csak a 2020-as években tartja lehetségesnek, hogy a védelmi kiadások elérjék a GDP a NATO-ban elvárt 2\%-át (ReSDPRO SV 2025, 28).

Többek között a missziós részvétellel kapcsolatos politikai és társadalmi viták hatására (lásd alább) és az afganisztáni ISAF-részvétel addigi tapasztalatainak feldolgozásával is került kidolgozásra a Szlovén Köztársaság nemzetközi műveletekben és missziókban való részvételéről szóló stratégia, melyet a kormány 2009-ben fogadott el, és amely 2010. márciusában lépett életbe (Government of the RS 2010). A dokumentum általánosságban foglalkozik a missziós részvétel kérdéskörével, a katonai missziók mellett a rendőri, a civil szakértői és ezek "kombinációját" alkalmazó missziókra is kitér (Government of the RS 2010, 6).

A stratégia célul tüzi ki az integrált megközelítést (például katonai és nem katonai eszközök egyidejü felhasználását), a döntéshozatal és az előkészítés során a hatékony tárcaközi koordinációt, a kapcsolattartást a nem kormányzati stakeholderekkel (például humanitárius szervezetek), valamint a missziókkal kapcsolatos átláthatóság és társadalmi párbeszéd javítását (Government of the RS 2010, 8-11, 12-13). A stratégia a missziós részvételről szóló döntéselőkészítési és döntéshozatali folyamatot is újraszabályozta: a döntéselökészítést a Külügyminisztérium, a Belügyminisztérium és a Honvédelmi Minisztérium bevonásával végzik, a végső szót továbbra is a kormány mondja ki a részvételről, a meghozott döntésről a 
kabinetnek azonban tájékoztatnia kell a parlamentet is, valamint a törvényhozásnak évente be kell számolnia a missziós szerepvállalásról (Government of the RS 2010, $14,16)$.

A parlament ellenzéki képviselői a missziós részvételről szóló döntésben a törvényhozás jelentősebb beleszólását szerették volna elérni, és ekkor végzett közvélemény-kutatások szerint az állampolgárok többsége is azt támogatta volna, ha a parlament dönt a szlovén katonák külföldi missziós bevetéséröl (Malesic et al 2015, 84). A missziók célterülete szempontjából a stratégia a szlovén nemzeti érdekek szempontjából három legfontosabb régió között elsőként Délkelet-Európát, majd Kelet-Európát és a Kaukázust, illetve a Mediterráneumot jelöli meg. A stratégia előirányozza a missziós részvétellel kapcsolatos átláthatóság növelését is: a közvélemény támogatásának elnyerése érdekében szükségesnek tartja annak bemutatását, hogy a missziókon való részvétel a szlovén állampolgárok biztonságát is szolgálja (Government of the RS, 16).

A stratégiai dokumentumok megújításának részeként a szlovén parlament 2010-ben fogadta el a Nemzeti Biztonsági Stratégia új változatát. (RS Ministry of Defense 2011, 10). A vizsgált időszak alatt a Nemzeti Katonai Stratégia előkészítése is megtörtént, ezt azonban a szlovén kormány csak 2012 decemberében fogadta el (RS Ministry of Defense 2012, 69).

\subsubsection{A védelmi szféra nemzetközi dimenziója}

A NATO-hoz és az EU-hoz való csatlakozással Szlovénia nemzetközi missziós szerepvállalása még intenzívebbé vált. Két kis létszámú közel-keleti ENSZ missziót leszámítva Szlovénia nemzetközi katonai missziós részvételére ebben az időszakban is a NATO és kisebb részben az Európai Unió égisze alatt került sor (Malesic et al. $2015,163)$.

A missziós részvételre történő felkészülés a képességfejlesztést is nagy mértékben befolyásolta. A szlovén kormány és a parlament által 2004-ben elfogadott, 2015-ig szóló fejlesztési és felszerelési terv szerint a haderő $40 \%$-át kell alkalmassá tenni arra (megfelelő felszerelés, kiképzés, interoperabilitás megléte révén), hogy külföldi missziókra felajánlható legyen, illetve a hadseregnek képesnek kell lennie arra is, hogy a szárazföldi erők egyszerre 8\%-a vegyen részt missziós bevetésen. Ettől eltérő célkitüzést a már említett, a korábbinál lényegesen szerényebb ambíciókat 
meghatározó 2025-ig szóló hosszú távú terv sem tartalmazott (ReDPRO SV 2025, 18). A kitüzött cél az időszak végére sem teljesült, 2004 végén ez a két érték 9,5\% és 4\% volt (RS Ministry of Defense 2005, 8), míg 2010 végére -jelentős beruházások és képességfejlesztést követően- a szárazföldi haderő 30-36\%-a volt alkalmas misszióra történő kiküldésre (RS Ministry of Defense 2011, 27).

Noha a vizsgált időszakban a szlovén hadsereg nemzetközi missziós részvétele alapvetően sikeresnek minősíthető (Malesic et al 2015, 113-115), számos esetben, különösen az afganisztáni ISAF-misszió esetében a szlovén katonák kiküldése éles társadalmi és politikai viták tárgya is volt. A szlovén társadalom Vuga $(2014,360)$ alapján a bizonytalanság- és kockázatkerülő attitüdökkel jellemezhető, mely a katonaság nemzetközi missziós részvételének közvélemény általi megítélését is befolyásolta. A 2001 és 2012 között készített felmérések alapján folyamatosan igen magas (70\%-80\% feletti) volt a támogatottsága a humanitárius célú, vagy nem fegyveres misszióknak, valamint szintén a társadalom túlnyomó többsége (60-70\%) támogatta az olyan békefenntartó missziókat, melyekben a fegyverhasználat csak önvédelmi céllal engedélyezett. A harcoló alakulatok bevetését igénylö, békekikényszerítő célzatú küldetéseket azonban csak a válaszadók 30-40\%-a támogatta. Különösen a két utóbbi kategória esetében volt tapasztalható a támogatottság visszaesése 2009 és 2012 között (Vuga 2014, 369). A missziókkal kapcsolatos kockázatkerülő társadalmi attitüdöket mutatja továbbá, hogy megkérdezettek 70\%-a szerint szolgálatteljesítés közben (nem betegség, baleset vagy öngyilkosság következtében) történő halálos emberveszteséget követően az országnak ki kellene vonnia katonáit az adott misszióból. Feaver és Gelpi szerint (idézi Vuga 2014, 374) a vonatkozó amerikai adat mindössze 20\%. Érdemes ugyanakkor megjegyezni, hogy szlovén katona nemzetközi misszión szolgálatteljesítés közben még nem veszítette életét (Vuga 2014, 375).

A missziós részvétel ezen társadalmi megítélése minden bizonnyal szerepet játszott abban, hogy az egymást követő szlovén kormányok (a részvételröl eredetileg döntő Rop-kormánytól a Janša- és a Pahor-kormányig) az ISAF misszióra Afganisztánba küldött szlovén kontingensek alkalmazását illetően esetében igencsak szigorú nemzeti megkötéseket (national caveats) határoztak meg (Vuga 2014, 367-368, Jelusic 2014). Ennek ellenére az ISAF-részvétel a 2008-ban hivatalba lépő, Borut Pahor vezette kormánykoalíción belül is komoly vitákhoz vezetett, mivel ebben a kérdésben a védelmi miniszter többször szembekerült a koalíció más politikusaival. 
A miniszterelnököt és a védelmi minisztert adó szociáldemokrata párt pragmatikus álláspontot foglalt el ebben a kérdésben, azonban a kisebbik koalíciós partner Zares több alkalommal nyilvánosan is szót emelt a szlovén katonák Afganisztánból való mielőbbi hazahívása érdekében (Slovenian News Agency 2009a, 2011b). A kormánykoalíción belüli viták mellett a 2007-ben a balközép pártok támogatásával megválasztott Danilo Türk köztársasági elnök is az ISAF-részvételt kritizálók mellett foglalt állást (Jelusic 2014). Az, hogy a már említett, 2009-ben elfogadott missziós részvételre vonatkozó stratégiában jelentős szerepet kapott a társadalmi párbeszéd és a transzparencia kérdése, szintén minden bizonnyal az ISAF-részvétellel kapcsolatos ekkori politikai és társadalmi viták tanulságait is tükrözi.

Az afganisztáni szerepvállalással ellentétben a Szlovén Hadsereg a nyugat-balkáni béketámogató műveletekben való részvételét sokkal kevesebb vita övezte. A 2004 utáni időszakban a balkáni békeműveletekben való részvétel még intenzívebbé vált, a legtöbb szlovén katona a KFOR-ban teljesített szolgálatot, 2007-ben például egy gépesített gyalogsági zászlóalj és a hozzá tartozó támogató egységek kiküldésével. A vizsgált periódus minden évében a külföldön szolgáló szlovén katonák kb. 80\%-a balkáni missziókban teljesített szolgálatot (Malesic et al 2015, 83, RS Ministry of Defense 2008, 22-23). Ezen túlmenően szlovén tisztek folyamatosan teljesítettek szolgálatot a szarajevói és a szkopjei NATO-parancsnokságon (ld. pl. RS Ministry of Defense 2011, 15-16), valamint ez utóbbit 2010 folyamán egy szlovén katonatiszt vezette (RS Ministry of Defense 2012, 27). Az ország folyamatosan fenntartotta részvételét a boszniai SFOR-t 2004-ben követő, az EU égisze alatt müködő EUFOR Althea misszióban is (lásd pl. Malesic et al. 2015, 165).

Szlovénia ebben a térségben a két- és többoldalú védelmi diplomácia területén is jelentős aktivitást fejtett ki: utóbbi tekintetében egyebek mellett az amerikai részvétellel létrehozott South East Europe Clearinghouse kezdeményezés említhető meg, melynek célja a nyugat-balkáni országok euroatlanti integrációjának információcsere segítségével történő támogatása volt. Ezen kezdeményezésnek 2004 és 2011 között Szlovénia a társelnöke is volt, és keretein belül különösen Macedóniával folytatott intenzívebb együttmüködést (RS Ministry of Defense 2006, 47-48, 2012, 66-67). 


\subsubsection{A magyarázó tényezők hatásának értékelése}

A történelmi örökség hatását illetően jelen időszak megegyezett a 2000 és 2004 közötti periódus tapasztalataival: csak a pacifista attitüdök társadalomban való továbbélése kapcsán mutatható ki jugoszláv örökség szerepe. Erre az afganisztáni missziós részvétel társadalmi megítélése, valamint egy befolyásos értelmiségiek és újságírók által kezdeményezett 2010-es, az állandó hadsereg izlandi mintára történő eltörlését célzó petíció (Svete 2011) említhető jellemző példaként.

A fenyegetés-környezet hatását illetően szintén a 2000 és 2004 közötti időszakról elmondottak jellemezték ezt a periódust is: szerepük ekkor is elhanyagolható volt.

A belső politikai folyamatok hatása három területen jelentkezett: a missziós szerepvállalást övező belpolitikai viták (Malesic et al. 2015, 119-120, 129-130), a katonai beszerzésekkel kapcsolatos korrupciós ügyek, illetve azon problémák, melyek a Cottey és szerzőtársai (2002) által „második generációsnak” nevezhető intézkedésekhez köthetőek. Ez utóbbi kérdés kapcsán Branimir Furlan (2013, 444445) alapvetően a "mikromenedzsmentet" jelöli meg fö problémaként, azaz, hogy olyan alacsony szintü, vagy szakmai döntések meghozatala is a védelmi miniszter vagy a VM apparátusa által történik, mely más demokratikus országokban a vezérkar vagy a katonai vezetés feladata. Mindez pedig negatívan érinti a hadsereg hatékony feladat-ellátását, és végső soron a demokratikus civil-katonai kapcsolatokat is negatívan befolyásolja. Jelusic (2014) és Grizold (2014) értékelése szerint az időszak egyik fő problémáját az jelentette, hogy a Védelmi Minisztérium apparátusának átalakítása jóval lassabban haladt, mint a hadsereg modernizálása és professzionalizálása. A minisztériumi apparátus elégtelen müködése pedig a demokratikus kontroll hatékonyságát is negatívan befolyásolhatja.

Malesic (2017) mint fentebb említettem arra mutat rá, hogy a katonai beszerzésekkel kapcsolatos korrupciós botrányok föszereplői ugyan a politikai osztály tagjai, ezen botrányok mégis a hadsereg, mint intézmény társadalmi megítélését érintik negatívan, ezáltal a hadsereg ezen botrányok egyfajta ,áldozataként” értelmezhető.

A nemzetközi szereplők, konkrétan a NATO erős befolyása ezen a politikaterületen a csatlakozás után némiképp csökkent, ugyanakkor nyilvánvalóan nem szünt meg, hiszen például a képességfejlesztés a missziós részvétel érdekében és annak figyelembe vételével történt, valamint a védelmi tervezés rendszerét is a NATO-hoz igazítva müködtették. 


\subsection{A szlovén eset föbb sajátosságai}

Az 1980-as évek során a Jugoszláv Néphadsereg (JNH) társadalmi elfogadottsága megrendült az akkori Szlovén Szocialista Köztársaságban, és a szövetségi hadsereggel kapcsolatos ellenérzések fokozatosan összekapcsolódtak a függetlenségi és demokratizációs törekvésekkel is. A JNH-val kapcsolatos kritikák és ellenérzések emiatt az évtized végére a társadalom egészére is jellemzők voltak, már nem csupán egy pacifista vagy újbaloldali ifjúsági ellenkultúra képviselte őket (Gow 1992, 78 88). A szlovén társadalmat már korábban is jellemezte a pacifista értékrendszer, valamint a fegyveres erők és a katonai hivatás alacsony társadalmi presztízse (Vuga 2014, 262). A JNH-val szembeni társadalmi ellenérzések egyik következménye, hogy a független szlovén haderő felállításakor bizonyos kérdésekben (például a lelkiismereti szolgálatmegtagadás európai összehasonlításban is igen megengedö szabályozása) éreztetni kívánták a jugoszláv gyakorlattal való éles szakítást (Jelusic 2002, 114-115).

A rendszerváltás kezdetén a politikai erők és a társadalom egy része Szlovénia demilitarizálásáért szállt síkra, a jugoszláviai helyzet eszkalálódása és a JNH jelentette fenyegetés hatására viszont a társadalom elfogadta, hogy a függetlenség kivívásához önálló fegyveres erőkre is szükség lehet. (Szilágyi 2002, 23-24). A rövid 1991-es függetlenségi háború azt bizonyította, hogy nem voltak reálisak a demilitarizációra vonatkozó elképzelések (Szilágyi 2002, 97), és a Területvédelmi Erők szerepe a függetlenség kivívásában segített - legalább átmenetileg újraértékelni a honvédelem ügyét egy alapvetően hadseregellenes és pacifista társadalomban (Malesic és Jelusic 2005, 211-212).

Az új szlovén haderő döntően a korábbi Területvédelmi Erők tagjaiból, a függetlenségi konfliktusban részt vevő civilekből, illetve a JNH szlovéniai, alacsonyabb rendfokozatú tartalékos tisztjeiből jött létre. A JNH szlovén származású tisztjei közül igen kevés - a tábornokok közül például egy sem - került át az új szlovén hadseregbe (Bebler 1996, 208-210, Vankovska és Wiberg 2003, 173-174, Juhász 1999, 241). Az ekkoriban pozícióba került katonai vezetők, az ún. „,heroikus parancsnokok" a kilencvenes évek végéig jelentős szerepet játszottak a szlovén hadseregben, noha hivatásos katonai múltjuk és szaktudásuk csak korlátozottan vagy egyáltalán nem volt (Kotnik és Kopac 2002, 152).

A 1991-es tíznapos háború és az abban aratott szlovén győzelem a fiatal állam egyik 
legitimációs bázisává, „eredetmítoszává” vált, és a rövid konfliktus tapasztalatai a kilencvenes években nagy hatást gyakoroltak a formálódó szlovén haderöre, és az akkor folyó védelempolitikai vitákra (Malesic és Jelusic 2005, 211-212).

A demokratikus rendszerváltás és a függetlenség elnyerése után a demokratikus kontroll intézményrendszerét a nemzetközi gyakorlatnak megfelelően alakították ki, ugyanakkor történelmi okok és a haderô létrehozásának módja miatt a védelmi szférát a civilek dominanciája jellemezte (Furlan 2013, 443). A fegyveres erők már említett erőteljes „civilesedése” részben elősegítette a demokratikus civil-katonai kapcsolatok kialakulását, mivel lehetetlenné tette egy „katonai lobbi” létrejöttét, rendkívül negatívan hatott ugyanakkor a fegyveres erők professzionalizációjára, mely utóbbi különösen az évtized második felétől jelentett problémát. A szilárd civil és demokratikus kontroll kiépítése nem jelentette azonban azt, hogy a hadsereg teljességgel mentessé vált volna a pártpolitikától (Bebler 1996, 209-210).

Annak ellenére, hogy a kilencvenes évek elején a haderő demokratikus kontrolljának intézményrendszere kiépült, annak müködtetése nem volt problémamentes. A demokratikus civil-katonai kapcsolatok kialakítását nehezítette a szakterület erős átpolitizáltsága, a jogi környezet sokáig tisztázatlan volta, valamint, hogy a politikusok igyekeztek a katonai vezetők egy részét is az ekkor folyó, a honvédelemmel kapcsolatos hatásköri-politikai vitákba "bevonni". A katonai kinevezésekben sok esetben a politikai lojalitás a szakértelemnél nagyobb szerepet játszott, a hadsereggel kapcsolatos politikai botrányok (pl. a Moris-ügy) pedig a közvélemény szemében is rontották a fegyveres erők megítélését (Malesic 2006, 146, Bebler 1996, 206-210). Ezek a tendenciák csak a 2000-es évek elejétől szorultak háttérbe a fegyveres erők professzionalizálására irányuló reformok felgyorsítása miatt. A kilencvenes évekre különösen jellemző volt, de a vizsgált időszak egészét végig kísérte, hogy a fegyveres erők parlamenti kontrolljának müködését a szaktudás és a tapasztalat hiánya, a szükséges támogató személyzet hiánya vagy korlátozott volta, valamint az nehezítette, hogy a bizottsági tagok döntéseiben a pártfegyelem a szakmai szempontoknál fontosabb szerepet játszott. (Malesic és Jelusic 2005, 216, Malesic et al. 2015, 62-63, 70).

A szlovén politikai elitben 1994-re konszenzus jött létre a tekintetben, hogy az ország a jövőben a NATO-tagja kíván lenni, azonban a politikai vezetés 1997-ig leginkább csak egyoldalúan bízhatott abban, hogy az ország mindenképp bekerül a NATO kibővítésének első körébe. A haderő reformja és NATO-kompatibilissé tétele terén, 
különösen 1997-ig megmutatkozó elmaradások az egyik, a helyi elemzők és megfigyelők által akkor nem kellően felismert okát képezték annak, hogy Szlovénia ekkor még nem kapott meghívást az atlanti szövetségbe. (Szilágyi 2002, 81-83).

A kilencvenes évek második felét a honvédelem területén a szakpolitikai folytonosság hiánya mellett az jellemezte, hogy egyfajta „versengés” volt megfigyelhető a svájci mintára épülő milícia-szerü területvédelmi koncepció, és a gyorsan mozgósítható, hivatásos, nemzetközi és NATO feladatokra is felkészített haderő modellje között (Keridis és Perry 2004, 9). Megítélésem szerint ennek a szakmai vitának, az utóbbi modell ,javára” legkésőbb a védelmi tárcát 2000 és 2004 között vezető Anton Grizold miniszter hivatali ideje alatt elindított reformokkal került pont a végére. (ld. pl. RS Ministry of Defense 2009b, 9).

A hivatásos katonai szakma a honvédelemmel kapcsolatos szakpolitikai vitákban nem jelent meg önálló tényezőként, érdekérvényesítő képessége csekély volt és mindvégig politikailag alárendelt szerepet játszott. Ezen jelenség jellemző példája volt az önkéntes haderőre való átállás időpontja és ütemezése kapcsán folyó szakmai és politikai vita a 2000-es évek elején (Jelusic 2017, Malesic 2017, Bebler 2004, 128-130, Svete és Jelusic 2009, 8).

Bár a társadalmi bizalom a szlovén fegyveres erőkben mindvégig magas volt, de ez nem párosult a katonai szakma társadalmi presztízsével, valamint azzal, hogy az állampolgárok részt is kívántak volna venni a honvédelemben. Erre utal a sorkatonaság intézményének válságba kerülése a 2000-es évek elejére és a lelkiismereti szolgálatmegtagadás magas aránya. (Bebler 2000, 147, Jelusic 2005, 83). A kétezres években egyes missziós szerepvállalások (különösen az afganisztáni) jelentős társadalmi elutasítottsága, valamint az a befolyásos értelmiségiek és újságírók által kezdeményezett 2010-es petíció, mely az állandó hadsereg izlandi mintára történő eltörlését kívánta volna elérni (Svete 2011, Malesic et al 2015, 118, 121-122), azt mutatja, hogy a hadseregellenes és pacifista attitüdök továbbra is erősen jelen vannak a szlovén társadalomban. Malesic (2017) arra mutat rá, hogy a kétezres évek korrupciós botrányainak (különösen a Patria-ügy) főszereplői a politikai osztály tagjai és civil köztisztviselők voltak, ezen botrányok mégis a hadsereg társadalmi megítélését érintették negatívan.

A vizsgált időszak végére lezárult a hivatásos hadseregre történő átállás folyamata (a strukturális professzionalizáció), ugyanakkor a haderő funkcionális professzionalizációja (a fegyveres erők müködésének professzionálisabbá tétele), 
továbbra is folyamatban van. Ezen túlmenően, a hadseregénél jóval lassabban haladt a minisztérium apparátusának átalakítása is. A teljes időszak alatt, különböző okokból, problémát jelentett a minisztérium katonai és civil komponense, illetve a minisztérium és a katonai vezetés közötti együttmüködés nem elegendő mértéke vagy minősége (Grizold 2014, Jelusic 2014).

A vizsgált húsz éves periódus alatt két alkalommal (2000-2004, 2008-2011) szakértő vagy szakértő hátterü miniszter vezette a védelmi tárcát. A pártpolitikus és a szakértő miniszterek vezetési stílusa között hangsúlykülönbségek is megfigyelhetőek voltak: a pártpolitikusok a minisztérium vezetése során főként a civil köztisztviselői apparátusra támaszkodtak, míg a szakértő hátterü miniszterek szorosabb együttmüködésre törekedtek a vezérkarral (ti. a vezérkari főnök a törvény szerint a miniszter katonai tanácsadója) az általuk tervezett reformok sikeres megvalósítása érdekében (Jelusic 2014). Furlan $(2013,445)$ alapján a szlovén eset arra is példát szolgáltathat, hogy a civil kontroll túl magas szintje, vagy túl nagy mértéke (a korábban már említett „mikromenedzsment” problémája) negatívan hathat a stabil és demokratikus civil-katonai kapcsolatok kialakítására, valamint a hadsereg hatékony feladat-ellátását is negatívan befolyásolhatja.

A vizsgált magyarázó tényezők hatását Szlovénia esetében a 6. táblázat tartalmazza. Mivel a tíznapos konfliktust leszámítva az ország kimaradt a délszláv háborúkból, megítélésem szerint a biztonsági fenyegetések szerepe csak az első két periódusban, különösképpen pedig a boszniai és a horvátországi háború 1995-ös lezárásáig mutatható ki (Vankovska 1995, 219-220). A kétezres évekre a közvetlen biztonsági fenyegetések háttérbe szorultak, ami azzal is illusztrálható, hogy az ebben az évtizedben született stratégiai dokumentumok (például a nemzeti biztonság stratégia) a nem konvencionális fenyegetéseket helyezték előtérbe, valamint a társadalom is elsősorban ezeket érzékelte releváns fenyegetésként (ld. pl. Kotnik és Kopac 2002, 156-157 és ReSNV 2001, 3.2-3.3. pont).

A történelmi örökség, különösen a jugoszláv múlt és az 1991-es háború tapasztalatai formájában az első periódusban játszott érdemi szerepet, utána ez a tényező némiképp háttérbe szorult, azonban például a pacifista társadalmi attitüdök továbbélése miatt később sem tünt el teljesen (Jelusic 2002, 112-113, Svete 2011, Bebler és Jazbec 2010, 55). 
Az államépítéssel járó kihívások és a honvédelmet, mint szakpolitikai területet övező éles viták (pl. az 1990 és 1994 közötti védelmi miniszter, Janez Janša személyéhez kapcsolódó politikai ügyek, illetve a miniszter és az államfő jogi és hatásköri vitái) miatt az első periódusban egyértelmüen a belsö politikai folyamatok játszották a vezető szerepet a szlovéniai civil-katonai kapcsolatok alakulásában (Malesic 2006, 131-132, 143, Bebler 1996, 209-210).

A belső politikai tendenciák hatása a következő (1994 és 2000 közötti) periódusban is fontos maradt: a védelmi tárca élén történt gyakori miniszterváltások és a szakpolitikai folytonosság hiánya megnehezítették a stratégiai tervezést, ami negatív hatással járt a NATO-csatlakozásra történő felkészülés szempontjából (Malesic 2017, Jelusic 2002, 118-119, Vankovska és Wiberg 2003, 177-178).

Ettől függetlenül az 1994 és 2000 közötti időszakban mutatható ki először érdemben a nemzetközi szervezetek (közöttük leginkább a NATO) befolyása is, különösen az időszak vége felé, amikor a NATO-tagságra való felkészülés felgyorsult és az ország 1999-töl a NATO Csatlakozási Akcióterv (MAP) tagja lett.

A NATO hatása az általam vizsgált területen a harmadik, 2000 és 2004 közötti időszakban volt a legerősebb (Kopac 2017). Ekkor megítélésem szerint „találkozott” a NATO-tagság feltételeinek teljesítésére irányuló belső politikai akarat (szakértő miniszter kinevezése, szakpolitikai folytonosság, tervszerü szakpolitikai döntéshozatal), a NATO-tagság belátható és hiteles perspektívájával, valamint a tagságra való felkészülés-felkészítés strukturált és intézményesített formáinak (pl. a MAP) meglétével (Malesic et al. 2015, 12-14, Kopac 2017).

A NATO erős hatása ezen a szakpolitikai területen a csatlakozás után némiképp csökkent, ugyanakkor nyilvánvalóan nem szünt meg, hiszen például a képességfejlesztés elsődlegesen a missziós részvétel érdekében és annak figyelembe vételével történt, valamint a védelmi tervezés rendszerét is a NATO-hoz igazítva müködtették.

Az afganisztáni missziós részvételt övező társadalmi-politikai viták (Malesic et al. 2015, 119-120, 129-130), és a Patria-ügy (Furlan 2013, 448-449), viszont arra mutatnak rá, hogy a vizsgált területen a belső politikai folyamatoknak továbbra is érdemi szerepe volt. 


\section{6. táblázat: A vizsgált magyarázó tényezők hatása Szlovénia esetében}

\begin{tabular}{|c|c|c|c|c|}
\hline $\begin{array}{c}\text { Periódus és } \\
\text { jellemzö példák }\end{array}$ & $\begin{array}{c}\text { TÖRTÉNELMI } \\
\text { ÖRÖKSÉG }\end{array}$ & $\begin{array}{l}\text { FENYEGETÉS- } \\
\text { PERCEPCIÓK }\end{array}$ & $\begin{array}{l}\text { BELSŐ POLITIKAI } \\
\text { FOLYAMATOK }\end{array}$ & NEMZETKÖZI SZEREPLŐK \\
\hline \multirow[b]{2}{*}{ 1991-1994 } & Érdemi & Kimutatható & Meghatározó & Kimutatható \\
\hline & $\begin{array}{l}\text { 1991-es háború } \\
\text { tapasztalatai } \\
\text { Jugoszláv múlttal való } \\
\text { éles szakítás } \\
\text { Területvédelem } \\
\text { intézményi öröksége }\end{array}$ & $\begin{array}{l}\text { Horvátországi és bosz- } \\
\text { niai háború, instabilitás } \\
\text { a szomszédságban } \\
\text { ENSZ-fegyverembargó } \\
\text { hatásai }\end{array}$ & $\begin{array}{l}\text { Hatásköri viták a } \\
\text { védelmi miniszter és } \\
\text { köztársasági elnök között } \\
\text { Moris-ügy } \\
\text { Embargó megsértésével } \\
\text { kapcsolatos botrányok }\end{array}$ & $\begin{array}{l}\text { ENSZ fegyverembargó } \\
\text { hatásai } \\
\text { Biztonságpolitikai } \\
\text { „útkeresés” } \\
\text { Nincs NATO tagsági } \\
\text { perspektíva }\end{array}$ \\
\hline \multirow[b]{2}{*}{$1994-2000$} & Kimutatható & Kimutatható & Meghatározó & Kimutatható \\
\hline & $\begin{array}{l}\text { Területvédelem } \\
\text { intézményi öröksége } \\
\text { 1995-ös katonai } \\
\text { doktrína }\end{array}$ & $\begin{array}{l}\text { Horvátországi és bosz- } \\
\text { niai háború 1995-ig } \\
\text { Ezt követően a konven- } \\
\text { cionális fenyegetések } \\
\text { háttérbe szorulása }\end{array}$ & $\begin{array}{l}\text { Gyakori } \\
\text { miniszterváltások } \\
\text { Fejlesztési prioritások } \\
\text { gyakori változtatása } \\
\text { Stratégiai tervezés } \\
\text { hiánya }\end{array}$ & $\begin{array}{l}\text { NATO tagsági perspektíva } \\
\text { a kilencvenes évek } \\
\text { második felétől } \\
\text { NATO MAP részvétel } \\
\text { 1999-től }\end{array}$ \\
\hline \multirow[b]{2}{*}{$2000-2004$} & Kimutatható & Elhanyagolható & Érdemi & Meghatározó \\
\hline & $\begin{array}{l}\text { Pacifista társadalmi } \\
\text { attitüdök: vita a NATO } \\
\text { csatlakozásról }\end{array}$ & $\begin{array}{l}\text { Nem konvencionális } \\
\text { fenyegetések }\end{array}$ & $\begin{array}{l}\text { Viták a sorkötelezettség } \\
\text { megszüntetéséről } \\
\text { Reformok a NATO- } \\
\text { csatlakozás érdekében }\end{array}$ & $\begin{array}{l}\text { Részvétel a NATO MAP- } \\
\text { ban és csatlakozási } \\
\text { folyamat } \\
\text { Magas szintű személyes } \\
\text { kapcsolatok szlovén és } \\
\text { NATO szereplők között }\end{array}$ \\
\hline \multirow[b]{2}{*}{ 2004-2011 } & Kimutatható & Elhanyagolható & Érdemi & Érdemi \\
\hline & $\begin{array}{l}\text { Pacifista társadalmi } \\
\text { attitüdök: missziós } \\
\text { szerepvállalás } \\
\text { megítélése }\end{array}$ & $\begin{array}{l}\text { Nem konvencionális } \\
\text { fenyegetések }\end{array}$ & $\begin{array}{l}\text { Viták a missziós } \\
\text { szerepvállalásról } \\
\text { Patria-ügy } \\
\text { Védelmi kiadás- } \\
\text { csökkentések }\end{array}$ & $\begin{array}{l}\text { NATO tervezési rendszer } \\
\text { bevezetése } \\
\text { Fokozottabb részvétel } \\
\text { NATO és EU missziókban }\end{array}$ \\
\hline
\end{tabular}

Forrás: saját szerkesztés 


\section{Horvátország - Demokrácia: ütközetben eltünt?}

\subsection{A horvátországi rendszerváltás és az önálló horvát hadsereg létrejötte}

A rendszerváltás és a hadsereg létrejöttének tárgyalását megelőzően hasznosnak tartom röviden áttekinteni a pártállami rendszer utolsó időszakának főbb jellemzőit Horvátországban, mivel megítélésem szerint ez hozzájárul az 1989-1990-es és ezt követő események jobb megértéséhez. Mint említettem, az ún. „horvát tavasz” mozgalom bukását követően az 1971-ben hivatalba lépő új horvátországi kommunista vezetés igen kiterjedt, az 1968 utáni csehszlovákiai helyzethez hasonló „normalizációs” politikát folytatott, melynek keretében jelentős tisztogatások történtek az állami és társadalmi élet (kormányzat, akadémiai szféra, média, állami vállalatok) számos területén. Ennek a politikának a végrehajtásában számos horvátországi szerb származású pártvezető, például Dušan Dragosavac és Milutin Baltić is részt vett (Meier 1999, 17-19). Az 1971 utáni horvát kommunista vezetés később is meglehetősen keményvonalas, ortodox kommunista irányvonalat képviselt, és az egyebek mellett a kulturális és tudományos életben is tapasztalható „szigor” csak az 1980-as évek közepétől és lassan oldódott. Ennek a keményvonalas irányvonalnak fontos részét képezte a nacionalista, vagy nacionalistának tartott megnyilvánulások elleni fellépés (Cohen 1997, 71-72, Pickering és Baskin 2008, 524-525, Tanner 2001, 204-206, 221-222, Meier 1999, 129-131).

Több szerző (pl. Tanner, 2001, 221-223, Meier 1999, 128-129, 141) azon a véleményen van, hogy a horvát nacionalizmus 1989-1990-től tapasztalható felfokozódása nem csak Milosevics nagyszerb nacionalista programjára volt reakció, hanem a fentebb említett, „normalizációs” politikára is, melyet a Horvát Kommunista Szövetség vezetése és részben szerb, részben horvát származású funkcionáriusai folytattak 1971 és az 1980-as évek második fele között.

Ebben a „nacionalista reneszánszban” a külföldön élő horvát diaszpóra egy része is jelentős szerepet játszott. Számos, 1990-től a HDZ (Hrvatska demokratska zajednica, Horvát Demokratikus Közösség) pártban, vagy a Tudjman-éra kormányaiban jelentős szerepet játszott személyiség a horvát nacionalista emigráció soraiból került ki. Gojko Šušak, Tudjman későbbi nagy hatalmú védelmi minisztere például a hatvanas évek végén, gazdasági okok miatt vándorolt ki az akkori Bosznia-Hercegovinából Kanadába (Hockenos 2003, 27-30, 31-32). Šušak egyébként a hercegovinai Siroki 
Brijeg (a titói időszak alatt Listica) településről származott, mely a második világháború alatt az usztasa mozgalom egyik fellegvára volt (Hockenos 2003, 33-34, Vankovska és Wiberg 2003, 223).

Franjo Tudjman, aki partizánparancsnokból és a JNH tábornokából előbb kommunista történésszé, majd a hetvenes-nyolcvanas években nacionalista disszidenssé vált, először 1987-ben látogatott Kanadába, majd a következő két évben több észak-amerikai látogatása során jó kapcsolatot alakított ki az ottani nacionalista emigráció számos képviselőjével. A horvát diaszpóra pénzügyi és szervezési támogatására Tudjman nem csupán az 1990. évi első szabad választások során, hanem később a horvátországi háború időszakában is támaszkodott (Hockenos 2003, 53-55, 80-102).

Tudjman és a HDZ választási győzelmét az első horvátországi szabad választáson a külföldről kapott kampánytámogatások, és a párt jobb szervezettsége, valamint a többi ellenzéki párt szervezetlensége és széttagoltsága mellett az magyarázta leginkább, hogy az 1990-es választást leginkább a Jugoszláviához való viszony kérdése dominálta. Ebben a kérdésben pedig a HDZ egyértelműen a konföderáció, vagy az állami függetlenség mellett szállt síkra (Tanner 2001, 223, Cohen 1997, 77 80). Mivel az alkotmányos rendszer kialakítását az utolsó pártállami vezetés a szabad választások utánra hagyta, valamint kétfordulós, egyéni kerületekre épülő választási rendszert alakított ki - részben arra számítva, hogy ez lehetővé teszi számára a hatalmon maradást - , a HDZ a szavazatok 40\%-ával a parlamenti mandátumok több mint kétharmadát meg tudta szerezni, és a gyakorlatban egyedül dönthetett az alkotmányozást illető kérdésekben is (Ramet 2010, 266, Meier 1999, 134, Tanner 2001, 227-228, Cular 2000, 32-33).

Felmerül a kérdés, hogy az 1990 áprilisi választásokon hatalomra került HDZkormányzat, illetve maga Tudjman bizonyos intézkedései - a tervezett alkotmányban a szerbek államalkotó státuszának megvonása, a cirill ábécé hivatalos státuszának megszüntetése, majd később a nagyarányú személycserék egyebek mellett a rendőrségen belül, az úgynevezett „horvátosítás” (Cohen 1997, 80-82, Tanner 2001, 229-232, Juhász 1999, 213-214, 226-227) - mennyiben járultak hozzá a krajinai szerb szeparatista mozgalom kialakulásához. Tudjman fenti intézkedései és retorikája kétségtelenül nem javították a helyzetet: Hockenos (2003, 55-57) szerint a diaszpórából érkezett HDZ-politikusok voltak horvát oldalról a leginkább felelősek ebben az időszakban a horvát-szerb etnikai kapcsolatok elmérgesítésében. 
Meier (1999, 150-151) arra mutat rá, hogy a horvát államfő legjelentősebb politikai hibája abban állt, hogy nem tett viszonylag könnyen megvalósítható engedményeket (pl. az államalkotó nép státusz megtartása) a horvátországi szerbség felé abban az időszakban, amikor ez a közösség még nem volt egységes, és a relatíve mérsékelt politikusait (pl. Jovan Rašković) még nem marginalizálták teljesen a teljesen Milosevics irányítása alatt álló radikális aktivisták.

Véleményem szerint ugyanakkor ezzel kapcsolatban megjegyzendő, hogy egyes források szerint (Tanner 2001, 225-226, Central Intelligence Agency 2003, 25-27), a horvátországi szerbek felfegyverzése, a szerb köztársasági állambiztonság (SDB/RDB) közremüködésével már Tudjman hatalomra kerülése előtt megkezdődött, és a horvát nacionalizmus újjáéledésének veszélyével, és a horvátországi szerbek diszkriminációjával kapcsolatos üzenetek szintén Tudjman hatalomra jutását megelőzően is jelen voltak már a belgrádi sajtóban (ld. pl. Tanner 2001, 218). Ezen túlmenően maga a nagyszerb nacionalista politikai program alapvető célkitüzése - szoros föderáció vagy a jugoszláv állam felbomlása esetén a tagköztársasági határok újrarajzolása - ellentétben állt az alapvető horvát célokkal (állami függetlenség vagy Jugoszlávia laza konföderációvá alakítása). Ez utóbbi ellentét kezdettől fogva magában hordozta a konfliktus veszélyét (ld. pl. Tatalovic 1996, 169, Tanner 2001, 218-219, Juhász 1999, 222-223). A fentiek miatt véleményem szerint a HDZ-kormány 1990 tavaszi és nyári intézkedései inkább ürügyet, és nem a tényleges indítóokot képezték a krajinai szerbek mozgalmának intenzifikálódásához (lásd még Vankovska és Wiberg 2003, 202).

A horvátországi szerbek és horvátok közötti etnikai kapcsolatok fokozatos elmérgesedése mellett az új kormány az önálló védelmi erő létrehozására irányuló lépéseit az is jelentősen befolyásolta, hogy a szövetségi hatóságok a Területvédelem fegyvereit Horvátországban is bevonták, ugyanakkor Szlovéniával ellentétben Horvátországban ez a „leszerelés” teljesen végbement. Ezért új fegyveres erők kialakításakor a horvát kormány kezdetben elsődlegesen a rendőrségre támaszkodott. A horvátországi szerbeknek a rendőrség állományában meglévő felülreprezentáltsága miatt (20\%, szemben a teljes lakosságon belüli 12\%-os arányukkal), az első lépések arra irányultak, hogy új rendőrkapitányságok létrehozásával és új rendőrök toborzásával csökkentsék a rendőrségen belül a szerbek arányát (Vankovska 2002, 57). Ezen túlmenően új, katonai jellegü különleges rendőri egységeket alakítottak ki, valamint megkezdték a rendőrség tartalékos egységeinek feltöltését is. Az ennek 
megoldására tett intézkedések ellenére egészen 1991 őszéig a fegyverhiány is akut problémát jelentett a horvátok számára (Juhász 1999, 226, Central Intelligence Agency 2002, 83, Central Intelligence Agency 2003, 35, 53, Vego 1993, 203).

A különleges rendőri egységeket 1990. július-augusztusában állították fel, és az év végére körülbelül 3.000 fő állt ilyen egységekben a horvát köztársasági belügyminisztérium ellenőrzése alatt, akiket részben a külföldröl vásárolt fegyverekkel (lásd alább) szereltek fel (Central Intelligence Agency 2003, 35-36).

A tartalékos rendőri erők, melyeket 1990 öszén kezdtek megszervezni, 1990 végén körülbelül 7.000, 1991 májusában körülbelül 10.000 föt számlálhattak, ugyanakkor egy részüknek ekkor még nem volt semmiféle fegyverük (Central Intelligence Agency 2003, 36-37). A rendőrség mellett a köztársasági védelmi minisztérium is bekapcsolódott a horvát védelmi erő kialakításába, miután 1990. augusztus 24-én Martin Špegelj tábornokot, a JNH Horvátországot is magában foglaló V. katonai körzetének korábbi parancsnokát nevezte ki Tudjman a tárca élére. Špegelj kezdettől fogva a külföldről történő fegyvervásárlást tekintette az általa vezetett minisztérium egyik fö feladatának, és ezzel párhuzamosan, a köztársasági védelmi minisztérium égisze alatt megkezdte önkéntes egységek szervezését is (Central Intelligence Agency 2003, 37-38). Špegelj és a horvát kormány több forrásból, egyebek mellett Magyarországról, a korábbi NDK arzenáljából, illetve a közel- és távol-keleti piacról (pl. Szingapúr) is kísérelt meg fegyvereket vásárolni. 1990 októberében például a miniszter Budapestre látogatott, ahol megbeszéléseket folytatott a magyar kormány és a Technika külkereskedelmi vállalat illetékeseivel, és sikerült is megállapodást kötnie többek között 30.000 Kalasnyikov gépkarabély leszállításáról. A szerződésben szereplő fegyverek közül azonban csak kb. 10.000 jutott el ténylegesen Horvátországba, 1991 nyaráig külföldi forrásokból összesen kb. 20-30.000 kézifegyvert tudott a horvát kormányzat beszerezni (Central Intelligence Agency 2003, 53, Tanner 2001, 234-235, Vego 1993, 203-204). A fegyverbeszerzésekben kezdettől fogva támaszkodtak a horvát diaszpóra által gyüjtött pénzügyi forrásokra is (Hockenos 2003, 81-90). Noha 1990 végére a jugoszláv katonai elhárítás már jelentős mennyiségű információt gyüjtött a horvát fegyverszállításokról, és ki is dolgozták a horvát egységek lefegyverzésére, valamint Špegelj és munkatársai letartóztatására irányuló akció részleteit, 1990 végéig erre nem kaptak engedélyt sem Kadijevićtől, sem pedig az államelnökségtől (Central Intelligence Agency 2003, 55 $56,58-60)$. 
Mint a 4. fejezetben említettem, az államelnökség később, 1991 januárjában, majd 1991 márciusában sem adott felhatalmazást a szövetségi hadseregnek, illetve védelmi minisztériumnak a horvát fegyveres alakulatok leszerelésére, annak ellenére sem, hogy a hadsereg január végén a Špegelj tevékenységéről készített rejtett kamerás felvételek nyilvánosságra hozatalával igyekezett az elnökségre és a közvéleményre is nyomást gyakorolni ennek érdekében (Central Intelligence Agency 2002, 86-88, Silber és Little 1996, 158-160).

Valószínúleg tudomást szerezve a Horvátország ellen tervezett szövetségi beavatkozásról, Špegelj a Legfelsőbb Államtanács december eleji ülésén ismertette először tervét a horvát államfönek a tagköztársaság területén található JNH-laktanyák blokád alá vételéről. Špegelj érvelése szerint, ha az eddig megalakított és felszerelt horvát fegyveres egységeket erre a célra használnák fel, továbbá megszakítanák az érintett laktanyák kommunikációs kapcsolatait és közüzemi ellátását, a túlnyomórészt gyengén kiképzett sorkatonák által védett laktanyák nem lennének képesek érdemi ellenállást kifejteni, és a szabad elvonulás fejében a horvát kormánykatonák jelentős mennyiségü fegyvert tudnának zsákmányolni. Tudjman és a kormány többi tagja azonban a tervet túl kockázatosnak tartva elutasították, egyebek mellett azzal érvelve, hogy egy ilyen lépés esetén Horvátország a nemzetközi közösség jóindulatát is elveszítené (Central Intelligence Agency 2002, 87, Central Intelligence Agency 2003, 60, Silber és Little 1996, 148-149). A Špegelj és Tudjman közötti viták a követendő védelmi lépéseket illetően a miniszter teljes, 1991 júliusáig tartó hivatali idejét jellemezték.

Az 1990 decemberében elfogadott új horvát alkotmány konkrétan a fegyveres erőkről mindössze két mondatban rendelkezik: a 7. cikk szerint a Horvát Köztársaság fegyveres erejének célja az állam függetlenségének és szuverenitásának védelme, valamint, hogy a fegyveres erök müködését további törvény szabályozza (Ustav Republike Hrvatske 1990, Članak 7). A francia mintájú félelnöki rendszert bevezető új alkotmány azonban igen széles jogköröket biztosított az államfő számára védelmi és biztonsági területen is. Az alkotmány 100. cikke szerint a köztársasági elnök a hadsereg főparancsnoka, „a törvényes elöírásoknak megfelelően” kinevezi és felmenti a katonai vezetőket, valamint a Nemzetvédelmi Tanács tagjait. A 101. cikk szerint háború, közvetlen háborús veszély, az állam függetlensége vagy egysége elleni fenyegetés esetén, valamint, ha az államszervezet normális müködése nem biztosított, a köztársasági elnök törvényerejü rendeleteket bocsáthat ki, melyeket a 
parlamentnek utólag kell jóváhagynia. Az elnök feladatainak ellátásához kinevezheti és felmentheti az Elnöki Tanács tagjait, illetve saját hatáskörében egyéb tanácsadó és döntéselőkészítő testületeket hozhat létre (Ustav Republike Hrvatske 1990, Članak 100-101, Lukic 2008, 189-190). Az alkotmány 106. cikke szerint pedig az elnök hatáskörének gyakorlása érdekében tanácsadó testületeket hozhat létre, melynek tagjait saját maga nevezi ki és menti fel (Ustav Republike Hrvatske 1990, Članak 106). Az alkotmány által biztosított széles elnöki jogkörök, különösen azok „kiterjesztő” értelmezése volt az egyik eszköz, mely lehetővé tette Tudjman számára a fegyveres erők feletti ellenőrzés egyszemélyi formáinak kialakítását. Ezáltal az államfő nem csak a fegyveres erök parlamenti felügyeletét „kerülte meg”, hanem az általa alakított elnöki tanácsadó testületek sok esetben a kormány szerepét is átvették a katonai-védelmi döntéshozatalban (Ramet 2010, 259-260, Edmunds 2003, 14-15, Edmunds 2007, 54-55).

A köztársasági elnök 1991. április 10-i rendeletével (és a horvát parlament által április 18-án elfogadott törvény alapján) alakult meg a Nemzeti Gárda (Zbor Narodne Garde, ZNG), mely az első önálló, a rendörségtől formálisan független fegyveres szervezet volt Horvátországban. Jogi okokból az új testület a köztársasági Belügyminisztérium alá tartozott, és feladataiként a határok és az államterület védelmét, a terrorista cselekmények elleni fellépést, valamint a kritikus infrastruktúra, például kikötők és repülőterek védelmét jelölték meg. A gyakorlatban a ZNG a köztársasági Védelmi Minisztérium irányítása alatt állt, és a jövőbeli horvát hadsereg „alapköveként” számoltak vele (Vego 1993, 204, Central Intelligence Agency 2003, 45-46, Vankovska 2002, 57).

Kezdetben a ZNG a rendőrség keretében már felállított különleges rendőri egységek „átvételével” jött létre, egy különleges müveleti zászlóaljat pedig az emigrációból hazatért, korábban a francia idegenlégióban szolgált horvátok részvételével alakítottak ki (Central Intelligence Agency 2003, 45). A Nemzeti Gárda első egységeinek hivatalos eskütételére 1991. május 28-án került sor Zágrábban, mely dátum azóta is a horvát fegyveres erők napja (Ministarstvo obrane RH 2016, 22).

Noha Szlovénia és Horvátország formálisan összehangolták a függetlenség elnyerésére irányuló lépéseiket, kezdettől fogva nyilvánvaló volt, hogy Horvátország Szlovéniához képest sokkal inkább „el volt maradva” a függetlenség valós életbe léptetéséhez szükséges jogi és intézményi struktúra megalakítása terén. 
Egyebek mellett a függetlenségről szóló népszavazásra is Szlovéniánál jóval később, 1991. május 24.-én került sor, ahol 83 \%-os részvétel mellett a választók 93,2 \%-a támogatta, hogy Horvátország független és szuverén állammá váljon (Juhász 1999, 226, Silber és Little 1996, 201-202).

Tudjmant a szlovéniai háború kitörése meglepetésként érte, noha Špegelj és az államfő környezetének más tagjai JNH-forrásokból már néhány nappal korábban értesültek a küszöbön álló beavatkozásról és ezt az információt Tudjman tudomására is hozták. Az elnök ugyanakkor nem csak ebben az időben, hanem még 1991 július végén is abban bízott, hogy a Horvátország elleni JNH támadásra nem kerül sor. Ezt a meggyőződését egy állítólagos, Milosevicstől és Kadijević védelmi minisztertől kapott ígéretre alapozta (Cigar 1997, 48, Silber és Little 1996, 205-206).

Épp ezért Tudjman ismételten elutasította Špegelj azon javaslatát, hogy a horvát fegyveres alakulatok vonják blokád alá a köztársaság területén lévő JNH laktanyákat, illetve, hogy szabotálják a JNH Szlovénia elleni horvátországi csapatmozgásait, noha Szlovénia és Horvátország nem sokkal korábban védelmi megállapodást kötött egymással. Az újabb politikai nézeteltérés miatt Špegelj 1991 július elején távozott a védelmi minisztérium éléről (Central Intelligence Agency 2002, 61, 111, Silber és Little 1996, 205-206, Spegelj 2001, 27, 34, Juhász 1999, 232).

\subsection{Háború és államépítés (1991-1995)}

\subsection{1. Általános politikai trendek}

A független horvát államiság első időszakát egyértelműen meghatározta az 1991 tavaszán szórványos összecsapásokkal kezdődő, majd a függetlenség kikiáltását követően fokozatosan háborúvá eszkalálódó horvátországi konfliktus. A háború következtében 1991 végére a horvát kormány az államterület közel egyharmada felett elveszítette az ellenőrzést, az 1992. januárjában ENSZ közvetítéssel megkötött fegyverszünet pedig ezt a helyzetet gyakorlatilag 1995 nyaráig „befagyasztotta” (Juhász 1999, 237-239, 245-246). A háborús helyzet ugyanakkor közvetlen politikai következményekkel is járt: az 1995-ig meglévő háborús fenyegetés állapota lehetővé tette az ostromállapot-mentalitás kialakulását a politikai kultúra és kommunikáció, illetve demokratikus játékszabályok korlátozását a gyakorlati politizálás terén (Cohen 1997, 84, Mihaljevic 2012, 127-130, Soberg 2007, 35-36). 
A háború ilyen értelemben „elterelő” (distraction), a politikai-gazdasági átalakulást megakasztó szerepet is játszott (Horowitz 2005, 161-162, Vankovska 2002, 58).

E helyütt ismételten szükségesnek tartom megemlíteni, hogy jelen fejezetben terjedelmi okok miatt nincs lehetőségem a horvátországi háború eseménytörténetét tárgyalni, így a kérdéses eseményekre csak jelzésszerüen és abban az esetben utalok, amennyiben azok a téma szempontjából relevánsak. ${ }^{15}$

Korábban említettem, hogy Szlovéniával ellentétben, Horvátország sokkal kevésbé volt felkészülve a függetlenség kikiáltása elött az önálló államiság intézményeinek létrehozását illetően. Részben ez is magyarázta, hogy egészen 1991 augusztusszeptemberéig a horvát elnök - esetenként saját kormányával és katonai vezetőivel is szembekerülve - védelmi-katonai téren is egyfajta „reaktív” stratégiát szorgalmazott. Ebben az időszakban Tudjman elsődleges opciója nem a szlovén típusú ellenállás, hanem részben a szerbekkel, illetve Belgráddal való megegyezés, illetőleg a nemzetközi közösség jóindulatának elnyerése volt (Central Intelligence Agency 2002, 91, Silber és Little 1996, 205-206, Cigar 1997, 48, Juhász 1999, 232, 237).

Ez a stratégia csak akkor változott meg, amikor 1991 kora őszén nyilvánvalóvá vált, hogy a háború (a szerbekkel, és Miloseviccsel való) megegyezés útján történő elkerülése csak akkor lett volna lehetséges, ha Horvátország lemond vagy a függetlenségről, vagy pedig a korábbi tagköztársasági határai sérthetetlenségéről mely politikailag természetesen elfogadhatatlanul magas árat jelentett volna Zágráb számára. (Juhász 1999, 237).

Miután Tudjmannal való nézeteltérései miatt Špegelj 1991 július elején lemondott, a következő 3 hónapban három különböző miniszter váltotta egymást a védelmi tárca élén, míg 1991 szeptemberében Tudjman bizalmi embere, Gojko Šušak foglalta el ezt a pozíciót (Ministarstvo obrane RH 2016, 298, Central Intelligence Agency 2003, 45 46, 91). A fent elmondottak miatt az 1991 augusztus-szeptemberéig tartó időszakban a horvát védelmi politika következetlen és „nem áttekinthető” (Mihaljevic 2012, 131), a védelmi tevékenység pedig „,szervezetlen” (Tus 2001, 46) volt.

Válaszul az egyre intenzívebb összecsapásokra, melyekben a JNH erői már aktívan az irreguláris szerb erők oldalán léptek fel, szeptember közepén került sor a Horvátország területén található JNH-laktanyák Špegelj által már korábban javasolt

\footnotetext{
${ }^{15}$ A horvátországi háborúról bővebben lásd pl. Juhász 1996, 21-29, Juhász 1999, 237-249, Zunec et al 2009, 231-270, Tus 2001, Silber és Little 1996, 228-254, Central Intelligence Agency 2002, 79-116, 265-280, 367-377, Ministarstvo obrane RH 2016, 10-83
} 
blokádjára, melynek köszönhetően a következő hetekben a horvát kormánykatonák jelentős mennyiségü fegyvert tudtak zsákmányolni (Juhász 1999, 239-240, Central Intelligence Agency 2003, 101-108).

A Horvát Hadsereg (Hrvatska Vojska, HV) 1991. szeptemberi megalakítása, a vezérkar létrehozása, illetve a már meglévő, és újonnan szervezett egységeknek a zsákmányolt fegyverekkel való felszerelése lényeges változást jelentett a nyári időszak „szervezetlen” védekezéséhez képest (Central Intelligence Agency 2003, 111-112, Tus 2001, 49-53, Vego 1993, 205-206, Mihaljevic 2012, 131-132).

A horvátországi háború első, 1991-92-es szakaszának fordulópontja 1991 októbernovemberére tehető. A szövetségi hadsereg offenzívája, melyet a JNH-laktanyák blokádjára válaszul 1991 október elején indított, részben Vukovár elhúzódó ostroma, részben pedig mozgósítási problémák miatt hamarosan elakadt. A horvátok ezáltal időt nyertek, amit a hadsereg újabb egységeinek felállítására és felfegyverzésére tudtak fordítani, ennek köszönhetően nem csupán a frontvonalat tudták tartani, hanem november végén és decemberben Nyugat-Szlavóniában sikeres ellentámadást is kezdeményezhettek. Erre az időszakra, Vukovár szerb kézre kerülését követően a Milosevics-féle szerbiai vezetés fő céljává a harctéri helyzet nemzetközi békefenntartók telepítésével való „,befagyasztása” vált (Cigar 1997, 35-37, Tanner 2001, 279-280, Juhász 1999, 239, 245, Vego 1993, 206, Central Intelligence Agency 2003, 175-177, 181-182, 207-208, Tus 2001, 61-63).

Különféle ellentétekre, nézetkülönbségekre a politikai és a katonai vezetök között 1991 őszén is több alkalommal sor került (Cigar 1997, 44). Ezzel kapcsolatban három jellemző példát érdemes kiemelni. A horvát elnök, Milosevics és Kadijević szövetségi védelmi miniszter 1991. november 23-án, Cyrus Vance ENSZbékeközvetítő jelenlétében egy megállapodást írták alá, mely a még blokád alá vont JNH-laktanyák ügyének megoldását célozta. A megállapodásban ugyanakkor volt egy, a tábornokok egy része - köztük a vezérkari fönök, Anton Tus - által ellenzett passzus is, mely lehetővé tette a JNH-nak a kérdéses laktanyákban tárolt teljes fegyverzetének kivonását. A vezérkari főnök Lord Carrington EK-közvetítőnek személyesen is kifejtette aggodalmát, hogy a kivont fegyvereket a JNH később vagy Horvátország, vagy pedig Boszniai-Hercegovina elleni támadásra használhatja fel (Cigar 1997, 54-56, Tus 2001, 63, Tanner 2001, 270-271).

A horvátországi konfliktus rendezésére irányuló Vance-terv tárgyalásai során az államelnök december 26-án váratlanul utasítást adott a nyugat-szlavóniai 
hadműveletek leállítására, mely Tus és Špegelj (aki 1992-ig „a hadsereg főfelügyelője" tisztséget töltötte be) éles tiltakozását váltotta ki, mivel álláspontjuk szerint néhány napon belül a megmaradt $\mathrm{kb} .500 \mathrm{~km}^{2}$-es területsávot is vissza lehetett volna foglalni (Cigar 1997, 44-45, Tus 2001, 61-63, Spegelj 2001, 37-38).

A vezérkari főnök ezen túlmenően ellenezte a Vance-terv horvát részről történő elfogadását is, azzal érvelve, hogy a katonai helyzet 1992 elején Horvátországnak kedvezett, valamint, hogy a terv tulajdonképpen csak a horvátországi szerb hódítások „befagyasztásához” vezetne (Cigar 1997, 44-45, Tus 2001, 63-65). Mint később kiderült, a tábornok ez utóbbi helyzetértékelése megfelelt a valóságnak (ld. pl. Juhász 1999, 245-247).

Mindhárom esetben azonban a politikai vezetők, közöttük leginkább Tudjman, akarata érvényesült. Ezek a politikai nézeteltérések 1992 során fokozódtak fel, konkrétan a Bosznia-Hercegovinával és az ott kirobbant konfliktussal kapcsolatban követendő katonai lépések kérdésében. Részben ezek a nézeteltérések vezettek Tus 1992 őszi távozásához is (Tus 2001, 65-66).

Gojko Šušak 1991 szeptemberi védelmi miniszteri kinevezését, de még inkább a közvetlen háborús helyzet 1992-es elhárulását követően erősödött fel a védelmi minisztérium átpolitizálódásának trendje, a HDZ-tagok, a HDZ-hez illetve vezetőihez közel állók, valamint a Šušak személyes pártfogoltjainak számító hercegovinai származású katonatisztek előtérbe kerülése révén (Vego 1993, 208-209, Lukic 2008, 194-195). A kilencvenes évek során általánossá vált, hogy a hadsereg tiszti és fötiszti karának tagjai, illetve a minisztert leszámítva döntően aktív állományú katonákból álló minisztériumi apparátus vezetői is a HDZ-hez tartoztak, sőt esetenként a katonai vezetők a párt egyes irányító testületeiben is részt vettek (Bellamy 2002, 176-177, Mihaljevic 2012, 136).

A hadsereg átpolitizálódása azonban nem merült ki a tisztek és fötisztek HDZtagságában. Az 1992. évi választásokon a kormánypárt jelöltjei között számos aktív állományú, magas rangú katona is megtalálható volt, a választási kampányban pedig a kormánypárt kommunikációja saját magát összekötötte a horvát hadsereg létrehozásával, és annak sikeres hadműveleteivel (Vankovska 2002, 58-59, Zunec 1996, 226, Mihaljevic 2012, 135-136). Általánosan jellemző volt, hogy a Tudjmanrezsim saját legitimitását a hadsereg magas társadalmi elfogadottságát „felhasználva” igyekezte erősíteni (Bellamy 2002, 175-176, 178, Bellamy 2003, 193-194).

Gojko Šušak miniszterségének kezdeti szakaszában alakult ki az a döntéshozatal 
rendkívüli centralizálására épülő irányítási és vezetési struktúra is, melynek következtében a védelmi-katonai terület minden lényeges kérdéséről egyszemélyben vagy az államfö, vagy bizalmi embere, Šušak döntött. Ezzel szemben a parlament gyakorlatilag elhanyagolható szerepet játszott, de több esetben a kormányt is „kihagyták” a döntéshozatalból. A kormány helyét esetenként ezen a szakterületen olyan elnöki tanácsadó testületek vették át, mint kezdetben a Legfelsőbb Államtanács, majd 1993 januárjától a Védelmi és Nemzetbiztonsági Tanács (VONS) (Bellamy 2002, 179-180, Dolenec 2013, 133-134, Vego 1993, 207-208, Edmunds 2007, 54-55).

A tisztikar lojalitását a politikai (párt-) kontroll fentebb leírt eszközei mellett anyagi előnyök, privilégiumok nyújtásával, így a katonai elit esetében például a kilencvenes években a „,bennfentesek” által dominált horvátországi privatizációban való részvétel lehetőségével, kívánták biztosítani (Edmunds 2007, 56-57). Részben ez is magyarázza, hogy a háború befejezését követően, a kilencvenes években is viszonylag magas maradt a katonai költségvetés (Bellamy 2002, 185-186, 188).

Ozren Žunec $(1996,226)$ és Marcus Tanner $(2001,291)$ szerint részben belpolitikai szempontok motiválták a HV két 1993. évi kisebb hadmüveletét is.

A stratégiai fontosságú - Dalmáciát az ország többi részével összekötő - maslenicai hídfő visszafoglalására irányuló 1993 januári támadást (bővebben lásd pl. Central Intelligence Agency 2002, 268) Žunec szerint úgy időzítették, hogy néhány héttel megelőzze a horvát felsőházi- és önkormányzati választást. Noha a hadművelet sikerrel járt, az eredményei inkább szimbolikus, vagy a hadsereg morálja szempontjából, mintsem katonai szempontokból voltak jelentősek (Zunec 2001, 70, Zunec 1996, 226, Tanner 2001, 288). A választás kimenetelét tekintve azonban a várt siker elmaradt: az 1993 februári választásokon a HDZ korábbi eredményeihez képest szavazatokat vesztett és több fontos önkormányzat az ellenzék „kezére” került (Cohen 1997, 93-95). Azt a tényt, hogy a müvelet során a horvát hadsereg relatíve jelentős veszteségeket szenvedett, csak egy év múlva hozták nyilvánosságra (Zunec 1996, 226).

A második, 1993. szeptemberi múvelet színhelye az ún. medaki kiszögellés (medački džep) volt, ahonnan a krajinai szerb erők rendszeresen lötték az egyik közeli horvát várost. A visszavételére irányuló hadművelet időzítésében pedig az játszhatott szerepet, hogy egy esetleges katonai sikerrel a Tudjman-kormányzat „leszerelje” a boszniai beavatkozás (lásd alább) miatti jelentős belső kritikákat (Tanner 2001, 291, 
a müvelet részleteit ld. pl. Central Intelligence Agency 2002, 269). A kérdéses területet a horvát erők ugyan elfoglalták, de őket utóbb az ENSZ békefenntartói váltották fel. Azonban mivel nyilvánosságra került, hogy a horvát offenzíva során a HV katonái a szerb civil lakosság elleni atrocitásokat is elkövettek, ez a hadművelet nemcsak katonailag, de politikailag és diplomáciailag is kudarccal ért fel Zágráb számára (Tanner 2001, 291, Pavlakovic 2008, 449-450).

Fentebb már tettem említést a Šušakhoz közel álló, hercegovinai származású tisztek a hadseregen és a minisztériumon belüli előtérbe kerüléséről. Az 1991-95-ös időszak legvitatottabb katonai döntését, a horvát hadsereg 1993-94-es, kis híján az ország nemzetközi elszigetelődéséhez vezető boszniai beavatkozását azonban hiba lenne pusztán Šušak és a „hercegovinai csoport” befolyására visszavezetni (Juhász 1999, 259, Hockenos 2003, 91-92). Maga Tudjman elnök sem tekintette életképes államalakulatnak Bosznia-Hercegovinát (lásd pl. Melcic 2008, 116-117, Zimmermann 1999, 181-183), és Zágráb a boszniai háború kitörését követően egyfajta „kettős politikát” folytatott ebben a kérdésben. Noha kezdetben a horvát kormány politikailag és katonailag is támogatta a boszniai horvátok és a bosnyákmuszlim központi kormány - szerbellenes - szövetségét, az államfő folyamatosan „lebegtette” az állam felosztásának lehetőségét is, annak érdekében, hogy a horvátlakta területek egy részét, Nyugat-Hercegovinát, Horvátországhoz csatolja. (Juhász 1999, 258-259, Ivankovic és Melcic, 2007, 423-424, Ramet 2010, 264-265). A boszniai horvát-muszlim konfliktus 1993 tavaszi kirobbanása után 1993 júliusától, a korábbi pénzügyi és logisztikai támogatás mellett a horvát reguláris hadsereg is a boszniai horvát fegyveresek, a HVO (Horvát Védelmi Tanács) oldalán avatkozott a harcokba (Silber és Little 1996, 399-401, Ivankovic és Melcic 2007, 427-429, Central Intelligence Agency 2002, 197).

A beavatkozást Horvátországban leginkább csak Tudjman és a hercegovinai származású politikai és katonai vezetők támogatták. A közvélemény túlnyomó többségének elutasítása és az ellenzéki pártok tiltakozása mellett ez a kérdés a HDZ-t is megosztotta, a Bosznia felosztására irányuló kormánypolitikát továbbá elítélte a Horvátországban nagy tekintélynek örvendő katolikus egyház vezetése is (Melcic 2008, 117-118, Ivankovic és Melcic 2007, 430-431, Juhász 1999, 258-259). Mivel a közvélemény jelentős része úgy érzékelte, hogy a horvát hadsereg agressziót követ el a szomszédos államban, noha alig két évvel korábban maga Horvátország is külső agresszió áldozata volt, a boszniai intervenció először rendítette meg a fegyveres 
erők addig töretlen társadalmi legitimitását, valamint erre az időszakra tehető a dezertálások számának jelentős növekedése is (Bellamy 2003, 188, 193-194, Vankovska és Wiberg 2003, 207-208, 215, Horowitz 2005, 157-158).

A horvát kormány csak 1994 tavaszán, jelentős nemzetközi nyomásgyakorlás hatására, és szankciók kilátásba helyezése után állt el ettől a politikától, és 1994 márciusában a washingtoni megállapodás révén beleegyezett a bosnyák-horvát föderáció megalakításába Bosznia-Hercegovinán belül. Az Egyesült Államok a föderáció horvát támogatásáért cserébe politikai támogatást ajánlott Zágrábnak a szerbek által megszállt területek Horvátországba való mielőbbi visszaintegrálása érdekében (Juhász 1999, 266-267, Tanner 2001, 291-292, Burg és Shoup 2015, $292-$ 294, Rudman 1996, 531-532, 539-541).

Az 1991-esnél sokkal jobban kiképzett, felfegyverzett és felszerelt horvát hadsereg 1995. májusában és augusztusában a „Vihar” és „Villám” hadműveletek révén felszámolta a Krajinai Szerb Köztársaságot. E müveletek sikere azonban köszönhető volt annak is, hogy Belgrád ekkorra már gyakorlatilag „leírta” a szakadár krajinai szerb államalakulatot és nem kívánt katonailag beavatkozni horvátországi „kliense” érdekében. (Central Intelligence Agency 2002, 362-363, Juhász 1999, 248-249, $267-$ 270). Ezen túlmenően 1995-re az amerikai politika is megváltozott, Washington immáron a milosevicsi Szerbia egyfajta „ellensúlyának” tekintette Horvátországot, melynek katonai fellépése a boszniai válság megoldásához is hozzájárulhat. Emiatt az amerikai kormány legalábbis jóindulatú semlegességgel viszonyult az 1995. nyári horvát hadmüveletekhez (Cohen 1997, 105-106, Burg és Shoup 2015, 326-327, 337338, Juhász 1999, 272-274).

A „Vihar” hadmüvelet következtében az érintett területen élő szerb lakosság nagy része elmenekült, a művelet befejezését követő hetekben pedig több helyen súlyos atrocitásokra került sor a hátramaradt kis számú szerb lakos ellen (Cohen 1997, 103 105, Vankovska és Wiberg 2003, 208-209). A hágai Jugoszlávia-törvényszék (ICTY) a Vihar-hadmüvelet miatt később több, a hadműveletben érintett katonai és rendőri vezető ellen vádat emelt (Pavlakovic 2008, 449-450).

\subsubsection{Jogi-intézményi és szervezeti változások}

Noha a függetlenség kikiáltását követően történtek lépések a fegyveres erők jogiintézményi kereteinek kialakítására, mint például június 26-án a honvédelmi törvény 
elfogadásával, illetve, július 30-án a ZNG országos parancsnokságának megalakításával, egészen 1991 kora őszéig a védelmi erőfeszítések szervezetlenek maradtak (Tus 2001, 46-48, Vankovska és Wiberg 2003, 206-207). Gyenge koordináció mellett működtek egymással párhuzamosan a belügyminisztérium és a ZNG egységei, az ekkor felállított járási és helyi válságstábok - melyek a gyakorlatban általában felfegyverzett HDZ-aktivisták csoportjait jelentették -, valamint az állami struktúrákon teljesen kívül eső paramilitáris csoportok is, melyek közül a HSP Horvát Védelmi Erők (HOS) nevü milíciája volt a legjelentősebb (Central Intelligence Agency 2002, 85-86, Vego 1993, 205-206).

Ez a helyzet 1991 szeptemberétől változott meg, amikor formálisan megalakították a Horvát Hadsereget (Hrvatska Vojska, HV), felhívást intéztek a JNH horvát nemzetiségü katonáihoz és tisztjeihez, hogy csatlakozzanak az új haderőhöz, valamint megszervezték a HV vezérkarát is. A HV első vezérkari fönöke Anton Tus, a JNH légierejének korábbi, pozíciójából 1991 májusában eltávolított parancsnoka lett. Intézkedtek továbbá a válságstábok felszámolásáról, vagy a vezérkar alá rendeléséről, illetve a különböző milíciák (elsősorban a HOS) a kormányhadseregbe való integrálásáról is (Vego 1993, 205-206, Tus 2001, 49-51, Central Intelligence Agency 2003, 111-112, Mihaljevic 2012, 131-132).

A HV alapjait tehát - a JNH-laktanyák blokádja során zsákmányolt fegyverek felhasználásával - 1991-92-ben Tus fektette le, viszont későbbi struktúrájának kialakítása és további kiképzése már utódja, Janko Bobetko (1992-95) irányításával történt (Vego 1993, 206-207, Central Intelligence Agency 2002, 267).

Alapvetően négy jelentősebb csoport képviselői voltak megtalálhatóak a kilencvenes évek elején a HV soraiban: a JNH-ból 1991 folyamán a horvát hadsereghez csatlakozók, a diaszpórából érkezők, akik sok esetben korábban a francia idegenlégióban vagy más államok hadseregeiben szolgáltak, a horvát területvédelem tisztjei és katonái, valamint a védelemben részt vevő önkéntesek és HDZ-aktivisták, akiknek általában semmiféle katonai képzettségük nem volt (Zunec 1996, 220-221, Lukic 2008, 193-196). Ez utóbbi csoport tagjai sok esetben képzettségük hiánya ellenére megfelelő politikai kapcsolatok birtokában rövid idő alatt magas beosztásba kerülhettek (Vankovska 2002, 66-67, Lukic 2008, 196). Például az eszéki vezető HDZ-politikus, Branimir Glavas 1991-ben csatlakozott a HV-hez, két évvel később a köztársasági elnök javaslatára már dandártábornokká léptették elő (Lukic 2008, 196, Zunec 1996, 225). A hatalom általában a katonai szaktudással szemben vagy a 
politikai megbízhatóságot és a személyes kapcsolatok meglétét vagy pedig a harctéri teljesítményt és tapasztalatot részesítette előnyben, ezért a korábbi JNH-tisztek általában csak akkor futottak be komolyabb karriert a kilencvenes évekbeli HV-ben, ha közel álltak a HDZ-hez vagy legfelsőbb vezetőihez (Edmunds 2007, 124-125, Lukic 2008, 194-196). A politikailag megbízhatatlannak tartott JNH-múltú tisztek és tábornokok háttérbe szorítása ugyanakkor gátolta a katonai professzionalizmus kialakítását, különösen, mivel a helyükbe lévő utódaiknak sokszor nem volt megfelelő katonai képzettségük (Vego 1993, 208-209, Zunec 1996, 221).

Az aktív állományú katonák politikai tevékenysége kezdetben jogellenesnek számított, mivel az 1991. évi honvédelmi törvény erre vonatkozó tilalmat tartalmazott (Vankovska 2002, 59). Ezen tilalmat azonban már akkor sem tartották be, az 1992-ben kibocsátott szolgálati szabályzatban már nem szerepelt a politikai tevékenységre vonatkozó kitétel, majd a tilalmat 1993-ban a honvédelmi törvényből is törölték (Mihaljevic 2012, 135-136). Ugyanezen időpontban a védelmi minisztériumon belül a Politikai Főosztályt is létrehozták. A katonai sajtó ezen időszakban gyakran használta HV-n és a minisztériumon belül tevékenykedő, politikai kérdésekkel is foglalkozó tisztekre a „politikai dolgozók” (politicki djelatniki) kifejezést, mely bizonyos mértékben hasonlatos volt a JNH-ban bevett, politikai ügyekért felelős parancsnokhelyettes intézményéhez (Zunec 1996, 225-226, Domjancic 2015, 171-172).

A főtisztek és tábornokok képviselőjelöltségéről fentebb már említést tettem. Általában ilyenkor megválasztása esetén az érintett lemondott mandátumáról egy politikus javára, néhányan viszont, mint például Ivan Tolj, a minisztérium politikai főosztályának vezetője, vagy a már említett Branimir Glavas, ténylegesen el is foglalták a parlament alsó- vagy felsőházában megszerzett képviselői helyüket. A hadsereg tagjainak ilyen és hasonló pártpolitikai szerepvállalására vonatkozó ellenzéki kritikákat a HDZ politikusai ekkoriban azzal utasították el, hogy a politikai tevékenység tiltása „sértené a katonák emberi jogait” (Zunec 1996, 225-227, Mihaljevic 2012, 135-137, Vankovska és Wiberg 2003, 210-211).

A korábban már említett, az államfő egyszemélyi vezetésére épülő vezetési struktúra sajátos elemét képezték a hadsereg parancsnoki láncán kívül álló, közvetlenül az államfő vagy a miniszter irányítása alatt álló katonai egységek, melyek létét kezdetben igyekeztek titokban tartani. Az ilyen egységek legjellemzőbb példája az 1. gárdaezred (közkeletü nevén „elnöki gárda”) volt, de Reneo Lukić (2008, 198) 
szerint egyes különleges müveleti egységek is tartoztak ebbe a kategóriába, melyeket a bosnyák-muszlim konfliktus során is bevetettek (Zunec 1996, 220, Vankovska 2002, 68-69, Domjancic 2015, 174). Több esetben volt példa párhuzamos, vagy informális parancsnoki struktúrákra is, melyek általában a HDZ belső szervezetére épültek (Lukic 2008, 198, Zunec 2001, 68-70, Spegelj 2001, 34-35).

A védelmi tárca és a hadsereg pénzügyeit ebben az időszakban egyértelmüen a titkosság és az átláthatóság teljes hiánya jellemezte. Az erre vonatkozó adatokat általában a parlament tudomására sem hozták, 1998-ig a védelmi minisztérium gazdálkodását az állami számvevőszék sem auditálta. A Šušak halála után rövid ideig a védelmi miniszteri tisztséget betöltő Andrija Hebrang egy korabeli nyilatkozata szerint 1995-ig a tárcánál modern értelemben vett könyvvitelröl nem lehetett beszélni, valamint a hivatalos költségvetésen kívül több titkos vagy „fekete” pénzalap is létezett, mely felett csak az akkori miniszter bírt rendelkezéssel. Az átláthatóság hiánya és a védelmi tárca tisztázatlan belső viszonyai a korrupcióra és a pazarló gazdálkodásra is széles körü lehetőséget teremtettek (Cehulic és Vukadinovic 2001, 71, Mihaljevic 2012, 138, Zunec 1996, 227).

Hasonlóképpen, nem léteztek a katonai-védelmi politika általános irányvonalait tartalmazó nyilvános stratégiai dokumentumok sem, a parlament fegyveres erőkért felelős belügyi és nemzetbiztonsági bizottsága pedig a gyakorlatban nem, vagy csak jelentéktelen szerepet játszott a hadsereg feletti ellenőrzésben (Lukic 2008, 197-198, Zunec 1996, 220-221, 226-227).

\subsubsection{A védelmi szféra nemzetközi dimenziója}

A kilencvenes években a nemzetközi közösségnek a jugoszláviai válság rendezésére irányuló erőfeszítései részben a horvátországi konfliktus megoldását is céloztak.

E helyütt nem kívánom bővebben tárgyalni sem a Horvátország nemzetközi elismerése körüli nemzetközi vitákat, illetve az országot is érintő nemzetközi béketerveket, mint például a Carrington-terv és a Vance-terv (bővebben lásd pl. Juhász 1999, 242-245, Meier 1999, 207-234, Silber és Little 1996, 255-274), sem pedig a horvátországi ENSZ békefenntartó erő (UNPROFOR) tevékenységét (erről lásd pl. Ekwall-Uebelhart 1996, 23-54, 105-120).

Röviden érdemesnek tartok megvizsgálni azonban két, a nemzetközi szereplőkhöz köthető kérdést, mely megítélésem szerint hatást gyakorolt a horvát civil-katonai 
kapcsolatokra ebben az időszakban: az ENSZ-fegyverembargó kérdését, valamint a Military Professional Resources Inc. (MPRI) amerikai katonai magáncég horvátországi tevékenységét.

A volt Jugoszlávia utódállamaira vonatkozó fegyverembargót az ENSZ Biztonsági Tanácsa 1991 szeptemberében fogadta el (Hockenos 2003, 86). Az embargó 1992 és 1995 között érdemben nem gátolta Horvátország fegyvervásárlásait, mivel megkerülése viszonylag egyszerü volt és ezt elősegítették az ország földrajzi adottságai is. A boszniai horvát-muszlim föderáció 1994. márciusi megalakításától kezdve az Egyesült Államok még inkább szemet hunyt az embargó horvát megsértése felett (Burg és Shoup 2015, 338-339, Edmunds 2007, 125, Hockenos 2003, 97-99). Az embargó hatása az általam vizsgált területen azáltal jelentkezett, hogy a horvát fegyverbeszerzések 1991-1995 között szükségszerüen konspiratív és rejtett, félig vagy teljesen illegális csatornákon keresztül történtek. A sokszor átláthatatlan, titkos pénzalapok felhasználásával, vagy bünözői hálózatok bevonásával történő tranzakciók során jelentős volt a korrupció és a pénzügyi visszaélés is. Mindezen tendenciák tovább fokozták a védelmi szférában a háborús helyzet, valamint az elnöki hatalom-koncentráció miatt amúgy is meglévő demokratikus deficitet (Dolenec 2013, 139-140, Edmunds 2007, 124-125, Hockenos 2003, 84-89).

Az MPRI amerikai katonai tanácsadó céggel a horvát kormány először 1994 szeptemberében kötött szerződést, hivatalosan azzal a céllal, hogy a cég nyújtson szervezetfejlesztési és képzési támogatást a HV és tisztikara számára a hadsereg demokratikus társadalomban játszott szerepe területén (Vankovska 2002, 69, 71). Tekintettel ugyanakkor, hogy a szerződés megkötésére az MPRI részéről eleve az amerikai külügyminisztérium engedélyével került sor, többen (Hockenos 2003, 9697, Vankovska 2002, 62-63, Edmunds 2007, 208) azon az állásponton vannak, hogy a cég megbízása a korábban említett, Washington és Zágráb közötti „kompromisszum” eredménye. A muszlim-horvát föderáció horvát támogatásáért cserébe a területi integritása helyreállításához nyújtott amerikai segítségnyújtás csatornája az MPRI lett (Hockenos 2003, 99-100, Vankovska 2002, 70-71). A szerződésben szereplő képzések a háború befejezéséig a HV személyzetének csak egy kis részét érintették, ugyanakkor a MPRI szerződését 1995-1996-ban meghosszabbították, és más tevékenységekre is kiterjesztették (Vankovska 2002, 71, 73, Lukic 2008, 199-200). 
Noha az MPRI hivatalosan tagadta, hogy munkatársai taktikai és stratégiai felkészítést is nyújtottak a Horvát Hadsereg számára, a jelek arra mutatnak, hogy a szervezet közvetett vagy közvetlen módon a HV 1995. évi hadműveleteinek előkészítésében illetőleg végrehajtásában is szerepet játszott (Hockenos 2003, 99100, Vankovska 2002, 72-73, Burg és Shoup 2015, 339-340, Edmunds 2007, $192-$ 193, Lukic 2008, 199-200). A „Vihar” és „Villám” hadmüveletek sikerében játszott valószínűsíthető - szerepe mellett a MPRI a hadseregek közötti kapcsolatok (military-to-military contacts) limitált és közvetett csatornájaként is funkcionált egy olyan időszakban, amikor a védelmi együttmüködés multilaterális formáiban (például a NATO Békepartnerségi programja) való részvétel Horvátország számára nem volt lehetséges (Edmunds 2007, 192). Biljana Vankovska ugyanakkor arra mutat rá, hogy az MPRI megbízására vonatkozó döntést, a parlament és a kormány nagyobb részének kizárásával közvetlenül Tudjman és Šušak hozta meg. Noha a cég katonai tanácsadóinak Zágrábba érkezését a HDZ-kormányzat jelentős politikai sikerként könyvelte el, és ekként is propagálta, a szervezet későbbi horvátországi müködését általánosságban titkosság övezte. Mindez pedig ellentétben áll az MPRI megbízásának hivatalos céljával, a haderő demokratikus társadalomban játszott szerepére vonatkozó tanácsadással (Vankovska 2002, 78).

\subsubsection{A magyarázó tényezők hatásának értékelése}

A jugoszláv időszak történelmi örökségét, illetve ennek a civil-katonai kapcsolatokra gyakorolt hatását illetően sajátos ellentmondás volt megfigyelhető a Tudjman-rezsim időszakában. A HDZ államépítő projektje alapvetően Jugoszláviával szemben határozta meg magát (lásd pl. Vankovska és Wiberg 2003, 201-202), valamint az államfö is előszeretettel vádolta azzal a politikáját bírálókat, hogy Jugoszláviát szeretnék visszaállítani (Cohen 1997, 111, Ramet 2010, 273). A hadsereg feletti politikai kontrollban mégis bizonyos mértékig a titói Jugoszláviára jellemző megoldások és politikai technikák voltak megfigyelhetőek.

Stjepan Domjančić (2015, 171-172) sajátos horvát paradoxonként említi, hogy a HV egyfelöl a JNH, vagy a JNH által támogatott, kiképzett, és felszerelt erők ellen harcolt, sikerei mégis részben JNH-doktrínákra alapultak, illetőleg a kormányzathoz, politikához és a társadalomhoz való viszonyában is sok esetben a JNH jelentette a mintát. Reneo Lukić (2008, 190-191) szintén arra mutat rá, hogy a civil-katonai 
kapcsolatok a tudjmani Horvátországban bizonyos mértékig párhuzamba állíthatóak a titói Jugoszláviát jellemzőkkel.

Az 1991 és 1995 zajló fegyveres konfliktus hatása több területen, illetőleg több csatornán keresztül jelentkezett. Általánosságban, mint korábban már említettem, a háború a gazdasági-politikai átalakítást megakasztó, vagy lelassító szerepet játszott, illetve a nemzetbiztonsági szempontokra való hivatkozás időről-időre indoklásul szolgált a demokratikus játékszabályok megkerüléséhez (Horowitz 2005, 161-162, Vankovska 2002, 58-59, Vankovska és Wiberg 2003, 209-210). A konfliktus ugyanakkor közvetlenül is hatást gyakorolt a hadsereg szervezetére: befolyásolta a horvát fegyveres erő létrejöttének módját, létszámát, belső összetételét, illetve az előléptetés módjait és lehetőségeit is (Edmunds 2007, 121-124, Bellamy 2002b, 176177). Dolenec $(2013,138)$ szerint a háború elősegítette a politikai folyamatok kriminalizálódását és a korrupció elterjedését is. A kriminalizációs tendenciák egy közvetett csatornája volt a hercegovinai horvátok Zágráb általi finanszírozása, mivel a szakadár Herceg-Boszna államalakulaton belül a politikai-katonai és a bünözői struktúrák egymástól nehezen voltak elválaszthatóak (Hockenos 2003, 93-96).

Több esetben a háború és a hadsereg politikai instrumentalizációja, eszközként való felhasználása valósult meg a regnáló politikai elit, és az államfó által: a politikai vezetés igyekezett a hadsereg magas társadalmi elfogadottságát és a háborúban elért katonai sikereket felhasználni saját pozíciója és nacionalista politikai programja alátámasztására (Vankovska 2002, 77, Vankovska és Wiberg 2003, 209-210).

A háborús helyzet mellett a legmeghatározóbb hatást a civil-katonai kapcsolatokra ebben az időszakban a belső politikai környezet jellege gyakorolta. Mint korábban említettem, a horvát hadsereg részben egyszemélyi (az államfö), részben pártkontroll alatt állt, eme kontroll három csatornája pedig a döntéshozatal centralizálása, a kormányzó párt jelenléte a hadseregben, illetve a tisztikarnak nyújtott anyagi elönyök és privilégiumok voltak (Edmunds 2003, 14-15).

A szakirodalom véleménye eltér abban a tekintetben, hogy elméletileg hogyan értelmezhetőek a civil-katonai kapcsolatok a tudjmani Horvátországban. Stjepan Domjančić $(2015,173)$ és Ozren Žunec $(1996,219$, 224) szerint az Eric J. Nordlinger (1977) nevéhez köthető penetrációs modell némi megszorítással alkalmazható Horvátországra, mivel az államfó és a legfelső politikai vezetés a hadsereg feletti politikai kontrollt, a domináns pártnak a katonai ranglétra különböző szintjein történő jelenlétével (a hadsereg szervezetébe történő „penetrációval”) biztosították. 
Vankovska és Wiberg ugyanakkor vitatják a penetrációs modell Horvátországra való érvényességét, arra hivatkozva, hogy a HDZ ebben az időszakban nem vált „klasszikus” politikai párttá és nem rendelkezett kialakított ideológiával sem az etnonacionalizmuson túlmenően (Vankovska és Wiberg 2003, 217, Vankovska 2002, 59). Edmunds $(2007,57)$ és Bellamy $(2002$, 175-176) szerint a Tudjman-éra alatt a horvát hadsereg pártkontrollja részben formális, részben informális csatornákon keresztül valósult meg, és ezen kontrollban jelentős szerepet játszott a klientelista hatalomgyakorlási módszerek és struktúrák. Az informális pártkontroll-csatornákat később esetenként intézményesítették, vagy törvényben is kifejezést nyertek (Mihaljevic 2012, 137, Domjancic 2015, 174).

A haderő feletti civil kontroll ugyanakkor ebben az időszakban soha nem kérdőjeleződött meg, de fontos megjegyezni, hogy ez esetben autoriter, és nem demokratikus civil kontrollról beszélhetünk (Horowitz 2005, 162-163, Edmunds 2007, 54, Bellamy 2002, 177). A hadsereg a politikai elit és a Tudjman-rezsim kliense volt, nem vált autonóm politikai szereplővé, így a háborús helyzet ellenére nem volt jellemzö, hogy a katonák külpolitikai vagy biztonság- és védelempolitikai kérdésekben befolyással rendelkeztek volna (Zunec 1996, 226-227).

A nemzetközi tényezők hatása, noha kétségtelenül kimutatható, a horvát független államiság kezdeti időszakában korlátozott volt. Az ENSZ által bevezetett fegyverembargó a horvát hadsereg fegyverbeszerzéseinek konspiratív jellegéhez járult hozzá, tovább növelve az átláthatóság hiányát és a demokratikus deficitet a fegyveres erők politikai kontrolljában (Edmunds 2007, 124-125, Dolenec 2013, 139140). A bilaterális védelmi együttmüködés ebben az időszakban csak igen korlátozottan és közvetett módon, az MPRI részvételével volt jelen, a cég tevékenységének a civil-katonai kapcsolatokra gyakorolt hatása korlátozott volt.

Mindenképpen megemlítendő még az egyes nemzetközi szereplők, közöttük az Egyesült Államok, általi nyomásgyakorlás szerepe, mely több esetben (leginkább a boszniai konfliktusba történő horvát beavatkozás idején) vezetett a horvát katonaibiztonsági döntések felülvizsgálatához (ld. Tanner 2001, 291-292). Ezen túlmenően, az említett döntéseket befolyásolta az átalakuló amerikai politika is, mely 1994 elejétől Horvátországot a Milosevicsi Szerbia egyfajta „hasznos ellensúlyának” tekintette. Az amerikai politika említett irányváltása vezetett az MPRI-vel való horvát kapcsolatfelvételhez is (Cohen 1997, 105-106, Edmunds 2007, 125, Burg és Shoup 2015, 339, Hockenos 2003, 97-99). 


\subsection{Fegyveres erők és autoriter hatalomgyakorlás (1995-1999)}

\subsubsection{Altalános politikai trendek}

A Tudjman-éra utolsó, 1995 és 1999 közötti időszakának fő jellemzője a háborús időszakra jellemző politikai és hatalmi technikák folytatódó alkalmazása annak ellenére, hogy a háborús helyzet már megszünt (Dolenec 2013, 142-143, Soberg 2007, 33-34, 46-47). Továbbra is jelen voltak az olyan autoriter vagy illiberális politikai tendenciák és intézkedések, mint a demokratikus játékszabályok „szelektív értelmezése" (Cular 2000, 39), az elektronikus média szinte teljes kormányzati kontrollja, a kormánykritikus sajtóorgánumokra, civil szervezetekre és politikai aktivistákra történő nyomásgyakorlás, noha korábban több esetben ezeket a háborús helyzettel indokolták (Soberg 2007, 33-35, Dolenec 2013, 142-143, Cular 2000, 3540). Dolenec $(2013,133,143)$ szerint az 1995 nyári háborús győzelem egyfajta „legitimitási tartalékot” képezett a HDZ és a Tudjman-rezsim számára, mely egy ideig még lehetővé tette a korábbi autoriter jellegü politikai kurzus továbbvitelét.

A háború után is tovább folytatódó autoriter politizálásra az ún. zágrábi válság jelentette az első és legjellemzőbb példát. Azzal a céllal, hogy politikailag „hasznot húzzon" a krajinai szerbek felett aratott 1995. nyári katonai győzelemből, az államfő előrehozott választásokat írt ki 1995 októberére. A kormánypárt jelentős médiafölénye és a választási rendszer neki kedvező módosítása ellenére a HDZ a parlamenti választáson érdemben nem tudta növelni szavazatai számát 1992-höz képest, a Zágrábban tartott időközi önkormányzati választáson pedig az ellenzék jelöltjei szereztek többséget. Az államfő egy alkotmányos jogköre (az ún. kinevezési vétó) felhasználásával több alkalommal is megakadályozta a városi képviselő-testület által megválasztott polgármester hivatalba lépését, így a horvát fóvárost 17 hónapon keresztül, az 1997-es helyhatósági választásokig egy kormánybiztos irányította (Cohen 1997, 106-11, Dolenec 2013, 142-143, Bellamy 2003, 189-190).

A belső viszonyokban megfigyelhető demokratikus deficit mellett a Tudjmankormányzat egyes külpolitikai lépései is jelentős nemzetközi bírálatokat váltottak ki: Horvátország csak igen korlátozottan működött együtt a volt Jugoszlávia területén elkövetett bűnöket vizsgáló hágai törvényszékkel (ICTY), valamint Zágráb ekkori Bosznia-politikája is alapvetően a daytoni rendezés aláásására irányult. A horvát kormányzat ugyanis továbbra is finanszírozta a daytoni egyezménybe ütköző 
„Herceg-Boszna” különböző politikai és katonai struktúráit. Ezen intézkedések, különösen 1998-tól, az ország növekvő nemzetközi elszigetelődéséhez vezettek (Economist Intelligence Unit 1998b, 13-14, Tanner 2001, 303-304).

A civil-katonai kapcsolatok alapvető mintái hasonlóak voltak az előző periódusban tapasztalhatókhoz: néhány kozmetikai jellegủ változástól eltekintve nem került sor a demokratikus kontroll intézményi-politikai struktúráinak kialakítására, sem pedig a hadsereg nem vált autonóm szereplővé. A fegyveres erőknek a rezsim továbbra is legitimációs szerepet szánt, kommunikációjában pedig fontos szerepet kapott az 1995-ben véget ért „Honvédő Háború” (domovinski rat) egyfajta „mitologizációja” is. Ebben az időszakban a háború és az abban aratott győzelem még inkább az állam és a HDZ-rezsim alapvető „,eredetmítoszává”, legitimációjának alapvető elemévé vált (Bellamy 2002, 181, Bellamy 2003, 190, Bellamy és Edmunds 2005, 72-73).

A Horvát Hadsereg (1996-tól Horvát Fegyveres Erők, OSRH) belső viszonyait a „befelé forduló stagnálás” (Edmunds 2007, 127) jellemezte: szerkezete és föbb feladatai alapvetően 2000-ig keveset változtak 1995-höz képest. Nem történt változás azon a téren sem, hogy a védelmi minisztérium inkább volt ,állam az államban” mint a központi közigazgatás egyik alkotóeleme: gazdálkodása és müködése továbbra is átláthatatlan volt, illetve a védelmi tárca képezte a fó csatornát a boszniai horvátok már említett finanszírozásában is (International Crisis Group 1998, 7-8, Economist Intelligence Unit 1998, 11-12, Mihaljevic 2012, 139-140).

A Tudjman egyik legközelebbi munkatársának számító Gojko Šušak 1998 májusi halála egybeesett a HDZ-n belüli „mérsékelt” és „keményvonalas” szárny közötti frakcióküzdelmek elmélyülésével is (International Crisis Group 1998, 4-5).

Šušak halála után az államfő Andrija Hebrangot nevezte ki a védelmi tárca élére, aki nem a párt mérsékelt szárnyához tartozott, de korábban egészségügyi miniszterként a takarékos pénzügyi gazdálkodás elvét képviselte. Hebrang tervei között szerepelt a minisztérium müködtetésének racionalizálása és átláthatóbbá tétele, a hozzá tartozó állami vállalatok gazdálkodásának felülvizsgálata, továbbá a demokratikus kontroll erösítése a tárca müködésében. Mivel az általa tervezett reformokat a párt keményvonalasai ellenezték a legjobban, Hebrang a kibontakozó párton belüli vitában voltaképpen a mérsékelt szárnnyal került egy platformra (Cehulic és Vukadinovic 2001, 83-84, International Crisis Group 1998, 7-8, Mihaljevic 2012, 138-140). A tárca reformjára vonatkozó intézkedések leginkább három minisztérium vezető ellenállásába ütköztek: Ljubo Ćesić Rojs a pénzügyi kérdésekért, Vladimir 
Zagorec a katonai beszerzésekért, Markica Rebić pedig a katonai hírszerző szolgálatokért felelős miniszterhelyettes volt (mindhárman tábornoki rangban).

Ćesić Rojs a boszniai horvátok finanszírozásában játszott kulcsszerepet, Zagorec pedig miniszterhelyettesi tisztsége mellett a fegyverek és hadianyagok exportimportjával foglalkozó RH Alan állami vállalat elnöki pozícióját is betöltötte (Economist Intelligence Unit 1998, 14-15). Az intézkedéseit ellenző három miniszterhelyettest Hebrang nem tudta eltávolítani, mivel a tárcavezető, és helyettesei közötti vitában Tudjman több alkalommal is utóbbiak mellett foglalt állást. A hercegovinai csoport befolyásos tagjai mellett Šušak özvegye is közben járt Tudjmannál, hogy az államfő akadályozza meg Ćesić Rojs, Rebić és Zagorec a minisztérium vezetéséből való eltávolítását. Az államfő magatartását az is motiválta, hogy politikailag őt magát is igen kellemetlenül érintette volna, ha bebizonyosodik, hogy a minisztérium egyes kétes tevékenységei az ő tudtával vagy hallgatólagos beleegyezésével zajlottak (International Crisis Group 1998, 9, Economist Intelligence Unit 1998, 15).

Hebrang politikai pozícióját a párt keményvonalasaival szemben rontotta, hogy jó amerikai kapcsolatokkal rendelkezett: az 1998 augusztusában Horvátországba látogató Madeleine Albright amerikai külügyminiszter élesen bírálta Zágráb Boszniával kapcsolatos politikáját, ugyanakkor elismeréssel nyilatkozott a miniszter reformjavaslatairól a védelmi tárcánál. Arra hivatkozva, hogy a továbbiakban láthatóan már nem élvezi az államfő bizalmát, Hebrang 1998 októberében lemondott (Economist Intelligence Unit 1998b, 12).

Hebrang lemondása után az Tudjman azt a Pavao Miljavacot nevezte ki a minisztérium élére, aki hivatalba lépése (és nyugállományba helyezése) előtt egy nappal még a vezérkari főnök tisztségét töltötte be. Korlátozott átalakításokra ugyan sor került Miljavac vezetése alatt is, de a minisztérium tényleges reformja már csak a 2000. évi „rezsimváltás” után kezdődött meg (Mihaljevic 2012, 138).

Az akkori, erre vonatkozó sajtóbeli találgatásokkal (ld. pl. Bellamy 2001, 22, 26) ellentétben semmiféle politikai beavatkozásra nem került sor a hadsereg részéröl a HDZ-rezsim bukásának megakadályozására, mely több tényezővel is magyarázható. Az elsődleges és alapvető ok, hogy mint korábban említettem, a horvát hadsereg a Tudjman-érában nem volt autonóm politikai szereplő, hanem a kormányzó párt egyfajta klienseként funkcionált (Zunec 1996, 226-227). 
A hadsereg vezetése egyértelmüen tudtában volt annak is, hogy belső és nemzetközi viszonyok ismeretében egy ilyen beavatkozás nem vezethet sikerre

Ezen túlmenően a HDZ támogatottságának eróziójával párhuzamosan a hadsereg korábbi igen magas társadalmi elfogadottsága is megrendült, mivel a választók egy része a fegyveres erőket különböző visszaélésekkel és korrupciós ügyekkel azonosította (Vankovska 2002, 82, Edmunds 2007, 57-58, Bellamy 2003, 194).

Hogy e vélemények mennyire széles körben jelen voltak a társadalomban az is bizonyítja, hogy Franjo Kuharic bíboros, a horvát katolikus egyház vezetője egy 1999 szeptemberi, a „Zrínyi Péter” (Petar Zrinski) katonai akadémián tett látogatásakor arról beszélt, hogy a hadsereget „meg kell tisztítani” az erkölcstelenségtől, az önzéstől, a korrupciótól és a magánérdek szolgálatától (Mihaljevic 2012, 141).

\subsubsection{Jogi-intézményi és szervezeti változások}

A korai szervezeti változások egy része közvetlenül a háborús helyzet megszűnésével függtek össze, mint például a demobilizáció, vagy a hadsereg területi struktúrájának átalakítása, vagy alapvetően szimbolikusak voltak, mint a Horvát Hadsereg elnevezés Horvát Fegyveres Erőkre (Oružane Snage Republike Hrvatske, OSRH) változtatása 1996-ban (Ministarstvo obrane RH 2016, 87, Cehulic és Vukadinovic 2001, 74).

Politikai szempontból nagyobb volt a jelentősége azon 1995-ös törvénymódosításnak, mely megtiltotta az aktív állományú katonák számára képviselői mandátum betöltését. A jogszabály azonban magát a képviselőjelöltséget továbbra sem tiltotta, így a HDZ például az 1997-es felsőházi választáson is szerepeltetetett jelöltjei között magas rangú tábornokokat, közöttük az akkori vezérkari főnököt, Pavao Miljavacot (AIM Press 1997, Vankovska és Wiberg 2003, 211, Mihaljevic 2012, 137-138). Így tehát a kormánypárt továbbra is felhasználhatta a hadsereg vagy vezetői társadalmi presztízsét politikai haszonszerzésre (Domjancic 2015, 174). Ugyanebben az időszakban megszüntették a „politikai dolgozók” tevékenységét a fegyveres erőkben, és Közkapcsolati Főosztályra „keresztelték át” a Politikai Főosztályt is. Mint Domjančić megjegyzi, ezek azonban alapvetően formális, „kozmetikai” változtatások voltak, és nem jelentették azt, hogy a kormánypárt jelenléte is megszünt volna a hadseregen belül (Domjancic 2015, 172). Fentebb már említettem, hogy Gojko Šušak 1998 májusi haláláig érdemben nem 
változott a védelmi tárca ,állam az államban” mivolta sem: irányítását a hatalom koncentrációja, gazdálkodását továbbra is az átláthatatlanság és titkosság jellemezte, emellett továbbra is a minisztérium maradt a boszniai horvátok, és informálispárhuzamos állami struktúráik fő finanszírozási csatornája. Mindezek miatt annak ellenére, hogy a háború véget ért, a „békeosztalék” (peace dividend) csak korlátozottan érvényesült és továbbra is magas maradt a védelmi kiadások szintje (Bellamy 2002, 185-186, 188, Bellamy 2003, 188-189, Mihaljevic 2012, 138-140).

A védelmi rendszer békeidőbeli struktúráját volt hivatott kialakítani az a két 1997 decemberben kiadott elnöki rendeletet, melyek a minisztérium és a vezérkar átszervezéséről rendelkeztek. Az átszervezés részleteit a MPRI szakértőinek segítségével dolgozták ki, ezért az elképzelések amerikai mintákat tükröztek, a védelmi minisztériumon belül például a Pentagon mintájára nyolc főosztályt alakítottak ki (Vankovska 2002, 82-83, Cehulic és Vukadinovic 2001, 72-73, Edmunds 2007, 197).

A minisztérium első átfogó (mint említettem, kudarcot vallott) reformkísérletére a Šušakot a tárca élén váltó Andrija Hebrang minisztersége alatt került sor. Hebrang programja előirányozta a még 1997-ben elnöki rendeleti szinten elrendelt békeidőbeli struktúra kialakítását, a haderő és a minisztérium demokratikus kontrolljának erősítését, a tárca müködésének átláthatóbbá tételét, felhalmozott adósságának csökkentését és a tetemes beszállítói tartozások kiegyenlítését is. Különös hangsúly kapott volna a minisztérium beszerzéseinek és gazdálkodásának racionalizálása, beleértve a hozzá tartozó gazdasági társaságokat, például az RH Alan vállalatot, amely a fegyverek és hadianyagok export-importjáért volt felelős (Cehulic és Vukadinovic 2001, 83-84, Mihaljevic 2012, 139-140)

A tervezett reformok nem csak a hercegovinai horvátok finanszírozását biztosító csatornákat, és a minisztérium ezen a téren játszott szerepét érintette volna (melynek fenntartása a „hercegovinai csoport” életbe vágó politikai érdeke volt), de megkérdőjeleződött volna az irányítási modell, melyet Tudjman és Šušak épített fel, és ami ez idáig jellemezte a védelmi tárca müködését. Ezen modell fő jellemzői az informális struktúrák használata, az átláthatóság és az elszámoltathatóság hiánya voltak (Mihaljevic 2012, 139-140, International Crisis Group 1998, 7-9).

A tárca pénzügyeinek rendbe tétele, a pazarló gazdálkodás megszüntetése ugyanakkor gazdasági érdekeket is sértett. A Védelmi Minisztérium a HDZ klientúrája számára egyfajta „kifizetőhelyként” funkcionált: a kormánypárthoz közeli 
vállalkozók gyakran jutottak kedvező megrendelésekhez, üzleti lehetőségekhez a tárca révén (Mihaljevic 2012, 138, Bellamy 2003, 188-189). Mint Edmunds (2007, 141) megemlíti, a hadsereg és a minisztérium vezetői a 66. mérnök ezredet gyakorlatilag építőipari vállalatként használták.

Érdemes megemlíteni, hogy a minisztérium átalakítása körüli vita egyik szereplőjét, az RH Alan vállalatot vezető Zagorecet már jóval a Tudjman-rezsim bukását követően, 2010-ben sikkasztásért és hivatali visszaélésért börtönbüntetésre ítélték (Vecernji List 2017, Economist Intelligence Unit 2009, 10).

Az időszak második felében a védelmi költségvetés terén tett korlátozott átalakítások is elsősorban a nemzetközi nyomásgyakorlás hatására történtek (a védelmi szektor gazdálkodásának átláthatóbbá tétele a NATO Békepartnerségi programjához történő csatlakozás egyik feltétele volt). Ezen intézkedések egy része ugyanakkor részben ismételten csak formális vagy „kozmetikai” jellegü volt: a boszniai horvátoknak folyósított pénzügyi támogatás egy részét ezt követően a védelmi minisztérium helyett a pénzügyminisztérium kezelte. (Cehulic és Vukadinovic 2001, 81-82).

Stratégiai jellegü, a biztonság- és védelempolitika alapvető irányait lefektető stratégiai dokumentumok ebben a periódusban sem születtek. Noha az MPRI közremüködésével kidolgoztak egy védelmi Fehér Könyvet (white paper), valamint egy védelmi stratégiát, de ennek elfogadására végül nem került sor (Tatalovic 2010, 10, Cehulic és Vukadinovic 2001, 75-76, Vankovska 2002, 83).

Hasonlóan az előző időszakhoz, a parlament és a fegyveres erökkel kapcsolatban illetékes belügyi és nemzetbiztonsági bizottság szerepe igen korlátozott, vagy csak névleges volt a haderő feletti kontroll területén. Mivel a kormányzat megpróbálta „eltusolni” a HDZ „mérsékelt” politikusainak a katonai hírszerzés (SIS) általi lehallgatását, annak ellenére, hogy a megfigyelés ténye nyilvánosságra is került, az ellenzéki képviselők 1998 őszén lemondtak a bizottságban vállalt tisztségükről (Lozancic és Burdelez 1998, 52, Economist Intelligence Unit 1998b, 11).

\subsubsection{A védelmi szféra nemzetközi dimenziója}

Nemzetközi szempontból az 1995 és 1999 közötti időszak két alapvető jellemzőjét emelhetjük ki. Egyfelől, noha a horvát kormány többször hangsúlyozta, alapvető politikai célja a NATO-hoz való közeledés, az ehhez füződő feltételeket nem kívánta teljesíteni (Tatalovic 2010, 7, Simunovic 2015, 192-193). Másfelől, a kormányzat 
élesen elzárkózott minden, a nemzetközi közösség által szorgalmazott, a volt Jugoszlávia utódállamai közötti regionális együttmüködési kezdeményezéstől, arra hivatkozva, hogy ezek az országot „vissza akarják kényszeríteni a Balkánra” (Razsa és Lindstrom 2004). Az időszak kezdetén meglévő, 1994-1995-re visszanyúló jó horvát-amerikai kapcsolatok Washington számára azonban nem jelentették azt, hogy kritikátlanul viszonyult volna a tudjmani Horvátországban tapasztalható autoriter tendenciákhoz (melyeket a „zágrábi válság” illusztrált a legjobban), vagy a horvát kormány kevéssé konstruktív magatartásához a daytoni megállapodással, illetve a hágai törvényszékkel (ICTY) kapcsolatban (Cehulic és Vukadinovic 2001, 69-70). Így amikor Mate Granic külügyminiszter 1997 májusában benyújtotta Horvátország csatlakozási kérelmét a NATO Békepartnerségi (PfP) programjához, az amerikai kormány konzekvensen azt az álláspontot képviselte, hogy Horvátországnak a NATO PfP-hez való csatlakozására csak bizonyos alapvető politikai feltételek teljesítése esetén kerülhet sor. Az említett feltételek közül a legfontosabbak a szerb menekültek visszatérésének elősegítése, a daytoni békemegállapodás betartása (különösen a Herceg-Boszna államalakulat politikai és pénzügyi támogatásának megszüntetése), valamint a választási eljárás reformja és a média feletti kormányzati nyomásgyakorlás csökkentése voltak (Edmunds 2007, 192-193, Montgomery 1998, 88-90). Mivel az említett követelmények - idővel fokozódó mértékü - ellenállást váltottak ki a tudjmani vezetésből, az időszak végéig Horvátország kimaradt a nemzetközi védelmi együttműködés multilaterális formáiból, így például a NATO Békepartnerségi programjából is. Ilyen együttmüködésre tehát 1995 és 1999 között csak kétoldalú keretek között került sor, vagy kormányközi csatornákon keresztül, vagy olyan közvetett módon, mint az MPRI katonai magáncég igénybevétele (Bellamy 2002, 189, Edmunds 2007, 192-193, 198-199, Tatalovic 2010, 7).

Az MPRI céggel történő együttmüködés, mely, mint említettem, 1994-ben kezdődött, az 1995 utáni periódusban kibővült. Az 1996-ban és 1998-ban meghosszabbított demokratikus átmenetet támogató program (Democratic Transition Assistance Program, DTAP) alapvetően képzési-kiképzési jellegü volt, a szervezet képzéseket dolgozott ki és tartott a demokratikus civil-katonai kapcsolatok terén a hadsereg személyi állománya számára, közremüködött a Garmisch-Partenkirchenben található George Marshall Centerbe kiküldendő horvát tisztek és minisztériumi tisztviselők kiválasztásában és felkészítésében, valamint javaslatokat dolgozott ki a katonai oktatás és képzés meglévő rendszerének továbbfejlesztése. Az 1995-től 1999-ig futó 
hosszú távú igazgatási program (Long Range Management Program) a horvát védelmi minisztérium átszervezésére, valamint egy védelmi Fehér Könyv, illetve más stratégiai dokumentumok elkészítéséhez nyújtott tanácsadásra irányult (Vankovska 2002, 71). A MPRI-vel való együttmüködés teljes időtartama alatt a szervezet megbízási díjait a horvát kormány finanszírozta, mely becslések szerint összesen kb. 40 millió dollárba került Zágráb számára (Vankovska 2002, 78).

Mint fentebb már említést tettem róla, a szervezet által javasolt megoldások esetenként a vonatkozó amerikai modellek és megoldások mechanikus átvételét jelentették (például a horvát védelmi minisztérium belső átszervezése a Pentagon mintájára), helyi szakértők bevonására csak akkor került sor, ha bebizonyosodott, hogy a MPRI által javasolt intézkedések gyakorlati megvalósítása nem lehetséges (Edmunds 2007, Vankovska 2002, 82-83). A javasolt megoldások esetenként azért nem voltak megvalósíthatóak, mert nem vették figyelembe a horvátországi katonai és politikai realitásokat, vagy gazdaságilag túl költségesek voltak. A tiszthelyettesek (non-commissioned officers) szerepére a MPRI programjaiban és javaslataiban helyezett túlzott hangsúly például egyértelmüen az amerikai hadsereg szemléletmódját tükrözte és nem illeszkedett a horvátországi katonai hagyományokhoz sem. Más esetekben a szervezet javaslatainak végrehajtása a rendszer autoriter jellege miatt nem volt lehetséges. Biljana Vankovska arra utal, hogy a MPRI tevékenységének kevéssé hatékony volta és magas költségei ellenére a horvát kormány részben egyfajta „bürokratikus tehetetlenség” miatt, részben pedig azért hosszabbította meg többször is szerződését a céggel, mert az MPRI-ra a zágrábi döntéshozók alapvetően az amerikai kormány nem hivatalos képviselőjeként tekintettek, vagy hogy az amerikai tanácsadókra hivatkozva „legitimálja” az ezen a területen folytatott politikáját (Vankovska 2002, 83).

A közvetett csatornákon (MPRI) kívül 1995-től a horvát kormányzat az amerikai kormány hivatalos programjain keresztül és részesült védelmi támogatásban, elsőként az IMET (International Military Education and Training) programon keresztül. Miután az Európai Unió 1998-ban feloldotta a Horvátországnak nyújtott védelmi együttmüködésre vonatkozó korlátozásokat, a NATO európai tagállamai, mint például Németország, Franciaország és Nagy-Britannia is nyújtottak hasonló oktatási-képzési támogatást a horvát hadsereg, illetve személyzete számára (Bellamy és Edmunds 2005, 73, 85-86, Wheaton 2000, 69). Annak ellenére, hogy autoriter politikai gyakorlata, illetve a daytoni békeszerződéssel, vagy a hágai törvényszékkel 
kapcsolatos magatartása miatt 1998-1999-ben a Tudjman-rezsim növekvő mértékben izolálódott, a hadseregek közötti együttmüködés (military to military cooperation) fenti formái azon kevés területek közé tartoztak, ahol tovább folytatódott a nemzetközi kooperáció (Wheaton 2000, 70).

Horvátország az első között támogatta a NATO koszovói légiháborúját és járult hozzá légterének erre a célra való használatához. Ez a horvát magatartás szerepet játszott abban, hogy 1999 tavaszán az amerikai kormány bizonyos korlátozott engedményeket tett: például áprilisban engedélyezte, hogy amerikai vállalatok Horvátországnak fegyvereket adjanak el (Economist Intelligence Unit 1999, 14).

\subsubsection{A magyarázó tényezők hatásának értékelése}

A történelmi örökség szerepe terén az előző alfejezetben elmondottak nagyobb részben az 1995 és 1999 közötti periódust illetően is érvényesnek tekinthetőek Ezen túlmenően Stjepan Domjančić $(2015,171)$ szerint a JNH és a Horvát Hadsereg, illetve a tudjmani Horvátország és a titói Jugoszlávia közötti hasonlóság egyfajta „emlékezetpolitikai” szempontból is megfigyelhető. Ahogyan a jugoszláv periódusban a partizánháború az állami propaganda által teremtett „mítoszának” a JNH volt az igazi letéteményese, a Honvédő Háború, mint a tudjmani rendszer egyfajta „eredetmítosza”, legfontosabb legitimációs alapja összekapcsolódott a horvát hadsereggel.

A háború lezárultával a fenyegetés-környezet hatása némileg gyengült, de teljesen nem szünt meg. Egyfelől a milosevicsi Szerbiát Horvátország továbbra is katonai fenyegetésnek tekintette (ld. Bellamy és Edmunds 2005, 78), másfelöl, ebben az időszakban is találkozhatunk a háború, illetve a biztonsági fenyegetés politikai eszközként történő felhasználásával is. Az 1996-os parlamenti választást azzal a szándékkal hozta elöre a HDZ vezette kormányzat, hogy politikai tőkét kovácsoljon a krajinai szerbek feletti 1995 nyári katonai győzelemből (Soberg 2007, 46, Dolenec 2013, 135), az ún. „zágrábi válság” során pedig Tudjman a folytatódó balkáni instabilitással és Nyugat-Szlavónia még folyamatban lévő reintegrálásával indokolta, hogy miért nem engedheti meg az ellenzéki pártok hatalomra kerülését a horvát fővárosban (Bellamy 2002, 181-182).

A belső politikai környezet hatásait illetően az 1991 és 1995 közötti periódusnál írottak nagyobb része jelen időszakra is érvényesnek tekinthető, mivel a 
hatalomgyakorlás alapvető paraméterei és módszerei nem változtak, a változások inkább formális jellegünek tekinthetőek, így például az aktív állományú katonák politikai tevékenységének bizonyos korlátok közé szorítása (Mihaljevic 2012, 137).

A vizsgált időszakban egy olyan reformkísérletre került sor, mely érdemben befolyásolta volna a fegyveres erők felügyeletének kereteit (Hebrang tervezett intézkedései), de mivel a reform végrehajtása jelentős politikai és gazdasági érdekeket sértett volna, az érintettek (beleértve áttételesen magát Tudjmant is) eredményesen tudtak fellépni a reform blokkolása és Hebrang a minisztérium élen történő ellehetetlenítése érdekében (International Crisis Group 1998, 9).

A Tudjman-rezsim fennállásának utolsó két évében nem csak a kormányzó párt vesztette el támogatottsága jelentős részét, hanem a különböző korrupciós botrányokkal, visszaélésekkel kapcsolatba hozott hadsereg addig igen magas társadalmi elfogadottsága is megrendült. Ez a tény, valamint az, hogy a katonaság a tudjmani érában sosem volt autonóm politikai szereplő, magyarázzák alapvetően, hogy az államfő halálát és pártjának választási vereségét követően fel sem merült a katonai vezetés részéről a politikába való beavatkozás annak érdekében, hogy megakadályozzák a rezsim bukását (Bellamy 2003, 194, Edmunds 2007, 57-58).

Mivel az 1995 és 1999 közötti időszakban nem járt sikerrel a horvát kormány azon törekvése, hogy az ország a NATO Békepartnerségi (PfP) programjának tagjává váljon (Bellamy 2002, 189), a nemzetközi szereplők hatása az előző periódushoz hasonlóan csak bilaterális csatornákon keresztül jelentkezett. Mint említettem, a védelmi minisztérium átszervezésére a MPRI szakértőinek közreműködésével, amerikai minták alapján került sor. Emellett az MPRI, illetve több NATO tagállam szervezett a hadsereg személyzete számára különféle képzési programokat.

Eltérően értékelhető, hogy ezen programok mennyire gyakoroltak hatást a civilkatonai kapcsolatokra egyéni és szervezeti szinten. Egyéni szinten ezen minden bizonnyal valamilyen mértékben hozzájárultak a demokratikus civil-katonai kapcsolatokra vonatkozó elképzelések elterjesztéséhez, valamint a NATO-val való „Szellemi interoperabilitás” (Simunovic 2015, 193) megteremtéséhez is (Wheaton 2000, 70-71). Azon törekvések, melyek azonban a demokratikus kontroll és civilkatonai kapcsolatok terén szervezeti szintü változásokra törekedtek, az autoriter jellegü politikai hatalomgyakorlás körülményei nem jártak sikerrel (Edmunds 2007, 192-193). 


\subsection{A civil-katonai kapcsolatok demokratizálása Tudjman után (2000-2003)}

\subsection{1. Általános politikai trendek}

A 2000 januári és februári, az ellenzék győzelmével záruló parlamenti- és elnökválasztás utáni időszak alapvetően több, egymással esetenként ellentétes folyamattal jellemezhető. Az Ivica Račan vezette balközép koalíciós kormány részéről egyértelmüvé vált a politikai szándék, hogy Horvátország az euroatlanti integrációs intézmények tagjává kíván válni, és kész ennek érdekében a nemzetközi szervezetek által szabott feltételeket is teljesíteni (Edmunds 2007, 194, IMO 2011, 19-20, Tatalovic 2010, 18). Az új kormány tudatában volt annak is, hogy a horvát haderő átalakítása nem csupán az euroatlanti integráció miatt szükséges: figyelembe véve az ország gazdasági teherbíró képességét, különösen az 1990-es évek végi gazdasági válság körülményei között, a hadsereg és a védelmi apparátus mérete gazdaságilag fenntarthatatlan volt, és nem felelt meg a változó stratégiai helyzetnek sem (Edmunds 2003, 37-38, Edmunds 2007, 128, Bellamy 2002b, 165-166).

Az adott helyzetben elkerülhetetlen nagy arányú katonai létszámcsökkentés azonban az akkoriban igen magas horvátországi munkanélküliség körülményei közepette, illetve a tiszti és főtiszti állomány nagyobb részének HDZ-kötődése, valamint a szintén HDZ-hez köthető veteránszervezetek és maga a jobboldali ellenzék éles kritikái miatt szociális és politikai szempontból is nehezen volt kivitelezhető (Watkins 2004, 6, Edmunds 2007, 132-133, Bellamy és Edmunds 2005, 78).

A változtatások végrehajtásának módját illetően azonban a kezdetben hat pártot magába foglaló kormánykoalíció nem volt egységes. Különösen éles politikai viták folytak egyebek mellett az elnöki hatáskörök meghatározása vagy a titkosszolgálatok demokratikus felügyelete kérdésében. A védelmi szférában a súlyos belső viták miatt a tervszerü szakpolitika-formálást megnehezítette, hogy eltérő pártból került ki a köztársasági elnök (Stjepan Mesić), a miniszterelnök (Ivica Račan), valamint a védelmi miniszter (Jozo Radoš), így az időszak első két évében, a 2002 nyári kormányátalakításig az ezen a területen elért eredmények korlátozottak voltak (Watkins 2004, 3, Edmunds 2003, 16-17, 74, Edmunds 2007, 59-60, 75, Bellamy és Edmunds 2005, 75-76). A védelmi reformok felgyorsítására csak Ivica Račan második kormánya (2002-2003) idején került sor, amikor a védelmi tárcát a kormányfő pártjából érkezett Željka Antunović vette át, aki egyben miniszterelnök- 
helyettesi pozíciót is betöltött (Edmunds 2007, 60).

Hasonló "kettősség" volt megfigyelhető a nemzetközi közösséggel való együttmüködés területén is. Noha mint említettem, az új kormány elkötelezte magát az ország euroatlanti integrációja mellett, és ezen a területen az időszakban bizonyos sikereket is elkönyvelhetett (2000 májusában Horvátország a NATO Partnerség a Békéért programjának tagja lett, 2002 májusában pedig meghívták a NATO MAPba), a volt Jugoszlávia területén elkövetett bünöket vizsgáló hágai törvényszékkel (ICTY) való együttmüködés kérdése folyamatos politikai vitákra adott okot (Edmunds 2003, 62, Edmunds 2007, 198-199, 202-203).

Annak ellenére, hogy a nemzetközi közösség, így a NATO is kezdettől egyértelművé tette, hogy az euroatlanti integrációs intézményekhez való csatlakozás feltétele a Hágával való kielégítő együttműködés, a 2000 utáni időszakban Horvátország egyfajta „húzd meg, ereszd meg” politikát folytatott az ICTY-t illetően: jelentős lépésekre (például Ante Gotovina tábornok kézre kerítése ügyében) csak többszöri és eröteljes nemzetközi nyomásgyakorlást követően vagy akkor került sor, amikor az adott lépés már kevésbé volt politikailag költséges (Szilágyi 2003, 3-4, Edmunds 2003, 62-63).

Mint az előző alfejezetben említettem, a katonaság nem tett kísérletet arra, hogy megakadályozza a Tudjman-rezsim bukását az államfő halála és a HDZ választási veresége után. Ennek ellenére a horvát hadsereg személyi állományának nagyobb része, különösen a tiszti és fötiszti rendfokozatúak, továbbra is egyértelmüen HDZszimpátiákkal rendelkeztek, és kezdetben az új politikai vezetőkkel való együttmüködés nem volt problémamentes. Az új kormány intézkedései közül különösen pedig az ICTY-vel kapcsolatos kormányzati politika váltott ki ellenérzéseket a hadsereg tagjaiból, mivel a horvátországi háborús eseményekkel kapcsolatban vád alá helyezett katonai vezetők esetleges kiadatását a „Honvédő Háború" megkérdőjelezéseként értékelték (Edmunds 2007, 58, 62-63). A 2000-ben és 2001-ben tapasztalható civil-katonai feszültségek és súrlódások közül a legkomolyabb az ún. „tábornokok levele” incidens volt, mely szintén a Hágával való együttműködéshez kapcsolódott. Miután 2000 szeptemberében 12 háborús bünökkel gyanúsított személyt, közöttük két tábornokot vettek őrizetbe a horvát hatóságok, a horvát fegyveres erők hét aktív és öt nyugállományú tábornoka nyílt levelet intézett Stjepan Mesić elnökhöz, melyben élesen bírálták az elnök és a kormány politikáját, illetve azzal vádolták Mesićet hogy rágalmazza a horvátországi háború hőseit. 
Az államfo, élve alkotmányos jogosítványával azonnali hatállyal nyugállományba helyezte a levelet aláíró hét aktív tábornokot, közöttük Ante Gotovinát is. Ennek kapcsán Mesić utalt arra is, hogy az új kormány alatt nem lesz elfogadható az aktív állományú tisztek nyílt politikai tevékenysége (Edmunds 2007, 62-63, Lukic és Morel 2002, 34). A „tábornokok levele” -ügyben meghozott államfői intézkedés precedenst teremtett a haderő demokratikus politikai kontrollja területén, így annak érdemi megkérdőjelezésére a továbbiakban már nem került sor (Edmunds 2007, 62). A haderő politikai irányítására vonatkozó politikusok közötti vitákkal párhuzamosan a vezérkaron és a minisztériumon belül folyt egy olyan szakpolitikai jellegü vita is, mely a horvát haderő jövőbeni célkitűzéseire és orientációjára vonatkozott. Mint ahogyan az új kormány időszakában elfogadott stratégiai dokumentumokból, így a Nemzeti Biztonsági Stratégiából (lásd a következő alfejezetben) is kitünik, az euroatlanti integrációs célkitüzésekkel összhangban a horvát hadsereget a döntéshozók a kollektív biztonsági felfogásnak megfelelően szerették volna átalakítani, mely egy kisebb létszámú, mozgékonyabb, és legalább részben külföldi (out-of-area) bevetésre alkalmas haderőt feltételez (Simunovic 2015, 193).

Részben a (jugoszláv) történelmi örökség, részben a horvátországi háború tapasztalatai miatt a védelmi apparátus azonban koncepcionálisan erősen kötődött a területvédelmi logikához, ezért a vezérkar egy része meglehetősen szkeptikusan fogadta a létszámleépítésre valamint a hadsereg strukturális átalakítására vonatkozó kormányzati terveket. A katonai vezetők egy része arról sem volt teljesen meggyőződve, hogy a Milosevics-rendszer 2000 öszi bukását követően véglegesen megszünt a szerb katonai fenyegetés (Bellamy 2003, 199, Bellamy és Edmunds 2005, 78). Noha a Račan-kormányzat alatt megkezdett szerkezeti reformok a fentebb említett kollektív biztonsági felfogás irányába mutattak, a horvát haderő általános orientációjáról szóló szakmai és politikai vita ebben az időszakban azonban nem zárult le.

\subsubsection{Jogi-intézményi és szervezeti változások}

A jogi környezet szempontjából a legnagyobb jelentősége a 2000 őszi alkotmánymódosításoknak volt, melyek félelnökiről parlamentire változtatták Horvátország kormányformáját. Noha az ellenzék körében a választást megelőzően konszenzus volt arról, hogy az államföi hatáskörök csökkentése szükséges, mind a 
módosított alkotmány, mind pedig a később (2002 márciusában) elfogadott új honvédelmi törvény olyan, a kormányzó pártok közötti kompromisszum eredménye, mely több fontos jogkört is az elnök kezében hagyott (Edmunds 2007, 59-60 Edmunds 2003, 16, Bellamy és Edmunds 2005, 77). A kialakított alkotmányos keretek között megnőtt a jelentősége a kormány és az államfő közötti együttmüködésnek, így különösen a „politikai társbérlet” (kohabitáció), de akár az azonos párthoz vagy pártkoalícióhoz tartozó köztársasági elnök és kormányfö, illetve védelmi miniszter közötti politikai viták jelentősen megnehezíthették a hatékony szakpolitikai döntéshozatalt (Edmunds 2003, 16, Volten 2005, 47-48).

A 2000 őszi alkotmánymódosítások közül a fegyveres erők demokratikus kontrollja szempontjából a 101. és a 106. cikk reformja tekinthető a legfontosabbnak. Az új 101. cikkely szövege szerint az államfő csak hadiállapot idején jogosult önállóan törvényerejű rendeletek kibocsátására. Amennyiben hadiállapot nem, de az ország függetlenségére és területi integritására irányuló fenyegetés esete áll fenn vagy az államszervezet alkotmány szerinti normális müködése nem lehetséges, az államfő törvényerejü rendeleteket csak miniszterelnök javaslatára, annak ellenjegyzése mellett adhat ki. Mindkét esetben szükséges a rendeletek utólagos megerősítése a horvát parlament által (Constitution of the Republic of Croatia 2014, Art. 101.). A 106. cikkely szerint az államfő saját hatáskörében tanácsadó testületeket állíthat fel, melyek tagjait saját maga nevezheti ki vagy mentheti fel. A tanácsadó testületek működése azonban nem sértheti a hatalmi ágak szétválasztásának elvét (Constitution of the Republic of Croatia 2014, Art. 106.). A két említett cikkely módosításával az új kormányzat elejét kívánta venni annak a Tudjman-rezsim idején jellemző gyakorlatnak, amikor az egykori államfó a korábbi 101. cikkelyt használta fel a kormány és a parlament megkerülésére a fegyveres erők és a titkosszolgálatok irányítása terén, illetve olyan testületeket hozott létre, mint például a Védelmi és Nemzetbiztonsági Tanács (VONS), melyek a védelmi szféra területén gyakorlatilag átvették a kormány szerepét a döntéshozatalban (Grubisa 2003, 21-22, Edmunds 2007, 54-55).

Annak ellenére, hogy az alkotmány módosítására a kormányzó pártok és az államfó megállapodása alapján gyorsan sor került, illetve Stjepan Mesić intézkedett a VONS, továbbá a korábban csak az elnöknek felelős, a hadsereg parancsnoki láncán kívül álló 1. Gárdaezred feloszlatásáról, a kormány és Mesić kapcsolata a védelmi szférát illetően továbbra is konfliktusokkal terhelt volt. Az államelnök például a saját 
személyes választottját, Petar Stipetić tábornokot nevezte ki vezérkari főnöknek a kormányfővel vagy a védelmi miniszterrel való konzultáció nélkül. Az államfő és a védelmi miniszter, Jozo Radoš között mélyülő politikai konfliktusban Radoš környezete azzal próbálta meg Stipetić tábornokot lejáratni, hogy azt terjesztették, háborús bünök miatt Hágában vádat fognak emelni ellene. (Grubisa 2003, 22, Edmunds 2003, 18, Bellamy és Edmunds 2005, 77, 83). Stipetić viszont azzal vádolta a Radoš vezette tárcát, hogy a katonai hírszerzés a miniszter utasítására őt és Mesićet is megfigyelés alá helyezte (Edmunds 2007, 60). A kormánykoalíció belső vitái, illetve az államfó és a kormány közötti politikai szembenállás is magyarázta, hogy az új honvédelmi törvény, illetve az ország NATO-integrációja szempontjából is fontos Nemzeti Biztonsági Stratégia és Védelmi Stratégia elfogadására egészen 2002 márciusáig kellett várni (Edmunds 2007, 60).

$\mathrm{Az}$ ekkor elfogadott új honvédelmi törvény a fegyveres erők irányításával kapcsolatos hatásköröket az államfö, a kormány és a parlament között megosztotta, és a horvát államelnök ezt követően is több védelmi szférát érintő hatáskörrel rendelkezett, mint az a legtöbb parlamentáris kormányformájú államban megszokott. A 2002-es honvédelmi törvény 7. paragrafusa 22 államföi hatáskört sorolt fel: az elnök például kibocsátja a Nemzeti Katonai Stratégiát, dönt a hadsereg területi szervezetéről, a kormány javaslatára kinevezi és felmenti a vezérkari főnököt, a vezérkari főnök előterjesztése alapján, a védelmi miniszter egyetértése mellett kinevezi és felmenti a tábornokokat, illetve véleményezi a védelmi miniszterjelölt személyét (Grubisa 2003, 24-25).

A vezérkari főnököt jogállását illetően a törvény az államfő alá rendelte, a törvényből azonban világosan nem derült ki, hogy milyen jogi viszony van a vezérkari főnök és a védelmi miniszter között, illetve a feladat- és hatáskörök területén is átfedés tapasztalható (Grubisa 2003, 33-34). Hasonlóképpen, míg a katonai vezetők kinevezése és felmentése a kormány (védelmi miniszter) és az államfö között megosztott jogkör, ezzel ellentétben a hadsereg és a védelmi minisztérium adminisztratív és pénzügyi irányításához kapcsolódó hatásköröket a törvény többségében a kormányhoz telepítette. A létrejött jogi struktúra tehát feltételezte az államfő és a kormány, illetve a parlamenti többség közötti jó együttműködést (Grubisa 2003, 27-28, 31-32, Edmunds 2007, 59-60).

A hadüzenet és békekötés jogán, valamint a horvát fegyveres erők országhatáron kívüli bevetéséröl való döntésen túl a parlament fő jogkörei közé tartozik a Nemzeti 
Biztonsági Stratégia és a Védelmi Stratégia, valamint a haderő hosszú távú fejlesztési programjának elfogadása, a Védelmi Minisztérium éves jelentésének megvitatása és elfogadása, illetve véleménynyilvánítás a vezérkari fönök kinevezéséről és felmentéséről. Értelemszerüen a törvényhozás hatáskörébe tartozik a katonai költségvetés (az állami költségvetés részeként történő) elfogadása is (Cvrtila 2003, 42-44). Ebben az időszakban a horvát parlament, a Sabor katonai ügyekben illetékes szakbizottsága a Belügyi és Nemzetbizottsági Bizottság (OUPNB) volt, melynek illetékességi köre azonban magába foglalta a titkosszolgálatokat és a rendőrséget is. A hatékony parlamenti felügyelet ellátását azonban a képzett támogató személyzet, illetve a képviselők katonai és védelmi ügyek iránti csekély érdeklődése mellett az is gátolta, hogy a bizottság tagjainak munkájában a pártfegyelem játszott elsődleges szerepet (Edmunds 2003, 21-22). Vladko Cvrtila szerint azonban a bizottság munkája javult a 2002 előtti állapothoz képest, és az az év tavaszán elfogadott törvénycsomag, illetve a Nemzeti Biztonsági és a Védelmi Stratégia vitájában a bizottság aktív szerepet játszott (Cvrtila 2003, 51-52).

A 2002 márciusi törvénycsomag részét képezte még a katonai szolgálati jogviszonyról szóló törvény módosítása, mely megtiltotta az aktív állományú katonáknak a politikai tevékenységet, valamint a fegyveres erők, a rendőrség és a polgári védelem nemzetközi müveletekben való részvételét szabályozó törvény is (Tatalovic 2004, 71, Cvrtila 2003, 50).

A védelmi tárgyú törvénycsomaggal egy időben, 2002 márciusában fogadták el Horvátország történetének első Nemzeti Biztonsági Stratégiáját és Védelmi Stratégiáját is. Érdemes megemlíteni, hogy eredetileg egy külső szakértői csoportot bíztak meg a két stratégia alapjául szolgáló háttértanulmányok elkészítésére, azonban a szakértők jelentését a közöttük és a minisztérium közötti vita miatt végül nem használták fel, a parlament által elfogadott stratégia a minisztérium apparátusa által, rövid idő alatt került kidolgozásra (Mahecic 2009, 32, Pietz és Remillard 2006, 36).

Az új Nemzeti Biztonsági Stratégia két alapvető premisszára épült: az Európai Unióhoz és a NATO-hoz való csatlakozás, mint az ország stratégiai célja, és a megváltozott regionális környezet, melynek következtében már nincs olyan „kitüntetett” állam, mely Horvátország biztonságát és szuverenitását fenyegetné, mint amilyen kis-Jugoszlávia volt a milosevicsi rendszer időszakában (Szilágyi 2003, 6-7, Radicevic 2003, 176-178).

A dokumentum szerint az instabilitás egyik lehetséges forrása továbbra is Bosznia- 
Hercegovina, ahol a központi hatalom nem müködik megfelelően és nem kielégítően rendezett az ottani horvát népesség helyzete sem (Strategija nacionalne sigurnosti RH 2002, 6. pont). Ugyanakkor lehetséges fenyegetésként szerepel a balkáni helyzet újabb destabilizálódása, például megoldatlan határviták vagy kisebbségi konfliktusok miatt (Strategija nacionalne sigurnosti RH 2002, 27, 31-32. pont).

A lehetséges biztonsági fenyegetések között azonban megjelenik a nemzetközi terrorizmus, valamint olyan új típusú biztonsági kihívások is, mint a nemzetközi szervezett bünözés vagy a tömeges menekültválságok (Strategija nacionalne sigurnosti RH 2002, 11-12, 33-34. pont). A fegyveres erőket illetően a dokumentum megállapítja, hogy új feladatokra kell felkészülnie a horvát haderőnek, egyebek mellett a különbféle nemzetközi müveletekben való részvétel terén, illetve általánosságban a haderő fejlesztésére az ország integrációs célkitüzéseivel összhangban kell, hogy sor kerüljön (Strategija nacionalne sigurnosti RH 2002, 78, 80. pont). Az új feladatok között azonban a stratégia említi az olyan „nem tradicionális" feladatköröket is mint például a civil intézmények támogatása a katasztrófavédelem, a terrorizmus vagy a szervezett bünözés elleni harc területén (Strategija nacionalne sigurnosti RH 2002, 79. pont).

A Nemzeti Biztonsági és a Védelmi Stratégiát egy évvel később a Nemzeti Katonai Stratégia elfogadása követte, melyet a hatályos törvényi elöírásoknak megfelelően a vezérkar dolgozott ki és az államfó léptetett életbe (Bellamy és Edmunds 2005, 74).

A szervezeti átalakitás terén az új kormányzat alapvetően négy fontos feladattal szembesült: a hadsereg depolitizálása, a védelmi minisztérium civilesitése, a korrupció és a tárca pazarló gazdálkodásának felszámolása, valamint a minisztérium és a hadsereg átszervezése és létszámleépitése. A depolitizáció terén a fö kihívást az jelentette, hogyan lehetséges a korábbi HDZ-rezsimhez kötődő személyes hálózatok felszámolása a minisztériumban és a hadsereg vezetésében anélkül, hogy „repolitizációra” azaz a HDZ pártpolitikai befolyásának az új kormányzó pártok klientúrájával való felváltására kerülne sor. A balközép kormánykoalíció egyes kritikusai szerint Jozo Radoš vezetése alatt érdemben nem csökkent a haderő és a minisztérium köztisztviselői apparátusának átpolitizáltsága, fontos kinevezésekre továbbra is pártpolitikai alapon került sor, melyet tovább fokozott a koalíció sokpárti jellege (Edmunds 2007, 65, Bellamy és Edmunds 2005, 75-76).

A minisztérium civilesitése terén felmerülő problémák hasonlóak voltak azokhoz, melyek a korábbi szovjet szatellitállamokban voltak tapasztalhatóak a rendszerváltást 
követően. A Tudjman-érában a minisztérium személyzetének többsége aktív állományú katona volt, a védelmi miniszteren és helyettesén kívül a tárca vezetői, így a helyettes államtitkárok is a katonák közül kerültek ki (Grubisa 2003, 30, Mahecic 2003, 59). Hasonlóképpen a korábbi Varsói Szerződés tagállamaihoz a rendszerváltást követően, a kétezres évek elején Horvátországban kevés volt a katonai-védelmi kérdések terén felkészült civil szakember, a minisztériumi kinevezések politikai jellege miatt pedig a gyakori személycserék tovább fokozták ezt a problémát (Edmunds 2003, 20-21).

A kezdeti reformok közül viszonylag sikeresebbek voltak azon intézkedések, melyek a korrupció és a pazarló gazdálkodás felszámolására irányultak. Ellentétben a rendőrséggel, ahol a korrupció a hivatali hierarchia alacsonyabb szintjein is jelen volt, a védelmi tárcánál és a hadseregnél a korrupt gyakorlatok leginkább annak korábbi vezetésére voltak jellemzők. Az olyan lépések, mint például a minisztérium autóflottájának és a minisztériumi vezetők költségtérítéseinek felülvizsgálata, vagy a tárca számára kedvezőtlen beszerzési szerződések felmondása, ugyanakkor nem voltak alkalmasak azon strukturális problémák megoldására, melyek a minisztérium és a hadsereg túlméretezett jellegéből fakadtak (Edmunds 2007, 141, Bellamy 2002 182-183, Bellamy és Edmunds 2005, 79).

A Tudjman utáni „rezsimváltás” időszakában a horvát haderő létszáma 55-61 ezer före volt tehető, amelyből kb. 24.000 fő volt sorkatona, míg a minisztérium létszáma még 2002 közepén is meghaladta a 4000 föt (Cehulic és Vukadinovic 2001, 75-76, Edmunds 2007, 132, Stanicic 2003, 4). Az új kormányzat számára kezdettől fogva világos volt, hogy a kilencvenes évek magas katonai kiadásai gazdaságilag nem fenntarthatóak és nem is indokoltak az ország megváltozott nemzetközi helyzetének fényében (Edmunds 2007, 127-128). 2000 és 2002 között jelentősen, a GDP körülbelül 2,5\%-ára csökkentették a katonai költségvetést, azonban a szerkezeti reformok (leginkább a jelentős létszámcsökkentés) halogatása miatt a védelmi kiadásokon belül tovább nőtt a bér jellegü költségek korábban is túlzottan magas szintje. (Edmunds 2003, 40, Edmunds 2007, 132-133) A hivatásos katonák azonnali drasztikus létszámcsökkentése azonban politikailag nehezen volt vállalható: az országban ez idő tájt $20 \%$ feletti volt a hivatalosan mért munkanélküliség, több fejletlen régióban a katonaság számított az egyik legfontosabb munkáltatónak, valamint a hivatásos katonák nagyobb része a horvátországi háború korábbi résztvevője volt, az ellenzéki HDZ és a hozzá köthető veteránszervezetek pedig 
kezdettől fogva élesen támadták a kormány védelempolitikai intézkedéseit. (Edmunds 2003, 41-42)

Részben politikai okokból, részben pedig a kormánykoalíció belső vitái következtében Jozo Radoš minisztersége alatt a létszámcsökkentés terén csak korlátozott lépésekre került sor, például 3000, évek óta tartósan betegállományban lévő katonatiszt elbocsátására (Bellamy és Edmunds 2005, 87-88, Bellamy 2002b, 176-177, Bellamy 2003, 198). A tervszerü létszámleépítést már az új miniszter, Željka Antunović indította be az ún. SPECTRA program révén, mely a hadsereg kötelékéből való önkéntes távozást ösztönözte, átképzést illetve pénzügyi támogatást kínálva azoknak, akik így döntenek. A NATO által is támogatott programot később a 2003 őszén hatalomra kerülő HDZ kormányzat is folytatta (Bellamy és Edmunds 2005, 88).

A SPECTRA program eredményei ellentmondásosak voltak: költségei mellett azért is bírálták a programot, mivel esetenként pont a legképzettebb katonákat és tiszteket ösztönözte a távozásra, akik a versenyszférában is megállnák a helyüket (Edmunds 2003, 133-134, Volten 2005, 52). A személyzeti struktúra átalakítása szükségessé tette az előléptetés rendszerének felülvizsgálatát is, mivel a Tudjman-rezsim idején a katonai előléptetésekre kezdetben a harctéri teljesítmény alapján majd később egyre nagyobb mértékben politikai alapon vagy személyes kapcsolatok révén került sor. Ezért a horvát hadsereg tisztikara a 90-es évek végére „fejnehézzé” vált, valamint több esetben olyanok töltöttek be vezető beosztásokat, akik nem rendelkeztek az ehhez szükséges megfelelö képzettséggel. A katonai elöléptetések kérdése szintén a kormány és az elnök közötti hatásköri viták részévé vált, a 2002-ben elfogadott honvédelmi törvény pedig továbbra is tartalmazta a rendkívüli elöléptetés intézményét, amely korábban a politikai alapú előléptetések jogi eszköze volt (Volten 2005, 53-54, Mahecic 2003b, 99-100).

A védelmi minisztérium átalakítása terén az igazgatási apparátus túlméretezettsége mellett a minisztérium és a vezérkar nem kellően tisztázott viszonya, illetve a minisztérium belső müködési zavarai jelentettek problémát. A vezérkar és a minisztérium közötti feladatmegosztás több esetben a 2000-2002 közötti reformok után sem volt pontosan tisztázott, illetve mindkét szervezetnek voltak olyan főosztályai, melyek hatásköre egymást átfedte, a kommunikáció viszont közöttük nem volt kielégítő (Edmunds 2007, 69). Edmunds (2003, 20) és Mahecic $(2003,59)$ szerint ugyanakkor magán a védelmi tárcán belüli, az egyes szervezeti egységek 
közötti információ-áramlás sem volt megfelelő, sőt az egyes főosztályok közötti belső rivalizálásra is akadt példa. Tatjana Cumpek (2003, 123-124) a minisztérium belső müködési problémáit a pártállami rendszerek adminisztratív apparátusára általánosan jellemző, és Horvátországban mind a Tudjman-érában, mind pedig a kétezres évek elején tovább élő, „top-down” szervezeti kultúrára vezeti vissza.

A bürokratikus széttagoltságot némiképp csökkentette, a belső koordinációt pedig javította, hogy 2003-ban a védelmi minisztériumot átszervezték, a főosztályok számára nyolcról négyre csökkentették, ugyanakkor, noha célul tüzték ki a minisztérium és a vezérkar integrálását, ez a vizsgált időszakban nem ment végbe (Edmunds 2003, 70, Watkins 2004, 8, Volten 2005, 47-48).

\subsubsection{A védelmi szféra nemzetközi dimenziója}

A Tudjman-rezsim bukása és az új kormány hivatalba lépése Horvátország nemzetközi kapcsolataiban is korszakváltást jelentett, mivel reálissá vált az euroatlanti integráció célkitűzése (Cziráky 2003, 159, Edmunds 2007, 192-193).

Az euroatlanti integráció feltételrendszere Horvátország esetében a többi csatlakozni kívánó állammal szemben támasztott követelményeket túlmenően tartalmazta a volt Jugoszlávia területén elkövetett háborús bünöket vizsgáló nemzetközi törvényszékkel (ICTY) való együttmüködést is. A NATO vezető illetékesei, például George Robertson akkori főtitkár, már az intézményes kapcsolatfelvétel kezdetétől fogva nyilvánvalóvá tették, hogy a NATO-hoz való közeledés és a Hágával való együttmüködés kérdése szorosan összekapcsolódik. (Simunovic 2015, 187, Szilágyi 2003, 2-3). A nyugati államok ugyanakkor kezdetben komoly jóindulattal és támogatóan viszonyultak az új horvát kormány integrációs törekvéseihez, úgy ítélték meg ugyanis, hogy Horvátország sikeres előrehaladása ezen a téren jó példát jelenthet a többi balkáni állam számára is, így hozzájárulva a térség stabilizációjához (Simunovic 2015, 183, Szilágyi 2003, 3). Ennél fogva a „rezsimváltást” követően a NATO-val való intézményes kapcsolatfelvételre igen gyorsan sor került, és 2000 májusában az országot meghívták a Partnerség a Békéért (PfP) program tagjai közé. Ugyanezen év nyarán állították fel a brüsszeli horvát NATO-képviseletet is (Cziráky 2003, 145, Grdesic 2004, 106-107).

Érdemes megemlíteni, hogy az ország ebben az időszakban több NATO-tagállamtól bilaterális keretek között is részesült védelmi célú támogatásban: az Egyesült 
Államokkal folytatódott a már a Tudjman-érában megkezdődött együttmüködés két, az amerikai kormány által müködtetett program, az International Military Education and Training (IMET) és a Foreign Military Finance (FMF) révén, Németország pedig a béketámogató feladatokra szánt horvát katonai rendőri egység felállításában és kiképzésében nyújtott segítséget 2001 folyamán (Edmunds 2007, 193-194, Mahecic 2003c, 169).

Horvátország 2001 közepétől részt vett a NATO akkori tagjelöltjeit tömörítő Vilniusi Csoport munkájában is, azonban 2002 májusáig a csoport egyetlen olyan tagja volt, melyet még nem hívtak meg a NATO Csatlakozási Akciótervébe (MAP) (Cziráky 2003, 151, Grdesic 2004, 108-109). A kormánykoalíció belső politikai vitái, és a védelmi reformok terén megmutatkozó késlekedés szerepet játszott abban, hogy csak a nemzeti biztonsági és védelmi stratégia, valamint a honvédelmi törvénycsomag 2002. márciusi elfogadását követően, 2002 május 25-én hívták meg Horvátországot a NATO MAP-ba (Szilágyi 2003, 5-6, Cziráky 2003, 151).

Szokatlanul éles kritikát fogalmazott meg a horvát kormánnyal szemben George Robertson NATO-főtitkár egy 2002 júniusi zágrábi konferencián, ahol a fő hiányosságok közül a védelmi minisztérium átalakításának és létszámcsökkentésének elmaradását, illetve a képzett civil köztisztviselők alacsony számát emelte ki.

Dario Cziráky szerint a NATO felől - már ezt megelőzően is - érkező kritikák hozzájárultak ahhoz, hogy a 2002 nyári kormányátalakítás során új miniszter került a védelmi tárca élére, akinek egyik fö célkitüzése a minisztérium átalakítása lett (Cziráky 2003, 144). Hasonlóképp negatívan értékelték Horvátország előrehaladását a NATO szakértői, akik 2003 februárjában az első horvát MAP Éves Nemzeti Programban (ANP) szereplő vállalások megvalósulását vizsgálták. A szakértők a legfontosabb problémák között a szervezeti átalakítások lassúságát, az interoperabilitás megteremtésére irányuló intézkedések elégtelen voltát, valamint a személyi állomány nyelvtudásának hiányosságait jelölték meg (Szilágyi 2003, 13).

A NATO-felkészülés védelmi tárgyú technikai és intézményi jellegü követelményei terén tapasztaltnál is nagyobb nehézséget okozott a horvát kormány számára azon politikai feltételek teljesítése, melyek a daytoni szerződés betartására, illetve a hágai bírósággal való együttmüködésre vonatkoztak.

A Račan vezette kormány katonai szempontból viszonylag gyorsan rendezte az ország viszonyát Bosznia-Hercegovinával: 2000 májusában megállapodást kötöttek a bosnyák-horvát föderáció (FBIH) kormányával, a föderációs hadsereg horvát 
komponensének (Horvát Védelmi Tanács, HVO) finanszírozásáról, és megszakították a HVO és a horvát hadsereg közötti közvetlen kapcsolatokat is. A miniszterelnök arra is ígéretet tett, hogy a boszniai állampolgároknak folyósított horvát katonai nyugdíjak és szociális ellátások rendszerét transzparenssé teszik. Éles belpolitikai viták árán, de a boszniai horvátok szeparatista törekvéseitől is sikerült az új horvát kormánynak elhatárolódnia (NATO Review 2000, Szilágyi 2003, 4-5).

Jóval nagyobb politikai kihívást jelentett a hágai bírósággal való együttmüködés kérdése, mivel ezt illetően nem csak az ellenzéki HDZ illetve a hozzá kötődő veteránszervezetek fogalmaztak meg élesen elutasító álláspontot, hanem építhettek a társadalom többségének ellenérzéseire is (Edmunds 2003, 19, Bellamy és Edmunds 2005, 183). A horvát kormány épp emiatt az „óvatos kooperáció” politikáját követte az ICTY-al való kapcsolatában: 2000 márciusában kiadták a boszniai horvát Mladen Naletilic „Tuta”-t, valamint arról is megállapodás született Hágával, hogy az alacsonyabb rangú vádlottak ügyét horvát bíróságok fogják tárgyalni (Szilágyi 2003, 5, Edmunds 2003, 62). Két magas rangú horvát tábornok ügye azonban igen éles vitákat váltott ki: Ante Gotovina ellen 2001 júliusában emeltek vádat, míg az akkor 83 éves Janko Bobetko - a legmagasabb rangú horvát katona, akit az ICTY vád alá helyezett - kiadatását pedig 2002 őszén kérték Zágrábtól (Lukic és Morel 2002, 37, Edmunds 2003, 62).

Különösen Bobetko ügyében mondható el, hogy a horvát politikai osztály meglehetős egységességgel állt ki a hágai bírósággal szemben, annak ellenére, hogy 2002 szeptemberében és októberében a nemzetközi közösség jelentős nyomást gyakorolt Zágrábra politikája megváltoztatása érdekében. Ugyan 2002 október végén a kormány beleegyezett Bobetko kiadatásába, azonban az idős tábornok egészségi állapota már nem tette lehetővé a bírósági eljárás lefolytatását, melyet az ICTY orvosi szakértői is megerősítettek. A tábornok néhány hónappal később, 2003 áprilisában meghalt, Gotovina letartóztatására azonban egészen 2005-ig nem került sor (Szilágyi 2003, 10, Edmunds 2003, 62-63, Edmunds 2007, 206).

A horvát politikusok taktikázása bizonyos szempontból érthető volt, ugyanis 2002 öszére már nyilvánvalóvá vált, hogy a horvát NATO-csatlakozás, a korábbi, alapvetően irreális reményekkel ellentétben hosszabb időt vesz igénybe, így tehát úgy gondolhatták, az ICTY követelésének teljesítése rövid távon nem jár „,külpolitikai haszonnal”. 
George Robertson NATO-fötitkár ugyanakkor 2002 novemberében külön is nyomatékosította Zágráb felé, hogy a NATO szempontjából a Hágával való együttműködés kérdésében nincs „,vagy”, „talán” és „ha” (Szilágyi 2003, 11-12).

Hasonlóképpen taktikázó-egyensúlyozó magatartás jellemezte a horvát politikát a 2003 tavaszán kibontakozó iraki válsággal kapcsolatban is. A zágrábi döntéshozók tudatában voltak annak, hogy az ország NATO-csatlakozási ambíciói sikerre viteléhez elengedhetetlen az amerikai támogatás, ugyanakkor a kormányzat az EUcsatlakozás szempontjából fontos európai országok álláspontjával sem akart élesen szembehelyezkedni. Tette ezt annak tudatában is, hogy a tervezett iraki katonai beavatkozást a horvát társadalom többsége sem támogatta (Szilágyi 2003, 15-16, Simunovic 2015, 185). A kormány egyfelől 2003 februárjában aláírta a Vilniusi csoport levelét, mely az iraki helyzetet illetően az amerikai álláspontot képviselte, Washington kérése alapján, néhány napos vitát követően pedig a kabinet hozzájárult a légtérhasználat engedélyezéséhez. A hadmüveletek megkezdődése után a kormány azonban sajnálkozását fejezte ki, hogy az ENSZ jóváhagyása nélkül került sor a katonai akcióra. A kormánnyal ellentétben Stjepan Mesić köztársasági elnök kezdettől fogva élesen bírálta az amerikai beavatkozást (Szilágyi 2003, 15-16, Simunovic 2015, 185, Hendrickson és Smith 2006, 303).

Erre az időszakra tehető a horvát nemzetközi missziós szerepvállalás tulajdonképpeni kezdete is, annak ellenére, hogy az első külföldi kontingens kiküldésére még 1999 szeptemberében került sor. 2000 és 2003 eleje között kizárólag az ENSZ égisze alatt vett részt béketámogató műveletekben Horvátország, általában Európán kívüli helyszíneken. Egészen a kétezres évek végéig jellemző volt, hogy történelmipolitikai okok miatt Zágráb közvetlenül nem vett részt a balkáni stabilizációt célzó NATO- és EU-müveletekben (SFOR, KFOR, EUFOR), ezekhez csak logisztikai támogatást nyújtott (Cziráky 2003, 152, Mahecic 2003c, 167-168).

A NATO-hoz való közeledés felgyorsulásával párhuzamosan, 2003 februárjától került sor az első NATO-misszióban történő horvát szerepvállalásra is: az afganisztáni ISAF-misszióban vett részt egy kezdetben nagyjából 50 fős katonai rendőri egység (Ministarstvo obrane RH 2016, 151). 


\subsubsection{A magyarázó tényezök hatásának értékelése}

A történelmi örökség hatása ebben az időszakban leginkább közvetetten értelmezhető. Mint az előző periódusok során említettem, és mint Alex J. Bellamy (2002, 190), Timothy Edmunds (2007, 75-76) és Tatjana Cumpek (2003, 123-124) is rámutatnak, bizonyos szempontból a Tudjman-éra hadserege és védelmi apparátusa tulajdonképpen tovább vitte a jugoszláv periódusra jellemző gyakorlatokat. Ez a jelenség nem csupán a hadsereg átpolitizáltságában volt tetten érhető, hanem olyan kérdésekben is, mint a „titkossági pszichózis” (Edmunds 2007, 69) a védelmi szektorban, vagy a katonaság dominanciája vagy egyenesen monopóliuma a védelmi ügyek terén, és az ezzel foglalkozó képzett civilek alacsony száma (Tatalovic 2010, 18-19). Értékelésem szerint az említett területeken a Tudjman-rezsim fennállásának tíz éve a posztkommunista átmenet egyfajta „elhalasztásaként” értelmezhető, így a 2000 utáni kormányzatnak sok esetben hasonló kihívásokkal kellett szembesülnie, mint az átalakuló országoknak az 1990-es évek elején.

A biztonsági fenyegetés-környezet hatása a 2000 és 2003 közötti periódusban átalakulóban volt. A Milosevics-rendszer bukását követően eltünt a Horvátországot érintő legfontosabb biztonsági fenyegetés, és a balkáni stabilizáció előrehaladásával a regionális környezet is kedvezőbbé vált Horvátország számára. A megváltozott stratégiai környezet megítélése azonban nem volt egyöntetü a társadalom és a döntéshozók körében. Míg az új biztonsági és védelmi stratégiák alapvetően arra a feltételezésre épültek, hogy jelentősen csökkent Horvátország katonai fenyegetettsége (Strategija nacionalne sigurnosti RH 2002, 3-4. pont), a társadalom kisebbsége és a katonai vezetők egy része szkeptikus volt azt illetően, hogy a posztmilosevicsi Szerbia valóban egy demokratikus állammá vált, amely már nem jelent katonai fenyegetést Horvátországra (Bellamy és Edmunds 2005, 78).

Noha ellenkező „elöjellel”, mint az előző két periódusban, a belső politikai folyamatok továbbra is fontos szerepet játszottak a horvátországi civil-katonai kapcsolatok alakulásában. A 2000-ben hatalomra került új kormányzat elkötelezte magát a haderő demokratikus kontrolljának megteremtése mellett, ugyanakkor a kormánykoalíció pártjainak belső vitái sokáig hátráltatták számos, ezen terület szempontjából kulcsfontosságú intézkedés megtételét (például az új honvédelmi törvény elfogadása), mely a biztató kezdet után az ország euroatlanti integrációját is lelassította. 
Megemlítendő még az ún. „tábornokok levele” ügyben hozott államfői intézkedés is, mely tartós hatású precedenst teremtett a haderő civil és demokratikus kontrollja terén.

Mivel a Tudjman-rezsim bukása után drámaian kitágultak az ország nemzetközi kapcsolatai, különösképpen ami az euroatlanti integrációs folyamatokba való bekapcsolódást illeti, megnőtt a nemzetközi szereplők hatása is a védelmi szféra szakpolitikai folyamataira. A 2000 és 2003 közötti időszak azonban a nemzetközi szervezetek által alkalmazott kondicionalitás korlátaira is jó példát kínál. Egyrészt tetten érhető a NATO befolyása, illetőleg hatása bizonyos, a periódusban történt politikai-szakpolitikai kulcsmomentumok esetében. A védelmi törvénycsomag és a két stratégia 2002 márciusi elfogadására részben azért került sor, hogy megteremtsék a lehetőséget Horvátország felvételére a NATO MAP tagjai köze, míg a haderőreform elégtelen előrehaladására vonatkozó NATO-kritikák szerepet játszottak abban, hogy a 2002 nyári kormányalakításkor távozott Jozo Radoš védelmi miniszter (Pietz és Remillard 2006, 36, Tatalovic 2010, 9, Cziráky 2003, 144, Szilágyi 2003, 56). A horvát politikusok az ICTY-al való együttműködés területén tapasztalt taktikázó magatartása ugyanakkor arra is rávilágít, hogy közvetlen „politikai haszon” (ez esetben a rövid távú csatlakozási perspektíva) hiányában a feltételesség politikájának hatékonysága legalábbis korlátozott (Edmunds 2007, 206).

Végezetül, a 2000 és 2003 közötti horvátországi fejlemények arra is példát kínálnak, melyet Bellamy és Edmunds (2005, 80, 84, 89) „pontszerü” (patchy) professzionalizációnak illetve haderő-átalakításnak nevezett: a tényleges reformok egyes kis létszámú egységekre korlátozódtak, annak érdekében, hogy ezen intézkedések a NATO felé konkrét eredményként legyenek felmutathatóak, miközben elmaradtak a nagyobb szabású, gazdaságilag és politikailag is költségesebb strukturális átalakítások (Cziráky 2003, 146-147, Bellamy 2002b, 171172). 


\subsection{Civil-katonai kapcsolatok és euroatlanti integráció a „reform-HDZ” kormányzat alatt (2003-2011)}

\subsection{1. Általános politikai trendek}

A vizsgálatom tárgyát képező utolsó periódus kulcsfontosságúnak tekinthető mind a horvát euroatlanti integrációs célkitüzések, mind pedig ezzel párhuzamosan a demokratikus civil-katonai kapcsolatok, illetve a haderö feletti demokratikus kontroll intézményrendszerének megszilárdítása szempontjából. A nyolcéves időszakot alapvetően szakpolitikai folytonosság jellemezte, a kérdéses időszak mind a három védelmi minisztere ugyanabból a pártból (HDZ) érkezett (lásd pl. Ministarstvo obrane RH 2016, 300-301). Az euroatlanti integrációs erőfeszítések a HDZ kormányzása alatti folytatásának lényeges elözménye, és egyben feltétele is volt a párt vezetésének 2000 és 2003 közötti nagy mértékü kicserélődése. A 2000-ben pártelnökké választott Ivo Sanader ebben a periódusban sikeresen marginalizálta a Tudjman-érában jelentős befolyással rendelkező keményvonalas nacionalista HDZvezetők többségét, különösképpen pedig az úgynevezett „hercegovinai csoport” vagy „hercegovinai lobbi” képviselöit (Longo 2006, 37-39).

Sanader alapvetően azt a célt tüzte ki, hogy vezetése alatt a HDZ „hagyományos” vagy mainstream jobbközép, konzervatív pártként „definiálja újra” magát, mely az ország euroatlanti integrációját helyezi előtérbe. Lényeges ugyanakkor megjegyezni, hogy a pártelit ezen jobbközép fordulatát csak részben követte a párt választóinak „átorientálódása”, valamint a HDZ vezetésében továbbra is több prominens kilencvenes évekbeli nacionalista foglalt helyet (Longo 2006, 38-40).

Sanader hatékonyabban tudta képviselni az euroatlanti integráció programját, és az ehhez szükséges feltételek (például a hágai törvényszékkel való együttmüködést) teljesítését, anélkül, hogy a horvát politika jobboldaláról éles támadásoknak legyen kitéve. Érdemes például megjegyezni, hogy a veteránszervezetek tiltakozásai ebben az időszakban kevésbé voltak intenzívek, mint a Račan-koalíció hivatali ideje alatt (Edmunds 2007, 64, Lukic 2008, 205).

A vizsgálat tárgyát képező nyolc éves időszak első felében a kezdeti néhány hónap „útkeresését” követően előbb 2004 közepe és 2006 között kerültek elfogadásra a haderő átalakítása szempontjából lényeges stratégiai dokumentumok (például a Stratégiai Védelmi Felülvizsgálat), majd pedig 2006 és 2008 között valósultak meg 
azok a szervezeti és jogi változtatások, melyek lehetővé tették, hogy az ország 2008 tavaszán meghívást kapjon a NATO-ba (Simunovic 2015, 193-194). Az időszak második felében, 2008-2009 és 2011 között Horvátország részben eltérő kihívásokkal szembesült: meg kellett teremtenie a védelmi szféra sikeres müködésének feltételeit a NATO-tagság keretei között, a védelmi politikaformálásra jelentős hatást gyakorolt ugyanakkor a gazdasági válság is, mely több területen a korábbi tervek felülvizsgálatára késztette a döntéshozókat (RoC Ministry of Defence 2013, 6, 14, 41-42). Erre az időre tehető, különösen Sanader 2009-es váratlan lemondását, és Jadranka Kosor kormányra kerülését (erről bővebben lásd Economic Intelligence Unit 2009b, 10-12) követően több korrupciós botrány napvilágra kerülése is, melyek általában a 2003 és 2007 közötti HDZ kormányzati ciklusához kapcsolódtak (Knezovic, Mahecic 2012, 76, 96). Ezen korrupciós ügyek egyikének, az ún. teherautó-ügy (afera kamioni) főszereplője Berislav Rončević, a 2003 és 2008 közötti védelmi miniszter volt (Radio Free Europe/Radio Liberty 2009).

Elődjéhez hasonlóan taktikázó-egyensúlyozó magatartás jellemezte Ivo Sanader kormányát a hágai bírósággal (ICTY) való viszonyban is, különösen ami Ante Gotovina ügyét illeti. E magatartást részben az a szándék motiválta, hogy a miniszterelnök nem akarta elidegeníteni a HDZ szavazótáborának nacionalista részét. Noha az ICTY-al való együttmüködés a NATO-csatlakozás feltételei között is szerepelt, mégis az EU-csatlakozási tárgyalások veszélybe kerülése, és a tárgyalások megkezdésének 2005 márciusi elhalasztása késztette arra Sanader kormányát, hogy fokozza fel a tábornok kézre kerítésére irányuló erőfeszítéseket (Edmunds 2007, 204205, Simunovic 2015, 188-189, Pavlakovic 2008, 463-464, 468-469).

Noha a 2000-2003 időszak koalíciós kormányzásával szemben a HDZ két kormányzati ciklusa alatt a kormányzó pártokon belüli konfliktusokról sokkal kevésbé beszélhetünk, a kormány és a köztársasági elnök (Stjepan Mesić) között több alkalommal került sor éles politikai konfliktusra, bár ezen konfliktusok a tágabban értelmezett "biztonsági szektor" intézményei közül inkább a titkosszolgálatok feletti felügyelethez kapcsolódtak, és kevésbé a hadsereg átalakításához (Edmunds 2007, 60-61).

Kezdetben az új kormány álláspontja számos fontos védelmi- és katonapolitikai kérdésben nem világos: így például nem volt tisztázott, a HDZ-kabinet számol-e a sorkatonaság fenntartásával, valamint, hogy hogyan képzeli a horvát légierő jövőjét (Gareljic 2007, 105-106). Az euroatlanti integrációra való felkészülés előmozdítása 
szempontjából Mesić, különösen az új kormány kezdeti időszakában aktív szerepet játszott, és 2004 májusára sikerült több stratégiai kérdésben konszenzust kialakítani a kormány és az államfö között (Volten 2005, 50).

Ezek közé sorolható a kollektív biztonsági felfogás érvényesítése a haderő átalakításában, a sorkatonaság távlati kivezetése, a - csekély harcértékű - tartalékos erők nagyobb részének megszüntetése, illetve egyes katonai beszerzések felülvizsgálata a stratégiai célok tükrében (Ministarstvo obrane RH 2005, 7-8, Volten 2005, 50-52, Baric 2006, 3). Mindezen elvek már érvényesültek az egy évvel később elfogadott Stratégiai védelmi felülvizsgálat (SPO), és a 2006-ban elkészült, a horvát hadseregre vonatkozó hosszú távú fejlesztési terv (DPR) kidolgozásában (Simunovic 2015, 191-192, 193-194). A haderő átalakításával kapcsolatos jelentős kihívások, a terület politikailag érzékeny volta, valamint a katonai-védelmi ügyek iránti fokozódó társadalmi érdektelenség és apátia is közrejátszott abban, hogy a két HDZ kormányzati ciklus alatt is a kormánypárt vezető politikusai között a „népszerütlen” tárcák közé tartozott a honvédelmi (Edmunds 2007, 69, 74-75).

Végezetül röviden szólnom kell a fentebb már említett, ún. teherautó-ügyről, melyben a 2003 és 2008 közötti védelmi miniszter volt érintett.

A horvát védelmi minisztérium 2004 végén hozott döntést katonai teherautók beszerzéséről, melyben azonban a legdrágább ajánlatot tevő beszállítóval kötöttek szerződést. A beszerzéssel kapcsolatban már akkor éles vita robbant ki a köztársasági elnök és a kormány között, mivel Mesić elnök korrupcióval és hivatali visszaéléssel vádolta Berislav Rončevićet, az akkori védelmi minisztert (Edmunds 2007, 69-70). Noha az ügy a 2005-ös elnökválasztási kampányban is szerepelt, formális kivizsgálására egészen 2009-ig nem került sor, egyes vélemények szerint azért, hogy a védelmi miniszter kitölthesse mandátumát (Freedom House 2010).

A kérdés kivizsgálására parlamenti eseti bizottság is alakult, 2009 októberében pedig az ügyészség korrupció miatt vádat emelt Berislav Rončević ellen (Radio Free Europe/Radio Liberty 2009). A korábbi tárcavezetőt 2010 decemberében 4 év börtönbüntetésre ítéltek, azonban az ítéletet a legfelsőbb bíróság később megsemmisítette. Az új eljárás során, 2013-ban felmentették Rončevićet az ellene felhozott vádak alól (Dolenec 2013, 156-157, Economist Intelligence Unit 2011, 11, T-portal.hr 2013). 


\subsubsection{Jogi-intézményi és szervezeti változások}

A Stratégiai Védelmi felülvizsgálat (Strateški pregled obrane, a továbbiakban SPO) előkészítése még 2003-ban kezdődött meg és a 2004 nyarán meghozott, fentebb említett döntéseket beépítették nem csak az SPO szövegébe, hanem Horvátország 2004-2005 éves nemzeti programjába (ANP) is, melyet a NATO MAP programja keretében dolgoztak ki (Baric 2006, 3-4, RoC Ministry of Defence 2005b, 7).

Mind a SPO, mind pedig az azt követő stratégiai és koncepcionális dokumentumok a NATO és egyes NATO tagállamok szakértőinek aktív bevonásával készültek el (Pietz és Remillard 2006, 36, 38). Többek között, kormányközi megállapodás alapján, brit és német tanácsadók is segítették a minisztérium és a vezérkar apparátusát a SPO, valamint a 2006-ban elfogadott hosszú távú hadseregfejlesztési terv kidolgozásában (Tatalovic 2010, 13). Ugyan maga a dokumentum úgy fogalmaz, hogy a SPO a politikai és katonai vezetés közötti együttmüködésben készült el, Edmunds (2007, 148) szerint alapvetően a minisztérium civil apparátusa dolgozta ki.

Noha a katonai vezetés nyilvánosan is támogatta a dokumentumban foglaltakat, egyes megfigyelők szerint a vezérkar egy része később „neheztelt” a minisztériumra és a politikusokra azért, hogy „kihagyták” a stratégiai védelmi felülvizsgálat elkészítéséből (Edmunds 2007, 148).

A 2005-ben kibocsátott SPO alapvetően hasonló kiinduló premisszára épül, mint a 2002-es nemzeti biztonsági stratégia: Horvátország közvetlen biztonsági környezete jelentősen átalakult és lecsökkent a katonai fenyegetés jelentősége. Ezen túlmenően, részben az euroatlanti integrációs folyamat felgyorsulásával, részben pedig gazdasági, illetve a hadviselés átalakulásához kapcsolódó katonai okokból megkérdőjeleződött az eddigi horvát védelmi politika, mely elsődlegesen az önerőből történő országvédelemre épült (RoC Ministry of Defence 2005, 11-14, 15-16).

A hadseregnek és a védelmi igazgatási apparátusnak (minisztérium, vezérkar) mind létszámában, mind pedig felépítésében ezekhez a változásokhoz kell alkalmazkodnia a jövőben (RoC Ministry of Defence 2005, 6-7, 21-22). A fegyveres erök legfontosabb feladatai a jövőben az államterület védelmén túlmenően a nemzetközi béketámogató müveletekben való részvétel, illetve természeti vagy egyéb katasztrófák esetén a civil hatóságoknak nyújtott támogatás lesznek (RoC Ministry of Defence 2005, 17). A szárazföldi haderő területi alapon szerveződő hadtest struktúráját a fentieknek megfelelően fel kell számolni, és a jövőben két, funkcionális 
alapon szervezett dandár lesz a horvát szárazföldi hadsereg legmagasabb szintü egysége. Míg a megszervezendő gépesített-páncélos dandárnak elsősorban területvédelmi feladata lesz, a másik, gépkocsizó gyalogsági / páncélgránátos dandárt alkalmassá kell tenni külföldi bevetéseken való részvételre is ( $\mathrm{RoC}$ Ministry of Defence 2005, 21-22).

A struktúra-átalakítással összhangban tovább kell folytatni mind a hadsereg, mind pedig a minisztérium létszámcsökkentését is, a távlati célzott létszám 16.000 aktív állományú katona, 2.000 civil alkalmazott, illetve 8.000 szerződéses tartalékos (RoC Ministry of Defence 2005, 6). Az SPO összefoglalja a védelmi szférát jellemző főbb problémákat is: a védelmi minisztérium továbbra is túlméretezett, ahol a hatáskörök nincsenek pontosan tisztázva, valamint a minisztérium és a vezérkar közötti viszony, hatáskör- és feladatmegosztás sincs jogilag pontosan szabályozva. A hadsereg személyzeti struktúráját a létszámfeleslegen kívül tovább is jellemzi a háborús időszak öröksége: kedvezőtlen az átlagos életkor, a szervezet alapvetően „fejnehéz”, ezen túlmenően számos tiszt nem rendelkezik a pozíciója és rendfokozata alapján elöírt képzettséggel vagy iskolai végzettséggel sem (RoC Ministry of Defence 2005, 7, 33-34, 38-39). Ennek megfelelően a dokumentum előirányozza a minisztérium létszámcsökkentése mellett annak belső átszervezését, a szervezeti egységek és az egyes tárcák közötti együttmüködés javítását, a vezérkar teljes integrálását a minisztériumba, valamint a kettőjük közötti hatáskör- és feladatelhatárolás pontos szabályozását RoC Ministry of Defence 2005, 7, 39-40). A hadsereg személyi állományát illetően az SPO a személyzeti politika és a képzési rendszer átalakítását, valamint a létszámcsökkentés során az életkori és képzettségi struktúrára vonatkozó fenti célkitüzések előtérbe helyezését tartotta szükségesnek (RoC Ministry of Defence 2005, 33-34). Ezen túlmenően a SPO célul tüzte ki a sorkatonaság öt éven belüli megszüntetését is, azonban, mivel jelentős politikai, társadalmi implikációi vannak a hivatásos haderőre való áttérésnek, ezt csak fokozatosan tartotta lehetségesnek (RoC Ministry of Defence 2005, 16, 31).

A dokumentum a megvalósítandó reformok ütemezése tekintetében két ötéves periódust határozott meg: az első 2005 és 2009 közötti időszakban alakítanák át a minisztériumot és a hadsereget, érnék el a létszámcsökkentési tervben foglalt célkitűzéseket, és kezdődne meg a NATO müveletekre kijelölt egységek képességfejlesztése. Ezt követően, 2010 és 2015 között a védelmi költségvetésben a személyi kiadások aránya 50\%-ra csökkenne, befejeződne a nemzetközi müveletekre 
kijelölt erők interoperabilitásának megteremtése, valamint elérnék a kívánt életkori és képzettségi struktúrát a hadsereg személyi állományában (RoC Ministry of Defence 2005, 37, 42).

A stratégiai védelmi felülvizsgálatban foglaltakra építve fogadta el 2006-ban a horvát parlament a hadsereg hosszú távú 2006 és 2015 közötti fejlesztési tervét (Dugoročni plan razvoja Oružanih snaga Republike Hrvatske, a továbbiakban DPR), mely a kijelölt célok és feladatok ellátásához szükséges, kialakítandó képességeket határozta meg. A terv kifejezetten ambiciózus fejlesztési célkitüzéseket fogalmazott meg, így középtávon a védelmi kiadások GDP-hez viszonyított arányának 2\%-ra emelésével számolt. (RoC Ministry of Defence 2006b, 69-74). Noha már a SPO is kockázati tényezőként jelölte meg, hogy a védelmi kiadások terén kitüzött célok nem valósulnak meg, a hosszú távú fejlesztési terv teljesítése véglegesen a 2008-2009-től kibontakozó gazdasági válság miatt lehetetlenült el. A terv például előirányozta 12 db, korszerü harci repülőgép beszerzését a 2010 utáni időszakban, melyre vonatkozóan 2008 és 2010 között történtek is előkészületek. A jelentősen romló gazdasági helyzet miatt azonban a döntéshozók 2010-ben már azt vizsgálták, miként lenne meghosszabbítható a horvát légierő - a kétezres évek elején modernizált, de így is igencsak elavultnak számító - MiG-21-einek élettartama. (RoC Ministry of Defence 2006b, 29, Ministarstvo obrane RH 2011, 35).

A hadsereg szervezeti átalakítása fokozatosan, több lépésben ment végbe, a négy, területi alapon szervezett hadtest helyett két gárda-dandár került megszervezésre a SPO-ban foglaltaknak megfelelően, melyek 2008 januárjától kezdték meg müködésüket. Hasonlóképpen ment végbe 2007-től kezdődően a haditengerészet átalakítása a parti őrség megszervezésével (Ministarstvo obrane RH 2008, 16, Ministarstvo obrane RH 2009, 16, 19). Ezzel párhuzamosan, 2007-től kezdték meg a vezérkar átszervezését is, mely esetében a cél a szervezeti felépítés egyszerüsítése, a föosztályok számának csökkentése, valamint a feladat- és hatáskörök a minisztérium és a vezérkar közötti világos felosztása volt (Ministarstvo obrane RH 2008, 16, Ministarstvo obrane RH 2009, 19).

A létszámcsökkentési program eredményeképpen 2009-2010 körül sikerült elérni az SPO-ban is kitüzött 16.000 fös állományi létszámot, de az állomány életkori és képzettségi összetételének javítására irányuló törekvések a vizsgált időszak végéig nem jártak sikerrel. Szintén nem sikerült érdemben javítani a horvát hadsereg személyzetének „fejnehéz” jellegén, azaz a tiszti és főtiszti és a legénységi állomány 
egymáshoz viszonyított kedvezőtlen arányán. Ezen túlmenően, a minisztérium civil alkalmazottainak számát illetően még a tervekben kitüzött 2000 fős létszámcsökkentési célt sem sikerült elérni (Ministarstvo obrane RH 2010, 59, RoC Ministry of Defence 2013, 33-34).

Noha a minisztérium által megrendelt, a horvát hadsereg professzionalizációjára vonatkozó szakértői tanulmány (Ministarstvo obrane RH 2003) már a Račankormány utolsó évében elkészült, egészen 2004-2005-ig nem született politikai döntés arról, hogy fent kívánja-e tartani Horvátország a sorkötelezettség intézményét. Mint említettem a stratégiai védelmi felülvizsgálat is csak 5 éves távlatban számolt az önkéntes haderöre való áttéréssel (Gareljic 2007, 105-106, RoC Ministry of Defence 2005, 16, 31). Végül 2007-ben a honvédelmi törvény módosítása teremtette meg azt a lehetőséget, hogy a kormány előterjesztése alapján, az államfő egyetértése mellett a parlament felfüggeszthesse a hadkötelezettséget. Az erre vonatkozó határozatot a horvát parlament 2007.október 5-én fogadta el, hivatalosan 2008. január 1-től függesztették fel a sorkatonai szolgálatot (Hrvatski Sabor 2007).

A NATO-csatlakozás közeledtével megfogalmazódott az alapvető stratégiai dokumentumok (Nemzeti Biztonsági Stratégia, Nemzeti Katonai, illetve Védelmi Stratégia) megújításának igénye is, a vizsgált időszak végéig (2011) azonban az erre irányuló törekvések nem jártak sikerrel (Benedek 2015, 65, Tatalovic 2011, 35-36).

A NATO-csatlakozással és a horvát haderő átalakításával kapcsolatos jogszabályi változtatásokra is több lépésben, 2007 és 2010 között került sor. A törvényi változtatások közül a honvédelmi törvény, a katonai szolgálati jogviszonyról szóló törvény, valamint a horvát hadsereg, rendőrség, és polgári védelem nemzetközi missziós tevékenységét szabályozó törvény módosítása volt a legfontosabb (Ministarstvo obrane RH 2008, 5, 9-10, Ministarstvo obrane RH 2010, 50). A honvédelmi törvény 2007. évi módosítása lehetővé tette a parlament számára az általános hadkötelezettség felfüggesztését békeidőben, törvénybe iktatta a stratégiai védelmi felülvizsgálat jogintézményét, valamint újraszabályozta a horvát hadsereg nemzetközi hadgyakorlatokon való részvételének, illetve ilyen hadgyakorlatok horvátországi megrendezésének feltételeit is (Zakon o izmjenama i dopunama Zakona o obrani 2007, članak 3-4, 6, 11). A törvénymódosítás ezen túlmenően felállította a Védelmi tanácsot, melynek feladata a védelmi tárgyú stratégiai dokumentumok megvitatása, a különböző állami szervek védelemmel kapcsolatos tevékenységének koordinálása, illetve a haderőreform folyamatának figyelemmel 
kísérése. A tanácsot a miniszterelnök és a köztársasági elnök mellett a parlament elnöke, a belügy-, külügy-, védelmi, és pénzügyminiszter, a vezérkari főnök, a polgári védelem országos parancsnoka, valamint a köztársasági elnök kabinetjének védelmi és katonai kérdésekkel foglalkozó magas beosztású tisztségviselői alkotják (Zakon o izmjenama i dopunama Zakona o obrani 2007, članak 7).

Végezetül, a horvát alkotmány a fegyveres erőkről szóló 7. cikkelyét 2010-ben módosították azzal a céllal, hogy kodifikálják a NATO-csatlakozás által szükségessé tett változtatásokat. A cikkely új szövege tartalmazza a kollektív védelemre vonatkozó jogszabályi passzusokat, valamint a horvát haderő külföldön történő alkalmazását, illetve külföldi (benne szövetséges) haderők horvátországi állomásoztatását a parlament és a köztársasági elnök hozzájárulásához köti. A köztársasági elnök hozzájárulásának hiányában a parlament kétharmados többsége szükséges. A parlament jóváhagyásra vonatkozó követelmény alól csak a hadgyakorlatok, illetve a humanitárius segítségnyújtás esete képez kivételt (Constitution of the Republic of Croatia 2014, Art. 7.).

Korábban már tettem említést arról, hogy a fegyveres erők parlamenti felügyelete az igen széles illetékességi körü, belügyi és nemzetbiztonsági bizottsághoz tartozott. Noha tervezték e bizottságon belül egy védelmi albizottság felállítását, ez azonban a valóságban csak „papíron” jött létre (Edmunds 2007, 81). Mivel az euroatlanti integráció felgyorsulásával egyre több feladat hárult a parlamenti szakbizottságra is, a 2007-ben megválasztott parlamentben megalakították az önálló védelmi bizottságot, melynek, intézményi innovációként, szavazati jog nélküli külső szakértő tagjai is voltak (Tabak 2011, 87-88). Az önálló szakbizottság létrejötte ugyan javította a fegyveres erők parlamenti kontrolljának minőségét, a külső szakértői tagok pedig pozitívan járultak hozzá a bizottság munkájához, a védelmi bizottság üléseinek többségén a jogalkotással kapcsolatos kormányzati előterjesztések megvitatása, illetve a horvát hadsereg missziós szerepvállalása játszotta a legfontosabb szerepet. A jelentősebb katonai beszerzések, a védelmi költségvetés, illetve a fegyveres erőkkel kapcsolatos aktuális kérdések, ügyek, a bizottság napirendjén korlátozottan szerepeltek, utóbbiakat általában akkor a bizottság tagjai akkor tárgyalták, amikor a média révén már a közérdeklődés középpontjába kerültek (Tabak 2011, 95-96). Ezzel együtt a parlament a végrehajtó hatalommal szemben továbbra is a „gyengébb” vagy „kisebbik partner” (junior partner) szerepét játszotta a fegyverek erők demokratikus ellenőrzésében (Edmunds 2007, 71). 


\subsubsection{A védelmi szektor nemzetközi dimenziója}

Ebben az időszakban a védelmi szféra nemzetközi kapcsolatainak és tevékenységének alapvetően két fö eleme volt: részben a NATO-csatlakozási folyamat felgyorsulása és sikeres befejezése 2008-2009-ben, részben pedig a regionális együttmüködés intenzívebbé válása a védelmi, katonai kérdések területén is. Ez a Račan-kormányzat alatt megkezdődött és a Sanader-érában folytatódó tendencia jelentős különbséget jelent a tudjmani korszak gyakorlatához képest, amikor a kormányzat élesen elzárkózott a „balkáni” államokkal való bármiféle intézményes kapcsolatteremtéstől (lásd pl. Szilágyi 2003, 15).

Kifejezetten a NATO-csatlakozásra való felkészülést szolgálta a 2003-ban amerikai támogatással Horvátország, Albánia és Macedónia által megalakított Adriai Alapokmány vagy Adriai Karta (Adriatic Charter) kezdeményezés (Grdesic 2004, 115-116, Vukadinovic 2008, 6-7). Az Adriai Alapokmány keretein belül folytatott együttmüködés eredményeként 2005-től közös horvát-macedón-albán katonaorvoscsoport teljesített szolgálatot Afganisztánban, az NATO által vezetett ISAF misszióban (RoC Ministry of Defence 2006, 14, RoC Ministry of Defence 2007, 7). 2008-tól a kezdeményezéshez Bosznia-Hercegovina és Montenegró is csatlakozott (U.S. Department of State 2008). Csatlakozását követően Horvátország aktívan támogatta a többi nyugat-balkáni ország NATO-csatlakozását is (Jakesevic et al 2017). A NATO lisszaboni csúcsértekezletén, ahol Horvátország először vett részt teljes jogú tagként, a horvát diplomácia egyik célja volt, hogy a találkozó zárónyilatkozata külön hangsúlyozza a nyugat-balkáni országok NATO-csatlakozási perspektíváját (Ministarstvo obrane RH 2011, 11).

A NATO-csatlakozás folyamata 2004-2005-ben gyorsult fel és a 2006-os rigai csúcsértekezlet úgy döntött, két év múlva meghívják a szervezetbe azon tagjelölt államokat, melyek addig teljesítik a szükséges feltételeket. A sikeres felkészülést követően a 2008 évi bukaresti csúcsértekezleten hívták meg Horvátországot a szervezetbe, majd a csatlakozási tárgyalások lezárultát követően 2008. július 9-én írták alá az erről szóló brüsszeli megállapodást. A csatlakozási szerződés tagállami ratifikációját követően Horvátország 2009. április 1-én vált a NATO teljes jogú tagjává (RoC Ministry of Defence 2007, 4, RoC Ministry of Defence 2009, 5, Ministarstvo obrane RH 2010, 9). A csatlakozási tárgyalások lezárulta után elfogadott reformokra vonatkozó menetrend (Timetable for Reform), meghatározta a 
feladatokat, melyek annak érdekében szükségesek, hogy a horvát fegyveres erők és a védelmi apparátus eredményesen tudjon müködni a NATO tagjaként. Szintén a teljes jogú tagságra való felkészülést szolgálta, hogy 2008-ben a horvát védelmi minisztérium első alkalommal küldte meg válaszait a NATO védelmi tervezési kérdőívére (Defence Planning Questionnaire). Az ekkor elfogadott fejlesztési célkitüzések már a NATO Haderőfejlesztési Célok (NATO Force Goals) részét képezték, és alapvetően arra irányultak, hogy a szárazföldi haderők 40\%-a legyen alkalmas külföldi missziós szerepvállalásra, valamint, hogy a horvát hadsereg képes legyen egy időben a szárazföldi erői 8\%-át külföldön állomásoztatni (Ministarstvo obrane RH 2009, 5-6, 35-36). A horvát hadsereg NATO struktúrákba való integrálása a csatlakozást követően fokozatosan történt, ennek sikeres befejezéséről szóló nyilatkozatot a NATO és Horvátország képviselői 2012. október 25-én írták alá (Ministarstvo obrane RH 2011, 11, RoC Ministry of Defence 2016, 123).

A következőkben három kérdést fogok bővebben tárgyalni, melyek közvetlenül vagy közvetetten kapcsolódtak a horvát NATO-csatlakozási folyamathoz: a tagság társadalmi támogatottságának kérdése, az ICTY-al való együttmüködés, valamint a horvát hadsereg külföldi missziós szerepvállalása.

Mint korábban említettem, a Sanader vezette horvát kormányzat is egyfajta „húzd meg, ereszd meg” politikát folytatott a hágai bírósággal való együttmüködés terén. Sanader egyfelöl 2004 elején meggyőzte a Gotovinán kívül az 1995-ös „Vihar” hadművelettel kapcsolatban vád alá helyezett két horvát katonai és rendőri vezetőt, Ivan Čermakot és Mladen Markač -t, hogy önként adják fel magukat Hágában (Pavlakovic 2008, 461). Másfelől, részben politikai, részben pedig gyakorlati okokból a kormány eleinte csak korlátozott erőfeszítéseket tett a körözött tábornok kézre kerítésére. A politikai akarat hiányán túlmenően arra is voltak példák, hogy a rendőrség és a titkosszolgálat egyes tagjai esetenként szabotálták a Gotovina elfogására irányuló erőfeszítéseket. Ugyanakkor az is igaz, hogy egészen 2005 elejéig a még 2000-ben a „tábornokok levele” incidens miatt nyugállományba helyezett Gotovina katonai nyugdíját továbbra is folyósították, illetve vagyonának zár alá vételére sem került sor (Edmunds 2007, 143-144, Pavlakovic 2008, 462-463). A Sanader-kormány csak azt követően fokozta fel erőfeszítéseit Gotovina kézre kerítésére, hogy az Európai Unió 2005 márciusában elhalasztotta Horvátországgal a csatlakozási tárgyalások megkezdését az ICTY-al történő együttmüködés hiányosságai miatt. Carla del Ponte, az ICTY vezető ügyésze 2005 szeptemberének 
végén már kielégítőnek minősítette a horvát együttmüködést Hágával. Gotovinát végül 2005 decemberében, a Kanári-szigeteken vették örizetbe (Edmunds 2007, 205206).

Érdemes megemlíteni, hogy mind Gotovinát, mind pedig a perében érintett két másik vádlottat, Čermakot és Markač-t 2011-ben és 2012-ben jogerősen felmentette a hágai törvényszék (Simunovic 2015, 188).

A NATO-tagság társadalmi támogatottsága egészen 2003-2004-ig igen magas volt, a kilencvenes években például esetenként a 90\%-ot is megközelítette (Vukadinovic 2008, 7). A 2006-os lisszaboni NATO csúcsértekezlet záróokmányában mégis arról tettek említést Horvátországot illetően, hogy a szövetségbe való meghívásáig növelnie kell a NATO-csatlakozás társadalmi támogatottságát. E támogatottság 2006 őszén érte el mélypontját, novemberben például a Puls közvéleménykutató cég szerint a megkérdezettek kevesebb mint 30\%-a értett egyet Horvátország NATO-hoz való csatlakozásával (Gareljic 2006, 115, RoC Ministry of Defence 2007, 4). Több okkal is magyarázható, hogy megcsappant a NATO-tagság népszerüsége a kétezres évek közepére (Vukadinovic 2008, 7).

Az Egyesült Államok 2003-as iraki beavatkozása, Európa nagyobb részéhez hasonlóan, Horvátországban is népszerütlen volt, és sokan a NATO-t az Egyesült Államokhoz és a Bush-adminisztráció politikájához társították (Hendrickson, Smith 2006, 302-303). Szerepet játszott ugyanakkor, hogy a NATO-csatlakozás egyik feltétele a hágai ICTY-al való együttmüködés volt, mely kérdés, mint említettem, jelentős vitákat váltott ki a horvát politikában és társadalomban (Tatalovic 2007, 115116, Dujmovic 2008, 74-75, Vukadinovic 2008, 8). A NATO-csatlakozásról folyó közéleti vitában megjelenő ellenérvek ezen túlmenően részben hasonlóak voltak, mint Szlovénia esetében: NATO-bázisokat fognak az ország területén létesíteni, a kormány beleegyezése nélkül fognak horvát katonákat külföldi missziókra küldeni, a katonai bázisok létesítése és a hadgyakorlatok megtartása súlyosan károsítani fogja a környezetet az alapvetően turizmusból élö tengerparti régiókban, az ország terrorfenyegetettsége fokozódni fog, túlzottan drága a NATO-tagság, és végezetül, elegendő lenne Horvátországnak csak az Európai Unióhoz csatlakoznia (Vukadinovic 2008, 8-9, Tatalovic 2007, 115-116). Mint látható, ezen érvek némelyike teljesen valótlan volt (pl. missziós részvétel a kormány engedélye nélkül), vagy pedig féligazságokat tartalmazott.

A NATO-csatlakozással kapcsolatos aktív tájékoztató és népszerüsítő kampányt a 
horvát kormányzat 2007-ben indította el, és ez is közrejátszhatott abban, hogy növekedésnek indult a tagság támogatottsága. A csatlakozáspártiak számának növekedését azonban regionális napi politikai események is befolyásolták, mind például a Szerb Radikális Párt jelöltjeinek jó szereplése a 2007-es és 2008-as szerbiai választásokon, vagy Koszovó függetlenségének kikiáltása 2008 elején, amelynek következtében zavargások törtek ki Belgrádban és a horvát nagykövetség épületét is megrongálták (Vukadinovic 2008, 14-17, Dujmovic 2008, 76-77, Tatalovic 2007, 118-119, Simunovic 2015, 195-197, 203).

A 2007-es választást megelőzően rövid időre politikai vita tárgyává vált a NATO-ba való belépésről rendezendő népszavazás kérdése. A kormányon lévő HDZ ellenezte, míg az ellenzéki Szociáldemokrata Párt (SDP), illetve a Horvát Parasztpárt, valamint vele a választáson közösen induló Horvát Szociálliberális Párt (HSS-HSLS) támogatta a referendum megtartását. A választást követően újra a HDZ alakított kormányt, egyik koalíciós partnere, a HSS-HSLS viszont a koalíciós szerződésben lemondott a népszavazásra vonatkozó követelésről. Különbözö NATO-ellenes civil szervezetek ugyanakkor nem tudták összegyüjteni a referendum megtartásához szükséges elegendő számú aláírást (Economist Intelligence Unit 2008, 3, Congressional Research Service 2009, 8). A NATO-csatlakozásról így Horvátországban nem tartottak népszavazást, a szervezetbe való meghívásról döntő 2008 tavaszi bukaresti csúcsértekezletet követően az egyes közvéleménykutatások 57 és 67 százalék közöttire tették a belépést támogatók arányát (Dujmovic 2008, 77).

A tulajdonképpeni csatlakozás időpontjában, 2009 áprilisában pedig 62\% körüli volt ez az érték (Tatalovic 2010, 17).

A horvát hadsereg külföldi missziós szerepvállalása, mint láttuk, a kétezres évek elején részben forráshiány, részben a megfelelően kiképzett és felszerelt egységek hiánya miatt leginkább főleg szimbolikus jellegü volt. A 2003-at követő időszakban ez lassan kezdett csak megváltozni, és a döntéshozók tudatában voltak annak, hogy gazdasági korlátok miatt később sem lesz reális komolyabb katonai erő ilyen célra történő felajánlása, ezért elsősorban specializált, niche képességek kialakítására törekedtek (Tatalovic 2010, 13).

A NATO keretében történő horvát missziós részvétel fő „színtere” az afganisztáni ISAF misszió volt. Mint említettem, az ISAF-ba kiküldött horvát kontingens kezdetben 50 föt tett ki, mely létszám fokozatosan nőtt: 2006-tól kb. 150, 2008-tól 275, 2010-ben több mint 300, majd 2011 végén pedig 340 horvát katona teljesített 
szolgálatot Afganisztánban (RoC Ministry of Defence 2006, 14, Ministarstvo obrane RH 2009, 6, Ministarstvo obrane RH 2011, 97, Ministarstvo obrane RH 2012, 18). Horvátország 2004-től a Tartományi Újjáépítési Csoportok (PRT) munkájába is bekapcsolódott, 2006-tól pedig jelentősen bővítették a horvát kontingens létszámát, egy, az Afgán Nemzeti Hadsereg (ANA) kiképzésében közremüködő egységgel (Operational Mentoring and Liaison Team, OMLT). A horvát ISAF-kontingens fö tevékenységi köre továbbra is a képzés-kiképzés maradt, 2011-től pedig Horvátország lett az afgán katonai rendőrök kiképzését végző program ún. vezető nemzete (lead nation) (RoC Ministry of Defence 2006, 14, Ministarstvo obrane RH 2016, 151-152).

Horvát harcoló alakulatok nem szolgáltak Afganisztánban (Polak et al 2009, 513).

Noha a Balkánon müködő nemzetközi béketámogató misszióknak (IFOR, SFOR, KFOR, EUFOR Althea) Horvátország kezdettől fogva biztosított logisztikai támogatást, Boszniában egyáltalán nem vett részt ezek tevékenységében (nyilvánvaló okokból), a koszovói KFOR misszióba pedig katonai alakulattal csak 2009-ben kapcsolódott be, amikor 2 Mi-171-es szállító helikopter és a hozzá tartozó személyzet került kiküldésre (Watkins 2004, 7, Ministarstvo obrane RH 2009, 37, Ministarstvo obrane RH 2010, 18, Ministarstvo obrane RH 2012, 20-21).

Horvátország már taggá válását megelőzően több évvel bekapcsolódott az Európai Unió egyes katonai kezdeményezéseibe, illetve misszióiba. A 2008-ban Csádba és a Közép-Afrikai Köztársaságba küldött EUFOR Chad/CAR EU-misszióban 15 horvát katona is részt vett, 2011-ben pedig az ország bekapcsolódott az EU Harccsoportok (EU Battle Groups) tevékenységébe is, a svéd vezetés alatt álló skandináv harccsoport részeként (Ministarstvo obrane RH 2009, 6, Ministarstvo obrane RH 2012, 3). Mint korábban említettem, a vonatkozó jogszabályok, és a 2010-ben módosított alkotmány is a horvát katonaság külföldi missziókon való részvételének jóváhagyását alapvetően a parlament hatáskörébe utalta. A törvényhozás általában évente, vagy szükség esetén évente többször is döntött például az ISAF misszióba kiküldött horvát kontingens létszámáról, 2009 októberétől pedig a minisztérium három havonta külön is tájékoztatja a parlamenti védelmi bizottságot a külföldi missziós szerepvállalás aktuális kérdéseiről (Ministarstvo obrane RH 2010, 16-17, Ministarstvo obrane RH 2011, 13-14). Az ezzel kapcsolatos kormányzati döntéshozatal meggyorsítása érdekében egyes esetekben a Sabor egyszerre több évre is meghatározta a NATO-müveletekben részt vevő horvát kontingens engedélyezett 
legnagyobb létszámát, így történt például 2011 májusában, amikor a 2011-2013 időszakra vonatkozó létszámról döntöttek a képviselők (Ministarstvo obrane RH 2012, 18). Igor Tabak adatai szerint 2008 és 2010 között a parlamenti védelmi bizottság üléseinek 25\%-a missziós szerepvállalással volt kapcsolatos, azonban a vonatkozó kormányzati előterjesztéseket általában komolyabb vita nélkül jóváhagyták a bizottság tagjai, pusztán az engedélyezett létszám kapcsán került csak sor esetenként érdemi vitára (Tabak 2011, 95).

\subsubsection{A magyarázó tényezők hatásának értékelése}

A megvizsgált négy időszak közül 2003 és 2011 között volt a leggyengébb a történelmi örökség hatása az általam vizsgált területre. Több, a haderő demokratikus kontrollja terén ekkor továbbra is meglévő probléma, mint például a katonai-védelmi kérdésekkel foglalkozó képzett civilek alacsony száma (Tatalovic 2010, 18-19), vagy a minősített információk körének túlzottan széles volta (Tabak 2011, 93-94) eredete azonban a jugoszláv, vagy ezeken a területeken a jugoszlávtól nem sokban különböző tudjmani időszakhoz kötődik. Ezen túlmenően Simunovic $(2015,196)$ pedig arról tesz említést, hogy a NATO-val és részben az Egyesült Államokkal szembeni ekkori társadalmi attitüdökben szerepet játszhatott a jugoszláv éra elnemkötelezett külpolitikai „tradíciója” is.

A nemzetközi fenyegetés-környezet megítélésem szerint a teljes 1991-2011 időszak alatt szintén ebben periódusban játszotta a legkisebb szerepet a vizsgált területen. A kétezres évek során a hagyományos fenyegetések, különösképpen a környezö államok által jelentett katonai fenyegetés háttérbe szorult, és az ekkor kibocsátott különböző kormányzati dokumentumok is már elsődlegesen az olyan új típusú biztonsági kihívásokat emelték ki, mint például a terrorizmus, a tömegpusztító fegyverek proliferációja, vagy a tömeges migrációs folyamatok (Tatalovic 2010, 18 19, és lásd pl. RoC Ministry of Defence 2005, 11-14, Ministarstvo obrane RH 2009, 5, Ministarstvo obrane RH 2010, 11-12). Érdemes ugyanakkor megemlíteni, hogy a NATO-csatlakozás társadalmi támogatottságának mértékét 2007-ben és 2008-ban esetenként bizonyos szerbiai események is befolyásolták (Tatalovic 2007, 118-119), ez tehát arra utal, hogy csekély mértékben, de még jelen volt a társadalomban a korábbi időszakokra jellemző fenyegetés-percepció is.

A belső politikai környezet hatása 2003 és 2011 között az elöbbi időszaknál kevésbé 
volt jelentős. Ennek magyarázata főként abban keresendő, hogy az néhány hónap „útkeresését” követően sikerült egyfajta minimális konszenzust kialakítani az euroatlanti integráció, valamint a fegyveres erők esetében az ehhez szükséges reformok alapvető kereteiről (Simunovic 2015, 182-183). Ezáltal tehát a korábbi Račan-éra éles belső koalíciós viszályai, valamint kormány-ellenzék szembenállása nem hátráltatta a szükséges reformokat (Edmunds 2007, 60-61). Ezen túlmenően, Sanader mint a HDZ politikusa nagyobb sikerrel tudta elfogadtatni a politikailag kényes intézkedéseket (például létszámcsökkentés vagy az ICTY-al való együttmüködés) a hadsereg tisztikarával, illetve az ezen intézkedéseket korábban élesen ellenző háborús veteránok csoportjával is (Lukic 2008, 205).

A pártok között alapvető kérdésekben meglévő konszenzus azonban nem jelenti azt, hogy a 2003 utáni periódusban ne lettek volna időről időre éles viták az államfó és a kormány között biztonsági-védelmi kérdésekben, valamint nem övezte egyöntetü társadalmi-politikai egyetértés a Hágával való együttmüködés kérdését sem.

A 2003 és 2011 közötti időszakban egyértelmüen a nemzetközi szereplök és szervezetek hatása volt meghatározó jellegü Horvátországban az általam vizsgált területen. Ez a hatás alapvetően három különböző formában jelentkezett.

Egyfelől bizonyos konkrét politikai döntések meghozatalát vagy stratégiai dokumentumok elfogadását a NATO-csatlakozási folyamat felgyorsulása motiválta. Ebben a fejezetben már tettem említést arról, hogy a haderő további fejlesztési irányaival kapcsolatos legfontosabb döntésekre - például a kollektív védelmi felfogás érvényre juttatása - 2004-2005 körül került sor, amikor intenzívebbé vált Horvátország bekapcsolódása a NATO MAP (Membership Action Plan, Tagsági Akcióterv) programjába (Edmunds 2007, 200-201). Tatalovic (2010, 13) arról tesz említést, hogy a Nemzeti Biztonsági Stratégia megújítására irányuló erőfeszítések is leginkább a NATO-csatlakozás közeledtével váltak aktuálissá. Másodszor, a nemzetközi szervezetek szerepe „tetten érhető” a fontosabb stratégiai dokumentumok elkészítésében, vagy a NATO-felkészülés adminisztratív folyamatában is. A Stratégiai Védelmi Felülvizsgálat, valamint a hosszú távú hadseregfejlesztési terv elkészítésében brit és német tanácsadók is segítették a Védelmi Minisztérium és a vezérkar tisztviselőit. Pjer Šimunović, az ebben az időszakban a NATO csatlakozási folyamat nemzeti koordinátoraként tevékenykedő vezető horvát diplomata külön is kiemeli Frank Boland, a NATO védelmi tervezésért felelős igazgatója és csapata által a horvát minisztériumi apparátusnak folyamatosan nyújtott segítséget (Simunovic 
2015, 194). Ilyen értelemben ezen periódusban Horvátország esetében is találkozhatunk a horvát és NATO szereplők részvételével létrejövő „transznacionális koalícióval" (Epstein 2005, 69-70), mely hozzájárult a csatlakozáshoz szükséges reformok sikeres végrehajtásához

Végezetül, a NATO-csatlakozási törekvések megjelentek a horvát haderő missziós szerepvállalására vonatkozó döntésekben, és egyes fontosabb katonai beszerzések terén is. A időszak nagyobb részében (különösen 2004-2005-től) az afganisztáni ISAF misszió volt a horvát katonaság külföldi szerepvállalásának főbb „színtere”, amely megítélésem szerint elsősorban a NATO-csatlakozási ambíciókkal magyarázható. A már említett Šimunović szerint a horvát hadsereg afganisztáni missziós szerepvállalása az ország egyik „katonai belépőjegye” volt az atlanti szövetségbe (Simunovic 2015, 194). Egy 2006-os kormányzati előterjesztés indoklása pedig egyenesen így fogalmaz: „Az EU- és NATO-csatlakozásra vonatkozó stratégiai céljaink elérése érdekében szükséges az afganisztáni béketámogató müveletben részt vevő kontingensünk létszámának növelése" (Gareljic 2006, 119).

Külön is érdemes megemlíteni a horvát szerepvállalást az Európai Unió által vezetett missziókban, és katonai kezdeményezésekben abban az időszakban amikor az ország még nem volt uniós tagállam. Az EUFOR Chad/CAR misszióba 2008-ban kiküldött ugyan jelképes méretü- horvát katonai kontingens, illetve Horvátország részvétele az EU Harccsoportok (EU Battle Groups) tevékenységében 2011-től értékelésem szerint az ország európai integráció melletti elkötelezettségének demonstrálását is szolgálta.

A NATO-integrációs célkitüzések a fontosabb katonai beszerzésekre is hatást gyakoroltak: a horvát hadsereg képességfejlesztési lépései között kiemelt szerepet kapott a Patria AMV harcijárművek beszerzése, melyeket a hadsereg a különféle külföldi missziós müveletek során (mint például az ISAF) is fel kívánt használni (RoC Ministry of Defence 2005, 34-35, RoC Ministry of Defence 2012, 22). Noha később a költségek csökkentése érdekében újratárgyalták a Patria-szerződést és módosították a megrendelt jármüvek müszaki tartalmát, a beszerzés törlésére, vagy a beszerzett jármüvek számának csökkentésére (mint Szlovénia esetében) még akkor sem került sor, amikor a gazdasági válság miatt jelentősen „megvágták” a katonai költségvetést (Ministarstvo obrane RH 2010, 75, Ministarstvo obrane RH 2011, 52). 


\subsection{A horvát eset főbb sajátosságai}

Horvátországban a köztársasági kommunista szövetségben a reformszárny hatalomra kerülésére csak az 1980-as évek végén került sor.

A HDZ által képviselt horvát nacionalista mozgalom részben Milosevics nagyszerb nacionalista programjára, részben a korábbi horvát kommunista vezetés által a nyolcvanas évek közepéig-második feléig képviselt keményvonalas irányvonalra válaszul, arra adott reakcióként jött létre (Cohen 1997, 71-72, Pickering és Baskin 2008, 524-525, Tanner 2001, 204-206, 221-223, Meier 1999, 128-131). A HDZ pártban kezdettől fogva jelentős szerepet játszottak a horvát nacionalista diaszpóra egyes képviselői is (Hockenos 2003, 27-30, 31-32).

Az első szabad választás után hatalomra kerülő HDZ ,államépítő” és függetlenségi programot képviselt, azonban ennek megvalósítását már az országon belüli (szerbek és horvátok közötti) etnikai feszültségek kiéleződése, illetve a Belgrád és Zágráb közötti konfliktus elmélyülése közepette kezdte meg. A krajinai szerbek felkelése következtében a horvát kormány már 1990 augusztusa és 1991 májusa között az államterület több része felett elveszítette az ellenörzést (Cohen 1997, 77-80, Juhász 1999, 226-229).

Mivel a szövetségi hatóságok, Szlovéniával ellentétben, a horvát köztársasági területvédelmet teljesen lefegyverezték, a horvát védelmi erők kialakítására kezdetben a rendőrség bázisán került sor, az 1991 tavaszán felállított Nemzeti Gárda (ZNG) a megelőző hónapokban megalakított és kiképzett különleges rendőri egységekre épült. Az önálló haderő kialakítására irányuló törekvéseket befolyásolta, hogy a horvát államfö, Franjo Tudjman, 1991 nyaráig a háború elkerülésére törekedett. Ez az irányvonal csak 1991 augusztus-szeptemberében részben az eszkalálódó fegyveres összecsapások hatására változott meg, melyben a szövetségi haderő, a JNH már nyíltan a horvátországi szerb szakadárok oldalán lépett fel (Central Intelligence Agency 2002, 91, Central Intelligence Agency 2003, 45-46, Tanner 2001, 234-235, Vego 1993, 203-204, Juhász 1999, 232-237).

A Horvát Hadsereg (HV) 1991 szeptemberében a Nemzeti Gárda és különböző, civil önkéntesekből álló védelmi egységek bázisán alakult meg, fegyverzetét pedig nagyobb részt az 1991 őszén a JNH horvátországi laktanyáinak blokádja után az onnan zsákmányolt katonai eszközök alkották (Juhász 1999, 239-240, Lukic 2009, 192-193). A megalakuló horvát haderő személyzeti állománya rendkívül heterogén 
volt: a korábbi JNH és a Területvédelem (TO) tisztjei, a háborús konfliktusban részt vevő civil önkéntesek, valamint a horvát diaszpóra külföldi katonai (például francia idegenlégiós) tapasztalattal rendelkező tagjai is megtalálhatóak voltak soraiban.

A háborús helyzet miatt a JNH-ból érkező, szaktudással és képzettséggel rendelkező tisztek a horvát hadseregben a szlovénnél jelentősebb szerepet játszottak, annak ellenére is, hogy a kormányzat igyekezett a korábbi JNH-tiszteket és tábornokokat a tisztikar politikailag megbízhatóbbnak tartott tagjai javára háttérbe szorítani (Edmunds 2007, 124-125, Lukic 2008, 193-196).

A háborús helyzet és a Tudjman-kormányzat kezdettől meglévő autoriter tendenciái is hozzájárultak ahhoz, hogy a kilencvenes években a civil kontroll nem demokratikus, hanem autoriter formája épült ki Horvátországban. (Horowitz 2005, 162-163, Edmunds 2007, 54, Bellamy 2002, 177). A védelmi-katonai kérdéseket illetően a döntéseket általában az államfö vagy a bizalmi emberének számító védelmi miniszter, Gojko Šušak (1991-1998) hozta meg, míg a parlament és esetenként a kormány is háttérbe szorult (Ramet 2010, 259-260, Edmunds 2003, 14-15, Edmunds 2007, 54-55). Általánosan elterjedt volt a tiszti és fötiszti kar tagjainak a kormányzó pártban meglévő tagsága, esetenként a párt vezető testületeiben való részvétele, miközben lojalitásukat anyagi elönyök, privilégiumok nyújtásával is igyekeztek biztosítani (Bellamy 2002, 176-177, Edmunds 2007, 56-57).

A hadsereg ugyanakkor a politikai elit és a Tudjman-rezsim kliense volt, nem vált autonóm politikai szereplővé, így a háborús helyzet ellenére sem volt jellemző, hogy a katonák külpolitikai vagy biztonság- és védelempolitikai kérdésekben befolyással rendelkeztek volna (Zunec 1996, 226-227).

A kormányzat a hadsereg magas társadalmi elfogadottságát saját legitimitásának erősítésére, illetve nacionalista politikai programjának alátámasztására is felhasználta, de a fegyveres konfliktus politikai „instrumentalizálására”, eszközként való használatára is több példát találhatunk. A horvát parlament alsó- és felsőházának választásai során a hadsereg magas rangú képviselői gyakran szerepeltek a kormánypárt képviselöjelöltjei között, bizonyos katonai mủveletek sikeréből pedig a kormány igyekezett politikai tőkét kovácsolni. A horvátországi háború, különösen pedig a horvát hadsereg a krajinai szerb szakadárok feletti végső győzelmével végződő 1995 nyári Villám és Vihar hadművelete, a horvát állam, illetve a Tudjmanrezsim egyfajta „eredetmítoszává” vált (Vankovska 2002, 58-59, Mihaljevic 2012, 135-136, Bellamy 2003, 193-194, Bellamy és Edmunds 2005, 72-73). 
Annak ellenére, hogy 1995-ben befejeződött a horvátországi konfliktus, a háborús időszakot jellemző autoriter hatalomgyakorlási módszerek és technikák alkalmazása tovább folytatódott. Nem változott érdemben a védelmi szektor és a védelmi minisztérium irányítási módja sem: továbbra is jellemző volt a hatalomkoncentráció, az átláthatatlanság, gyakori és indokolatlan titkosítás, a pazarló gazdálkodás, illetve a korrupció és különböző pénzügyi visszaélések elterjedtsége (Dolenec 2013, 142-143, Bellamy 2002, 185-186, 188, Bellamy 2003, 188-189).

A Horvát Hadsereg (1996-tól Horvát Fegyveres Erők, OSRH) belső viszonyait Timothy Edmunds $(2007,127)$ mefogalmazásában a „befelé forduló stagnálás” (inward looking stagnation) jellemezte: szerkezete és főbb feladatai alapvetően 2000-ig keveset változtak 1995-höz képest.

A kilencvenes években a védelmi tárca müködését érintő egyetlen komolyabb reformkísérlet 1998-ban kudarcot vallott, mivel azon politikai és katonai szereplők, akiknek a tervezett reformok a hatalmi vagy gazdasági érdekét sértették volna - az államfő támogatását is megszerezve - sikeresen fel tudtak lépni a reform blokkolása érdekében. (Mihaljevic 2012, 139-140).

Az autoriter politikai irányvonal és többek között a daytoni rendezés aláásására irányuló Bosznia-politika miatt a kilencvenes évek második felében Horvátország nemzetközileg elszigetelődött, és a kimaradt az euroatlanti integrációs folyamatokból, olyannyira, hogy még a NATO Partnerség a Békéért (PfP) programjához való csatlakozásra sem kerülhetett sor (Tanner 2001, 303-304, Edmunds 2007, 192-193).

A demokratikus civil-katonai kapcsolatok kiépítése, és az euroatlanti integrációs folyamatokba való bekapcsolódás csak Tudjman 1999 decemberi halála és a HDZ 2000 januári választási veresége után kezdődhetett meg. Az ekkor hatalomra kerülő Az akkor hatalomra kerülő baloldali koalíciós kormány helyzetét azonban nehezítették a koalíciós pártok belső vitái, valamint az, hogy az ellenzékbe szorult HDZ és eleinte a korábbi kormánypárthoz köthető katonai szereplök is élesen támadták az új kormány egyes védelempolitikai intézkedéseit (Edmunds 2007, 59$60,76,132-133)$.

A legélesebb politikai szembenállás - a Horvátország számára a NATO-tagság egyik feltételéül szabott - a hágai Jugoszlávia-törvényszékkel (ICTY) való együttműködés kapcsán alakult ki, mivel ez áttételesen a horvátországi háború megítélését is érintette (Edmunds 2007, 198-199, 202-203). 
Jelentős vitákra került sor az új védelmi miniszter és köztársasági elnök között is a fegyveres erők feletti hatáskörök megosztása kapcsán. Ebben a vitában a hadsereg új vezérkari főnöke az államfo „,politikai szövetségesévé” vált, ily módon „,bevonódott” a politikusok közötti konfliktusba (Bellamy és Edmunds 2005, 77, 83). A 2002-ben elfogadott honvédelmi törvény a fegyveres erők feletti ellenőrzési jogköröket kompromisszumos megoldásként - „megosztotta” a kormány és a köztársasági elnök között (Volten 2005, 47-48, Grubisa 2003, 24-25, 27-28, 31-32).

Az új kormány egyértelmüen elkötelezte magát a NATO-csatlakozás célja mellett, a tagsághoz szükséges feltételek teljesítése azonban kezdetben - részben a kormánykoalíció belső vitái miatt - igen lassan haladt (Szilágyi 2003, 2-3, Edmunds 2007, 59-60, Bellamy és Edmunds 2005, 75-76, 87-88). A NATO-tagságra való felkészülés során a legfontosabb politikai-szakpolitikai kihívások a minisztérium és a hadsereg létszámcsökkentése, a védelmi szféra depolitizálása, és a civil köztisztviselök arányának növelése voltak (Edmunds 2003, 20-21, 42-43).

A NATO-csatlakozáshoz szükséges reformok felgyorsítására 2003-tól, Ivo Sanader miniszterelnöksége alatt került sor, akinek a vezetése alatt a kormányzati pozícióját ekkor visszaszerző HDZ is célul tűzte az ország euroatlanti integrációját (Longo 2006, 38-40). A szükséges reformok 2004 és 2008 közötti sikeres végrehajtása, valamint az ICTY-al való együttműködés további javulása lehetővé tette, hogy Horvátország 2008-ban meghívást kapjon az atlanti szövetségbe és 2009 áprilisában a NATO tagjává váljon. Történelmi okok miatt az ország 2000-et követően sem vett részt közvetlenül a balkáni béketeremtésre irányuló nemzetközi missziókban, ezekhez jellemzően csak logisztikai támogatást nyújtott. A horvát hadsereg NATOmissziókban való részvétele így szinte kizárólag az afganisztáni ISAF-ra korlátozódott (Mahecic 2003c, 167-168, Polak et al 2009, 513, Watkins 2004, 7).

A hadsereg társadalmi elfogadottsága a kilencvenes évek többségében magas maradt, ennek megrendülésére csak az évtized végén került sor, amikor az állampolgárok egy jelentős része a fegyveres erőket a különféle pénzügyi visszaélésekkel, a korrupcióval, és az egyre népszerütlenebbé váló HDZ-rezsimmel azonosította (Edmunds 2007, 57-58). 2000 után, különösen az első évtized közepétől azonban inkább az állampolgári apátia határozta meg a védelmi-katonai kérdésekkel kapcsolatos társadalmi attitüdöket (Domjancic 2015, 171). 
A magyarázó tényezők hatását Horvátország esetében a 7. táblázat tartalmazza.

A történelmi örökség hatása - Szlovéniához képest - erősebb volt és hosszabb ideig jelentkezett. Az 1991-95 közötti horvátországi háború miatt a létrejövő horvát hadseregen belül a korábban a Jugoszláv Néphadseregben (JNH) szolgáló horvát nemzetiségü tisztek és főtisztek szerepe is kezdetben jelentősebb maradt (Lukic 2008, 194-195, Vankovska és Wiberg 2003, 180-181, Bebler 1996, 202). Ezen túlmenően a civil-katonai kapcsolatok kialakuló mintái (autoriter vagy pártkontroll) bizonyos mértékben párhuzamba állíthatók a titói időszakban tapasztaltakkal (Domjancic 2015, 171-172, Lukic 2008, 190-191). Az ezredfordulót követően azonban a történelmi örökség már csak korlátozottan játszott szerepet az általam vizsgált területen (Edmunds 2007, 75-76, Tatalovic 2010, 18-19).

A biztonsági fenyegetések a kilencvenes években voltak a legnagyobb hatással a horvátországi civil-katonai kapcsolatok alakulására, mivel az 1991-95 közötti háború mind a politikai folyamatokat, mind pedig a hadsereg szervezetét (létszámát, összetételét, az előléptetés lehetőségeit) jelentősen befolyásolta (Edmunds 2007, 121-124, Bellamy 2002b, 176-177). A háborús helyzet lehetővé tette az autoriter hatalomgyakorlási módszerek és technikák bizonyos mértékü legitimálását, illetve ebben az időszakban találkozhattunk azzal a jelenséggel is, hogy a kormányzat esetenként politikai tőkét kívánt kovácsolni a fegyveres konfliktusból: például az 1995 nyári katonai győzelmek után előrehozott választást írtak ki (Vankovska 2002, 58-59, 77, Vankovska és Wiberg 2003, 209-210, Dolenec 2013 138-140).

A kétezres évekre a hagyományos katonai fenyegetések szerepe fokozatosan háttérbe szorult, az első évtized második felében gyakorlatilag meg is szünt.

A belső politikai folyamatok szintén a kilencvenes években gyakorolták a legerősebb hatást az általam vizsgált területre, mivel ekkor a civil kontroll autoriter formái érvényesültek (Dolenec 2013, 133-134, 139-140, Bellamy 2002, 176-180).

A belső politikai folyamatok a 2000. évi politikai „rezsimváltást” követő legelső időszakban is meghatározóak voltak, részben a kormányzó balközép koalíción belüli, részben az államfö és a védelmi miniszter közötti hatásköri viták miatt (Edmunds 2007, 59-60, 75). A kormányzó pártok közötti vitákon túlmenően a védelmi szféra volt az egyik „terepe” a balközép pártok és a jobboldali ellenzéki HDZ közötti éles politikai szembenállásnak is (Edmunds 2003, 41-42, Edmunds 2007, 59-60, 132 $133)$. 
A védelmi szférát illető politikai viták az utolsó, 2003-2011 közötti időszakban némiképp háttérbe szorultak, mivel a NATO-csatlakozás alapkérdéseiről politikai konszenzus alakult ki az államfó és a kormány, illetve a horvát jobb- és baloldal között, valamint az Ivo Sanader vezette jobbközép kormánykoalíció is jóval egységesebb volt, mint 2000 és 2003 között hivatalban lévő balközép elődje (Lukic 2008, 205, Simunovic 2015, 182-183, Edmunds 2007, 60-61). Ettől függetlenül ez az időszak sem nélkülözte az éles politikai vitákat, melyek egyebek mellett a volt Jugoszlávia területén elkövetett bünöket vizsgáló hágai törvényszékkel (ICTY) való együttműködéshez kapcsolódtak (Edmunds 2007, 198-199, 202-204).

A nemzetközi szereplők és szervezetek hatása a kilencvenes években korlátozott volt: a háború alatt az országra vonatkozó ENSZ-fegyverembargó miatt kétoldalú védelmi együttmüködésre az Egyesült Államokkal csak közvetett formában, az MPRI amerikai katonai magáncégen keresztül kerülhetett sor. A Tudjman-rezsim autoriter jellege miatt az ország az euroatlanti integrációs folyamatokból a kilencvenes évek második felében is kimaradt, ekkor is a közvetett (MPRI) és a közvetlen bilaterális (kormányközi) kapcsolatok jelentettek az ország számára lehetőséget a nemzetközi védelmi együttmüködésre (Tatalovic 2010, 7, Edmunds 2007, 192-193, 198-199).

A NATO jelentősebb hatásával csak a 2000 utáni időszakban találkozhatunk: számos 2000 és 2003 között elfogadott, a védelmi szférát érintő jogszabály vagy stratégiai dokumentum tartalmát, vagy elfogadásának időzítését már a NATO-felkészülés szempontjai is befolyásolták. (Tatalovic 2010, 9, Pietz és Remillard 2006, 36).

Mégis a NATO hatása különösen a 2003-tól kezdődő periódusban erősödött fel, mivel ekkor a csatlakozáshoz szükséges reformok végrehajtására vonatkozó politikai akarat találkozott a NATO által nyújtott tagsági perspektívával. Ebben az időszakban a NATO adminisztratív apparátusa, illetve egyes NATO tagállamokból származó szakértők közvetlenül is támogatást nyújtottak a horvát külügy- és védelmi minisztériumnak a NATO-felkészüléshez szükséges stratégiai dokumentumok előkészítésében, illetve konkrét reformintézkedések megtervezésében és végrehajtásában (Edmunds 2007, 200-201, Simunovic 2015, 194, Tatalovic 2010, 13). Elsődlegesen a NATO-csatlakozás ambíciója motiválta ebben az időszakban a horvát hadsereg nemzetközi missziós szerepvállalását is, mivel a külföldre küldött horvát katonák legnagyobb része a NATO - a horvát érdekszférától távoli afganisztáni ISAF missziójában teljesített szolgálatot (Simunovic 2015, 194-195). 
7. táblázat: A vizsgált magyarázó tényezők hatása Horvátország esetében

\begin{tabular}{|c|c|c|c|c|}
\hline $\begin{array}{c}\text { Periódus és } \\
\text { jellemző példák }\end{array}$ & $\begin{array}{l}\text { TÖRTÉNELMI } \\
\text { ÖRÖKSÉG }\end{array}$ & $\begin{array}{l}\text { FENYEGETÉS- } \\
\text { PERCEPCIÓK }\end{array}$ & $\begin{array}{l}\text { BELSÖ POLITIKAI } \\
\text { FOLYAMATOK }\end{array}$ & NEMZETKÖZI SZEREPLŐK \\
\hline \multirow[b]{2}{*}{ 1991-1995 } & Érdemi & Meghatározó & Meghatározó & Kimutatható \\
\hline & $\begin{array}{l}\text { JNH doktrínák szerepe } \\
\text { JNH-minták a civil- } \\
\text { katonai kapcsolatokban } \\
\text { és a haderő } \\
\text { pártkontrolljában }\end{array}$ & $\begin{array}{l}\text { A háború, mint az } \\
\text { autoriter tendenciák } \\
\text { hivatkozási alapja } \\
\text { A hadsereg belső } \\
\text { struktúrája, előléptetés } \\
\text { módja, feltételei } \\
\text { A háború felhasználása } \\
\text { politikai célokra }\end{array}$ & $\begin{array}{l}\text { Fegyveres erök autoriter } \\
\text { civil kontrollja } \\
\text { Katonatisztek } \\
\text { párttagsága, } \\
\text { képviselöjelöltsége }\end{array}$ & $\begin{array}{l}\text { ENSZ fegyverembargó } \\
\text { hatásai } \\
\text { Közvetett amerikai-horvát } \\
\text { együttmüködés az MPRI-n } \\
\text { keresztül }\end{array}$ \\
\hline \multirow[b]{2}{*}{ 1995-1999 } & Érdemi & Érdemi & Meghatározó & Kimutatható \\
\hline & $\begin{array}{l}\text { JNH doktrínák szerepe } \\
\text { JNH-minták a civil- } \\
\text { katonai kapcsolatokban } \\
\text { és a haderő } \\
\text { pártkontrolljában }\end{array}$ & $\begin{array}{l}\text { Háborús győzelem } \\
\text { felhasználása politikai } \\
\text { célokra (1995) } \\
\text { Szerbia, mint katonai } \\
\text { fenyegetés } \\
\text { fennmaradása }\end{array}$ & $\begin{array}{l}\text { Fegyveres erők autoriter } \\
\text { civil kontrollja } \\
\text { Katonatisztek } \\
\text { párttagsága, } \\
\text { képviselőjelöltsége }\end{array}$ & $\begin{array}{l}\text { Védelmi együttmüködés } \\
\text { kétoldalú keretek között } \\
\text { MPRI tanácsadás szerepe } \\
\text { PfP csatlakozás sikertelen }\end{array}$ \\
\hline \multirow[b]{2}{*}{$2000-2003$} & Kimutatható & Kimutatható & Meghatározó & Érdemi \\
\hline & $\begin{array}{l}\text { Minősített információk } \\
\text { túlzottan széles köre } \\
\text { („titkossági } \\
\text { pszichózis”) } \\
\text { Védelmi-katonai } \\
\text { kérdésekkel foglalkozó } \\
\text { képzett civilek } \\
\text { alacsony száma }\end{array}$ & $\begin{array}{l}\text { Az ország csökkenő } \\
\text { katonai fenyegetett- } \\
\text { ségére épülő nemzeti } \\
\text { biztonsági stratégia } \\
\text { A társadalom és } \\
\text { katonai vezetés egy } \\
\text { része szkeptikus a } \\
\text { Milosevics utáni } \\
\text { Szerbiát illetően }\end{array}$ & $\begin{array}{l}\text { Védelmi miniszter és } \\
\text { köztársasági elnök } \\
\text { hatásköri vitái } \\
\text { Viták az ICTY-al való } \\
\text { együttmüködésröl } \\
\text { „Tábornokok levele” } \\
\text { incidens }\end{array}$ & $\begin{array}{l}\text { Csatlakozás a NATO } \\
\text { Békepartnerséghez (PfP) } \\
\text { Új honvédelmi törvény és } \\
\text { a Nemzeti Biztonsági } \\
\text { Stratégia elfogadása a } \\
\text { NATO MAP-ba való } \\
\text { meghívás érdekében }\end{array}$ \\
\hline \multirow[b]{2}{*}{$2003-2011$} & Kimutatható & Elhanyagolható & Érdemi & Meghatározó \\
\hline & $\begin{array}{l}\text { A NATO csatlakozással } \\
\text { és az Egyesült Államok } \\
\text { politikájával } \\
\text { kapcsolatos társadalmi } \\
\text { attitüdök }\end{array}$ & $\begin{array}{l}\text { Nem konvencionális } \\
\text { fenyegetések }\end{array}$ & $\begin{array}{l}\text { Konszenzus a NATO- } \\
\text { felkészülés főbb } \\
\text { kérdéseiröl } \\
\text { Reformok a NATO- } \\
\text { csatlakozás érdekében } \\
\text { Viták az ICTY-al való } \\
\text { együttmüködésröl és } \\
\text { Gotovina tábornok ügye }\end{array}$ & $\begin{array}{l}\text { NATO elvárások szerinti } \\
\text { Stratégiai dokumentumok } \\
\text { Magas szintű személyes } \\
\text { kapcsolatok horvát és } \\
\text { NATO szereplők között } \\
\text { NATO tervezési rendszer } \\
\text { bevezetése } \\
\text { Fokozottabb részvétel } \\
\text { NATO és EU missziókban }\end{array}$ \\
\hline
\end{tabular}

Forrás: saját szerkesztés 


\section{8. Összegzés és következtetések}

\subsection{A szlovén és horvát eset hasonlóságai és különbségei}

A két ország összehasonlítását négy alapvető szempont szerint érdemes megtenni: vizsgálom a haderő létrejöttének módját, személyi hátterét, belső felépitését, másodsorban a hadsereg és a politika közötti kapcsolatot különösen intézményi-jogi szempontból, harmadrészt a hadsereg társadalmi szerepét és társadalmi megitélését, végezetül pedig a haderö-átalakitás és a NATO-tagságra való felkészülés főbb problémáit és kihívásait a kétezres években.

Mind a szlovén, mind pedig a horvát haderőt az adott ország függetlenné válása során, újonnan hozták létre. A későbbi Szlovén Hadsereg alapját a köztársasági Területvédelem képezte, míg a Horvát Hadsereg a rendőrség, illetve a különleges rendőri egységekből megalakított Nemzeti Gárda $(\mathrm{ZNG})$ bázisán jött létre (Juhász 1999, 239-240, Lukic 2008, 192-193). Mindkét fegyveres erő személyzete heterogén volt az 1990-es évek során: mind a szlovén, mind a horvát hadseregben megtalálhatók voltak a JNH, és a köztársasági Területvédelem katonái és tisztjei, valamint jelentős számú civil önkéntes. Horvátország esetében viszont sajátos elemet képezett a diaszpórából származó, korábbi katonai tapasztalattal rendelkezők (például korábbi francia idegenlégiósok) jelenléte (Bebler 1996, 208-210, Vankovska és Wiberg 2003, 173-174, Lukic 2008, 193-194).

Közös pontot képezett a két hadsereg között a nagy számú, korábbi katonai képzettséggel, tapasztalattal nem rendelkező civil „beáramlása”, valamint a feszültségek a korábbi JNH-múltú tisztek és az állomány többi része között. Eltérő okokból, de mind Szlovéniában, mind Horvátországban igyekeztek a hadseregen belül a korábban a JNH-ban szolgált tiszteket és tábornokokat háttérbe szorítani, ugyanakkor a kilencvenes évek első felében a háborús szükségszerüség miatt e tisztek a horvát hadseregben jelentősebb szerepet játszottak (Edmunds 2007, 124125, Lukic 2008, 193-196). A JNH szlovén származású fötisztjeinek alacsony száma és esetenként az új államhoz való kérdéses lojalitása miatt a korábbi JNH főtisztek közül igen kevés - a tábornokok közül például egy sem - került át az új szlovén hadseregbe (Vankovska és Wiberg 2003, 180-181, Bebler 1996, 202).

A szlovén hadsereg haderőstruktúrája (force structure) a kilencvenes években továbbra is inkább a Területvédelem sajátosságait tükrözte (könnyü fegyverzetü, 
milícia jellegű erő), míg a horvát hadsereg a kilencvenes évek közepén, létszámát, képességeit, belső felépítését tekintve közelebb állt a korábbi Varsói Szerződés európai tagállamainak tömeghadseregeihez (Edmunds 2007, 125).

A hadsereg és a politika viszonyát illetően megjegyzendő, hogy a haderő civil kontrollja egyik vizsgált államban és egyik időszakban sem kérdőjeleződött meg, noha a tudjmani Horvátországban a fegyveres erők autoriter és nem demokratikus civil kontrollja valósult meg (Horowitz 2005, 162-163, Edmunds 2007, 54, Bellamy 2002, 177). Szlovéniával ellentétben Horvátországban gyakorlatilag két demokratikus átmenetre került sor (Domjancic 2015, 169-170): először 1990-ben a kommunista egypártrendszerről a többpártrendszerre, majd pedig 2000-ben a Goran Čular horvát politológus által „autoriter demokráciának” (Cular 2000, 37) nevezett tudjmani berendezkedésről a liberális demokráciára. Így a demokratikus civil-katonai kapcsolatok legtöbb elemének kiépítése csak 2000-től kezdődött.

Szlovéniában a demokratikus civil kontroll intézményeinek kiépítése a kilencvenes évek elején megtörtént, ugyanakkor a kialakulatlan jogi keretek miatt az 1991-1994es időszakban több hatásköri vitára került sor a köztársasági elnök és a védelmi miniszter között, melybe időről-időre a katonai vezetés bizonyos tagjai is „bevonódtak” (Malesic 2006, 146, Bebler 1996, 206-210). A fenti vitákat az 1994ben elfogadott honvédelmi törvény nagy mértékben rendezte, a fegyveres erők feletti felügyeletet a törvény alapvetően a kormányhoz és a védelmi miniszterhez „telepítette” (Szilágyi 2002, 64-65, 71-72). Horvátországban hasonló vitára került sor a 2000-es „rezsimváltás” utáni első években, melynek föszereplöje a védelmi miniszter, illetve a köztársasági elnök és „politikai szövetségese”, Petar Stipetić vezérkari főnök volt. A vita a végrehajtó hatalom két szereplöje közötti szembenálláson túlmenően a HDZ-kormányt váltó sokpárti koalíció belső feszültségeit is tükrözte (Bellamy és Edmunds 2005, 77, 83, Edmunds 2007, 59-60). A 2002-ben elfogadott honvédelmi törvény kompromisszumos megoldás eredménye volt, mely a fegyveres erők feletti ellenőrzési jogköröket „megosztotta” a kormány és a köztársasági elnök között (Grubisa 2003, 27-28, 31-34). A horvát parlament a végrehajtó hatalomhoz képest a 2000-et követő időszakban is gyengébb szerepet játszotta a fegyverek erők demokratikus ellenőrzésében, melyet jól mutat az is, hogy az önálló védelmi szakbizottságot csak 2008-ban állították fel (Edmunds 2007, 71, Tabak 2011, 88). 
A szlovéniai civil-katonai kapcsolatokat az időszak egészében a civilek dominanciája jellemezte, a hivatásos katonai szakma érdekérvényesítő képessége, különösen a kilencvenes években, elhanyagolható volt, és a sorkötelezettség kivezetéséről szóló szakmai vita a kétezres évek elején arról tanúskodik, hogy ez a helyzet érdemben később sem változott (Bebler 2004, 128-130, Malesic 2017, Jelusic 2017). A minisztérium és az igazgatási apparátus átalakítása során a minisztériumban dolgozó katonák túl alacsony aránya jelentette az egyik problémát (Furlan 2013, 443).

Horvátországban a katonák pozíciója kezdettől fogva erősebb volt, de mint Stjepan Domjancic megjegyzi, a hadsereg létrejöttének sajátos módja (háborús körülmények között, nagy számú, katonai képzettséggel nem rendelkező civil csatlakozásával) és az uralkodó pártnak való alárendeltsége miatt szakmai „lobbi” a katonaságon belül nem tudott létrejönni (Domjancic 2015, 171, 173)

Noha a társadalmi bizalom a szlovén fegyveres erőkben mindvégig magas volt, de ez nem párosult a katonai szakma társadalmi presztízsével, valamint azzal, hogy az állampolgárok részt is kívánnak venni a honvédelemben. Erre utal a sorkatonaság intézményének válságba kerülése a 2000-es évek elejére és a lelkiismereti szolgálatmegtagadók magas aránya (Bebler 2000, 147, Jelusic 2005, 83).

A kétezres években egyes missziós szerepvállalások (különösen az afganisztáni) jelentős társadalmi elutasítottsága, valamint az a befolyásos értelmiségiek és újságírók által kezdeményezett 2010-es petíció, mely az állandó hadsereg izlandi mintára történő eltörlését kívánta volna elérni (Svete 2011, Malesic et al 2015, 118 , 121-122), azt mutatja, hogy a hadseregellenes és pacifista attitüdök továbbra is erősen jelen vannak a szlovén társadalomban. Malesic (2017) arra mutat rá, hogy a kétezres évek katonai beszerzésekkel kapcsolatos korrupciós botrányainak (különösen a Patria-ügy) főszereplői a politikai osztály tagjai és civil köztisztviselők voltak, ezen botrányok mégis elsősorban a hadsereg társadalmi megítélését érintették negatívan.

A hadsereg társadalmi elfogadottsága Horvátországban a kilencvenes évek folyamán többnyire magas maradt, ennek megrendülésére csak az évtized végén került sor, amikor az állampolgárok egy jelentős része a fegyveres erőket a különféle pénzügyi visszaélésekkel, a korrupcióval, és az egyre népszerütlenebbé váló HDZ-rezsimmel azonosította (Edmunds 2007, 57-58). A kétezres években, különösen az évtized közepétől azonban inkább az érdektelenség határozta meg a védelmi-katonai kérdésekkel kapcsolatos társadalmi attitüdöket (Domjancic 2015, 171). 
Mind a szlovén, mind pedig a horvát esetben a NATO-tagságra történö felkészülés a területvédelmi felfogásról egy kollektív védelmi felfogásra épülö, könnyen mozgósítható, külföldi bevetésekre bizonyos keretek között alkalmazható haderő felé történő „elmozdulást” jelentette. Horvátország esetében azonban ennek érdekében jelentős létszámcsökkentés vált szükségessé, mely probléma Szlovénia esetén nem, vagy csak igen korlátozottan jelentkezett. Az említett „létszámfelesleg” Horvátország esetében nem csak a hadsereget, hanem a minisztériumi apparátust is jellemezte.

A horvát hadsereg személyzeti struktúrája a kétezres évek első évtizedének első felében továbbra is magán hordozta a háborús időszak örökségét: kedvezőtlen volt az átlagos életkor, a szervezet alapvetően „fejnehéz” volt, ezen túlmenően számos tiszt nem rendelkezett a pozíciója és rendfokozata alapján elöírt képzettséggel vagy iskolai végzettséggel sem (RoC Ministry of Defence 2005, 7, 33-34, 38-39, Bellamy 2002 182-183). Horvátország további sajátossága volt, hogy a korábbi helyzet miatt, amikor a védelmi minisztérium tisztviselői jelentős részben aktív állományú katonákból álltak, a civil köztisztviselők alacsony száma jelentette a fő kihívást (Grubisa 2003, 30, Mahecic 2003, 59, Edmunds 2003, 20-21). Mindkét ország esetében elmondható, hogy a minisztérium átalakításának üteme elmaradt a hadsereg szervezeti modernizálásának ütemétől. Hasonló problémákról beszélhetünk a hadsereg strukturális és funkcionális professzionalizálása esetén: mindkét országban sor került a strukturális professzionalizálásra (az önkéntes haderő bevezetésére), ugyanakkor a funkcionális professzionalizáció, a fegyveres erők müködésének professzionálisabbá tétele sokkal kevésbé volt sikeres (Jelusic 2014, Grizold 2014, Ministarstvo obrane RH 2010, 59, RoC Ministry of Defence 2013, 33-34).

Huntington objektív kontroll fogalmának felhasználásával vizsgálva a szlovén esetet, Furlan $(2013,440)$ azt állapítja meg, hogy noha minden feltétele adott Szlovéniában a fegyveres erők feletti objektív civil kontroll müködéséhez, a fegyveres erők feletti civil és demokratikus kontroll gyakorlati megvalósítása (a civilek már említett „túlzott dominanciája”) gátolja annak érvényesülését. Domjancic $(2015,173)$ szintén arra mutat rá, hogy a huntingtoni értelemben vett professzionalizmus kialakulásának a kilencvenes évekbeli Horvátországban nem voltak meg a feltételei, így a civilkatonai kapcsolatok „nyugati” mintái sem alakulhattak ki.

A Desch nevével fémjelzett strukturális realista modell feltevéseit kutatásom Szlovénia esetében csak részlegesen igazolta. A kezdeti időszakban, amikor az 
ország jelentős külső fenyegetettséggel nézett szembe (előbb a szlovéniai háború, majd a környezetében zajló délszláv konfliktusok miatt), a modell feltevéseivel összhangban a haderő feletti civil kontroll erös volt, azonban megítélésem szerint ez sokkal inkább köszönhető a sajátos szlovéniai belső sajátosságoknak (különösen a védelmi szektorban meglévő civil dominanciának), mintsem a biztonsági fenyegetés mértékének. Az ezt követő időszakokban mind a külső mind pedig a belső fenyegetettség alacsony volt, a kutatás eredményei alapján a modellel összhangban szintén erős civil kontrollal találkozhatunk, mely a modell feltevései alapján koordinációs problémáktól terhelt lehet. A civil és a katonai vezetés közötti koordinációs problémák meglétére a szlovén eset vizsgálatakor találtam bizonyítékot (Jelusic 2017, Grizold 2014), ugyanakkor a rendelkezésemre álló adatok alapján nem találtam oksági kapcsolatot a szlovéniai civil-katonai kapcsolatokban meglévő koordinációs problémák és a biztonsági fenyegetés mértéke között.

Horvátország esetében a modell feltevéseit kutatásom szintén csak részlegesen igazolta. Tekintve, hogy az 1991 és 1995 közötti időszakban az országnak mind belső (a krajinai szerbek felkelése), mind pedig külső fenyegetéssel szembe kellett néznie (1991-ben a jugoszláv szövetségi hadsereg támadása az ország ellen, majd pedig a szerbiai és boszniai szerb erők által jelentett katonai fenyegetés), a modell feltevései szerint a várható civil kontroll mértéke közepes, mely során esetlegesen a civil és katonai vezetés között konfliktusok tapasztalhatóak (Desch 1999, 15-17).

A civil és a katonai vezetés közötti konfliktusokra 1991 őszén találtam bizonyítékot (lásd a 7.2.1. alfejezetben) azonban nem teljesült a modell feltevései közül az, hogy a civil vezetés megosztott lesz (különösen 1991-1992-ben a politikusok feltünő egységet mutattak, tekintve, hogy 1991 és 1992 nyara között nemzeti egységkormány állt fenn). Mint azt a horvát esettanulmány 7.2. és 7.3. fejezetében említettem, a tudjmani időszak egyik pontján sem kérdőjeleződött meg a haderő civil kontrollja, mely a modell feltevéseivel alapvetően konzisztensnek tekinthető.

A kétezres években, amikor az ország alacsony és belső fenyegetettséggel nézett szembe, a kutatás eredményei alapján a horvát esetben a modellel összhangban szintén erős civil kontrollal találkozhatunk. Hasonlóan a szlovén esethez, találtam bizonyítékot a modell által előrejelzett, a civil és katonai vezetés közötti koordinációs problémákra a 2000-2003 és a 2003-2011 periódusban, de a rendelkezésemre álló adatok alapján ebben az esetben sem találtam oksági kapcsolatot a koordinációs problémák és a biztonsági fenyegetés mértéke között. 


\subsection{A legfontosabb kutatási eredmények összegzése}

Az 1.2. fejezetben megfogalmazott kutatási kérdések és magyarázó tényezők alapján dolgozatom föbb következtetései az alábbiakban összegezhetőek:

1./ A jugoszláv történelmi örökség mindkét esetben gyakorolt hatást a vizsgált területen. Szlovénia esetében ez a hatás kevésbé volt jelentős és inkább közvetetten jelentkezett. A szlovén haderő az egykori Területvédelem bázisán jött létre, melynek müködési módja, felépítése, doktrínája a kezdetekben befolyásolta a szlovén hadsereg és védelmi szektor belső folyamatait is (Malesic és Jelusic 2005, 211-212). Ezen túlmenően az 1991-es rövid háború során a szlovénok több tekintetben az 1968-as „össznépi védelem” doktrínájának bizonyos elemeit használták fel a Jugoszláv Néphadsereggel szembeni ellenállás megszervezése során (Horncastle 2013). A jugoszláv örökség szerepet játszott ugyanakkor „negatív” formában is.

A szlovén demokratizációs és függetlenedési folyamatokban fontos szerepet játszott a Jugoszláv Néphadsereggel (JNH) szembeni ellenérzés (Gow 1992, 78-88), részben emiatt. a függetlenség elnyerését követően számos területen a védelmi-katonai szférára vonatkozó szabályozás (például a lelkiismereti szolgálatmegtagadás európai viszonylatban is megengedő szabályozása), kifejezetten a jugoszláv gyakorlattal történő éles különbségtétel szándékát tükrözte (Jelusic 2002, 112-113).

Horvátországban a történelmi örökség hatásai erősebbek voltak és hosszabb távon is jelentkeztek. Stjepan Domjančić (2015, 171-172) sajátos horvát paradoxonként említi, hogy a Horvát Hadsereg (HV) egyfelől a JNH, vagy a JNH által támogatott, kiképzett, és felszerelt erők ellen harcolt, sikerei mégis részben JNH-doktrínákra alapultak, illetőleg a kormányzathoz, politikához és a társadalomhoz való viszonyában is sok esetben a JNH jelentette a mintát. Reneo Lukić (2008, 190-191) szintén arra mutat rá, hogy a civil-katonai kapcsolatok a tudjmani Horvátországban bizonyos mértékig párhuzamba állíthatóak a titói Jugoszláviát jellemzőkkel, Alex J. Bellamy (2002, 178, 2003, 193-194) pedig azt említi, hogy a titói Jugoszláviához hasonlóan a hadsereget felhasználták az állam és a politikai rendszer legitimálására.

2./ Egyértelmü összefüggést találtam a két országban lezajlott fegyveres konfliktus eltérő időtartama és intenzitása, valamint a civil-katonai kapcsolatokra és a haderő demokratikus kontrolljára gyakorolt hatásai között. Szlovéniában a rövid fegyveres konfliktus tapasztalatai befolyásolták ugyan a haderőre vonatkozó elképzeléseket, illetve a tíznapos háborúban részt vevő, sokszor katonai képzettséggel korlátozott mértékben, vagy egyáltalán nem rendelkező parancsnokok a kilencvenes években több esetben vezető pozíciót töltöttek be a szlovén hadseregben, de a konfliktus a 
demokratikus civil-katonai kapcsolatok kialakulását nem befolyásolta (Kotnik és Kopac 2002, 152).

Horvátországban ezzel szemben az elhúzódó konfliktus felerősítette az államfo, Franjo Tudjman vezetési stílusában már a háború kitörését megelőzően meglévő (Meier 1999, 147, Ramet 2010, 259) autoriter elemeket, továbbá a fegyveres konfliktus bizonyos rendkívüli intézkedéseket önmagában is szükségessé tett. Ezen túlmenően a háborúra és a nemzetbiztonsági szempontokra való hivatkozás az autoriter vezetési mód legitimizálását is lehetővé tette, illetve növelte az átláthatatlanság és titkosság szerepét a védelmi szféra irányításában (Horowitz 2005, 161-162, Vankovska 2002, 58-59, Vankovska és Wiberg 2003, 209-210).

Mindkét ország esetében találkozhatunk a fegyveres konfliktus, mint az állam „eredetmítosza” szerepkörével: a szlovéniai konfliktus, igen rövid időtartama ellenére, a fiatal állam egyik korai legitimációs bázisává vált (Malesic és Jelusic 2005, 211-212). Ez a jelenség sokkal tartósabb és sokkal erőteljesebb volt Horvátország és az 1991-1995-ös horvátországi háború esetében.

A már említett Domjančić $(2015,171)$ szerint a JNH és a Horvát Hadsereg, illetve a tudjmani Horvátország és a titói Jugoszlávia közötti hasonlóság egyfajta „emlékezetpolitikai” szempontból is megfigyelhető. Ahogyan a jugoszláv periódusban az 1941-1945-ös partizánháború az állami propaganda által teremtett „mítoszának” a JNH volt az igazi letéteményese, a „Honvédő Háború” (domovinski rat), mint a tudjmani rendszer egyfajta „eredetmítosza”, legfontosabb legitimációs alapja összekapcsolódott a horvát hadsereggel (Bellamy 2002, 181-182).

3./ A horvátországi Tudjman-rezsim autoriter jellege egyértelmüen befolyásolta a civil-katonai kapcsolatokat is a kilencvenes évek során. Noha a haderő civil kontrollja a háborús helyzet ellenére sem kérdőjeleződött meg, ebben az időszakban autoriter és nem demokratikus civil kontroll valósult meg (Horowitz 2005, 162-163, Edmunds 2007, 54, Bellamy 2002, 177). Ennek föbb jellemzői az elnöki hatalomkoncentráció, a hadsereg feletti pártellenőrzés, formális vagy informális csatornákon keresztül a katonák pártpolitikai tevékenysége, az informális vagy párhuzamos parancsnoki struktúrák létezése, a parlament korlátozott vagy minimális szerepe, valamint a pénzügyi és szakpolitikai átláthatóság hiánya voltak (Dolenec 2013, 133-134, 138-140, Bellamy 2002b, 176-177, 179-180).

Beszélhetünk még ezen túlmenően a hadsereg politikai-pártpolitikai célokra való felhasználásáról is, melynek olyan példáit is megemlíthetjük, mint egyes magas rangú tábornokok HDZ-képviselőjelöltsége, a szavazók hazafias érzelmeire történő „apellálás” érdekében (Vankovska 2002, 58-59, Zunec 1996, 226). 
Szlovéniában a haderő feletti kontroll demokratikus keretei kezdettől fogva érvényesültek, ez azonban nem jelentette azt, hogy időnként ne került volna sor olyan törekvésekre, melyekkel egyes politikai szereplök a katonai vezetőket politikai „hátországuk” részévé kívánták tenni. Az 1991 és 1994 közötti, az államfő és a védelmi miniszter közötti viták során erre többször is volt példa (Malesic 2006, 146, Bebler 1996, 206-210).

4./ Az euroatlanti integráció eltérő perspektívája által gyakorolt hatást világosan ki tudtam mutatni a két ország esetében A kutatásom eredménye szerint a NATO akkor képes a legnagyobb hatást kifejteni az érintett ország belső szakpolitikai folyamataira, ha találkozik a csatlakozás követelményeinek teljesítésére vonatkozó belső politikai akarat, illetve a NATO által az adott ország számára felkínált hiteles, rövid távú csatlakozási perspektíva. Mindkét országban akkor volt a NATO hatása a legjelentősebb az általam vizsgált területen (Szlovéniában 2000-2004 között, Horvátországban pedig 2004 és 2008 között), amikor mind a két fent említett feltétel teljesült. Ezekben az időszakokban mind Szlovénia, mind pedig Horvátország esetében arról is beszélhetünk, hogy létrejött egy, NATO és helyi szereplökböl álló „transznacionális koalíció” (Epstein 2005, 69-70), mely hozzájárult a csatlakozáshoz szükséges reformok sikeres végrehajtásához.

Amikor sem az érintett ország részéről nem volt érdemben politikai akarat a NATO által szabott feltételek teljesítésére (a NATO-hoz való közeledés szándékának deklaratív megfogalmazásán túlmenően), sem pedig a NATO nem kínált tagsági perspektívát az ország számára, a NATO nem volt érdemben hatással a vizsgált területre. Erről beszélhetünk Horvátországban a kilencvenes évek során, különösen 1996 és 1999 között, a horvát államfő ugyanis előbbi időpontban fogalmazta meg először az ország NATO-hoz való közeledési szándékát (Simunovic 2015, 192).

Végezetül, amikor a csatlakozni kívánó ország részéről alapvetően jelen van a politikai akarat a feltételek teljesítésére, de a NATO által kínált tagsági perspektíva nem rövid távú, a NATO által gyakorolt hatás érvényesül ugyan, de ez korlátozottabb, mint az első esetben. Ez a helyzet Szlovéniában 1994-95 és 2000, Horvátországban pedig 2000 és 2003-2004 között volt jellemző.

Összességében tehát elmondható, hogy az általam vizsgált valamennyi tényező hatása kimutatható volt a szlovén és a horvát civil-katonai kapcsolatok alakulásában, $\mathrm{s}$ bár a két ország e téren végbement változásai hosszabb távon konvergenciát mutatnak, az egyes időszakokban többnyire tetten érhető volt a múlt öröksége, a katonai konfliktus jellege és az euroatlanti csatlakozás esélye terén meglévő különbségek eltérő következménye. 


\section{I. függelék: A kutatás során készített interjúk listája}

1. Uroš Svete, szlovén biztonság- és védelempolitikai szakértő.

Ljubljana, 2011. június 13.

2. Magyar EU szakdiplomata. Brüsszel, 2012. január 24.

3. Magyar katonadiplomata. Brüsszel, 2012. január 26.

4. Magyar NATO szakdiplomata. Brüsszel, 2012. május 24.

5. Anton Grizold, egyetemi tanár, biztonság- és védelempolitikai szakértő, korábbi szlovén védelmi miniszter (2000-2004). Ljubljana, 2014. március 4.

6. Ljubica Jelušič, egyetemi tanár, biztonság- és védelempolitikai szakértő, korábbi szlovén védelmi miniszter (2004-2008). Ljubljana, 2014. március 5.

7. Ljubica Jelušič, egyetemi tanár, biztonság- és védelempolitikai szakértő, korábbi szlovén védelmi miniszter (2004-2008). Ljubljana, 2017. október 23.

8. Marjan Malešič, egyetemi tanár, biztonság- és védelempolitikai szakértő. Ljubljana, 2017. október 24.

9. Erik Kopač, biztonság- és védelempolitikai szakértő, Miro Cerar szlovén miniszterelnök biztonságpolitikai tanácsadója. Ljubljana, 2017. október 26. 


\section{Irodalomjegyzék}

Abrahamsson, Bengt. 1972. Military Professionalization and Political Power. London: Sage.

Agüero, Felipe. 1995. Soldiers, civilians and democracy. Post-Franco Spain in comparative perspective. Baltimore; London: Johns Hopkins University Press.

AIM Press. 1997. „Extorted patching up of the state policy”. AIM Press. 1997. március 11. http://www.aimpress.ch/dyn/trae/archive/data/199703/70316006-trae-zag.htm. Letöltve: 2018.04.06.

Albright, David E. 1980. „Comparative Conceptualization of Civil-Military Relations". World Politics 32 (4): 553-76. https://doi.org/10.2307/2010057.

Almond, Gabriel, és Sidney Verba. 1963. The Civic Culture. Princeton: Princeton University Press.

Andreski, Stanislav. 1954. Military Organization and Society. London: Routledge \& Kegan Poul.

Antic, Zdenko. 1972. „National composition of the Yugoslav army leadership”. Background Report No. 262. München: Radio Free Europe / Radio Liberty.

Arnejcic, Beno, és Igor Vuk. 2001. „Civil-military relations in Slovenia: aspects, factors, problems". In Civil-Military Relations in Southeast Europe, szerk. Plamen Pantev, 175-205. Vienna: National Defense Academy.

Avant, Deborah. 1998. „Conflicting indicators of »crisis « in American civil-military relations". Armed Forces \& Society 24 (3): 375-88. https://doi.org/10.1163/1871191x-12341234.

Barany, Zoltan D. 1992. „East European Armed Forces in Transitions and Beyond”. East European Quarterly 26 (1): 1-30.

1993. Soldiers and Politics in Eastern Europe, 1945-1990. New York: St. Martin's Press. 2003. The future of NATO expansion: four case studies. Cambridge; New York: Cambridge University Press.

- 2012. The soldier and the changing state. Princeton: Princeton University Press.

Baric, Slavko. 2006. „The Croatian Armed Forces and NATO”. Shrivenam: Conflict Studies Research Centre, Defense Academy of the United Kingdom.

Beach, Derek, és Rasmus B. Pedersen. 2013. Process-Tracing Methods. Foundations and Guidelines. Ann Arbor: University of Michigan Press.

Bebler, Anton. 1991. „The military and the Yugoslav crisis”. Südosteuropa 40 (3-4): 127-44. 1993a. „Political Pluralism and the Yugoslav Professional Military”. In The tragedy of Yugoslavia: the failure of democratic transformation, szerk. Jim Seroka és Vukasin Pavlovic, 105-40. Armonk, NY: M.E. Sharpe.

. 1993b. „Slovenia's territorial defence”. Jane's International Defense Review 1993 (1): 65-67.

. 1994. „Civil-Military Relations in the Central-East European States in Transition”. Journal of International Relations (Ljubljana) 2 (4): 143-52. . 1996. „Civil-Military Relations in Slovenia”. In Civil-Military Relations in the Soviet and Yugoslav Successor States, szerk. C. Danopoulos és D. Zirker, 195-211. Boulder (Colo.): Westview Press. 
1999a. „A Research Note on Elegibility for NATO Membership”. In The challenge of NATO enlargement, szerk. Anton Bebler, 49-57. Westport, CT; London: Praeger.

. 1999b. „Slovenia and the »Gray Zone« in Europe”. In The challenge of NATO enlargement, szerk. Anton Bebler, 151-58. Westport, CT; London: Praeger.

1999c. „Slovenia and NATO Enlargement”. International Journal 55 (1): $125-37$.

2000. „The public's role in the democratic control of armed forces in Slovenia". In International security, mass media and public opinion, szerk. Marjan Malesic, 140-48. Ljubljana: Faculty of Social Sciences, University of Ljubljana.

2002. „Democratic Control of Armed Forces in Slovenia”. In Democratic Control of the Military in Postcommunist Europe: Guarding the Guards, szerk. Andrew Cottey, Timothy Edmunds, és Anthony Forster, 159-73. Houndmills: Palgrave.

. 2004a. „Civil-military Relations and Democratic Control of the Armed Forces in Slovenia". In Renaissance of democratic control of armed forces in contemporary societies, szerk. Hans Born, Marjan Malesic, és Karl Haltiner, 121-31. Baden-Baden: Nomos Verlag. . 2004b. „Der Prozess der NATO-Erweiterung, demokratische Werte und Slowenien". In Die zweite Runde der NATO-Osterweiterung: zwischen postbipolarem Institutionalismus und offensivem Realismus, szerk. August Pradetto, 213-36. Frankfurt: Lang.

Bebler, Anton, és Milan Jazbec. 2010. „Slovenia and NATO enlargement”. In NATO at 60 - The Post-Cold War Enlargement and the Alliance's Future, szerk. Anton Bebler, 49-61. Amsterdam: IOS Press.

Bellamy, Alex J. 2001. „Croatia After Tudjman: The 2000 Parliamentary and Presidential Elections". Problems of Post-Communism 48 (5): 18-31. https://doi.org/10.1080/10758216.2001.11655948. . 2002. „'Like Drunken Geese in the Fog': Developing Democratic Control of Armed Forces in Croatia". In Democratic Control of the Military in Postcommunist Europe: Guarding the Guards, szerk. Andrew Cottey, Timothy Edmunds, és Anthony Forster, 174-93. Houndmills: Palgrave. . 2002b. „A Revolution in Civil-Military Affairs: the Professionalisation of Croatia's Armed Forces". In The Challenge of Military Reform in PostCommunist Europe: Building Professional Armed Forces, szerk. Anthony Forster, Timothy Edmunds, és Andrew Cottey, 165-82. Houndmills: Palgrave Macmillan. . 2003. „A Crisis of Legitimacy: the Military and Society in Croatia”. In Soldiers and Societies in Post-Communist Europe: Legitimacy and Change, szerk. Anthony Forster, Timothy Edmunds, és Andrew Cottey, 185-202. London: Palgrave Macmillan.

Bellamy, Alex J., és Timothy Edmunds. 2005. „Civil-military Relations in Croatia: Politicisation and Politics of Reform”. European Security 14 (1): 71-93. https://doi.org/10.1080/09662830500042338.

Benedek, Márta. 2015. „A horvát nemzetbiztonsági szféra változásai a külpolitikai folyamatok tükrében". Felderitő Szemle 14 (4): 50-70.

Betz, David, és John Löwenhardt. 2001. Army and State in postcommunist Europe. London: Cass. 
Bland, Douglas L. 1995. „Protecting the Military from Civilian Control: A Neglected Dimension of Civil-Military Relations." In Democratic and Civil Control Over Military Forces - Case Studies and Perspectives., szerk. Ernest Gilman és Detlef E. Herold, 107-27. Rome: NATO Defense College.

- 1999. „A Unified Theory of Civil-Military Relations”. Armed Forces \& Society 26 (1): 7-26. https://doi.org/10.1177/0095327x9902600102.

- 2001. „Patterns in Liberal Democratic Civil-Military relations”. Armed Forces \& Society 27 (4): 525-40. https://doi.org/10.1177/0095327x0102700402.

—.2006. „Átfogó elmélet a civil-katonai kapcsolatok megértéséhez”. In Civilkatonai kapcsolatok: a tudomány határán: válogatás a hidegháború utáni szakirodalomból, szerk. Molnár Ferenc, 111-30. Budapest: Zrínyi.

Blum, Daniel. 2002. Sprache und Politik: Sprachpolitik und Sprachnationalismus in der Republik Indien und dem sozialistischen Jugoslawien, (1945-1991). Würzburg: Ergon.

Bojinović Fenko, Ana, és Ana Urlic. 2015. „Political Criteria vs. Political Conditionality: Comparative analysis of Slovenian and Croatian European Union accession processes". Croatian International Relations Review 21 (72): 107-37. https://doi.org/10.1515/cirr-2015-0004.

Born, Hans et al. 2006a. „Civilians and the Military in Europe”. In Civil-Military Relations in Europe: Learning from Crisis and Institutional Change, szerk. Hans Born, Marina Caparini, Karl Haltiner, és Jurgen Kuhlmann, 3-17. Abingdon: Routledge.

. 2006b. „Patterns of democratic governance of civil-military relations”. In Civil-Military Relations in Europe: Learning from Crisis and Institutional Change, szerk. Hans Born, Marina Caparini, Karl Haltiner, és Jurgen Kuhlmann, 235-55. Abingdon: Routledge.

Bruneau, Thomas C. 2013a. „Impediments to the accurate conceptualization of civilmilitary relations". In The Routledge Handbook of Civil-Military Relations, szerk. Thomas C. Bruneau és Florina C. Matei, 13-21. New York: Routledge. . 2013b. „Development of an approach through debate”. In The Routledge Handbook of Civil-Military Relations, szerk. Thomas C. Bruneau és Florina C. Matei, 22-25. New York: Routledge. . 2013c. „Efficiency in the use of resources”. In The Routledge Handbook of Civil-Military Relations, szerk. Thomas C. Bruneau és Florina C. Matei, 3947. New York: Routledge.

Bruneau, Thomas C., és Florina C. Matei, szerk. 2013. The Routledge Handbook of Civil-Military Relations. New York: Routledge.

Bucar, Bojko, és Primoz Sterbenc. 2002. „Relations between Large and Small States in a Multilateral Context: A Case Study of U.S.-Slovenian Relations Concerning NATO”. In Small states in the post-Cold War world: Slovenia and NATO enlargement, szerk. Charles Bukowski és Zlatko Sabic, 103-27. Westport, CT; London: Praeger.

Burdelez, Misan, és Dragan Lozancic. 1998. „A Brief Review of Civil-Military Relations in the Republic of Croatia". Politicka Misao 25 (5): 36-56.

Burg, Steven L., és Paul S. Shoup. 2015. The War in Bosnia-Herzegovina: Ethnic Conflict and International Intervention. London; New York: Routledge.

Burk, James. 2002. „Theories of Democratic Civil-Military Relations”. Armed Forces \& Society 29 (1): 7-29. https://doi.org/10.1177/0095327x0202900102. 
Cehulic, Lidija, és Radovan Vukadinovic. 2001. „Development of Civil-Military Relations in Croatia". In Civil-Military Relations in Southeast Europe, szerk. Plamen Pantev, 63-88. Vienna: National Defense Academy.

Central Intelligence Agency. 2002. Balkan Battlegrounds: A Military History of the Yugoslav Conflict, 1990-1995. Volume I. Washington, D.C.: Central Intelligence Agency.

2003. Balkan Battlegrounds: A Military History of the Yugoslav Conflict, 1990-1995. Volume II. Washington, D.C.: Central Intelligence Agency.

Cigar, Norman. 1997. „Croatia's war of independence: The parameters of war termination". Journal of Slavic Military Studies 10 (2): 34-70. https://doi.org/10.1080/13518049708430289.

Cohen, Lenard J. 1995. Broken bonds: Yugoslavia's disintegration and Balkan politics in transition. 2nd ed. Boulder (Colo.): Westview Press.

- 1997. „Embattled democracy: postcommunist Croatia in transition”. In Politics, power, and the struggle for democracy in South-East Europe, szerk. Karen Dawisha és Bruce Parrott, 69-122. Cambridge: Cambridge University Press.

Colton, Timothy. 1978. „The Party-military connection: a participatory model”. In Civil-military relations in Communist systems, szerk. Dale R. Herspring és Ivan Volgyes, 53-75. Boulder (Colo.): Westview Press.

Congressional Research Service. 2009. „NATO Enlargement: Albania, Croatia, and Possible Future Candidates". RL34701. Washington, D.C.: Congressional Research Service. https://fas.org/sgp/crs/row/RL34701.pdf. Letöltve: 2018.04.03.

Constitution of the Republic of Croatia. 2014. „Consolidated text as of 15 January 2014". Constitutional Court of the Republic of Croatia.

https://www.usud.hr/sites/default/files/dokumenti/The_consolidated_text_of_ the_Constitution_of_the_Republic_of_Croatia_as_of_15_January_2014.pdf. Letöltve: $2018.0 \overline{3} .2 \overline{3}$.

Cottey, Andrew, Timothy Edmunds, és Anthony Forster. 2002a. „Introduction: the Challenge of Democratic Control of Armed Forces in Postcommunist Europe". In Democratic Control of the Military in Postcommunist Europe. Guarding the Guards., szerk. Andrew Cottey et al., 1-17. Basingstoke; New York: Palgrave Macmillan.

. 2002b. „Soldiers, Politics and Defence in Postcommunist Europe”. In Democratic Control of the Military in Postcommunist Europe. Guarding the Guards., szerk. Andrew Cottey et al., 251-63. Basingstoke; New York: Palgrave Macmillan. . 2002c. „The Second Generation Problematic: Rethinking Democracy and Civil-Military Relations". Armed Forces \& Society 29 (1): 31-56. https://doi.org/10.1177/0095327x0202900103. . 2005. „Civil-Military Relations in Postcommunist Europe: Assessing the Transition". European Security 14 (1): 1-16. https://doi.org/10.1080/09662830500042452.

Cular, Goran. 2000. „Political Development in Croatia 1990-2000: Fast Transition Postponed Consolidation". Politicka Misao 37 (5): 30-46.

Cumpek, Tatjana. 2003. „Transparency and Accountability in the Defence and Security Sectors". In Defence and Security Sector Governance and Reform in South East Europe: Insights and Perspectives. Croatia: A Self-Assessment Report, szerk. Philipp H. Fluri és Jan Trapans, 112-25, Geneva: DCAF 
Foundation.

Cvrtila, Vladko. 2003. „The Parliament and Security Sector”. In Defence and Security Sector Governance and Reform in South East Europe: Insights and Perspectives. Croatia: A Self-Assessment Report, szerk. Philipp H. Fluri és Jan Trapans, 36-52. Geneva: DCAF Foundation.

Cziráky, Dario. 2003. „International Requirements and Influence”. In Defence and Security Sector Governance and Reform in South East Europe: Insights and Perspectives. Croatia: A Self-Assessment Report, szerk. Philipp H. Fluri és Jan Trapans, 139-62. DCAF Foundation: Geneva.

Danopoulos, Constantine P. 1995. „Post-Totalitarian Civil-Military Relations”. Balkan Forum 3 (3): 157-71.

Danopoulos, Constantine P., és Daniel Zirker. 1999. The military and society in the former Eastern Bloc. Boulder (Colo.): Westview Press.

Dean, Robert W. 1982. „The Yugoslav Army”. In Communist Armies in Politics, szerk. Jonathan R. Adelman, 83-101. Boulder (Colo.): Westview Press.

Defense Industry Daily. 2014. „Slovenian Army's New APCs: Patria’s AMVs”. Defense Industry Daily. 2014. február 9.

http://www.defenseindustrydaily.com/slovenian-armys-new-apcs-patriasamvs-updated-02358/. Letöltve: 2017.07.05.

Desch, Michael C. 1996. „Threat environments and military missions”. In Civilmilitary relations and democracy, szerk. Larry Diamond és Marc F. Plattner, 12-29. Baltimore; London: Johns Hopkins University Press.

. 1998. „Soldiers, States and Structures: The End of Cold War and Weakening U.S. Civilian Control”. Armed Forces \& Society 24 (3): 389-406. https://doi.org/10.1177/0095327x9802400304. . 1999. Civilian Control of the Military, The Changing Security Environment. Baltimore: Johns Hopkins University Press.

Dolenec, Danijela. 2013. Democratic institutions and authoritarian rule in Southeast Europe. Colchester: ECPR Press.

Domjancic, Stjepan. 2015. Civilno-vojni odnosi i tranzicija. Zagreb: Despot Infinitus.

Donnelly, Chris. 1996. „Developing a National Strategy for the Transformation of the Defence Establishment in Post-Communist States". European Security 5 (1): 1-16. https://doi.org/10.1080/09662839608407250.

Dujmovic, Krsevan Antun. 2008. „Public opinion and media role in the process of meeting NATO membership criteria - the case of Croatia". In Western Balkans after the Bucharest Summit: Key challenges and the way ahead, szerk. Lidija Cehulic-Vukadinovic és Dana Lusa, 74-79.

Zagreb: Atlantic Council of Croatia.

Economist Intelligence Unit. 1998a. „Country Report: Croatia. 3rd quarter 1998.” London: Economist Intelligence Unit. . 1998b. „Country Report: Croatia. 4rd quarter 1998.” London: Economist Intelligence Unit. . 1999. „Country Report: Croatia. 2rd quarter 1999.” London: Economist Intelligence Unit. . 2008. „Country Report: Croatia. November 2008”. London: Economist Intelligence Unit. . 2009a. „Country Report: Croatia. July 2009”. London: Economist Intelligence Unit. 
2009b. „Country Report: Croatia. March 2009”. London: Economist Intelligence Unit.

. 2011. „Country Report: Croatia. January 2011”. London: Economist Intelligence Unit.

Edmunds, Timothy. 2003. „Defense Reform in Croatia and Serbia-Montenegro”. Adelphi Papers 43 (360).

- 2003b. „Political conditionality and security-sector reform in postcommunist Europe". Conflict, Security and Development 3 (1): 139-44. . 2006. „What are Armed Forces For? The Changing Nature of Military Roles in Europe". International Affairs 82 (6): 1059-75. https://doi.org/10.1111/j.1468-2346.2006.00588.x. 2007. Security Sector Reform in Transforming Societies: Croatia, Serbia and Montenegro. Manchester: Manchester University Press. . 2013. „Security sector reform”. In The Routledge Handbook of CivilMilitary Relations, szerk. Thomas C. Bruneau és Florina C. Matei, 48-60. New York: Routledge.

Edmunds, Timothy, Anthony Forster, és Andrew Cottey. 2003. „Conclusion: Patterns and Trends in Military-Society Relations in Postcommunist Europe". In Soldiers and Societies in Post-Communist Europe: Legitimacy and Change, szerk. Anthony Forster, Timothy Edmunds, és Andrew Cottey, 237-57. London: Palgrave Macmillan.

Ekwall-Uebelhart, Barbara, és Andrei Raevsky. 1996. Managing Arms in Peace Processes: Croatia and Bosnia-Herzegovina. Geneva; New York: United Nations Institute for Disarmament Research.

Epstein, Rachel A. 2005. „NATO Enlargement and the Spread of Democracy: Evidence and Expectations". Security Studies 14 (1): 63-105. https://doi.org/10.1080/09636410591002509.

Feaver, Peter D. 1996. „The Civil-Military Problematique: Huntington, Janowitz and the Question of Civilian Control". Armed Forces \& Society 23 (2): 149-78. https://doi.org/10.1177/0095327x9602300203. . 1998. „The Crisis as Shirking: An Agency Theory explanation of the souring of American civil-military relations". Armed Forces \& Society 24 (3): 40734. https://doi.org/10.1177/0095327x9802400305. . 1999. „Civil-Military Relations”. Annual Review of Political Science 2: 211-41. https://doi.org/10.1146/annurev.polisci.2.1.211. . 2003. Armed Servants: Agency, Oversight, and Civil-Military Relations. Cambridge, Mass.; London: Harvard University Press. 2006. „A civil-katonai ellentét: Huntington, Janowitz és a civil kontroll kérdése”. In Civil-katonai kapcsolatok: a tudomány határán: válogatás a hidegháború utáni szakirodalomból, szerk. Molnár Ferenc, 77-109. Budapest: Zrínyi.

Finer, Samuel. 1976. The man on horseback: the role of the military in politics. Baltimore: Penguin Books.

Freedom House. 2010. „Nations in Transit 2010: Croatia”. https://freedomhouse.org/report/nations-transit/2010/croatia. Letöltve: 2018.03.24.

Gareljic, Zlatko. 2006. „Croatia and NATO”. In Yearbook Sipan 2006, szerk. Lidija Cehulic-Vukadinovic, 115-24. Zagreb: Politicka Kultura. 
2007. „Elections, Political Parties, Defence and Armed Forces”. In Yearbook Sipan 2007, szerk. Lidija Cehulic-Vukadinovic, 102-10. Zagreb: Politicka Kultura.

George, Alexander L., és Andrew Bennett. 2005. Case Studies and Theory Development in the Social Sciences. London; Cambridge, Mass.: MIT Press.

Gersak, Teodor. 1995. „Slovenia and the international security organisations”. In Slovenija in NATO: zbornik = Slovenia and NATO: anthology, szerk. Igor Kotnik, 64-69. Ljubljana: Atlantski Svet Slovenije.

Gheciu, Alexandra. 2005a. NATO in the „New Europe”: The Politics of International Socialization after the Cold War. Stanford, CA: Stanford University Press. . 2005b. „Security Institutions as Agents of Socialization? NATO and the »New Europe«". International Organization 59 (4): 973-1012. https://doi.org/10.1017/s0020818305050332.

Government of the Republic of Slovenia. 2010. Strategy of the Participation of the Republic of Slovenia in International Operations and Missions. Ljubljana: Government of the Republic of Slovenia.

Gow, James. 1991. „Deconstructing Yugoslavia”. Survival 33 (4): 291-311. https://doi.org/10.1080/00396339108442599. 1992. Legitimacy and the military: the Yugoslav crisis. London: Pinter.

Gow, James, és Cathie Carmichael. 2000. Slovenia and the Slovenes: A Small State and the New Europe. London: Hurst \& Company.

Grayston, Neil. 2001. „Democratic Control of the Armed Forces of Slovenia - A Progress Report”. Sandhurst: Conflict Studies Research Centre, Royal Military Academy.

Grdešić, Ivan. 2004. „US-Adriatic Charter of Partnership: Securing the NATO Open Door Policy". Politicka Misao 41 (5): 104-22.

Grizold, Anton, szerk. 1991. Demilitarizacija Slovenije in nacionalna varnost. Ljubljana: Znanstveno in publicistično središče.

. 1994. „The National Security Issue in Slovenia”. In Small states compared: Politics of Norway and Slovenia, szerk. Bojko Bucar és Stein Kuhnle, 80-93. Bergen: Alma Mater.

. 1997. „The Defense of Slovenia”. In Making a New Nation: The Formation of Slovenia, szerk. Danica Fink-Hafner és John R. Robbins, 46-55. Aldershot: Darthmouth.

1997b. „Civil-Military relations in Slovenia”. In Civil-military relations in post-communist states: Central and Eastern Europe in transition, szerk. Anton Bebler, 101-9. Westport, CT; London: Praeger.

1997c. „Slovenia and NATO: Between great expectations and slight doubts". In Central-Eastern Europe and Euro-Atlantic security: proceedings of the international conference / International Conference Central-Eastern Europe and Euro-Atlantic Security, Ljubljana - Bled, Slovenia, April 24 - 26, 1997, szerk. Anton Bebler, 91-101. Ljubljana: Defense Studies Center, University of Ljubljana.

. 2014. Interjú: Anton Grizold egyetemi tanár, volt szlovén védelmi miniszter (2000-2004). Ljubljana, 2014. március 4.

Grizold, Anton, és Iztok Prezelj. 2000. „Public opinion and the national security of Slovenia”. In International security, mass media and public opinion, szerk. Marjan Malesic, 149-65. Ljubljana: Faculty of Social Sciences, University of Ljubljana. 
Grizold, Anton, és Vinko Vegic. 2001. „Small states and alliances: The Case of Slovenia”. In Small states and alliances, szerk. Erich Reiter és Heinz Gartner, 145-59. Heidelberg: Physica Verlag.

Grubisa, Damir. 2003. „Democratic Control of Armed Forces”. In Defence and Security Sector Governance and Reform in South East Europe: Insights and Perspectives. Croatia: A Self-Assessment Report, szerk. Philipp H. Fluri és Jan Trapans, 19-35. DCAF Foundation: Geneva.

Harangozó, Dániel. 2012. „A Szlovén Hadsereg harckocsitendere és a Patria-ügy. Közpolitikai elemzés.” Budapest: BCE Politikatudományi Doktori Iskola. Kézirat. . 2015. „Civil-katonai kapcsolatok a titói Jugoszláviában (1945-1991)”. In Tavaszi Szél 2015 konferenciakötet, 591-607. Budapest; Eger: Doktoranduszok Országos Szövetsége - Líceum Kiadó.

Hendrickson, Ryan C. 2002. „Expanding NATO: The Case for Slovenia”. Parameters 32 (3): 64-76.

Hendrickson, Ryan C., és Thomas Ethridge. 2004. „Slovenia and NATO Membership: Testing the criticisms of alliance expansion". Baltic Defense Review 2 (12): 113-27.

Hendrickson, Ryan C., és Michael Rudy. 2003. „Transforming Slovenia’s military: Moving toward NATO membership". Journal of Slavic Military Studies 16 (4): 46-57. https://doi.org/10.1080/13518040308430581.

Hendrickson, Ryan C., és Ryan P. Smith. 2006. „Croatia and NATO: Moving Toward Alliance Membership". Comparative Strategy 25 (4): 297-306. https://doi.org/10.1080/01495930601028630.

Herspring, Dale R. 1992. „Civil-Military Relations in Post-Communist Eastern Europe: The Potential For Praetorianism". Studies in Comparative Communism 25 (2): 99-122. https://doi.org/10.1016/0039-3592(92)90001-z. . 1999. „Samuel Huntington and Communist Civil-Military Relations”. Armed Forces \& Society 25 (4): 557-77. https://doi.org/10.1177/0095327x9902500403.

Hockenos, Paul. 2003. Homeland Calling: Exile Patriotism and the Balkan Wars. Ithaca; London: Cornell University Press.

Horncastle, James. 2013. „Reaping the Whirlwind: Total National Defense's Role in Slovenia's Bid for Secession". Journal of Slavic Military Studies 26 (3): 528-50. https://doi.org/10.1080/13518046.2013.813296

Horowitz, Shale. 2005. From ethnic conflict to stillborn reform: The former Soviet Union and Yugoslavia. College Station: Texas A\&M University Press.

Hrvatski Sabor. 2007. „Odluka o nepozivanju novaka na obvezu služenja vojnog roka". Narodne Novine 2007 (105): 3065.

Huntington, Samuel. 1957. The Soldier and the State. Cambridge, Mass.: The Bellknap Press / Harvard University Press. . 1991. The third wave: democratization in the late twentieth century. Norman; London: Oklahoma University Press. . 1994. A katona és az állam: a civil és a katonai szféra viszonyának elmélete és politikája. Budapest: Zrínyi.

IMO. 2011. Context Analysis of the Security Sector Reform in Croatia 1989 - 2009. Zagreb: Institut za medunarodne odnose. 
International Crisis Group. 1998. „Change in the offing: the shifting political scene in Croatia.” ICG Balkans Report N50. Zagreb / Sarajevo: International Crisis Group.

Ivankovic, Zeljko, és Dunja Melcic. 2007. „Der bosniakisch-kroatische »Krieg im Kriege «". In Der Jugoslawien-Krieg: Handbuch zu Vorgeschichte, Verlauf und Konsequenzen, szerk. Dunja Melcic, 415-38. Wiesbaden: VS Verlag für Sozialwissenschaften.

Jakesevic, Ruzica, Dario Malnar, és Sinisa Tatalovic. 2017. „Croatian Policy towards the NATO Enlargement to the Western Balkans". Security Dialogues (Skopje) 8 (1-2): 577-94.

Jane's Defense Weekly. 2006a. „Eurosatory 2006: Patria AMV wins battle for Slovenian contract". Jane's Defense Weekly, 2006. június 13. . 2006b. „Slovenia orders Patria AMVs, Jane's Defence Weekly”. Jane’s Defense Weekly, 2006. december 21.

- 2007. „Slovenia takes delivery of first AMV”. Jane’s Defense Weekly, 2007. december 24.

- 2009. „Slovenia finally receives delayed Patria AMVs”. Jane’s Defense Weekly, 2009. június 23.

_.2010. „Slovenia plans to cut order for AMVs”. Jane's Defense Weekly, 2010. július 28 .

—.2011. „Slovenia assesses AMV options”. Jane’s Defense Weekly, 2011. április 1 .

Janowitz, Morris. 1960. The professional soldier, a social and political portrait. New York: Free Press.

- 1971. The professional soldier, a social and political portrait. New York: Free Press.

Jansa, Janez. 1994. The Making of the Slovenian State 1988-1992: The Collapse of Yugoslavia. Ljubljana: Mladinska Knjiga.

Jazbec, Milan. 2003. „Establishment and Reforms of the Slovenian Defence System”. In Security Sector Governance in the Western Balkans, szerk. Istvan Gyarmati és Scott Vesel, 189-95. Baden-Baden: Nomos Verlag.

_. 2014. „Slovenia and NATO: a long and winding road”. Sodobni vojaski izzivi 16 (3): 29-44.

Jelusic, Ljubica. 2003. „Defense Reforms in Slovenia, 1991-2001”. In Security and cooperation in Southeast Europe, szerk. Anton Grizold, 109-31. Ljubljana: Faculty of Social Sciences, University of Ljubljana.

—. 2005. „Domestic Military Assistance: The Case of Slovenia”. In Defence Transformation in Europe: evolving military roles, szerk. Timothy Edmunds és Marjan Malesic, 83-90. Amsterdam: IOS Press.

— 2014. Interjú: Ljubica Jelusic egyetemi tanár, volt szlovén védelmi miniszter (2008-2011). Ljubljana, 2014. március 5.

— 2017. Interjú: Ljubica Jelusic egyetemi tanár, volt szlovén védelmi miniszter miniszterrel (2008-2011). Ljubljana, 2017. október 23.

Jelusic, Ljubica, és Marjan Malesic. 2003. „La Petite Muette’ and Suspicious Controller: Armed Forces and Society in Slovenia". In Soldiers and Societies in Post-Communist Europe: Legitimacy and Change, szerk. Anthony Forster, Timothy Edmunds, és Andrew Cottey, 169-84. London: Palgrave Macmillan. Johnson, A. Ross. 1971. „Total National Defense in Yugoslavia”. Report No. P-4746. Santa Monica: The Rand Corporation. 
1982. „The role of the military in Yugoslavia: a historical sketch”. In Soldiers, peasants, and bureaucrats: civil-military relations in Communist and modernizing societies, szerk. Roman Kolkowicz és Andrzej Korbonski, 181-98. London: Allen \& Unwin.

Joó, Rudolf, és Martinusz Zoltán. 1998. „A haderő demokratikus kontrollja: a »miért« és »hogyan « néhány kérdése”. Budapest: Magyar Atlanti Tanács.

Joó, Rudolf, és Pataki G. Zsolt, szerk. 1998. A haderő demokratikus irányítása. Budapest: Zrínyi.

Juhász, József. 1996. A délszláv háborúk rövid története (1991-1995). Budapest: Stratégiai és Védelmi Kutatóintézet. . 1999. Volt egyszer egy Jugoszlávia. A délszláv állam története. Budapest: AULA Kiadó.

Keohane, Robert O. 1969. „'Lilliputians’ dilemmas: small states in international politics". International Organization 23 (2): 291-310. https://doi.org/10.1017/s002081830003160x.

Keridis, Dimitris, és Charles M. Perry, szerk. 2004. Defense reform, modernization, \& military cooperation in Southeastern Europe. Dulles, VA: Brassey's.

Kladnik, Tomaz, szerk. 2011. Vojaska obramba Slovenije. Ljubljana: Defensor.

Knezovic, Sandro, és Zvonimir Mahečić. 2012. „Chapter 3 - Croatia”. In Almanac on Security Sector Oversight in the Western Balkans: 2012, szerk. Miroslav Hadzic, 73-100. Geneva; Belgrade: DCAF Foundation - Belgrade Center for Security Policy.

Kolkowicz, Roman. 1978. „Interest groups in Soviet politics: the case of the military". In Civil-military relations in Communist systems, szerk. Dale R. Herspring és Ivan Volgyes, 9-25. Boulder (Colo.): Westview Press. . 1982a. „Military intervention in the Soviet Union: Scenario for posthegemonial synthesis". In Soldiers, peasants, and bureaucrats: civil-military relations in Communist and modernizing societies, szerk. Roman Kolkowicz és Andrzej Korbonski, 109-38. London: Allen \& Unwin. . 1982b. „Toward a theory of civil-military relations in communist hegemonial systems". In Soldiers, peasants, and bureaucrats: civil-military relations in Communist and modernizing societies, szerk. Roman Kolkowicz és Andrzej Korbonski, 231-51. London: Allen \& Unwin.

Kopac, Erik. 2012. „Efficient delivery of national military capabilities: the case of Slovene Armed Forces”. Sovremena makedonska odbrana 12 (23): 89-100. 2017. Interjú: Erik Kopac biztonság- és védelempolitikai szakértő, Miro Cerar szlovén miniszterelnök biztonságpolitikai tanácsadója. Ljubljana, 2017. október 26.

Kotnik, Igor. 2003. „Does Successful Reform of the Slovenian Armed Forces Depend on its Professionalization?" In Conscription vs. all-volunteer forces in Europe, szerk. Marjan Malesic, 187-201. Baden-Baden: Nomos Verlag.

Kotnik, Igor, és Erik Kopac. 2002. „Professionalization of Slovenian Armed Forces”. In The Challenge of Military Reform in Post-Communist Europe: Building Professional Armed Forces, szerk. Anthony Forster, Timothy Edmunds, és Andrew Cottey, 149-63. London: Palgrave Macmillan.

Krajnc, Zoltán. 2009. „Szlovénia: Egy volt jugoszláv tagköztársaság gyakorlatának adaptálása a a NATO doktrinális kultúrájába". Repüléstudományi Közlemények 21 (4).

http://www.repulestudomany.hu/folyoirat/2009_4/2009_4_Krajnc_Zoltan.html Letöltve: 2017.07.05. 
Krasner, Steven D., szerk. 1983. International Regimes. Ithaca; New York: Cornell University Press.

Lasswell, Harold. 1941. „The Garrison State”. American Journal of Sociology 46 (4): 455-68. https://doi.org/10.1086/218693.

Liebl, Richard B., Marin Braovac, és Andriana Jelic. 2002. „Security Assistance Programs: The Catalyst for Transition in the Croatian Military".

The DISAM Journal, Spring 2002: 5-9.

http://www.disam.dsca.mil/Pubs/Indexes/v.24_3/Jelic,\%20Andrijana,\%20Cat alyst.pdf. Letöltve: 2018.03.24.

Lijphart, Arend. 1971. „Comparative Politics and the Comparative Method”. American Political Science Review 65 (3): 682-93. https://doi.org/10.2307/1955513.

Longo, Matthew. 2006. „The HDZ's Embattled Mandate: Divergent Leadership, Divided Electorate, 2003-2006". Problems of Post-Communism 53 (3): 36-43. https://doi.org/10.2753/ppc1075-8216530303.

Lukic, Reneo. 2008. „Civil-Military Relations in Croatia (1990-2005)”. In Croatia since independence: war, politics, society, foreign relations, szerk. Sabrina Petra Ramet, Reneo Lukic, és Konrad Clewing, 189-210. München: Oldenbourg.

Lukic, Reneo, és Jean-Francois Morel. 2002. „Les relations civilo-militaires en Croatie, 1990-2001". Questions de Recherche No. 5. Paris: Centre d'études et de recherches internationales Sciences Po.

Mahečić, Zvonimir. 2003a. „Capacity Building and Good Governance in Security and Defence Reform". In Defence and Security Sector Governance and Reform in South East Europe: Insights and Perspectives. Croatia: A Self-Assessment Report, szerk. Philipp H. Fluri és Jan Trapans, 93-111. Geneva: DCAF Foundation. . 2003b. „Civilians and the Military in Security Sector Reform”. In Defence and Security Sector Governance and Reform in South East Europe: Insights and Perspectives. Croatia: A Self-Assessment Report, szerk. Philipp H. Fluri és Jan Trapans, 36-52. Geneva: DCAF Foundation. - 2003c. „Peacekeeping and Regional Security”. In Defence and Security Sector Governance and Reform in South East Europe: Insights and Perspectives. Croatia: a Self-Assessment Report, szerk. Philipp H. Fluri és Jan Trapans, 163-74. Geneva: DCAF Foundation. 2009. „The Interaction between Security Politics and Science in Croatia”. Western Balkans Security Observer, 4 (12): 26-37.

Malesic, Marjan. 2003. „A Conscript Army or an All-Volunteer Force? A Contribution to the Discussion in Slovenia". In Conscription vs. all-volunteer forces in Europe, szerk. Marjan Malesic, 173-86.

Baden-Baden: Nomos Verlag. . 2006. „Executive decisions and divisions: disputing competences in civilmilitary relations in Slovenia". In Civil-Military Relations in Europe: Learning from Crisis and Institutional Change, szerk. Hans Born, Marina Caparini, és Jurgen Kuhlmann, 130-46. Abingdon: Routledge. 2017. Interjú: Marjan Malesic egyetemi tanár. Ljubljana, 2017. október 24.

Malesic, Marjan, és Ljubica Jelusic. 2005. „Towards Civilian Supremacy: CivilMilitary Relations in Slovenia". In The Evolution of Civil-Military Relations in Southeast Europe, szerk. Philipp H. Fluri, Gustav Gustenau, és Plamen Pantev, 211-29. Heidelberg: Physica Verlag. 
Marjan Malesic et al. 2015. Small, but Smart? : the structural and functional professionalization of the Slovenian Armed Forces.

Baden-Baden: Nomos Verlag.

Matei, Florina C. 2013. „A new conceptualization of civil-military relations”. In The Routledge Handbook of Civil-Military Relations, szerk. Thomas C. Bruneau és Florina C. Matei, 26-38. New York: Routledge.

Meier, Viktor. 1999. Yugoslavia: a history of its demise. London; New York: Routledge.

Melcic, Dunja. 2008. „Croatia's Discourse about the Past and Some Problems of Croatian-Bosnian Understanding". In Croatia since independence: war, politics, society, foreign relations, szerk. Sabrina Petra Ramet, Reneo Lukic, és Konrad Clewing, 107-39. München: Oldenbourg.

Melnykovska, Inna, és Rainer Schweickert. 2010. „Regional Security as a Driver of Institutional Change in post-Communist Countries? Empirical Evidence on NATO Accession Incentives".

Kieler Analysen zur Sicherheitspolitik No. 26. Kiel.

Mihaljevic, Branko. 2012. Novi pristupi istraživanjima civilno-vojnih odnosa: primjeri Republike Hrvatske i Republike Srbije. Doktori értekezés. Zagreb: Sveučilište u Zagrebu, Fakultet političkih znanosti.

Mikulic, Albin. 2006. Defending Democratic Slovenia - 1991. Ljubljana: Republic of Slovenia Ministry of Defense. . 2007. Rebels with a cause. The National Defense Manoeuvre Structure. Ljubljana: Republic of Slovenia Ministry of Defense.

Military Doctrine. 2006. Military Doctrine. Ljubljana: Slovenian Armed Forces, Doctrine, Development, Education and Training Command.

Milivojevic, Marko. 1988. „The political role of the Yugoslav People's Army in contemporary Yugoslavia”. In Yugoslavia's security dilemmas: armed forces, national defence, and foreign policy, szerk. Milivojevic Milivojevic, John B. Allcock, és Pierre Maurer, 15-59. Oxford / Oxfordshire: Berg. .1992. „The role of the Yugoslav intelligence and security community”. In Yugoslavia in transition: choices and constraints, szerk. Marko Milivojevic, John B. Allcock, és J. Horton, 199-237. New York: St. Martin's Press.

Ministarstvo obrane RH. 2003. Studija o profesionalizaciji Hrvatske Vojske. Zagreb: Ministarstvo obrane Republike Hrvatske. . 2008. Godišnje izvješće o spremnosti obrambenog sustava, provođenju kadrovske politike i ukupnom stanju u oružanim snagama Republike Hrvatske za 2007. godinu. Zagreb: Ministarstvo obrane Republike Hrvatske. . 2009. Godišnje izvješće o spremnosti obrambenog sustava, provođenju kadrovske politike i ukupnom stanju u oružanim snagama Republike Hrvatske za 2008. godinu. Zagreb: Ministarstvo obrane Republike Hrvatske. . 2010. Godišnje izvješće o spremnosti obrambenog sustava, provođenju kadrovske politike i ukupnom stanju u oružanim snagama Republike Hrvatske za 2009. godinu. Zagreb: Ministarstvo obrane Republike Hrvatske. . 2011. Godišnje izvješće o spremnosti obrambenog sustava, provođenju kadrovske politike i ukupnom stanju u oružanim snagama Republike Hrvatske za 2010. godinu. Zagreb: Ministarstvo obrane Republike Hrvatske. . 2012. Godišnje izvješće o spremnosti obrambenog sustava, provođenju kadrovske politike i ukupnom stanju u oružanim snagama Republike Hrvatske za 2011. godinu. Zagreb: Ministarstvo obrane Republike Hrvatske. 
2016. 25 godina oruzanih snaga Republike Hrvastke / 25 years of the

Croatian Armed Forces. Zagreb: Ministarstvo obrane Republike Hrvatske.

Ministrstvo za obrambo RS. 1995. „Navodilo o izvrševanju obveznosti do predsednika republike na obrambnem področju". Uradni List Republike Slovenije 1995 (64): 4974. . 2017a. Letno porocilo Minstrstva za Obrambo za leto 2016. Ljubljana: Ministrstvo za obrambo Republike Slovenije. . 2017b. „Nekdanji ministri za obrambo”. Ministrstvo za obrambo RS. 2017. http://www.mo.gov.si/si/o_ministrstvu/nekdanji_ministri_za_obrambo/ Letöltve: 2017.07.02.

Montgomery, William T. 1998. „Croatia’s roadmap to Partnership for Peace”. Croatian International Relations Review 4 (11): 87-91.

NATO. 1995. Study on NATO Enlargement. https://www.nato.int/cps/en/natohq/official_texts_24733.htm? Letöltve: 2018.04.08.

- 2013. Allied Joint Doctrine for Civil-Military Cooperation. AJP-3.4.9. https://www.cimic-coe.org/wp-content/uploads/2014/06/AJP-3.4.9-EDA-V1E1.pdf. Letöltve: 2018.04.08.

NATO Review. 2000. „Interview: Ivica Racan: Making up for lost time”. NATO Review, 2000, No. 2. https://www.nato.int/docu/review/2000/Buildingstability-Balkans/Making-up-for-lost-time/EN/index.htm Letöltve: 2018.03.22.

Nelson, Daniel N. 2002a. „Armies, security and democracy in Southeast Europe”. Armed Forces \& Society 28 (3): 427-54. https://doi.org/10.1177/0095327x0202800305. 2002b. „Definition, diagnosis, therapy: A civil-military critique”. Defense and Security Analysis 18 (2): 157-70. https://doi.org/10.1080/14751790220132565.

Nordlinger, Eric. 1977. Soldiers in Politics: Military Coups and Governments. New Jersey: Prentice Hall.

Odom, William E. 1978. „The Party-military connection: a critique”. In Civilmilitary relations in Communist systems, szerk. Dale R. Herspring és Ivan Volgyes, 27-52. Boulder (Colo.): Westview Press. 1998. The collapse of the Soviet military. New Haven; London: Yale University Press.

Olmeda, José. 2013. „Civil-military relations and comparative politics”. In The Routledge Handbook of Civil-Military Relations, szerk. Thomas C. Bruneau és Florina C. Matei, 61-76. New York: Routledge.

Pavlakovic, Vjeran. 2008. „Better the Grave than a Slave: Croatia and the International Criminal Tribunal for the Former Yugoslavia”. In Croatia since independence: war, politics, society, foreign relations, szerk. Sabrina Petra Ramet, Reneo Lukic, és Konrad Clewing, 447-77. München: Oldenbourg.

Perlmutter, Amos, és William M. LeoGrande. 1982. „The Party in Uniform: Toward a Theory of Civil-Military Relations in Communist Political Systems". American Political Science Review 76 (4): 778-89. https://doi.org/10.2307/1962970.

Pickering, Paula M., és Mark Baskin. 2008. „What is to be done? Succession from the League of Communists of Croatia". Communist and Post-Communist Studies 41 (4): 521-40. https://doi.org/10.1016/j.postcomstud.2008.09.001. 
Pietz, Tobias, és Marc Remillard. 2006. Defense Reform and Conversion in Albania, Macedonia and Croatia. BICC Briefs No. 34. Bonn: Bonn International Center for Conversion.

Polak, Nathan M., Ryan C. Hendrickson, és Nathan G. D. Garrett. 2009. „NATO Membership for Albania and Croatia: Military Modernization, Geo-Strategic Opportunities and Force Projection". Journal of Slavic Military Studies 22 (4): 502-14. https://doi.org/10.1080/13518040903355745.

Radicevic, Tomo. 2003. „The New Security Strategy: International Cooperation, Crisis Management and National Defence". In Defence and Security Sector Governance and Reform in South East Europe: Insights and Perspectives. Croatia: A Self-Assessment Report, szerk. Philipp H. Fluri és Jan Trapans, 175-89. Geneva: DCAF Foundation.

Radio Free Europe / Radio Liberty. 2009. „Croatia Indicts Former Defense Minister For Corruption”. Radio Free Europe / Radio Liberty. 2009. október 28. https://www.rferl.org/a/Croatia_Indicts_Former_Defense_Minister_For_Corr uption/1863553.html. Letöltve: 2018.03.26.

Ramet, Sabrina Petra 1992. Nationalism and federalism in Yugoslavia, 1962-1991. Bloomington: Indiana University Press. . 2010. „Politics in Croatia since 1990”. In Central and southeast European politics since 1989, szerk. Sabrina P. Ramet, 258-86. Cambridge; New York: Cambridge University Press.

Razsa, Maple, és Nicole Lindstrom. 2004. „Balkan Is Beautiful: Balkanism in the Political Discourse of Tudman's Croatia”. East European Politics \& Societies 18 (4): 628-50. https://doi.org/10.1177/0888325404266939.

Remington, Robin Alison. 1978a. „Civil-Military Relations in Yugoslavia: The Partisan Vanguard". Studies in Comparative Communism 11 (3): 250-64. https://doi.org/10.1016/0039-3592(78)90020-0. . 1978b. ,The military as an interest group in Yugoslav politics”. In Civilmilitary relations in Communist systems, szerk. Dale R. Herspring és Ivan Volgyes, 181-99. Boulder (Colo.): Westview Press. . 1985. „Political-Military Relations in Post-Tito Yugoslavia”. In Yugoslavia in the 1980s, szerk. Pedro Ramet, 56-75. Boulder (Colo.): Westview Press. . 1996. „The Yugoslav Army: Trauma and Transition”. In Civil-Military Relations in the Soviet and Yugoslav Successor States, szerk. Constantine P. Danopoulos és Daniel Zirker, 153-73. Boulder (Colo.): Westview Press. . 1997. „State Cohesion and the Military”. In State-Society Relations in Yugoslavia, 1945-1992, szerk. Melissa K. Bokovoy et al., 61-78. New York: St. Martin's Press.

„Resolution on the long-term development and equipping programme of the Slovenian Armed Forces up to 2025 (ReSDPRO SV 2025)”. 2010. Uradni List Republike Slovenije 2010 (99): 15483.

„Resolution on the National Security Strategy of the Republic of Slovenia (ReSNV2001)". 2001. Uradni List Republike Slovenije 2001 (56): 5738.

Reuters. 1993. „Arms scandal reminds Slovenes war is still close to home”. Reuters, 1993. október 12. . 2012. „Slovenia ends controversial Finnish arms deal”. Reuters. 2012. szeptember 5. http://www.reuters.com/article/slovenia-patriaidUSL6E8K5A4B20120905. Letöltve: 2017.07.05. 
2015. „Slovenian bribery trial against ex-PM Jansa expires”. Reuters. 2015. szeptember 7. http://www.reuters.com/article/us-slovenia-corruptionidUSKCN0R71KC20150907. Letöltve: 2017.07.05.

RFE/RL Newsline. 1998. „Slovenian defense minister asked to quit”. RFE/RL Newsline. 1998. október 15. http://www.hri.org/news/balkans/rferl/1998/9810-15.rferl.html\#15. Letöltve: 2017.07.01.

Rickli, Jean-Marc. 2008. „European small states’ military policies after the Cold War: from territorial to niche strategies". Cambridge Review of International Affairs 21 (3): 307-25. https://doi.org/10.1080/09557570802253435.

Roberts, Adam. 1986. Nations in arms: the theory and practice of territorial defence. New York: St. Martin's Press.

Roberts, Walter R. 1987. Tito, Mihailović, and the Allies, 1941-1945. Durham: Duke University Press.

RoC (Republic of Croatia) Ministry of Defence. 2005a. Annual Exchange of Information on Defence Planning: 2005. Zagreb: Republic of Croatia Ministry of Defence.

2005b. Strategic Defence Review. Zagreb: Republic of Croatia Ministry of Defence.

. 2006a. Annual Exchange of Information on Defence Planning: 2006.

Zagreb: Republic of Croatia Ministry of Defence.

. 2006b. The Croatian Armed Forces Long-Term Development Plan, 2006-

2015. Zagreb: Republic of Croatia Ministry of Defence. . 2007. Annual Exchange of Information on Defence Planning: 2007. Zagreb: Republic of Croatia Ministry of Defence.

. 2008. Annual Exchange of Information on Defence Planning: 2008. Zagreb: Republic of Croatia Ministry of Defence.

2009. Annual Exchange of Information on Defence Planning: 2009. Zagreb: Republic of Croatia Ministry of Defence.

. 2013. Strategic Defence Review. Zagreb: Republic of Croatia Ministry of Defence.

RS (Republic of Slovenia) Ministry of Defense. 2001. Work guideline of the Ministry of Defense up to 2004. Ljubljana: Republic of Slovenia Ministry of Defense. .2004a. Annual Report of the Ministry of Defence for 2003. Ljubljana: Republic of Slovenia Ministry of Defense.

2004b. Strategic Defense Review. Ljubljana: Republic of Slovenia Ministry of Defense.

2005. Annual Report of the Ministry of Defence for 2004. Ljubljana:

Republic of Slovenia Ministry of Defense.

. 2006. Annual Report of the Ministry of Defence for 2005. Ljubljana:

Republic of Slovenia Ministry of Defense.

. 2008. Annual Report of the Ministry of Defence for 2007. Ljubljana:

Republic of Slovenia Ministry of Defense.

. 2009a. Annual Report of the Ministry of Defence for 2008. Ljubljana:

Republic of Slovenia Ministry of Defense.

. 2009b. Defense Sector Strategic Review. Ljubljana: Republic of Slovenia

Ministry of Defense.

2010. Annual Report of the Ministry of Defence for 2009. Ljubljana:

Republic of Slovenia Ministry of Defense.

. 2011. Annual Report of the Ministry of Defence for 2010. Ljubljana:

Republic of Slovenia Ministry of Defense. 
2012. Annual Report of the Ministry of Defence for 2011. Ljubljana:

Republic of Slovenia Ministry of Defense.

. 2013. Annual Report of the Ministry of Defence for 2012. Ljubljana:

Republic of Slovenia Ministry of Defense.

RTV Slovenija. 2006a. „Za patrio pripravljen odstopiti”. RTV Slovenija. 2006. június 27. http://www.rtvslo.si/slovenija/za-patrio-pripravljen-odstopiti/56257.

Letöltve: 2017.07.05

. 2006b. „Izbira Patrie najbrž najboljša”. RTV Slovenija. 2006. július 6. http://www.rtvslo.si/slovenija/izbira-patrie-najbrz-najboljsa/56693.

Letöltve: 2017.07.05

. 2006c. „Pogodba o oklepnikih pod streho”. RTV Slovenija. 2006. december

19. http://www.rtvslo.si/slovenija/pogodba-o-oklepnikih-pod-streho/64547.

Letöltve: 2017.07.05

. 2007a. „Erjavec priznal, da so gole patrie resničnost”. RTV Slovenija. 2007.

január 21. http://www.rtvslo.si/slovenija/erjavec-priznal-da-so-gole-patrie-

resnicnost/65985. Letöltve: 2017.07 .05

. 2007b. „Odbor zadovoljen z vpogledom v dokumente”. RTV Slovenija.

2007. január 24. http://www.rtvslo.si/slovenija/odbor-zadovoljen-z-

vpogledom-v-dokumente/66082. Letöltve: 2017.07.05

Rudman, George. 1996. „Backtracking to Reformulate: Establishing the Bosnian

Federation". International Negotiation 1 (3): 525-45.

https://doi.org/10.1163/157180696X00205.

Sabic, Zlatko, és Charles Bukowski. 2002. „Slovenia and NATO Enlargement:

Experience Gained and Lessons Learned". In Small states in the post-Cold War world: Slovenia and NATO enlargement, szerk. Charles Bukowski és Zlatko Sabic, 145-57. Westport, CT; London: Praeger.

Sarkesian, Sam C. 1981. „Military Professionalism and Civil-Military Relations in the West". International Political Science Review 2 (3): 283-97. https://doi.org/10.1177/019251218100200304.

Schiff, Rebecca L. 1995. „Civil-Military Relations Reconsidered: A Theory of Concordance". Armed Forces \& Society 22 (1): 7-24. https://doi.org/10.1177/0095327x9502200101. . 2009. The Military and Domestic Politics: A Concordance Theory of CivilMilitary Relations. New York: Routledge.

Silber, Laura, és Allan Little. 1996. Jugoszlávia halála. Budapest: Zrínyi.

Simunovic, Pjer. 2015. „Making of an Ally - NATO membership conditionality implemented on Croatia”. Journal of Transatlantic Studies 13 (2): 175-203. https://doi.org/10.1080/14794012.2015.1022372.

Slovenia Times. 2015. „Patria Scandal: From Plans to Equip Army to Verdicts and Retrial". Slovenia Times. 2015. április 23.

http://www.sloveniatimes.com/patria-scandal-from-plans-to-equip-army-toverdicts-and-retrial. Letöltve: 2017.07.05

Slovenian Press Agency. 2006. „Defence Minister Says He Will Step Down if Patria Proves Inferior". Slovenian Press Agency (STA). 2006. június 27.

https://english.sta.si/1065871/defence-minister-says-he-will-step-down-ifpatria-proves-inferior. Letöltve: 2017.07 .05

2008. „Coalition Agreement: Defence Budget in For Cut”. Slovenian Press Agency (STA). 2008. november 18. https://english.sta.si/1302049/coalitionagreement-defence-budget-in-for-cut. Letöltve: 2017.07.05 
2009a. „Vecer Ponders Defence Spending”. Slovenian Press Agency (STA). 2009. február 5. https://english.sta.si/1360989/vecer-ponders-defencespending. Letöltve: 2017.07.05

. 2009b. „Minister Says Army Needs New Faces to Lead Transformation”.

Slovenian Press Agency (STA). 2009. május 11.

https://english.sta.si/1389786/minister-says-army-needs-new-faces-to-leadtransformation Letöltve: 2017.07.05

. 2009c. „Audit Shows Patria Deal Missed Original Goals”. Slovenian Press

Agency (STA). 2009. augusztus 25. https://english.sta.si/1420799/audit-

shows-patria-deal-missed-original-goals. Letöltve: 2017.07.05

. 2009d. „Minister Confirms 25 APCs Only Chassis With No Engine,

Wheels". Slovenian Press Agency (STA). 2009. augusztus 26.

https://english.sta.si/1421065/minister-confirms-25-apcs-only-chassis-withno-engine-wheels. Letöltve: 2017.07.05

. 2009e. ,Zares Wants to Amend or Cancel Patria Deal”. Slovenian Press

Agency (STA). 2009. augusztus 31. https://english.sta.si/1422490/zares-

wants-to-amend-or-cancel-patria-deal. Letöltve: 2017.07.05

. 2011a. „Coalition Mend Differences”. Slovenian Press Agency (STA). 2011.

január 18. https://english.sta.si/1596785/coalition-mend-differences.

Letöltve: 2017.07.05

—. 2011b. „Government Postpones Final Decision on Patria Contract”.

Slovenian Press Agency (STA). 2011. február 3.

https://english.sta.si/1602470/government-postpones-final-decision-on-patriacontract. Letöltve: 2017.07 .05

Soberg, Marius. 2007. „Croatia since 1989: the HDZ and the Politics of Transition”. In Democratic Transition in Croatia. Value Transformation, Education, and Media, szerk. Sabrina Petra Ramet és Davorka Matic, 31-62. College Station: Texas A\&M University Press.

Sowers, Thomas S. 2005. „Beyond the Soldier and the State: Contemporary

Operations and Variance in Principal-Agent Relationships".

Armed Forces \& Society 31 (3): 385-409.

https://doi.org/10.1177/0095327x0503100304.

Spegelj, Martin. 2001. „The First Phase, 1990-1992: the JNA prepares for agression and Croatia for defense". In The war in Croatia and Bosnia-Herzegovina, 1991-1995, szerk. Branka Magas és Ivo Zanic, 14-40. London; Portland:

Frank Cass.

„Splosni dolgorocni program razvoja in opremljanja Slovenske vojske (ReDPRO SV 2001)". 2001. Uradni List Republike Slovenije 2001 (97): 9365.

Stanicic, Mladen. 2003a. „Summary of Security Sector Reform in Croatia”. In Defence and Security Sector Governance and Reform in South East Europe:

Insights and Perspectives. Croatia: A Self-Assessment Study, szerk. Jan Trapans és Philipp H. Fluri, 3-18. Geneva: DCAF Foundation.

. 2004. „Croatia: Defence Reform, Civil-Military Relations and Euro-Atlantic Integration". In Security Sector Governance in the Western Balkans 2004, szerk. Istvan Gyarmati és Scott Vesel, 157-64. Baden-Baden: Nomos Verlag. - 2005. „The Evolution of Civil-Military Relations in South East Europe: The Case of Croatia". In The Evolution of Civil-Military Relations in Southeast Europe, szerk. Philipp H. Fluri, Gustav Gustenau, és Plamen Pantev, 115-30. Heidelberg: Physica Verlag. 
Stanicic, Mladen, és Vladko Cvrtila. 2007. „Security Sector Reform in Croatia”. In Security Sector Governance in the Western Balkans: Self-Assessment Studies on Defence, Intelligence, Police and Border Management Reform, szerk. Anja H. Ebnöther, Philipp H. Fluri, és Predrag Jurekovic, 101-36. Vienna, Geneva.

Stankovic, Slobodan. 1982. „Yugoslav Army's budget comes under fire”. RAD Background Report 262. München: Radio Free Europe / Radio Liberty. . 1983. ,Yugoslav military leaders warn against disunity”. RAD Background Report 270. München: Radio Free Europe / Radio Liberty. . 1984a. „Controversy surrounding Yugoslav Army”. RAD Background Report 66. München: Radio Free Europe / Radio Liberty. . 1984b. ,»Radical changes « suggested by Yugoslav CC in discussion of economic difficulties". RAD Background Report 201. München: Radio Free Europe / Radio Liberty.

Stepan, Alfred. 1971. The military in politics: changing patterns in Brazil. Princeton: Princeton University Press.

„Strategija nacionalne sigurnosti Republike Hrvatske (RH)”. 2002. Narodne Novine 2002 (32): 692.

Sudetic, Charles. 1992. „Historical setting”. In Yugoslavia: a country study, szerk. Glenn E. Curtis, 1-57. Area Handbook Series. Washington, D.C.: Federal Research Division, Library of Congress.

Svajncer, Janez J. 1992. Teritorialna obramba R.S. Ljubljana: Viharnik.

—. 1993. Obranili domovino. Ljubljana: Viharnik.

Svete, Uros. 2011. Interjú: Uros Svete biztonságpolitikai szakértő. Ljubljana, 2011. június 13.

Svete, Uros, és Ljubica Jelusic. 2009. „End of conscription and problems of manning: the case of Slovenian Armed Forces". In Advances in Military Sociology: Essays in Honor of Charles C. Moskos, szerk. Giuseppe Caforio és Manas Chatterji, 3-16. London: Emerald Group Publishing.

Szabó, János. 1998. Modern civil kontroll - elméletek, konfliktusok, modellek. Védelmi Tanulmányok 25. Budapest: Stratégiai és Védelmi Kutatóintézet.

Szilágyi, Imre. 1998. Az önálló és demokratikus Szlovénia létrejötte. Budapest: Teleki László Alapítvány. . 2002a. Sikerek és dilemmák Szlovénia biztonságpolitikájában, 1990-2002. Védelmi Tanulmányok 46. Budapest: Stratégiai Védelmi Kutató Hivatal. 2002b. „Szlovénia és a NATO”. Külügyi Szemle 1 (4): 74-85.

—. 2003. „Horvátország úton a NATO felé”. Budapest: Teleki László Intézet.

Tabak, Igor. 2011. „Prvih trideset mjeseci novog sustava Parlamentarnog nadzora nad obrambenim sektorom u Republici Hrvatskoj". Polemos 14 (2): 83-99.

Tanner, Marcus. 2001. Croatia: A nation forged in war. New Haven: Yale University Press.

Tatalovic, Sinisa. 1996. „Military and Political Aspects of the Croato-Serbian Conflict”. Politicka Misao 33 (5): 166-90. . 2003. „The Parliament and Security Sector”. In Defence and Security Sector Governance and Reform in South East Europe: Insights and Perspectives. Croatia: A Self-Assessment Report, szerk. Philipp H. Fluri és Jan Trapans, 36-52. Geneva: DCAF Foundation. 
2004. „Reform of the Croatian Army in the context of regional security”. In The role of the parliament in security sector reform in the countries of the Western Balkans, szerk. Miroslav Hadzic, 66-76. Belgrade: Center for CivilMilitary Relations.

. 2007. „Croatia and NATO - The public perception of NATO membership”. In Yearbook Sipan 2007, szerk. Lidija Cehulic-Vukadinovic, 111-21. Zagreb: Politicka Kultura.

. 2010. „Utjecaj vanjskih činilaca na razvoj sigurnosne politike Republike Hrvatske". Medunarodne studije 10 (1): 5-21.

. 2011. „Treba li Hrvatskoj nova strategija nacionalne sigurnosti?” Politicke Analize 2 (6): 34-37.

Thomas, Nigel, és Krunoslav Mikulan. 2006. The Yugoslav Wars (I). Slovenia \& Croatia 1991-1995. Oxford: Osprey Publishers.

T-portal.hr. 2017. „Supreme Court quashes verdict in army truck scam”. T-portal.hr. 2017. április 3. https://www.tportal.hr/vijesti/clanak/supreme-court-quashesverdict-in-army-truck-scam-20130403. Letöltve: 2018.03.20.

Tus, Anton. 2001. „The War in Slovenia and Croatia up to the Sarajevo Ceasefire”. In The war in Croatia and Bosnia-Herzegovina, 1991-1995, szerk. Branka Magas és Ivo Zanic, 41-66. London; Portland: Frank Cass.

United Nations Department of Peacekeeping Operations. 2002. Civil-Military Coordination Policy. http://www.refworld.org/pdfid/451ba7624.pdf. Letöltve: 2018.04.05

U.S. Department of State. 2008. „Adriatic Charter Expands to Include New Countries". 2008. https://2001-2009.state.gov/p/eur/rls/or/112762.htm. Letöltve: 2018.04 .05

U.S. Department of the Army. 2006. Civil Affairs Operations. Field Manual No. 305.40 (FM 41-10). Washington, D.C. https://fas.org/irp/doddir/army/fm3-0540.pdf. Letöltve: 2018.04 .05

Ustav Republike Hrvatske. 1990. Narodne Novine 1990 (56): 1092.

Ustava Republike Slovenije. 1991. Uradni List Republike Slovenije 1991 (33): 1373.

Vankovska, Biljana. 1995. „The military in the modern political systems on the former Yugoslav territory". Balkan Forum 3 (3): 207-32. . 2002. „Privatisation of Security and Security Sector Reform in Croatia”. In Security Sector Reform: The Challenges and Opportunities of the Privatisation of Security, szerk. Damian Lilly és Michael von Tangen Page, 55-89. London: International Alert.

Vankovska, Biljana, és Håken Wiberg. 2003. Between Past and Future: CivilMilitary Relations in Post-Communist Balkan States. London; New York: I.B. Tauris.

Vasic, Milos. 1996. „The Yugoslav Army and the post-Yugoslav Armies”. In Yugoslavia and after, szerk. David A. Dyker és Ivan Vejvoda, 116-37. London; New York: Longman.

Vecernji List. 2017. „Kako je posrnuo moćni general Zagorec”. Vecernji List. 2017. április 27. https://www.vecernji.hr/vijesti/kako-je-posrnuo-mocni-generalzagorec-1165620. Letöltve: 2018.04.06.

Vego, Milan. 1993. „The Croatian Army”. Jane’s Intelligence Review, May 1993: 203-10.

Vojna u Sloveniji. Od napadov na JLA do zmage nad JA. Posebna izdaja tednika IN. 1991. Ljubljana: Mednarodno tiskovno sredisce. 
Volten, Peter. 2005. „Croatia”. In The Western Balkan Candidates for NATO Membership and Partnership, szerk. David Greenwood, 43-60. Groningen: Centre for European Security Studies.

Vuga, Janja. 2014. „Safety Bubble versus Risk Awareness: Casualty Aversion among the Slovenian Public". Armed Forces \& Society 40 (2): 357-81. https://doi.org/10.1177/0095327x12465814.

Vukadinovic, Radovan. 2008. „Horvátország a NATO-csatlakozás küszöbén”. In Horvátország NATO-tagsága, szerk. Radovan Vukadinovic, 2-21. Budapest: Geopolitikai Tanács Alapítvány.

Watkins, Amadeo. 2004. „PfP Integration: Croatia, Serbia and Montenegro”. Shrivenam: Conflict Studies Research Centre, Defense Academy of the United Kingdom.

Wells, Richard S. 1996. „The Theory of Concordance in Civil/Military Relations: A Commentary". Armed Forces \& Society 23 (2): 269-75. https://doi.org/10.1177/0095327X9602300208

Wheaton, Kristan J. 2000. „Success! Security Assistance and Its Impact in Croatia, 1995-2000”. The DISAM Journal, sz. Fall 2000: 67-73. http://www.disam.dsca.mil/pubs/v.23_1/wheaton.pdf. Letöltve: 2018.04.09. „Zakon o izmjenama i dopunama Zakona o obrani”. 2007. Narodne Novine 2007 (76): 2403.

Zimmermann, Warren. 1999. Origins of a catastrophe. New York: Times Books.

Zunec, Ozren. 1996. „Democracy in the »Fog of War«: Civil-Military Relations in Croatia". In Civil-Military Relations in the Soviet and Yugoslav Successor States, szerk. Constantine P. Danopoulos és Daniel Zirker, 213-30. Boulder (Colo.): Westview Press.

- 2001. „Operations Flash and Storm”. In The war in Croatia and BosniaHerzegovina, 1991-1995, szerk. Branka Magas és Ivo Zanic, 67-83. London; Portland: Frank Cass.

Zunec, Ozren et al. 2009. „The War in Croatia, 1991-1995”. In Confronting the Yugoslav Controversies: A Scholars' Initiative, szerk. Charles Ingrao és Thomas A. Emmert, 230-70. West Lafayette, IN: Purdue University Press. 